\title{
Water Gas Shift Reaction Catalysis Promoted by Selective Sorption of Carbon Dioxide: Microreactor Experiments
}

\author{
Ramanjaneyulu Katta \\ West Virginia University
}

Follow this and additional works at: https://researchrepository.wvu.edu/etd

\section{Recommended Citation}

Katta, Ramanjaneyulu, "Water Gas Shift Reaction Catalysis Promoted by Selective Sorption of Carbon Dioxide: Microreactor Experiments" (2011). Graduate Theses, Dissertations, and Problem Reports. 4739. https://researchrepository.wvu.edu/etd/4739

This Thesis is protected by copyright and/or related rights. It has been brought to you by the The Research Repository @ WVU with permission from the rights-holder(s). You are free to use this Thesis in any way that is permitted by the copyright and related rights legislation that applies to your use. For other uses you must obtain permission from the rights-holder(s) directly, unless additional rights are indicated by a Creative Commons license in the record and/ or on the work itself. This Thesis has been accepted for inclusion in WVU Graduate Theses, Dissertations, and Problem Reports collection by an authorized administrator of The Research Repository @ WVU. For more information, please contact researchrepository@mail.wvu.edu. 


\title{
Water Gas Shift Reaction Catalysis Promoted by Selective Sorption of Carbon Dioxide: Microreactor Experiments
}

\author{
Ramanjaneyulu Katta \\ Thesis submitted to the College of Engineering and Mineral Resources at \\ West Virginia University \\ In partial fulfillment of the requirements \\ for the degree of \\ Master of Science \\ in \\ Chemical Engineering
}

Dady B. Dadyburjor, PhD, Chair

Edwin L. Kugler, PhD

Charter D. Stinespring, PhD

Todd H. Gardner, PhD

Department of Chemical Engineering

Morgantown, West Virginia

2011

Keywords: WGS reaction, HTS catalyst, kinetics, CaO sorbent, SEWGS reaction, sorption capacity 


\section{Abstract}

\section{Water Gas Shift Reaction Catalysis Promoted by Selective Sorption of Carbon Dioxide: Microreactor Experiments}

\section{Ramanjaneyulu Katta}

Production of hydrogen via the water-gas shift (WGS) reaction normally requires multiple reaction steps followed by $\mathrm{CO}_{2}$ separation. However, in-situ removal of $\mathrm{CO}_{2}$ via the carbonation reaction between $\mathrm{CaO}$ and $\mathrm{CO}_{2}$ provides the opportunity to combine WGS and separation reactions into a single unit. Consequently, the need for heat exchangers between catalyst beds as well as the absorption and stripping units for $\mathrm{CO}_{2}$ removal can be eliminated.

In this study, a commercial high-temperature-shift (HTS) catalyst, $\mathrm{Fe}_{2} \mathrm{O}_{3} / \mathrm{Cr}_{2} \mathrm{O}_{3} / \mathrm{CuO}$ is used. Calcium oxide $(\mathrm{CaO})$ and calcium oxide incorporated with calcium aluminate $\left(\mathrm{Ca}_{12} \mathrm{Al}_{14} \mathrm{O}_{33}\right)$ are used as sorbents for $\mathrm{CO}_{2}$ capture. The $\mathrm{CaO} / \mathrm{Ca}_{12} \mathrm{Al}_{14} \mathrm{O}_{33}$ sorbent is synthesized in $75 / 25$ and $50 / 50$ ratios.

Initially, the performance of HTS catalyst alone is studied. The results indicate that the $\mathrm{CO}$ conversion increases as the temperature and $\mathrm{H}_{2} \mathrm{O} / \mathrm{CO}$ ratio increase. From these experiments, the forward and reverse kinetic parameters are calculated. The activation energy and pre-exponential factor are found to be 79.01 $\mathrm{KJ} / \mathrm{mol}$ and $2.44 \times 10^{3} \mathrm{~mol} / \mathrm{gcatalyst} / \mathrm{sec} / \mathrm{atm}^{2}$ respectively. 
Subsequently, the activity of sorbents towards the WGS reaction is measured. The sorbents exhibit minute activity towards WGS and the CO conversions obtained are negligible.

Finally, the combined shift and carbonation reactions are conducted. Conditions are $500{ }^{\circ} \mathrm{C}$ and 1 atm with a $\mathrm{H}_{2} \mathrm{O} / \mathrm{CO}$ ratio of 2 . Two different modes are used: catalyst and sorbent particles well mixed (sorption-enhanced WGS, SEWGS), and catalyst and sorbent particles separated by quartz chips. The SEWGS will proceeds in three phases: sorbent enhancement, sorbent breakthrough, and postbreakthrough. For the HTS-CaO, no $\mathrm{CO}_{2}$ is detected in the reactor outlet till after the $6^{\text {th }}$ minute. This is the sorbent enhancement period. For $\mathrm{HTS}-\mathrm{CaO} / \mathrm{Ca}_{12} \mathrm{Al}_{14} \mathrm{O}_{33}$ (75/25), the sorbent enhancement period lasts for 5 mins. For $\mathrm{HTS}-\mathrm{CaO} / \mathrm{Ca}_{12} \mathrm{Al}_{14} \mathrm{O}_{33}$ (50/50), this period lasts for only 4 mins. The sorbents $\mathrm{CaO}, \mathrm{CaO} / \mathrm{Ca}_{12} \mathrm{Al}_{14} \mathrm{O}_{33}$ (75/25), and $\mathrm{CaO} / \mathrm{Ca}_{12} \mathrm{Al}_{14} \mathrm{O}_{33}(75 / 25)$ reach their post-breakthrough period at approximately 35, 29, and 20 minutes respectively. The sorbents $\mathrm{CaO}$ and $\mathrm{CaO} / \mathrm{Ca}_{12} \mathrm{Al}_{14} \mathrm{O}_{33}(75 / 25)$ show better performance in the SEWGS than does the $\mathrm{CaO} / \mathrm{Ca}_{12} \mathrm{Al}_{14} \mathrm{O}_{33}(50 / 50)$ sorbent.

The presence of any sorbent $\left(\mathrm{CaO}, \mathrm{CaO} / \mathrm{Ca}_{12} \mathrm{Al}_{14} \mathrm{O}_{33}\right.$ whether $75 / 25$ wt \% or $50 / 50 \mathrm{wt} \%$ ) in the reactor as a separate bed does not affect the CO conversion, and the values obtained are same as that of HTS catalyst alone. The $\mathrm{CaO}$, $\mathrm{CaO} / \mathrm{Ca}_{12} \mathrm{Al}_{14} \mathrm{O}_{33}(75 / 25)$, and $\mathrm{CaO} / \mathrm{Ca}_{12} \mathrm{Al}_{14} \mathrm{O}_{33}$ (50/50) adsorb all the $\mathrm{CO}_{2}$ formed for the first 7, 6, and 3 mins respectively, and finally reach their post-breakthrough period at approximately 45,36 , and 28 minutes respectively. 
Sorption capacities are calculated based on both the total weight and on a $\mathrm{CaO}$ basis. The $\mathrm{CO}_{2}$ sorption capacities of $\mathrm{CaO}, \mathrm{CaO} / \mathrm{Ca}_{12} \mathrm{Al}_{14} \mathrm{O}_{33}(75 / 25)$, and $\mathrm{CaO} / \mathrm{Ca}_{12} \mathrm{Al}_{14} \mathrm{O}_{33}(50 / 50)$ sorbents on the total weight basis in the separated mode are $8.27,6.33$, and $3.92 \mathrm{~mol} / \mathrm{Kg}$ respectively. In the mixed mode, the corresponding values are $8.54,6.36$, and $4.16 \mathrm{~mol} / \mathrm{Kg}$ respectively. The sorption capacity is found to remain relatively constant for each sorbent in the two different modes. On the $\mathrm{CaO}$ basis, the $\mathrm{CO}_{2}$ capture capacities of $\mathrm{CaO} / \mathrm{Ca}_{12} \mathrm{Al}_{14} \mathrm{O}_{33} \quad(75 / 25)$ and $\mathrm{CaO} / \mathrm{Ca}_{12} \mathrm{Al}_{14} \mathrm{O}_{33}(50 / 50)$ in the separated mode are 8.43 and $7.84 \mathrm{~mol} / \mathrm{Kg}$ respectively. In the combined mode, the corresponding values are $8.48,8.31 \mathrm{~mol} / \mathrm{Kg}$ respectively. Hence, the $\mathrm{CO}_{2}$ capture capacities of all the sorbents are found to be approximately the same on the $\mathrm{CaO}$ basis. From these results, it is concluded that the calcium aluminate $\left(\mathrm{Ca}_{12} \mathrm{Al}_{14} \mathrm{O}_{33}\right)$ acts as a binder only and does not necessarily participate in the carbonation reaction. 
Dedicated to my uncle

Late Polineni Yellamandarao. 


\section{ACKNOWLEDGEMENT}

I would like to express my sincere gratitude for my advisors Dr. Dady B. Dadyburjor and Dr. Edwin L. Kugler for their guidance and support during my research and study at West Virginia University. I would like to thank Dr. Charter D. Stinespring and Dr. Todd. $\mathrm{H}$ Gardner, for their encouragement and valuable suggestions.

I would like to thank Mr. Liviu Magean and Ms. Gabriela Perhinschi, for their continuous support in catalyst characterization. I am grateful to Linda Rogers and Bonita Helmick for their help in completing my graduate requirements. All my lab buddies made it a convivial place to work. My deepest gratitude to my fellow lab mates, Dr. Guggilla, Dr. Kababji, Ashish, Mayuri, Soumya, Avinash, and Josh for their friendship and concern. In particular, I would like to thank Dr. Guggilla and Ashish for their help during the experimental setup.

My deepest gratitude goes to my parents and grandparents for their unflagging love and support throughout my life. I am indebted to my uncle, late Yellamanda Rao Polineni, for his care and love. Also I thank my friends, Chandra, Prathu, Pradeep, Phani, Rajesh, Srinath, Chowdary, Sajja, and Chintala. I would like to thank my best friend, Santu for her immense moral support, care, time and love. Thank you for being with me at all the times and for always making sure that things ran smoothly for me.

Last and but not least, Thanks to God for my life through all the tests in the past seven years. You have made my life more bountiful. May your name be exalted, honored and glorified. 


\section{Table of Contents}

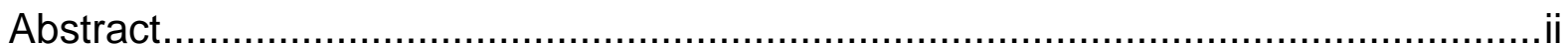

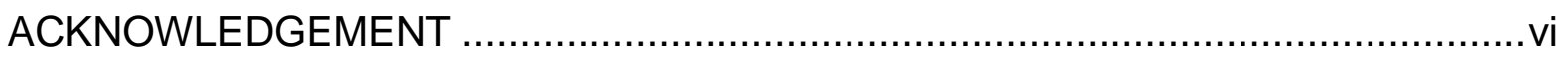

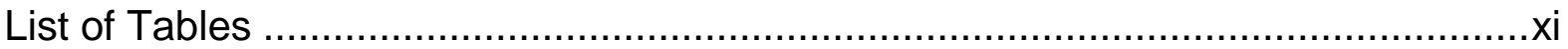

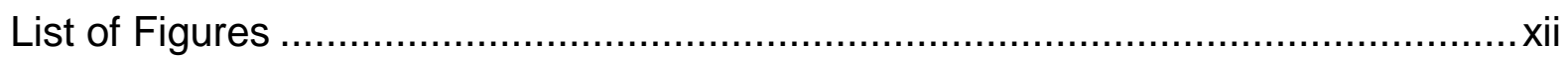

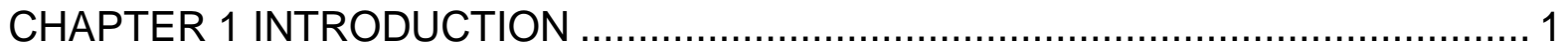

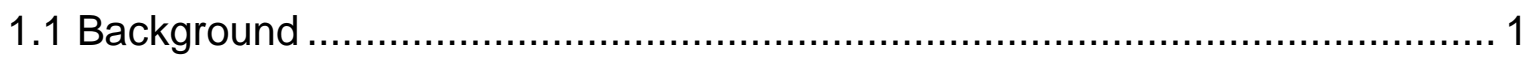

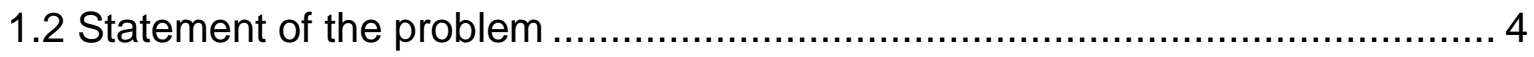

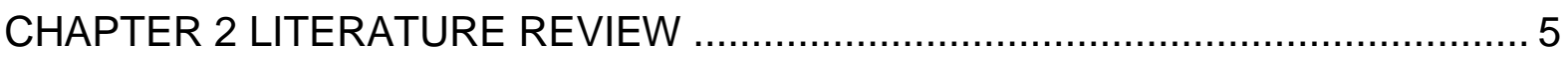

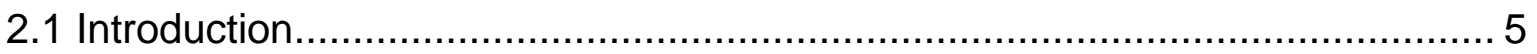

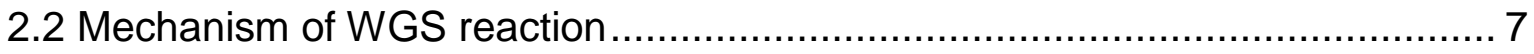

2.3 HTS and LTS catalysts for WGS reaction ............................................ 8

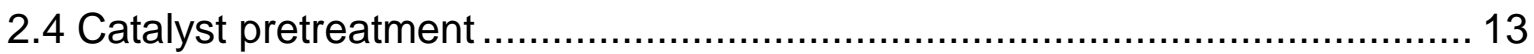

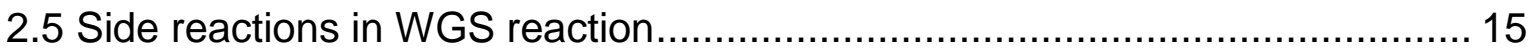

2.6 Carbon dioxide separation techniques ….............................................. 16

2.7 Reaction-based systems for $\mathrm{CO}_{2}$ removal................................................ 19

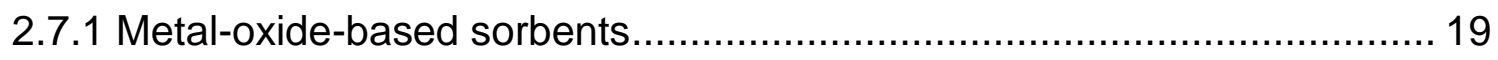

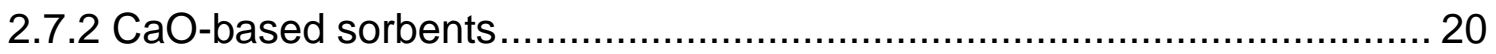

2.7.3 Mechanism of carbonation of $\mathrm{CaO}$-based sorbents ............................... 22

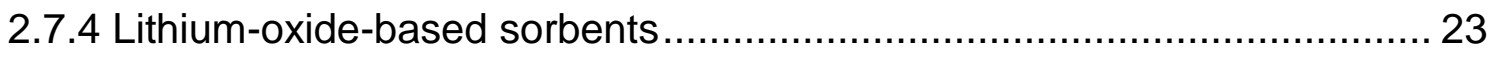

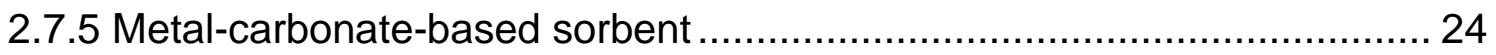

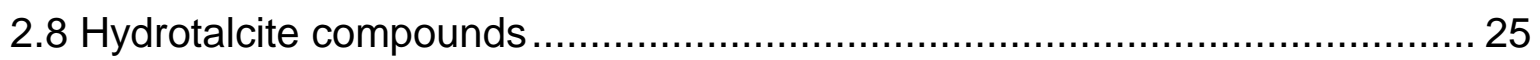

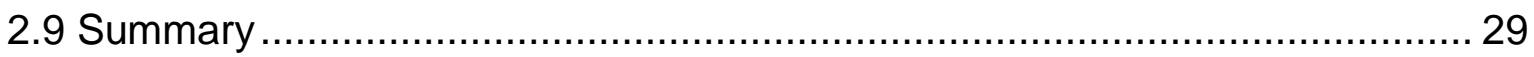




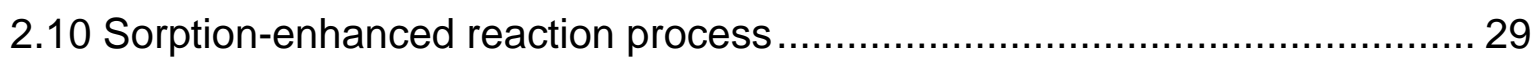

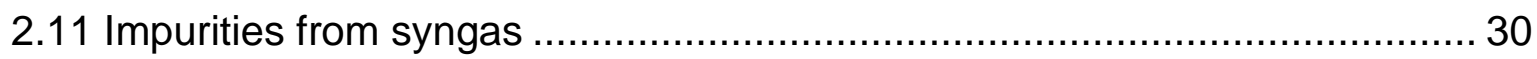

CHAPTER 3 EXPERIMENTAL SETUP AND PROCEDURE ................................ 34

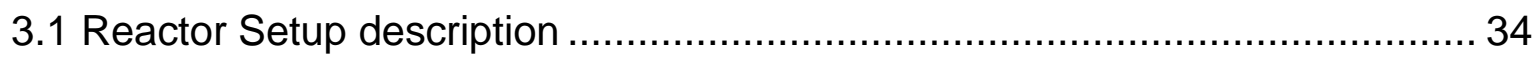

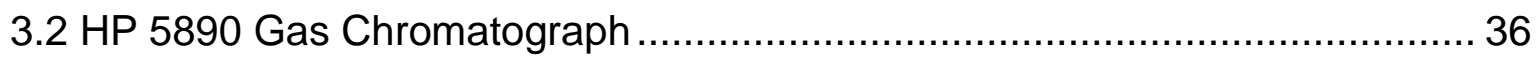

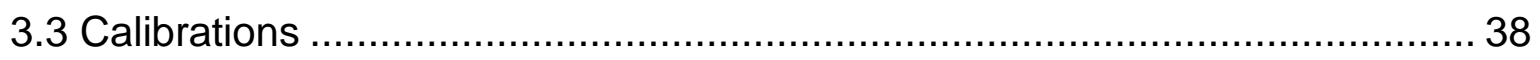

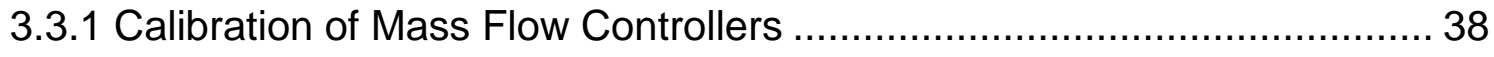

3.3.2 Calibration of HP5890 Gas Chromatograph ......................................... 38

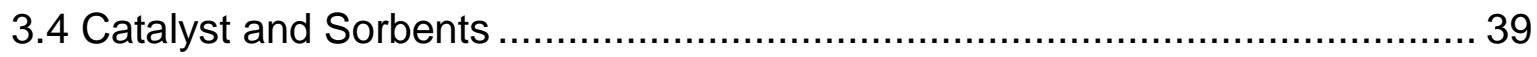

3.4.1 Preparation of $\mathrm{CaO} / \mathrm{Ca}_{12} \mathrm{Al}_{14} \mathrm{O}_{33}$ sorbent in various ratios...................... 39

3.5 Catalyst and sorbent characterization .................................................. 41

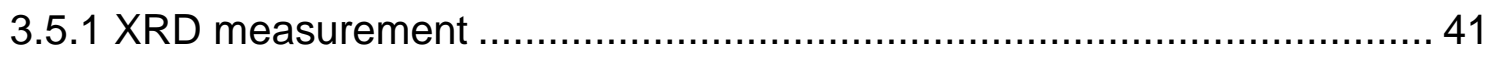

3.5.2 Scanning electron microscopy ................................................... 47

3.5.3 Brunauer-Emmett-Teller (BET) Surface Area Measurement .................. 47

3.6 Pelletization of HTS catalyst and sorbents .............................................. 49

3.7 Pretreatment of the $\mathrm{HTS}\left(\mathrm{Fe}_{2} \mathrm{O}_{3} / \mathrm{Cr}_{2} \mathrm{O}_{3} / \mathrm{CuO}\right)$ catalyst and sorbents ............. 49

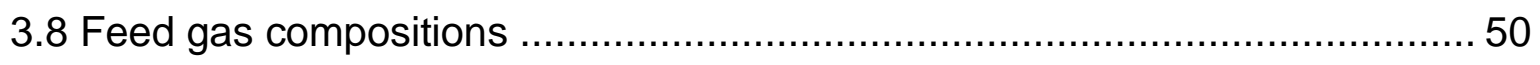

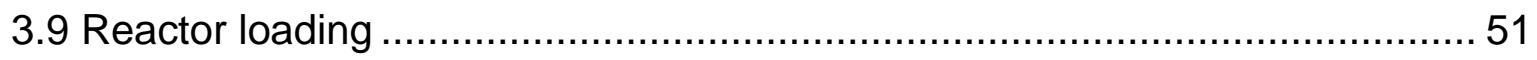

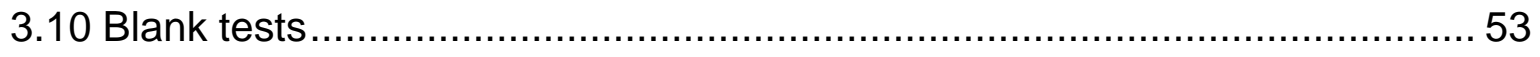

3.11 Study of catalytic activity of sorbents towards WGS reaction ...................... 53

3.13 Combined WGS and carbonation reactions in two different modes ............. 54

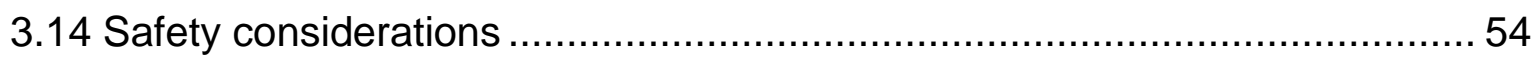

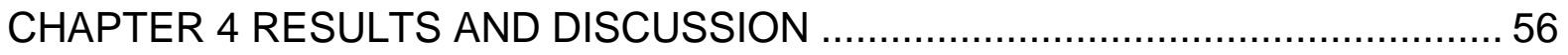




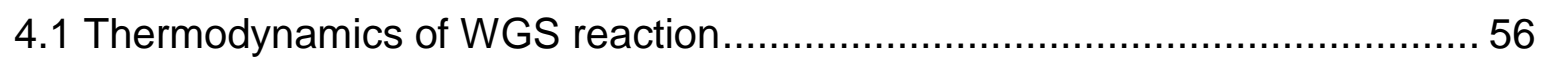

4.2 Effect of the $\mathrm{H}_{2} \mathrm{O} / \mathrm{CO}$ ratio on equilibrium $\mathrm{CO}$ conversion $\left(\mathrm{X}_{\mathrm{e}}\right) \ldots \ldots \ldots \ldots \ldots \ldots \ldots . . . . . . . . .56$

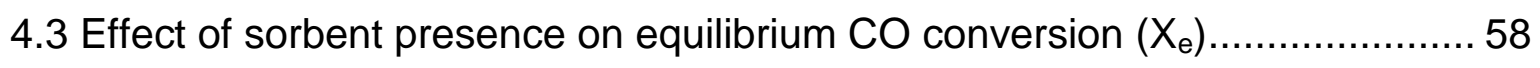

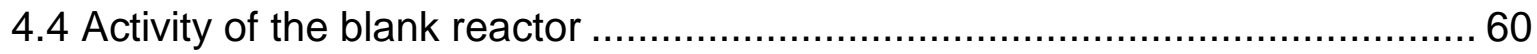

4.5 Thermodynamics and kinetics of the WGS reaction................................... 62

4.6 Effect of the reaction temperature on $\mathrm{CO}$ conversion for various ................... 64

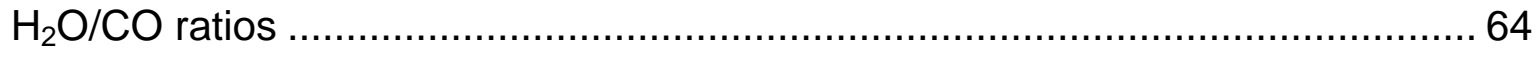

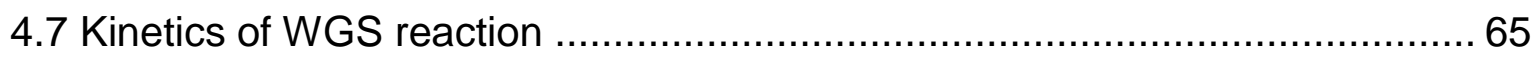

4.8 Study of sorbent activity for WGS reaction without catalyst..........................69

4.9 Combined WGS and carbonation reactions with HTS catalyst-sorbent system 70

4.9.1 HTS catalyst and sorbent mixture .................................................. 71

4.9.2 HTS catalyst and sorbent separated with chips ….............................. 79

4.9.3 Comparison of products with varying reactor contents …..................... 85

4.10 Comparison of adsorption capacity of different sorbents for

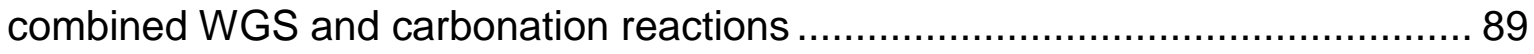

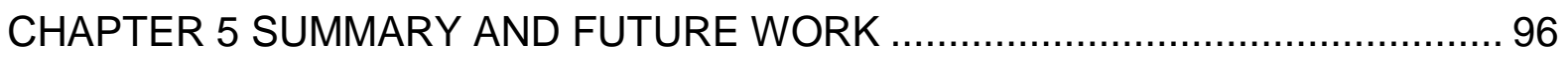

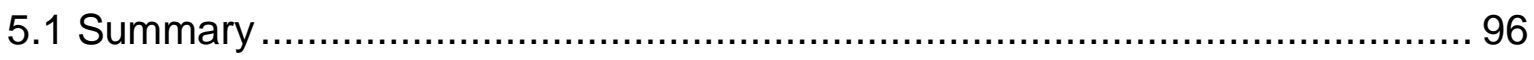

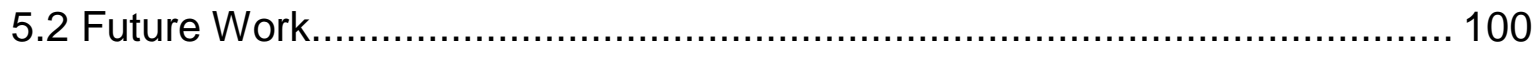

APPENDIX A: Mass Flow Controller calibration curves ...................................... 103

APPENDIX B: Gas Chromatograph operating conditions …............................... 106

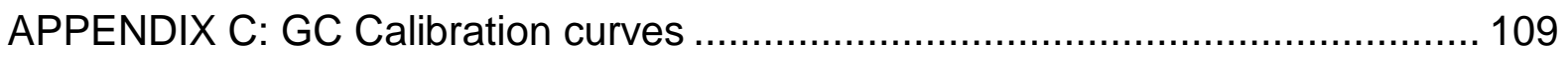

APPENDIX D: Calculation procedure for Relative Response Factors .................. 117 
APPENDIX E: Calculation procedure for equilibrium conversions $\left(\mathrm{X}_{\mathrm{e}}\right)$ of WGS reaction

APPENDIX F: Calculation procedure for effect of sorbent presence on equilibrium CO conversion $\left(X_{e}\right)$ 120

APPENDIX G: Calculation procedure for preparation of $\mathrm{CaO} / \mathrm{Ca}_{12} \mathrm{Al}_{14} \mathrm{O}_{33}$ sorbent in various ratios

APPENDIX H: Calculation procedure for determination of kinetic parameters of WGS

reaction . 124

APPENDIX I: Calculation procedure for $\mathrm{CO}_{2}$ sorption for $\mathrm{CaO} / \mathrm{Ca}_{12} \mathrm{Al}_{14} \mathrm{O}_{33}(75 / 25 \mathrm{wt}$ $\%)$ and catalyst separated with chips. 127

References 133 


\section{List of Tables}

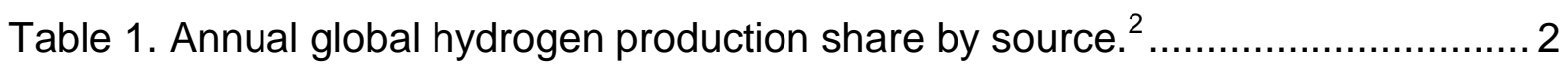

Table 2. Comparison of various hydrogen production methods. ${ }^{1,2,4,5} \ldots \ldots \ldots \ldots \ldots \ldots . . . . . . . .3$

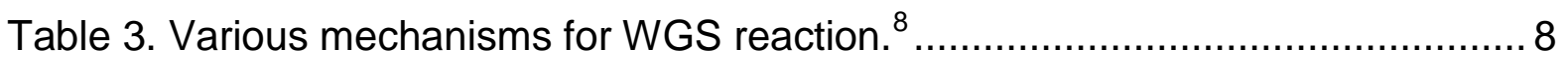

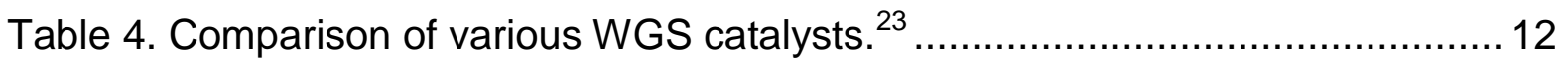

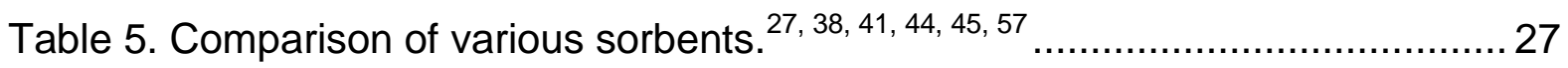

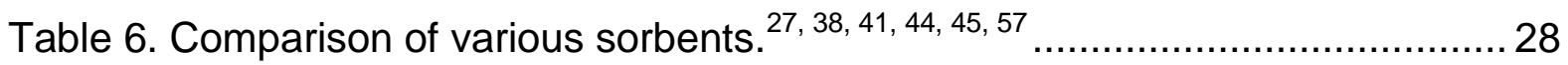

Table 7. Synthesis gas composition (volume \%) generated by different gasifiers. ${ }^{54} 31$

Table 8. Contaminants from syngas and their potential effects. ${ }^{49,50} \ldots \ldots \ldots \ldots \ldots \ldots \ldots . . . . . . . . . . .32$

Table 9. The WGS activities of various catalysts in the presence of $\mathrm{H}_{2} \mathrm{~S}^{56}{ }^{56 \ldots \ldots \ldots . . . . .33}$

Table 10. MFC Calibration equations for gases used in WGS reaction ................... 38

Table 11. Morphological properties of HTS catalyst............................................... 48

Table 12. Forward $\left(\mathrm{k}_{\mathrm{f}}\right)$ and reverse $\left(\mathrm{k}_{\mathrm{r}}\right)$ reaction constants of WGS reaction at

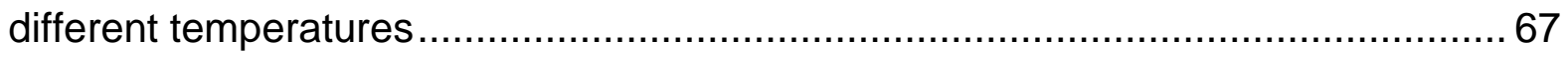

Table 13. Arrhenius parameters for the WGS reaction over various HTS catalysts. 68

Table 14. Capacity (weight basis and $\mathrm{CaO}$ basis), pre-breakthrough time, and post-

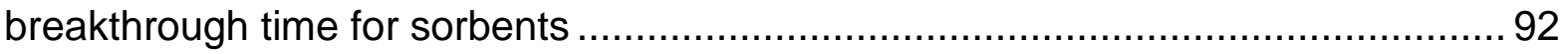

Table 15. Comparison with literature values ...................................................... 93

Table 16. Average slopes of calibration curves of TCD gases.............................111

Table 17. Relative response factors of gases used for WGS reaction ................... 118

Table 18. Moles of $\mathrm{CO}_{2}$ adsorbed and corresponding time ............................. 128

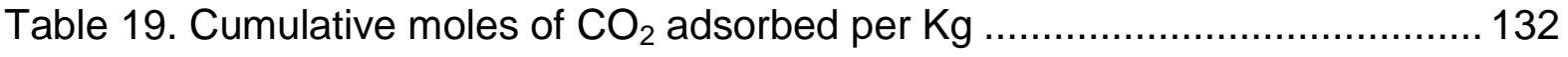




\section{List of Figures}

Figure 1. Equilibrium constant vs temperature for WGS reaction .................................. 6

Figure 2. Schematic diagram of experimental setup for WGS reaction. ..................... 35

Figure 3. Schematic flow diagram of two-position six-port external volume sample

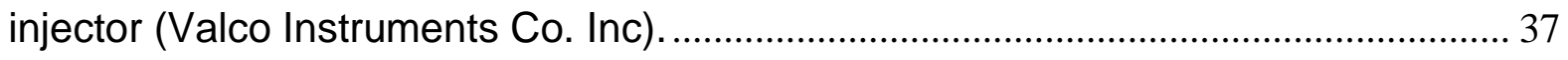

Figure 4. XRD pattern of HTS $\left(\mathrm{Fe}_{2} \mathrm{O}_{3} / \mathrm{Cr}_{2} \mathrm{O}_{3} / \mathrm{CuO}\right)$ catalyst........................................ 43

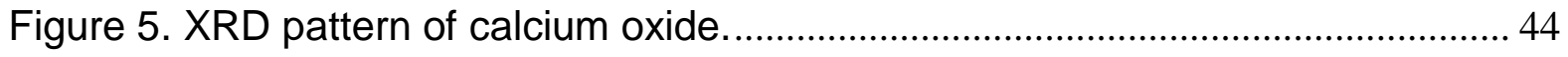

Figure 6. XRD pattern of $\mathrm{CaO} / \mathrm{Ca}_{12} \mathrm{Al}_{14} \mathrm{O}_{33}(50 / 50$ wt \%) sorbent. .............................. 45

Figure 7. XRD pattern of $\mathrm{CaO} / \mathrm{Ca}_{12} \mathrm{Al}_{14} \mathrm{O}_{33}(75 / 25$ wt \%) sorbent. ............................... 46

Figure 8. SEM image of $\mathrm{HTS}\left(\mathrm{Fe}_{2} \mathrm{O}_{3} / \mathrm{Cr}_{2} \mathrm{O}_{3} / \mathrm{CuO}\right)$ catalyst. ........................................ 48

Figure 9. EDS spectrum of $\mathrm{HTS}\left(\mathrm{Fe}_{2} \mathrm{O}_{3} / \mathrm{Cr}_{2} \mathrm{O}_{3} / \mathrm{CuO}\right)$ catalyst. .................................... 49

Figure 10. Schematic diagram of reactor with (1) HTS catalyst and sorbent mixture,

(2) HTS catalyst and sorbent separated with chips. .................................................. 52

Figure 11. Effect of temperature on equilibrium constant $\left(K_{e}\right)$ of WGS reaction. ...... 57

Figure 12. Effect of inlet $\mathrm{H}_{2} \mathrm{O} / \mathrm{CO}$ ratio on $\mathrm{CO}$ conversion at thermodynamic.............58

Figure 13. Effect of $\mathrm{CO}_{2}$ removal on equilibrium $\mathrm{CO}$ conversion of WGS reaction at

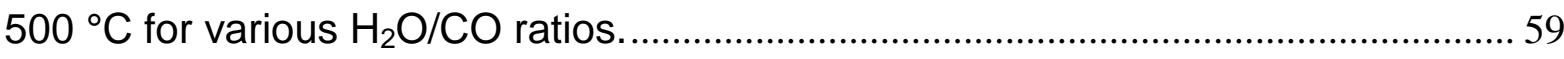

Figure 14. Effect of reaction temperatures on the activity of the blank reactor for WGS reaction (Total pressure: $1 \mathrm{~atm}, \mathrm{H}_{2} \mathrm{O} / \mathrm{CO}: 2,22 \% \mathrm{CO}$, total flow: $200 \mathrm{sccm}$ ). 61 Figure 15. Formation of $\mathrm{H}_{2}$ gas in the blank reactor during the WGS reaction at different temperatures $\left(550-600{ }^{\circ} \mathrm{C}\right)$ (Total pressure: 1 atm, $\mathrm{H}_{2} \mathrm{O} / \mathrm{CO}: 2,22 \% \mathrm{CO}$, total flow: $200 \mathrm{sccm}$ ) 
Figure 16. Effect of reaction temperature on the CO conversion $(0.25 \mathrm{~g}$ of HTS catalyst, P: 1 atm, $22.2 \% \mathrm{CO}, \mathrm{H}_{2} \mathrm{O} / \mathrm{CO}: 2$, total flow: $200 \mathrm{sccm}$ ).

Figure 17. Comparison of equilibrium and experimental CO conversions for WGS reaction in the temperature range of $350-600{ }^{\circ} \mathrm{C}(0.25 \mathrm{~g}$ of HTS catalyst, $22.2 \% \mathrm{CO}$, $\mathrm{P}: 1 \mathrm{~atm}, \mathrm{H}_{2} \mathrm{O} / \mathrm{CO}: 2$, total flow: $200 \mathrm{sccm}$ ). 64

Figure 18. Effect of $\mathrm{H}_{2} \mathrm{O} / \mathrm{CO}$ ratio on $\mathrm{CO}$ conversion for various temperatures $(0.25 \mathrm{~g}$ of HTS catalyst, $22.2 \% \mathrm{CO}, \mathrm{H}_{2} \mathrm{O} / \mathrm{CO}: 1,2, \mathrm{P}: 1 \mathrm{~atm}$, total flow: $200 \mathrm{sccm}$ ). 65

Figure 19. Arrhenius plot for WGS reaction (T: $350-550^{\circ} \mathrm{C}$, catalyst weight: $0.2 \mathrm{~g}, 22$ $\left.\% \mathrm{CO}, \mathrm{H}_{2} \mathrm{O} / \mathrm{CO}: 2, \mathrm{P}: 1 \mathrm{~atm}\right)$. 68

Figure 20. Catalytic activity of sorbents towards WGS reaction $\left(\mathrm{T}: 500{ }^{\circ} \mathrm{C}\right.$, sorbent: $\mathrm{CaO} / \mathrm{Ca}_{12} \mathrm{Al}_{14} \mathrm{O}_{33}(75 / 25$ and 50/50 wt \%), sorbent weight: $2.5 \mathrm{~g}$, Pressure: $1 \mathrm{~atm}) .69$ Figure 21 . Formation of hydrogen during WGS reaction over sorbents $\left(\mathrm{T}: 500{ }^{\circ} \mathrm{C}\right.$, sorbents: $\mathrm{CaO} / \mathrm{Ca}_{12} \mathrm{Al}_{14} \mathrm{O}_{33} 75 / 25$ wt \% and $\mathrm{CaO} / \mathrm{Ca}_{12} \mathrm{Al}_{14} \mathrm{O}_{33} 50 / 50$ wt \%, sorbent weight: $2.5 \mathrm{~g}$, Pressure: $1 \mathrm{~atm})$. 70

Figure 22. Profiles of product gases for sorption-enhanced WGS reaction over HTS$\mathrm{CaO}$ sorbent system $\left(\mathrm{T}: 500{ }^{\circ} \mathrm{C}\right.$, total flow: $380 \mathrm{sccm}, \mathrm{H}_{2} \mathrm{O} / \mathrm{CO}: 2, \mathrm{CO}: 17.54 \%$, He: $\left.0.92 \%, \operatorname{Ar}: 46.81 \%, \mathrm{H}_{2} \mathrm{O}: 34.67 \%\right)$ 72

Figure 23. Profiles of product gases for SEWGS reaction over HTS catalyst$\mathrm{CaO} / \mathrm{Ca}_{12} \mathrm{Al}_{14} \mathrm{O}_{33}\left(75 / 25\right.$ wt \%) sorbent system ( $\mathrm{T}: 500{ }^{\circ} \mathrm{C}$, total flow: $380 \mathrm{sccm}$, $\mathrm{H}_{2} \mathrm{O} / \mathrm{CO}: 2$, CO: $17.54 \%$, He: $0.92 \%$, Ar: $\left.46.81 \%, \mathrm{H}_{2} \mathrm{O}: 34.67 \%\right)$. 73

Figure 24. Profiles of product gases for SEWGS reaction over HTS catalyst$\mathrm{CaO} / \mathrm{Ca}_{12} \mathrm{Al}_{14} \mathrm{O}_{33}(50 / 50 \mathrm{wt} \%)$ sorbent system ( $\mathrm{T}: 500{ }^{\circ} \mathrm{C}$, total flow: $380 \mathrm{sccm}$, $\mathrm{H}_{2} \mathrm{O} / \mathrm{CO}: 2$, CO: $17.54 \%$, He: $0.919 \%$, Ar: $\left.46.808 \%, \mathrm{H}_{2} \mathrm{O}: 34.67 \%\right)$. 74 
Figure 25. Comparison of CO outlet molar flow rates for WGS reaction over HTS catalyst-CaO sorbent mixture and HTS catalyst alone (Catalyst: $\mathrm{Fe}_{2} \mathrm{O}_{3} / \mathrm{Cr}_{2} \mathrm{O}_{3} / \mathrm{CuO}$,

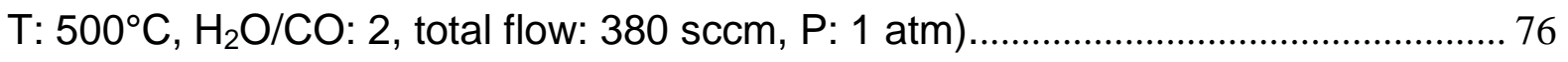
Figure 26. Comparison of $\mathrm{CO}$ outlet molar flow rates for WGS reaction over HTS catalyst- $\mathrm{CaO} / \mathrm{Ca}_{12} \mathrm{Al}_{14} \mathrm{O}_{33}(75 / 25$ wt \%) sorbent mixture and $\mathrm{HTS}$ catalyst alone. (Catalyst: $\mathrm{Fe}_{2} \mathrm{O}_{3} / \mathrm{Cr}_{2} \mathrm{O}_{3} / \mathrm{CuO}, \mathrm{T}: 500^{\circ} \mathrm{C}, \mathrm{H}_{2} \mathrm{O} / \mathrm{CO}: 2$, total flow: $380 \mathrm{sccm}, \mathrm{P}: 1 \mathrm{~atm}$ ). 76 Figure 27. Comparison of $\mathrm{CO}$ outlet molar flow rates for WGS reaction over HTS catalyst- $\mathrm{CaO} / \mathrm{Ca}_{12} \mathrm{Al}_{14} \mathrm{O}_{33}$ (50/50 wt \%) sorbent mixture and $\mathrm{HTS}$ catalyst alone. (Catalyst: $\mathrm{Fe}_{2} \mathrm{O}_{3} / \mathrm{Cr}_{2} \mathrm{O}_{3} / \mathrm{CuO}, \mathrm{T}: 500^{\circ} \mathrm{C}, \mathrm{H}_{2} \mathrm{O} / \mathrm{CO}: 2$, total flow: 380 sccm, P: 1 atm). 77 Figure 28. Comparison of $\mathrm{CO}_{2}$ outlet molar flow rates for WGS reaction over HTS catalyst-CaO sorbent mixture and HTS catalyst alone (Catalyst: $\mathrm{Fe}_{2} \mathrm{O}_{3} / \mathrm{Cr}_{2} \mathrm{O}_{3} / \mathrm{CuO}$,

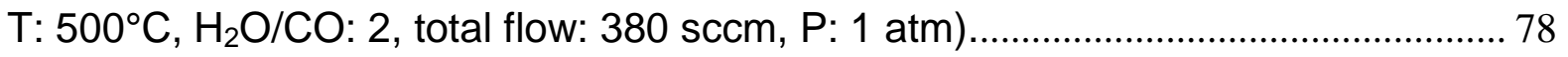

Figure 29. Comparison of $\mathrm{CO}_{2}$ outlet molar flow rates for WGS reaction over HTS catalyst- $\mathrm{CaO} / \mathrm{Ca}_{12} \mathrm{Al}_{14} \mathrm{O}_{33}(75 / 25 \mathrm{wt} \%)$ sorbent mixture and $\mathrm{HTS}$ catalyst alone. (Catalyst: $\mathrm{Fe}_{2} \mathrm{O}_{3} / \mathrm{Cr}_{2} \mathrm{O}_{3} / \mathrm{CuO}, \mathrm{T}: 500^{\circ} \mathrm{C}, \mathrm{H}_{2} \mathrm{O} / \mathrm{CO}: 2$, total flow: $380 \mathrm{sccm}, \mathrm{P}: 1 \mathrm{~atm}$ ). 78 Figure 30. Comparison of $\mathrm{CO}_{2}$ outlet molar flow rates for WGS reaction over HTS catalyst- $\mathrm{CaO} / \mathrm{Ca}_{12} \mathrm{Al}_{14} \mathrm{O}_{33}(50 / 50$ wt \%) sorbent mixture and $\mathrm{HTS}$ catalyst alone. (Catalyst: $\mathrm{Fe}_{2} \mathrm{O}_{3} / \mathrm{Cr}_{2} \mathrm{O}_{3} / \mathrm{CuO}, \mathrm{T}: 500^{\circ} \mathrm{C}, \mathrm{H}_{2} \mathrm{O} / \mathrm{CO}: 2$, total flow: $380 \mathrm{sccm}, \mathrm{P}: 1 \mathrm{~atm}$ ). 79 Figure 31. Comparison of $\mathrm{CO}$ outlet molar flow rates for WGS reaction during the HTS catalyst and $\mathrm{CaO}$ sorbent separated with chips and HTS catalyst alone (Catalyst: $\mathrm{Fe}_{2} \mathrm{O}_{3} / \mathrm{Cr}_{2} \mathrm{O}_{3} / \mathrm{CuO}$, sorbent: $\mathrm{CaO}, \mathrm{T}: 500^{\circ} \mathrm{C}, \mathrm{H}_{2} \mathrm{O} / \mathrm{CO}$ : 2, total flow: 380 sccm, P: $1 \mathrm{~atm})$. 80 
Figure 32. Comparison of $\mathrm{CO}$ outlet molar flow rates for WGS reaction during the HTS catalyst and $\mathrm{CaO} / \mathrm{Ca}_{12} \mathrm{Al}_{14} \mathrm{O}_{33}(75 / 25$ wt \%) sorbent separated with chips and HTS catalyst alone (Catalyst: $\mathrm{Fe}_{2} \mathrm{O}_{3} / \mathrm{Cr}_{2} \mathrm{O}_{3} / \mathrm{CuO}, \mathrm{T}: 500^{\circ} \mathrm{C}, \mathrm{H}_{2} \mathrm{O} / \mathrm{CO}: 2$, total flow: 380 sccm, P: 1 atm). 81

Figure 33. Comparison of $\mathrm{CO}$ outlet molar flow rates for WGS reaction during the HTS catalyst and $\mathrm{CaO} / \mathrm{Ca}_{12} \mathrm{Al}_{14} \mathrm{O}_{33}(50 / 50$ wt \%) sorbent separated with chips and HTS catalyst alone (Catalyst: $\mathrm{Fe}_{2} \mathrm{O}_{3} / \mathrm{Cr}_{2} \mathrm{O}_{3} / \mathrm{CuO}$, T: $500^{\circ} \mathrm{C}, \mathrm{H}_{2} \mathrm{O} / \mathrm{CO}$ : 2, total flow: 380 sccm, P: $1 \mathrm{~atm})$ 81

Figure 34. Profiles of product gases for HTS catalyst and $\mathrm{CaO}$ sorbent separated with chips (T: $500{ }^{\circ} \mathrm{C}$, total flow: $380 \mathrm{sccm}, \mathrm{H}_{2} \mathrm{O} / \mathrm{CO}: 2$, CO: $17.54 \%$, He: $0.92 \%$, Ar: $\left.46.81 \%, \mathrm{H}_{2} \mathrm{O}: 34.67 \%\right)$ 83

Figure 35. Profiles of product gases for $\mathrm{HTS}$ catalyst and $\mathrm{CaO} / \mathrm{Ca}_{12} \mathrm{Al}_{14} \mathrm{O}_{33}(75 / 25 \mathrm{wt}$ \%) sorbent separated with chips ( $\mathrm{T}: 500^{\circ} \mathrm{C}$, total flow: $380 \mathrm{sccm}, \mathrm{H}_{2} \mathrm{O} / \mathrm{CO}: 2, \mathrm{CO}$ : $17.54 \%$, He: $0.92 \%$, Ar: $\left.46.81 \%, \mathrm{H}_{2} \mathrm{O}: 34.67 \%\right)$ 84

Figure 36. Profiles of product gases for $\mathrm{HTS}$ catalyst and $\mathrm{CaO} / \mathrm{Ca}_{12} \mathrm{Al}_{14} \mathrm{O}_{33}(50 / 50 \mathrm{wt}$ $\%$ ) sorbent separated with chips ( $\mathrm{T}: 500{ }^{\circ} \mathrm{C}$, total flow: $380 \mathrm{sccm}, \mathrm{H}_{2} \mathrm{O} / \mathrm{CO}: 2, \mathrm{CO}$ : $17.54 \%$, He: $0.92 \%$, Ar: $\left.46.81 \%, \mathrm{H}_{2} \mathrm{O}: 34.67 \%\right)$. 85

Figure 37. Profiles of $\mathrm{CO}_{2}$ for WGS reaction over $\mathrm{HTS}-\mathrm{CaO}$ in both modes and HTS

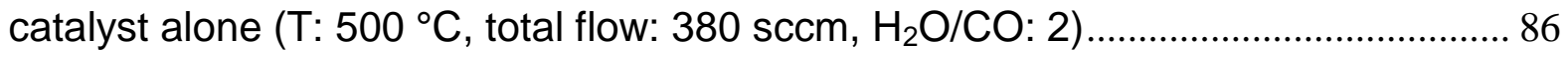

Figure 38. Profiles of $\mathrm{CO}_{2}$ for WGS reaction over $\mathrm{HTS}-\mathrm{CaO} / \mathrm{Ca}_{12} \mathrm{Al}_{14} \mathrm{O}_{33}(75 / 25 \mathrm{wt}$ $\%$ ) in both modes and HTS catalyst alone (T: $500{ }^{\circ} \mathrm{C}$, total flow: $380 \mathrm{sccm}, \mathrm{H}_{2} \mathrm{O} / \mathrm{CO}$ : 2). 87 
Figure 39. Profiles of $\mathrm{CO}_{2}$ for WGS reaction over $\mathrm{HTS}-\mathrm{CaO} / \mathrm{Ca}_{12} \mathrm{Al}_{14} \mathrm{O}_{33}(50 / 50 \mathrm{wt}$ $\%$ ) in both modes and HTS catalyst alone (T: $500{ }^{\circ} \mathrm{C}$, total flow: $380 \mathrm{sccm}, \mathrm{H}_{2} \mathrm{O} / \mathrm{CO}$ :

2).

Figure 40. Profiles of $\mathrm{H}_{2}$ for WGS reaction over HTS-CaO in both modes and HTS catalyst alone ( $\mathrm{T}: 500{ }^{\circ} \mathrm{C}$, total flow: $\left.380 \mathrm{sccm}, \mathrm{H}_{2} \mathrm{O} / \mathrm{CO}: 2\right)$ 88

Figure 41. Profiles of $\mathrm{H}_{2}$ for WGS reaction over $\mathrm{HTS}-\mathrm{CaO} / \mathrm{Ca}_{12} \mathrm{Al}_{14} \mathrm{O}_{33}(75 / 25)$ in both modes and HTS catalyst alone (T: $500^{\circ} \mathrm{C}$, total flow: $\left.380 \mathrm{sccm}, \mathrm{H}_{2} \mathrm{O} / \mathrm{CO}: 2\right) . .88$ Figure 42. Profiles of $\mathrm{H}_{2}$ for WGS reaction over $\mathrm{HTS}-\mathrm{CaO} / \mathrm{Ca}_{12} \mathrm{Al}_{14} \mathrm{O}_{33}(50 / 50)$ in both modes and HTS catalyst alone (T: $500^{\circ} \mathrm{C}$, total flow: $\left.380 \mathrm{sccm}, \mathrm{H}_{2} \mathrm{O} / \mathrm{CO}: 2\right) . .89$ Figure 43. Adsorption capacity of $\mathrm{CaO}$ sorbent with respect to time in different modes.. 94

Figure 44. Adsorption capacity of $\mathrm{CaO} / \mathrm{Ca}_{12} \mathrm{Al}_{14} \mathrm{O}_{33}(75 / 25$ wt \%) sorbent with respect to time in different modes 94

Figure 45. Adsorption capacity of sorbent $\mathrm{CaO} / \mathrm{Ca}_{12} \mathrm{Al}_{14} \mathrm{O}_{33}(50 / 50$ wt \%) with respect to time in different modes. 95

Figure 46. Adsorption capacity of sorbent $\mathrm{CaO} / \mathrm{Ca}_{12} \mathrm{Al}_{14} \mathrm{O}_{33}$ with respect to time in various ratios. 95

Figure 47. MFC Calibration curve for argon 104

Figure 48. MFC calibration curve for $\mathrm{CO} / \mathrm{He}$ mixture 104

Figure 49. MFC calibration curve for hydrogen 105

Figure 50. Calibration curve for HPLC pump. 105

Figure 51. A schematic chromatogram showing separation of different gases during the WGS reaction at $500^{\circ} \mathrm{C}$ 107 
Figure 52. A schematic chromatogram showing separation of different gases during the SEWGS reaction at $500^{\circ} \mathrm{C}$ 108

Figure 53. Calibration curve for helium using $\mathrm{CH}_{4}$ mixture diluted with steam........ 112 Figure 54. Calibration curve for helium using $\mathrm{CO} / \mathrm{He}$ mixture diluted with hydrogen, and argon.

Figure 55. Calibration curve for $\mathrm{He}$ using $\mathrm{CH}_{4}$ mixture diluted with hydrogen and argon.

Figure 56. Calibration curve for $\mathrm{H}_{2}$ using $\mathrm{CH}_{4}$ mixture diluted with argon and hydrogen.

Figure 57. Calibration curve for hydrogen using $\mathrm{CH}_{4}$ mixture and argon. 114

Figure 58. Calibration curve for $\mathrm{CO}_{2}$ using $\mathrm{CH}_{4}$ mixture diluted with hydrogen and argon.

Figure 59. Calibration curve for $\mathrm{CO}_{2}$ using $\mathrm{CH}_{4}$ mixture diluted with steam. 115 Figure 60. Calibration curve for $\mathrm{CO}$ using $\mathrm{CO} / \mathrm{He}$ mixture diluted with hydrogen and argon. 115

Figure 61. Calibration curve for $\mathrm{H}_{2} \mathrm{O}$ using $\mathrm{CH}_{4}$ mixture diluted with hydrogen and argon. 116

Figure 62. Moles of $\mathrm{CO}_{2}$ adsorbed with respect to time 129 Figure 63. Moles of $\mathrm{CO}_{2}$ adsorbed with respect time 130 


\section{CHAPTER 1 INTRODUCTION}

\subsection{Background}

Over the years, the hydrogen economy has received a great deal of attention. This arises from the fact that some kinds of fossil fuels such as petroleum and natural gas are likely to be exhausted in the near future. ${ }^{1}$ Nowadays, there is an increasing interest in hydrogen as an energy carrier since hydrogen is important in the attainment of a low-emission, environmental-benign, cleaner and more sustainable energy system. ${ }^{2}$ As a transportation fuel, hydrogen has some special properties, such as a rapid burning speed, high octane number, and no toxicity or ozone-forming potential. Hydrogen has a high energy yield $(122 \mathrm{KJ} / \mathrm{g})$, which is 2.75 times more than an average hydrocarbon fuel. ${ }^{2}$ In addition, unlike wind or solar energy, hydrogen can be stored and transported. It is therefore, considered as a viable energy carrier. Recently, there is a development in fuel cells, which can be used for transportation and primary power generation; hydrogen is a main fuel in the fuel cells. ${ }^{1}$ However the need for hydrogen is not limited to use as a source of energy. ${ }^{2}$ Hydrogen is also used as a feedstock in ammonia synthesis, alternative fuel synthesis by Fischer-Tropsch synthesis, methanol production, hydrogenation of hazardous wastes and fats, desulphurization, and reformulation of gasoline in refineries. $^{2}$

However, despite of all these advantages, hydrogen is not a freely available primary energy source in nature. ${ }^{2}$ It is a secondary form of energy that has to be manufactured. Hydrogen is present in a combined form with other elements. ${ }^{2}$ Water, natural gas, crude oils, hydrocarbons, coal, and biomass are the major sources of 
hydrogen. Hydrogen is produced on a large scale mainly by steam reforming, partial oxidation, and gasification of coal or biomass. ${ }^{2}$ Other possible methods of hydrogen production include electrolysis, thermochemical water decomposition, photobiological processes, and photo-electrochemical technology. ${ }^{2,6}$ Among all the current commercial hydrogen production methods, steam reforming is the most costeffective method, followed by partial oxidation of residual oil and gasification of coal or biomass. ${ }^{2}$ After the generation of synthesis gas (syngas, $\mathrm{CO}+\mathrm{H}_{2}$ ) from steam reforming and gasification of coal or biomass, the hydrogen contained in the syngas is further increased through the water-gas-shift reaction:

$$
\begin{aligned}
& \mathrm{CO}+\mathrm{H}_{2} \mathrm{O} \Leftrightarrow \mathrm{CO}_{2}+\mathrm{H}_{2} \\
& \Delta \mathrm{H}^{\circ}=-41.2 \mathrm{KJ} / \text { mole }, \Delta \mathrm{G}=-28.6 \mathrm{~kJ} / \text { mole }
\end{aligned}
$$

In this reaction, the oxygen in steam can be used to convert $\mathrm{CO}$ into $\mathrm{CO}_{2}$, thus transforming steam into hydrogen.

Hydrogen global production share by source and comparison of different hydrogen production methods are given in Table 1 and Table 2 respectively.

Table 1. Annual global hydrogen production share by source. ${ }^{2}$

\begin{tabular}{|c|c|c|}
\hline Source & (Billion cubic meters/year) & Share (\%) \\
\hline Natural gas & 240 & 48 \\
\hline Oil & 150 & 30 \\
\hline Coal & 90 & 18 \\
\hline Electrolysis & 20 & 4 \\
\hline Total & 500 & 100 \\
\hline
\end{tabular}


Table 2. Comparison of various hydrogen production methods. 1, 2, 4,5

\begin{tabular}{|l|l|l|}
\hline Process Type & \multicolumn{1}{|c|}{ Advantages } & \multicolumn{1}{c|}{ Disadvantages } \\
\hline $\begin{array}{l}\text { Steam } \\
\text { Reforming }\end{array}$ & $\begin{array}{l}\text { Most mature technology } \\
\text { Most cost-efficient processes } \\
\text { High hydrogen concentrations }\end{array}$ & $\begin{array}{l}\text { Finite resource (natural gas) } \\
\text { Rising natural gas prices } \\
\text { Not } \mathrm{CO}_{2} \text { neutral } \\
\text { Slow start up }\end{array}$ \\
\hline $\begin{array}{l}\text { Coal } \\
\text { gasification }\end{array}$ & $\begin{array}{l}\text { Inexpensive coal } \\
\text { Abundance of coal around the world. }\end{array}$ & $\begin{array}{l}\text { Produces more } \mathrm{CO}_{2} \text { than other technologies } \\
\text { Purification and separation of hydrogen at high } \\
\text { temperatures is challenging } \\
\text { Centralized production } \\
\text { Complex and expensive process }\end{array}$ \\
\hline $\begin{array}{l}\text { Biomass } \\
\text { gasification }\end{array}$ & $\begin{array}{l}\mathrm{CO}_{2} \text {-neutral } \\
\text { Decreased dependence on } \\
\text { conventional energy sources }\end{array}$ & $\begin{array}{l}\text { Very inefficient } \\
\text { Large amounts of land required }\end{array}$ \\
\hline Electrolysis & $\begin{array}{l}\text { No } \mathrm{CO}_{2} \text { production } \\
\text { However the emission of pollutants } \\
\text { depends on the source of power } \\
\text { Pure } \mathrm{H}_{2} \text { production }\end{array}$ & $\begin{array}{l}\text { Expensive } \\
\text { Huge amount of electricity required }\end{array}$ \\
\hline
\end{tabular}




\subsection{Statement of the problem}

The water-gas shift (WGS) reaction plays a vital role in increasing the production of hydrogen from fossil fuels. However, because of the reversibility and the moderate exothermicity of the reaction, WGS is thermodynamically unfavorable at elevated temperatures at which kinetics are favorable. In order to overcome this thermodynamic limitation while maintaining high reaction rates, a sorption-enhanced reaction concept can be developed, in which the catalyst and high-temperature sorbent are mixed together. In this process, the use of the sorbent along with the catalyst captures the $\mathrm{CO}_{2}$ produced from the WGS reaction. The loss of the product of the reversible reaction increases the forward reaction rate. However, the selection of sorbent plays a vital role.

The main purpose of this work is to develop a catalyst-sorbent mixture and a more-efficient process for in-situ removal of $\mathrm{CO}_{2}$ during the WGS. The main objectives of this project are listed below:

1. To evaluate the activity of the catalyst alone for WGS in the temperatures range of $350-600^{\circ} \mathrm{C}$.

2. To study the performance of inexpensive sorbents $\mathrm{CaO}$ and $\mathrm{CaO} / \mathrm{Ca}_{12} \mathrm{Al}_{14} \mathrm{O}_{33}$ $(75 / 25,50 / 50$ wt $\%)$ towards WGS reaction in the temperatures range of 350 $600^{\circ} \mathrm{C}$.

3. To study the sorption-enhanced water-gas shift reaction (SEWGS) using a mixture of WGS catalyst and sorbent at a temperature of $500{ }^{\circ} \mathrm{C}$. 


\section{CHAPTER 2 LITERATURE REVIEW}

\subsection{Introduction}

The water-gas shift reaction (WGS) is a well-developed industrial process in which water (in the form of steam) is mixed with carbon monoxide to obtain hydrogen and carbon dioxide expressed by equation (1). The WGS reaction is reversible and exothermic $\left(\Delta \mathrm{H}^{\circ}=-41.2 \mathrm{KJ} / \mathrm{mole}\right){ }^{9}$ As the reaction is exothermic in nature, WGS is thermodynamically unfavorable at elevated temperatures and the equilibrium constant $\mathrm{K}_{\mathrm{e}}$ of the reaction decreases with temperature, as shown in Figure $1.8,9$ In order to overcome this thermodynamic equilibrium limitation while maintaining high reaction rates, WGS is normally operated in multiple adiabatic stages with inter-cooling to obtain high overall conversion..$^{8,9}$ The high-temperature shift (HTS) reaction is carried out in the first stage, where the operation temperature ranges from $350-600{ }^{\circ} \mathrm{C}$. The low-temperature shift (LTS) reaction is carried out in the later stages, within the temperature ranges of $150-300{ }^{\circ} \mathrm{C} .{ }^{8}$ Different catalysts are used for WGS in these two stages. For example, iron-based $\left(\mathrm{Fe}_{3} \mathrm{O}_{4} / \mathrm{Cr}_{2} \mathrm{O}_{3}\right)$ catalyst can be used for HTS, while copper-based $\left(\mathrm{Cu} / \mathrm{ZnO} / \mathrm{Al}_{2} \mathrm{O}_{3}\right)$ and preciousmetal-based catalysts can be used industrially for LTS. ${ }^{8,9}$

The dual-stage method is expensive as this method requires high steam, multiple reactors, heat exchangers, and a number of separate product purification units, all of which are capital intensive. ${ }^{7}$ For example, to lower the $\mathrm{CO}$ content of the typical fuel gas from $45 \%$ to $3 \%$, a total of $1.18 \mathrm{~kg}$ steam is required per $1 \mathrm{~m}^{3}$ of $\mathrm{CO}$ at a total pressure of 60 bar and $410^{\circ} \mathrm{C}$. $^{10}$ To overcome these limitations, a 
sorption-enhanced reaction concept is developed, in which catalyst and sorbent are mixed together. The

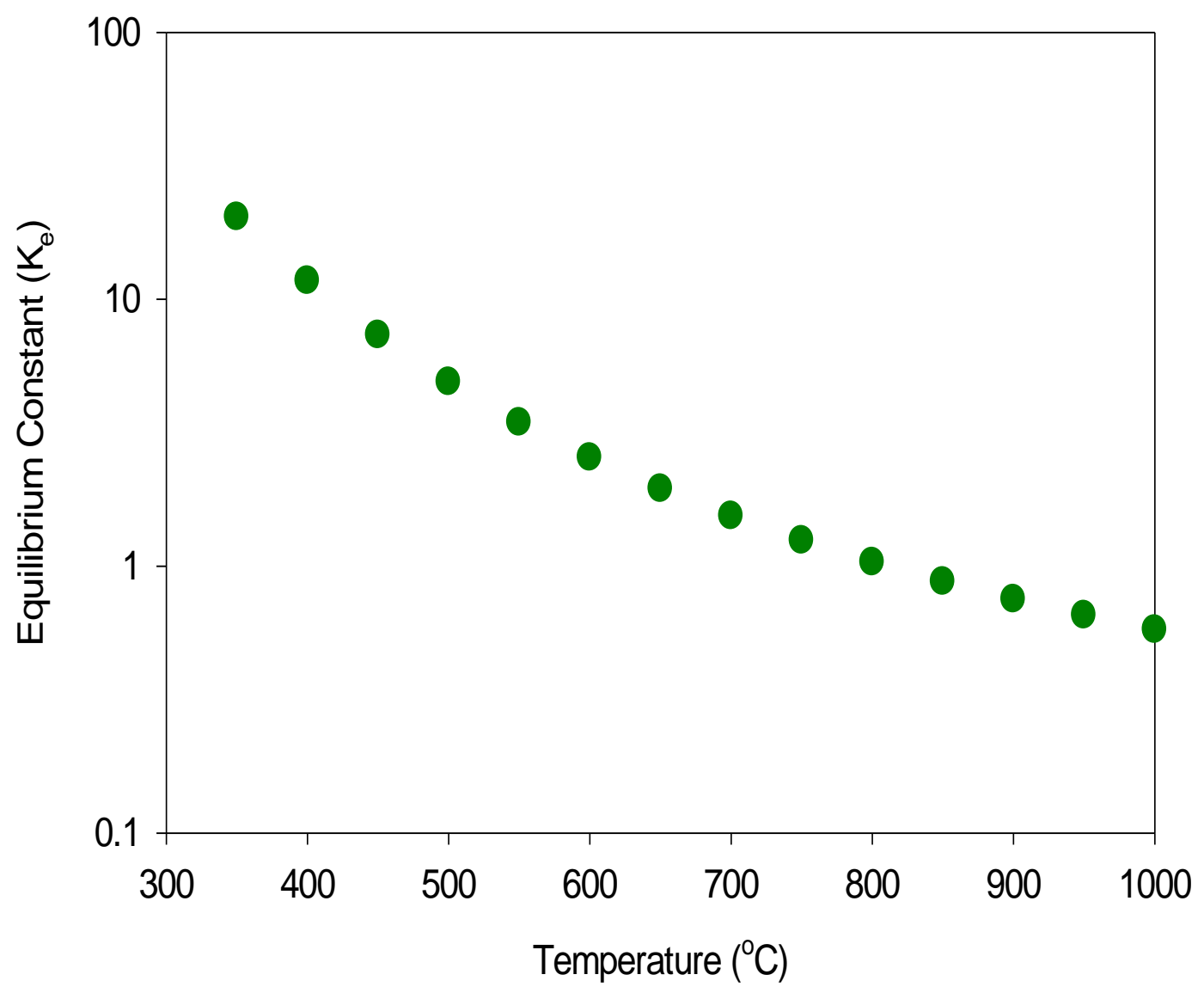

Figure 1. Equilibrium constant vs temperature for WGS reaction

mixture enhances the net rate of the reaction, simultaneously adsorbing the $\mathrm{CO}_{2}$ produced from WGS. The continuous removal of $\mathrm{CO}_{2}$ product from the reactor constantly drives the equilibrium-limited reaction forward. This will ensure a high yield and purity of hydrogen, with near-stoichiometric amounts of steam needed for the reaction. Besides, the reaction now can be carried out at higher temperatures, at which kinetics are favorable in the forward direction. In general, the sorbents 
currently tested for the removal of carbon dioxide are based on calcium oxide, hydrotalcites, potassium carbonate, lithium-oxide components, and alumina.

\subsection{Mechanism of WGS reaction}

The literature reports that the water-gas shift reaction probably occurs via one of the following mechanisms: ${ }^{8}$

1. The redox mechanism.

2. The formate mechanism.

3. The associative mechanism.

4. The carbonate mechanism.

In the redox mechanism, the reactive catalyst surface undergoes successive oxidation and reduction cycles by water and carbon monoxide respectively. In oxidation, the reactive catalyst surface is oxidized by adsorbed oxygen from $\mathrm{H}_{2} \mathrm{O}$, and the reduction of reactive catalyst surface occurs by adsorbed $\mathrm{CO}$, as $\mathrm{CO}$ is oxidized to $\mathrm{CO}_{2}$. In the formate mechanism, the reactants are adsorbed on the catalyst surface. Then the adsorbed water dissociates into an adsorbed hydroxyl group and atomic hydrogen. The hydroxyl group reacts with adsorbed carbon monoxide to form adsorbed formate, which finally decomposes into hydrogen and carbon dioxide. In the associative mechanism, adsorbed water dissociates into adsorbed $\mathrm{OH}$ and atomic hydrogen. Then the adsorbed hydroxyl will produce $\mathrm{CO}_{2}$ and atomic hydrogen by oxidizing the adsorbed CO. Finally, in the carbonate mechanism, the water adsorbed on the catalyst surface is decomposed into a hydroxyl group and atomic hydrogen. The hydroxyl groups decompose into surface oxygen atom and hydrogen. The adsorbed carbon monoxide reacts with an oxygen 
atom and form a carbonate intermediate. In the last step, the carbonate intermediate decomposes into carbon dioxide. The reactions of the various mechanisms are listed in Table 3.

Table 3. Various mechanisms for WGS reaction. ${ }^{8}$

\begin{tabular}{|l|l|l|}
\hline \multicolumn{1}{|c|}{ Associative mechanism } & Redox mechanism: & Formate mechanism \\
\hline $\mathrm{H}_{2} \mathrm{O}+\mathrm{S} \leftrightarrow \mathrm{H}_{2} \mathrm{O} \cdot \mathrm{S}$ & $\mathrm{H}_{2} \mathrm{O}+\mathrm{S} \leftrightarrow \mathrm{H}_{2} \mathrm{O} \cdot \mathrm{S}$ & $\mathrm{CO}+\mathrm{S} \leftrightarrow \mathrm{CO} \cdot \mathrm{S}$ \\
\hline $\mathrm{H} 2 \mathrm{O} \cdot \mathrm{S}+\mathrm{S} \leftrightarrow \mathrm{OH} \cdot \mathrm{S}+\mathrm{H} \cdot \mathrm{S}$ & $\mathrm{H}_{2} \mathrm{O} \cdot \mathrm{S} \leftrightarrow \mathrm{OH} \cdot \mathrm{S}+\mathrm{SH}$ & $\mathrm{H}_{2} \mathrm{O}+\mathrm{S} \leftrightarrow \mathrm{H}_{2} \mathrm{O} \cdot \mathrm{S}$ \\
\hline $\mathrm{CO}+\mathrm{S} \leftrightarrow \mathrm{CO}+\mathrm{S} \leftrightarrow \mathrm{CO} \cdot \mathrm{S}$ & $2 \mathrm{OH} \cdot \mathrm{S} \leftrightarrow \mathrm{H}_{2} \mathrm{O}+\mathrm{O} \cdot \mathrm{S}$ & $\mathrm{H}_{2} \mathrm{O} \cdot \mathrm{S}+\mathrm{S} \leftrightarrow \mathrm{OH} \cdot \mathrm{S}+\mathrm{H} \cdot$ \\
\hline $\begin{array}{l}\mathrm{CO} \cdot \mathrm{S}+\mathrm{OH} \cdot \mathrm{S} \leftrightarrow \\
\mathrm{CO}_{2} \cdot \mathrm{S}+\mathrm{H} \cdot \mathrm{S}\end{array}$ & $\mathrm{OH} \cdot \mathrm{S}+\mathrm{S} \leftrightarrow \mathrm{O} \cdot \mathrm{S}+\mathrm{H} \cdot \mathrm{S}$ & $\mathrm{CO} \cdot \mathrm{S}+\mathrm{OH} \cdot \mathrm{S} \leftrightarrow \mathrm{HOCC} \cdot \mathrm{S}+\mathrm{S}$ \\
\hline $\mathrm{CO}_{2} \cdot \mathrm{S} \leftrightarrow \mathrm{CO}_{2}+\mathrm{S}$ & $2 \mathrm{H} \cdot \mathrm{S} \leftrightarrow \mathrm{H}_{2}+2 \mathrm{~S}$ & $\mathrm{HCOO} \cdot \mathrm{S} \leftrightarrow \mathrm{CO}_{2}+\mathrm{H} \cdot \mathrm{S}$ \\
\hline $2 \mathrm{H} \cdot \mathrm{S} \leftrightarrow \mathrm{H}_{2}+2 \mathrm{~S}$ & $\mathrm{CO}+\mathrm{S} \leftrightarrow \mathrm{CO} \cdot \mathrm{S}$ & $2 \mathrm{H} \cdot \mathrm{S} \leftrightarrow \mathrm{H}_{2}+2 \mathrm{~S}$ \\
\hline & $\mathrm{CO} \cdot \mathrm{S}+\mathrm{O} \cdot \mathrm{S} \leftrightarrow \mathrm{CO}_{2} \cdot \mathrm{S}+$ & \\
\hline $\mathrm{Carbonate} \mathrm{mechanism}$ & $\mathrm{CO} \cdot \mathrm{S} \leftrightarrow \mathrm{CO}+\mathrm{S}$ & \\
\hline $\mathrm{CO}+2 \mathrm{O} \cdot \mathrm{S} \leftrightarrow \mathrm{CO} \cdot \mathrm{O}_{2}$ & & \\
\hline $\mathrm{CO}$ & & \\
\hline $\mathrm{CO} \cdot \mathrm{S} \leftrightarrow \mathrm{CO}_{3} \cdot \mathrm{S}+\mathrm{S} \leftrightarrow \mathrm{CO}_{2}+\mathrm{S}$ & & \\
\hline $\mathrm{H}_{2} \mathrm{O}+\mathrm{S} \leftrightarrow \mathrm{H}_{2} \mathrm{O} \cdot \mathrm{S}$ & & \\
\hline $\mathrm{H}_{2} \mathrm{O} \cdot \mathrm{S}+\mathrm{O} \cdot \mathrm{S} \leftrightarrow 2 \mathrm{OH} \cdot \mathrm{S}$ & & \\
\hline $2 \mathrm{OH} \cdot \mathrm{S} \leftrightarrow 2 \mathrm{O} \cdot \mathrm{S}+\mathrm{H}_{2}$ & & \\
\hline
\end{tabular}

Note: $\mathrm{S}$ represents an active site

\subsection{HTS and LTS catalysts for WGS reaction}

In the absence of the catalyst, the water-gas-shift reaction is very slow at accessible industrial temperatures; therefore different catalysts are used to increase 
the rate of water-gas-shift reaction. For example, iron- and copper-based catalysts, and precious-metal-based catalysts are industrially used for high-temperature shift (HTS) and low-temperature shift (LTS) reactions respectively. ${ }^{9}$

The HTS catalyst contains iron oxide, in the form of hematite $\left(\mathrm{Fe}_{2} \mathrm{O}_{3}\right)$, as well as chromium oxide $\left(\mathrm{Cr}_{2} \mathrm{O}_{3}\right)$, which acts as stabilizer, retards sintering, and inhibits the loss of specific surface area. ${ }^{11}$ The HTS catalyst has high catalytic activity and excellent thermal stability. Iron oxide in the form of magnetite $\left(\mathrm{Fe}_{3} \mathrm{O}_{4}\right)$ is believed to be the active phase in the reaction. Therefore, hematite is pre-reduced to magnetite before being used as a catalyst in the WGS reaction. ${ }^{12}$ Since the HTS reaction is exothermic, the reaction should be controlled to avoid the production of metallic iron, which may catalyze undesirable reactions such as hydrocarbon generation. ${ }^{13}$ In industrial processes, large amount of steam are used to inhibit the metallic iron formation. However, this increases operational cost. ${ }^{11}$

The effect of addition of transition metal oxides like $\mathrm{CuO}, \mathrm{CoO}$, and $\mathrm{ZnO}$ on the activity of the $\mathrm{Fe}_{2} \mathrm{O}_{3} / \mathrm{Cr}_{2} \mathrm{O}_{3}$ catalyst has also been studied. The addition of $\mathrm{CuO}$ and $\mathrm{CoO}$ in co-precipitated $\mathrm{Fe}_{2} \mathrm{O}_{3} / \mathrm{Cr}_{2} \mathrm{O}_{3}$ was found to enhance the reaction rate and shift the maximum of the conversion curve to a lower temperature, compared to unpromoted $\mathrm{Fe}_{2} \mathrm{O}_{3} / \mathrm{Cr}_{2} \mathrm{O}_{3}$ catalyst. ${ }^{14}$ Also, $\mathrm{Fe}_{2} \mathrm{O}_{3} / \mathrm{Cr}_{2} \mathrm{O}_{3} / \mathrm{CuO}$ can work in more severe conditions, like lower steam-to-carbon monoxide ratios, without being reduced to metallic iron which will favor undesirable side reactions ${ }^{11}$.

A series of $\mathrm{Fe}_{2} \mathrm{O}_{3} / \mathrm{Cr}_{2} \mathrm{O}_{3}$ catalysts promoted with 2 wt $\% \mathrm{~B}, \mathrm{~Pb}, \mathrm{Cu}, \mathrm{Ba}, \mathrm{Ag}$, or $\mathrm{Hg}$ were tested for WGS at 400 psig and various temperatures. ${ }^{15}$ Most of these dopants were found to increase the activity, except B which slightly poisons the 
activity. Addition of $\mathrm{Ba}^{2+}, \mathrm{Ag}^{2+}$, and $\mathrm{Hg}^{+}$increases the catalyst activity above the promotion levels observed with $\mathrm{Cu}^{2+}$ across the temperature range studied [350-440 $\left.{ }^{\circ} \mathrm{C}\right]^{15}$.

In view of environmental problems with chromium, one study ${ }^{12}$ replaced the chromium of $\mathrm{Fe}_{2} \mathrm{O}_{3} / \mathrm{Cr}_{2} \mathrm{O}_{3}$ with alumina and a low amount of copper. The surface area of the catalyst increases after chromium is replaced with alumina. The $\mathrm{Fe}_{2} \mathrm{O}_{3}$ catalyst promoted with $\mathrm{Al}_{2} \mathrm{O}_{3}$ and $\mathrm{CuO}$ produces the active phase more easily. The promoters also resist the over-reduction of magnetite $\left(\mathrm{Fe}_{3} \mathrm{O}_{4}\right)$ to iron oxide $(\mathrm{FeO})$ or iron species $(\mathrm{Fe})^{12}$. The promoted catalyst was also found to perform well at low steam-to-process-gas $(\mathrm{S} / \mathrm{G})$ ratios $(0.4)$ as well as at low temperatures. The activity shown by the iron catalyst promoted with $\mathrm{Al}_{2} \mathrm{O}_{3}$ and $\mathrm{CuO}$ was found to be closer to that of copper-doped iron-based commercial catalyst ${ }^{12}$. Moreover, the $\mathrm{Fe}_{2} \mathrm{O}_{3} / \mathrm{Al}_{2} \mathrm{O}_{3} / \mathrm{CuO}$ catalyst system can be discarded without any damage to the environment. However, studies of the stability of the aluminum-and copper-doped $\mathrm{Fe}_{2} \mathrm{O}_{3}$ catalyst system are needed for its commercial application. The chromium of iron-based commercial catalysts was also replaced with $\mathrm{Al}_{2} \mathrm{O}_{3} / \mathrm{CeO}_{2}$ and activities tested ${ }^{1}$. This catalyst has activity and thermal stability which are comparable to those of the commercial Fe-Cr catalyst. ${ }^{16}$

The $\mathrm{Pb}$-doped iron catalyst shows similar catalytic performance to that of a commercial Fe-Cr based catalyst. However, the stability of the Fe/Pb-based catalyst is very low compared to that of $\mathrm{Fe} / \mathrm{Cr}$-based WGS catalyst, since the activity of the Fe-Pb catalyst is sensitive to the trace amounts of sulfur in the feedstock. ${ }^{17}$ Oxides like $\mathrm{ZnO}, \mathrm{MgO}, \mathrm{SnO}_{2}, \mathrm{Al}_{2} \mathrm{O}_{3}, \mathrm{TiO}_{2}$, and $\mathrm{SiO}_{2}$ have $\mathrm{CO}$ conversion rates 2 to 7 orders 
of magnitude smaller than conversions over commercial iron-based catalyst. ${ }^{19}$ The WGS activity of $\mathrm{Mg}$ and $\mathrm{Zn}$ ferrites is also much lower than that of $\mathrm{Fe}-\mathrm{Cr}$ based catalyst. $^{18}$

Notably, not only the promoters, but also the activation process plays a crucial role in the activity and stability of the iron-based catalysts. The reduction of the iron-based catalysts in $\mathrm{CO} / \mathrm{CO}_{2}$ prior to the reaction increases the WGS catalytic activity. In contrast, the catalyst treatment in $\mathrm{H}_{2} / \mathrm{H}_{2} \mathrm{O}$ causes the growth of magnetite particles, leading to a decrease in catalytic activity. ${ }^{20}$

Cu-based catalysts are generally used for low-temperature WGS reaction. Because of the relatively low melting point of the copper, the commercial LTS catalyst is more sensitive to deactivation caused by sintering than the HTS catalyst. This causes the maximum operating temperature to be around $250^{\circ} \mathrm{C}^{8}$. The addition of $\mathrm{ZnO} / \mathrm{Al}_{2} \mathrm{O}_{3}$ not only stabilizes the copper crystallites against thermally induced sintering, but also increases the strength of the catalyst. ${ }^{9}$ Also $\mathrm{ZnO} / \mathrm{Al}_{2} \mathrm{O}_{3}$ minimizes the shrinkage during the reduction process. ${ }^{9}$ Copper-based-catalysts are easily deactivated by sulfur and chloride impurities. Hence gas streams must be cleaned before these catalysts can be used.$^{21}$

Precious metals supported on ceria and zirconium oxide have also been used as catalysts for WGS reaction. Even though precious metals have shown better catalytic activity, when compared with iron-based and copper-based catalysts, precious metals are expensive and hence economically unfeasible. Also, the precious metal catalysts produce methane along with hydrogen. ${ }^{22}$ Methane causes a decrease in production of hydrogen and releases excess heat. ${ }^{22}$ In spite of being 
Table 4. Comparison of various WGS catalysts. ${ }^{23}$

\begin{tabular}{|l|l|l|l|}
\hline \multicolumn{1}{|c|}{ Catalyst } & \multicolumn{1}{|c|}{ HTS catalysts } & \multicolumn{1}{|c|}{ LTS catalysts } & Precious-Metal catalysts \\
\hline Form & $3-10 \mathrm{~mm}$ pellets & $3-6 \mathrm{~mm}$ pellets & Monolith supported \\
\hline Poisons & Low sensitivity to sulfur & $\begin{array}{l}\text { Deactivates on exposure to sulfur and } \\
\text { halogens }\end{array}$ & $\begin{array}{l}\text { Tolerance to some } \\
\text { poisons }\end{array}$ \\
\hline $\begin{array}{l}\text { Thermal } \\
\text { stability }\end{array}$ & $\begin{array}{l}\text { Thermal stability up } \\
\text { to } 500^{\circ} \mathrm{C}\end{array}$ & Loss of activity above $280^{\circ} \mathrm{C}$ & Thermal stability $>400^{\circ} \mathrm{C}$ \\
\hline Activity & Not active below $350^{\circ} \mathrm{C}$ & High activity below $200^{\circ} \mathrm{C}$ & High activity above $250^{\circ} \mathrm{C}$ \\
\hline Other & $\begin{array}{l}\text { Self-heating material in } \\
\text { the reduced state } \\
\text { Inexpensive material } \\
\text { Insensitive to sulfur up to } \\
\text { certain level }\end{array}$ & $\begin{array}{l}\text { Needs to be carefully reduced } \\
\text { Self-heating material in the active } \\
\text { state (reduced) } \\
\text { Deactivates by water condensation } \\
\text { and air exposure } \\
\text { Need careful discharge from the } \\
\text { reactor (self heating catalyst) }\end{array}$ & $\begin{array}{l}\text { Insensitive to start-stop } \\
\text { and air exposure } \\
\text { No need for pre-reduction }\end{array}$ \\
\hline
\end{tabular}


expensive, the benefits of precious metal catalysts over iron- and copper-based catalysts can be accepted, if the durability (time for which the catalyst keeps sufficient level of activity) and redox resistance ( resistance to oxidation and

reduction) can be proven. ${ }^{22} \mathrm{~A}$ comparison of different WGS catalysts is given in Table 4.

\subsection{Catalyst pretreatment}

Pretreatment is a basic step in the activation of a WGS catalyst. Generally, pretreatment conditions (such as reduction temperature, reduction atmosphere, calcination temperature, and calcination atmosphere) strongly affect the active phase of the catalyst, which in turn, influences its performance. After the preparation step, WGS catalysts are pretreated by being calcined in the temperature range of 350- $450{ }^{\circ} \mathrm{C}$, either in air or $\mathrm{N}_{2}$ for $2-4$ hours to convert the basic carbonates to oxides.

The calcination step for the chromium-containing HTS catalyst is very important, since the temperature of the catalyst must be carefully controlled to avoid the formation of chromic oxide $\left(\mathrm{CrO}_{3}\right)$ from the air oxidation of chromia expressed by 9

$$
2 \mathrm{Cr}_{2} \mathrm{O}_{3}+3 \mathrm{O}_{2} \Rightarrow 4 \mathrm{CrO}_{3}
$$

The presence of the $\mathrm{Cr}(\mathrm{VI})$ compound in the HTS catalyst is undesirable, not only because of the potential health hazards associated with that compound, but also because of the possible operating problems as the catalyst is reduced ${ }^{9}$ For instance, leaching of chromium occurs when condensation of soluble hexavalent 
chromium takes place on unreduced catalyst in the reactor. In addition, the exothermic conversion of hexavalent chromium to trivalent chromium during the reduction leads to considerable evolution of heat and a correspondingly large increase in bed temperatures. ${ }^{9}$

The catalytically active phase of the HTS catalyst is magnetite $\left(\mathrm{Fe}_{3} \mathrm{O}_{4}\right)$. Therefore, commercial catalysts (which are normally supplied in the oxide form, $\mathrm{Fe}_{2} \mathrm{O}_{3}-\mathrm{Cr}_{2} \mathrm{O}_{3}-\mathrm{CuO}$ or prepared catalysts (via precipitation after the calcination step) need to be activated before use. The activation process comprises the partial reduction of hematite $\left(\mathrm{Fe}_{2} \mathrm{O}_{3}\right)$ to magnetite $\left(\mathrm{Fe}_{3} \mathrm{O}_{4}\right)$, and any $\mathrm{CrO}_{3}$ present to $\mathrm{Cr}_{2} \mathrm{O}_{3}{ }^{9}$

The WGS catalysts (commercial or prepared via precipitation) are reduced with $\mathrm{H}_{2} / \mathrm{N}_{2}$ or process gas mixtures of $\mathrm{H}_{2}, \mathrm{CO}, \mathrm{CO}_{2}$, and steam, within the temperature range of $300-500{ }^{\circ} \mathrm{C}$, using a flow rate of $50-200 \mathrm{cc} / \mathrm{min}$ for $2-3$ hours according to: $9,12,20$

$$
\begin{aligned}
& 3 \mathrm{Fe}_{2} \mathrm{O}_{3}+\mathrm{H}_{2} \Rightarrow 2 \mathrm{Fe}_{3} \mathrm{O}_{4}+\mathrm{H}_{2} \mathrm{O} \Delta \mathrm{H}=-16.3 \mathrm{kJmol}^{-1} \\
& 3 \mathrm{Fe}_{2} \mathrm{O}_{3}+\mathrm{CO} \Rightarrow 2 \mathrm{Fe}_{3} \mathrm{O}_{4}+\mathrm{CO}_{2} \Delta \mathrm{H}=+24.8 \mathrm{kJmol}^{-1} \\
& 2 \mathrm{CrO}_{3}+3 \mathrm{H}_{2} \Rightarrow \mathrm{Cr}_{2} \mathrm{O}_{3}+3 \mathrm{H}_{2} \mathrm{O} \Delta \mathrm{H}=-684.7 \mathrm{kJmol}^{-1} \\
& 2 \mathrm{CrO}_{3}+3 \mathrm{CO} \Rightarrow \mathrm{Cr}_{2} \mathrm{O}_{3}+3 \mathrm{CO}_{2} \Delta \mathrm{H}=-808.2 \mathrm{kJmol}^{-1}
\end{aligned}
$$

Approximately, $150 \mathrm{mg}$ of the catalyst is used at this flow rates ${ }^{12,20}$.

It is very important to avoid over-reduction of the magnetite $\left(\mathrm{Fe}_{3} \mathrm{O}_{4}\right)$ active material to iron oxide $(\mathrm{FeO})$ or iron species $(\mathrm{Fe})$ during this reduction process, since these compounds will promote methanation and carbon dioxide disproportionation. ${ }^{9}$ Moreover, even a relatively small degree of over-reduction can cause weakening and physical damage to the catalyst pellets. Therefore, the reduction conditions are 
chosen so that they permit the required reactions to occur without further reduction of $\mathrm{Fe}_{3} \mathrm{O}_{4}$ to iron oxide $(\mathrm{FeO})$ or metallic iron $(\mathrm{Fe})$.

\subsection{Side reactions in WGS reaction}

In WGS, side reactions become important when a low $\mathrm{H}_{2} \mathrm{O} / \mathrm{CO}$ ratio is used. For instance, in a gas system containing $\mathrm{CO}, \mathrm{CO}_{2}, \mathrm{H}_{2} \mathrm{O}$, and $\mathrm{H}_{2}$, the following side reactions may occur. ${ }^{21}$

$$
\begin{aligned}
& 2 \mathrm{CO} \Leftrightarrow \mathrm{C}+\mathrm{CO}_{2} \\
& \mathrm{CO}_{2}+\mathrm{H}_{2} \Leftrightarrow \mathrm{C}+2 \mathrm{H}_{2} \mathrm{O} \\
& 2 \mathrm{CO}+2 \mathrm{H}_{2} \Leftrightarrow \mathrm{CO}_{2}+\mathrm{CH}_{4} \\
& \mathrm{CO}+3 \mathrm{H}_{2} \Leftrightarrow \mathrm{CH}_{4}+\mathrm{H}_{2} \mathrm{O}
\end{aligned}
$$$$
\mathrm{CO}_{2}+4 \mathrm{H}_{2} \Leftrightarrow \mathrm{CH}_{4}+2 \mathrm{H}_{2} \mathrm{O}
$$

$\mathrm{C}+2 \mathrm{H}_{2} \Leftrightarrow \mathrm{CH}_{4}$

$$
\mathrm{CO}+\mathrm{H}_{2} \Leftrightarrow \mathrm{C}+\mathrm{H}_{2} \mathrm{O}
$$

These reactions produce undesired products such as carbon or methane. The extent to which these reactions proceed depends mainly on the catalyst system used, reaction conditions like $\mathrm{H}_{2} \mathrm{O} / \mathrm{CO}$ ratio, and the kinetics of the reaction. If these reactions occur at a high rate during the WGS reaction, a number of problems can arise. For example, the formation of carbon will cause blockage of the catalyst bed, 
deactivation of the catalyst, an increase in the pressure drop across the catalyst bed, and plugging and fouling of the equipment, which finally leads to shut-down of the

process. ${ }^{21}$ The formation of methane consumes hydrogen and alters the product composition. $^{8}$

\subsection{Carbon dioxide separation techniques}

The most commonly used methods for $\mathrm{CO}_{2}$ capture are absorption, adsorption and membrane gas separation. The currently preferred method for carbon dioxide capture is absorption using a chemical or physical solvent. Monoethanolamine (MEA), diethanolamine (DEA), and triethanolamine (TEA) are used for $\mathrm{CO}_{2}$ capture in chemical absorption while glycol and methanol are used commercially for $\mathrm{CO}_{2}$ capture in physical absorption. ${ }^{24}$

In chemical absorption, $\mathrm{CO}_{2}$ in the gas phase dissolves into a solution of water and amine compounds and forms protonated amine $\left(\mathrm{AH}^{+}\right)$, bicarbonate $\left(\mathrm{HCO}_{3}{ }^{-}\right)$, and carbonate $\left(\mathrm{ACO}_{2}{ }^{-}\right)$. As these reactions take place, more $\mathrm{CO}_{2}$ from the gas phase is driven into the liquid solution due to the lower chemical potential of the liquid phase compounds. Once the solution is saturated with $\mathrm{CO}_{2}$, it is removed from contact with gas stream and heated to remove the absorbed carbon dioxide from the amine solution. ${ }^{24}$

Although many alkanolamines are used industrially for $\mathrm{CO}_{2}$ capture, MEA is the most extensively used solvent for $\mathrm{CO}_{2}$ absorption because it has the highest alkalinity and, hence, reacts more rapidly with $\mathrm{CO}_{2}$. In addition, MEA is inexpensive and has the highest $\mathrm{CO}_{2}$ separation, which leads to relatively low overall costs. ${ }^{25}$ However, despite these advantages, MEA has the problem that it requires a huge 
amount of energy for regeneration. ${ }^{25}$ Another major drawback of MEA solvent is that it has low cyclic absorption capacity. In addition, irreversible reactions of MEA with minor impurities result in solvent degradation and loss. ${ }^{24}$ For example, MEA solvent reacts with $\mathrm{NO}_{x}, \mathrm{SO}_{x}, \mathrm{CO}$, and $\mathrm{O}_{2}$ which accompany the $\mathrm{CO}_{2}$ in flue gas and forms heat-stable salts such as formates, acetates, oxalates, thiocyanates, and sulphates. ${ }^{25,26}$ The presence of these heat-stable salts in the absorption solution creates many adverse effects such as increase in corrosion, increase in foaming tendency of the solution and increase in solution viscosity. ${ }^{25,26}$

Physical absorption occurs through mass transfer of $\mathrm{CO}_{2}$ gas molecules into the solvent. The physical absorption process is governed by Henry's law, which states that the amount of absorbed gas is proportional to its partial pressure. Glycol, methanol, tributyl phosphate, propylene carbonate, and polyethylene glycol are commonly used solvents for physical absorption. ${ }^{61}$ All these solvents are noncorrosive and non-toxic and only require carbon steel construction for a simple cycle process. Physical absorption is favorable at high partial pressures of $\mathrm{CO}_{2}(180-1200$ psi) and low temperatures $\left(-20-30^{\circ} \mathrm{C}\right) \cdot{ }^{61}$ Therefore, physical absorption processes are notably suitable for the treatment of $\mathrm{CO}_{2}$-rich gas streams.

Since these solvents interact weakly with the dissolved $\mathrm{CO}_{2}$ during physical absorption, the solvents are regenerated by depressurization. However, depressurization of the solvent results in a significant energy penalty. Also, these physical absorption solvents have low capacities for cyclic $\mathrm{CO}_{2}$ absorption. ${ }^{10}$ Besides, the $\mathrm{CO}_{2}$ capture capacity decreases as the temperature increases. The flue gas from power plants is at sub-atmospheric pressure and usually hot (800- 
$120^{\circ} \mathrm{C}$ ). Further, the $\mathrm{CO}_{2}$ concentration in flue gas is only about $10-15 \% .^{10}$ Therefore, the physical absorption requires compression and cooling of the flue gas. This makes physical absorption process energy intensive. ${ }^{10}$

$\mathrm{CO}_{2}$ can also adsorb physically on a bed of adsorbents such as zeolites and activated carbon. Since adsorption of $\mathrm{CO}_{2}$ occurs through weak interactions such as Van der Waals forces, these adsorbents have the advantages of low regeneration temperature and quick regeneration time.$^{24}$ However, these adsorbents have a high affinity towards water in the feed gas rather than $\mathrm{CO}_{2}$ in the product, hence water is removed. The removal of water drives the WGS reaction backward and hence reduces the amount of hydrogen produced..$^{27}$ Another major problem associated with these physical adsorbents is that the adsorption capacity for $\mathrm{CO}_{2}$ decreases as the temperature increases ${ }^{28}$ As a consequence, the use of physical adsorbents for insitu removal of $\mathrm{CO}_{2}$ during WGS reaction becomes inefficient as the reaction (WGS) is operated in the range of $300-600{ }^{\circ} \mathrm{C}$. Physical adsorbents such as activated carbon and zeolites have adequate adsorption capacity for $\mathrm{CO}_{2}$ at high pressures (1-10 atm) and ambient temperatures $\left(25-100^{\circ} \mathrm{C}\right)$. Various techniques like pressureswing adsorption (PSA), vacuum-pressure-swing adsorption (VPSA) and thermalswing adsorption (TSA) are used for $\mathrm{CO}_{2}$ regeneration. ${ }^{10}$

Membrane gas separation uses the difference in interaction between the membrane material and various components of the product gas $\left(\mathrm{CO}_{2}, \mathrm{H}_{2}, \mathrm{H}_{2} \mathrm{O}\right.$, and CO). This selective affinity for one gas component causes it to permeate faster than the others, thus achieving its separation. ${ }^{10}$ The efficiency of a membrane depends on its permeability (the flow rate of the gas through the membrane) and selectivity 
(the ability of one component of the gas to permeate faster than others) ${ }^{29}$ Some examples of membrane materials are polymer membranes, palladium membranes, inorganic microporous membranes, and ceramic porous membranes. ${ }^{10}$

Although the system for membrane gas-separation process is quite simple, there are a number of challenges: high cost, low $\mathrm{CO}_{2}$ recovery rate, and high pressure requirement. ${ }^{24}$ In addition, removal of impurities becomes inevitable. Impurities like $\mathrm{H}_{2} \mathrm{~S}$, COS, and arsene react with membranes and have a deleterious effect on membrane performance. ${ }^{30}$ Membranes usually cannot achieve high degrees of separation, so multiple stages of membranes and/or recycle of one stream are necessary. ${ }^{29}$ This leads to increased complexity, energy consumption and costs. ${ }^{29}$ Hence these membrane separation processes are generally not suitable for production of high-purity products.

\subsection{Reaction-based systems for $\mathrm{CO}_{2}$ removal}

The use of a reaction-based $\mathrm{CO}_{2}$ separation with facile kinetics will lead to: ${ }^{31}$

1. Lower sorbent requirements,

2. Smaller size reactors,

3. Lower pressure drop across the reactor,

4. Higher equilibrium carbon dioxide-capture capacity, and

5. Generation of pure $\mathrm{CO}_{2}$.

\subsubsection{Metal-oxide-based sorbents}

In reaction-based sorption processes, metal oxides are the most important sorbents. As metal oxides are basic in nature and $\mathrm{CO}_{2}$ is acidic in nature, metal 
oxides have good $\mathrm{CO}_{2}$ capture capacity. ${ }^{44}$ The metal oxide (MO) sorbent reacts with $\mathrm{CO}_{2}$ at high temperatures to produce the metal carbonates $\left(\mathrm{MCO}_{3}\right){ }^{31}$ The carbonation reaction can be given as

$$
\mathrm{MO}(\mathrm{s})+\mathrm{CO}_{2}(\mathrm{~g}) \Leftrightarrow \mathrm{MCO}_{3}(\mathrm{~s}) \quad \text { (Carbonation) }
$$

The metal carbonate formed is calcined at high temperature to regenerate the metal oxide, and pure $\mathrm{CO}_{2}$ can in principle be generated via ${ }^{31}$ :

$$
\mathrm{MCO}_{3}(\mathrm{~s}) \Leftrightarrow \mathrm{MCO}(\mathrm{s})+\mathrm{CO}_{2}(\mathrm{~g}) \text { (Calcination) }
$$

This pure $\mathrm{CO}_{2}$ can be economically compressed, cooled, liquefied, and transported for its sequestration.

Many metal oxides exhibit the carbonation and calcination reactions of Equations (9) and (10). However, metal carbonates that decompose above $1000^{\circ} \mathrm{C}$ are not suitable for $\mathrm{CO}_{2}$ capture, because their high calcination temperatures will impose severe energy penalties. ${ }^{31}$ Therefore, metal oxides whose calcination temperatures are within the desired temperature range of $300-800{ }^{\circ} \mathrm{C}$ are used for $\mathrm{CO}_{2}$ capture. These include $\mathrm{CaCO}_{3}\left(\sim 750^{\circ} \mathrm{C}\right), \mathrm{MgCO}_{3}\left(\sim 385^{\circ} \mathrm{C}\right), \mathrm{ZnCO}_{3}\left(\sim 340^{\circ} \mathrm{C}\right)$, $\mathrm{CuCO}_{3}\left(\sim 290{ }^{\circ} \mathrm{C}\right)$, and $\mathrm{MnCO}_{3}\left(\sim 440{ }^{\circ} \mathrm{C}\right)$. However, carbonation of metal oxides other than $\mathrm{CaO}$ has not been widely studied in the literature. ${ }^{31}$

\subsubsection{CaO-based sorbents}

$\mathrm{CaO}$ sorbents are derived from precursors such as limestone $\left(\mathrm{CaCO}_{3}\right)$, calcium hydroxide $\left(\mathrm{Ca}(\mathrm{OH})_{2}\right)$, dolomite $\left(\mathrm{MgCa}\left(\mathrm{CO}_{3}\right)_{2}\right)$, and huntite $\left(\mathrm{Mg}_{3} \mathrm{Ca}\left(\mathrm{CO}_{3}\right)_{4}\right)$. These sorbents have a high $\mathrm{CO}_{2}$ capture capacity and react rapidly over a wide range of temperatures and pressures. ${ }^{31}$ Limestone is widely available and $\mathrm{CaO}$ from limestone has a higher theoretical $\mathrm{CO}_{2}$ capture capacity $\left(0.79 \mathrm{~g} \mathrm{CO}_{2} / \mathrm{g} \mathrm{CaO}\right)$ than 
that of calcined dolomite $\left(0.46 \mathrm{~g} \mathrm{CO}_{2} / \mathrm{g} \mathrm{CaO} \cdot \mathrm{MgO}\right)$ and huntite $\left(0.25 \mathrm{~g} \mathrm{CO}_{2} /\right.$ $\mathrm{gCaO} \cdot 3 \mathrm{MgO}){ }^{32,}{ }^{33}$ The decline of $\mathrm{CO}_{2}$ capture of natural $\mathrm{CaO}$ sorbents over multiple carbonation-calcination cycles can be attributed to changes in the structure of the $\mathrm{CaO}$ particles during calcination at high temperatures $\left(850-1000{ }^{\circ} \mathrm{C}\right) .{ }^{34}$ Exposure of $\mathrm{CaO}$ particles to higher temperatures leads to a loss in surface area and porosity due to sintering, which reduces its reactivity. As the limestone cannot maintain a high $\mathrm{CO}_{2}$ capture capacity beyond 20 cycles, large quantities of limestone make-up are required for $\mathrm{CO}_{2}$ capture. Huntite has been found to give the highest fractional conversion and high $\mathrm{CO}_{2}$ sorption capacity over multiple carbonation-calcination cycles, followed by dolomite and calcite. ${ }^{32,33}$ This property of huntite is due to the excess pore volume created by the initial decomposition of $\mathrm{MgCO}_{3}$ during calcination at high temperatures $\left(850-1000^{\circ} \mathrm{C}\right)$. The $\mathrm{MgO}$ produced from the decomposition of $\mathrm{MgCO}_{3}$ provides structural property stability, which in turn contributes to better performance over multiple carbonation-calcination cycles. Since huntite has a higher MgO-to-CaO molar ratio than dolomite or limestone, huntite shows better performance over multiple carbonation-calcination cycles. ${ }^{32,33}$ However the limited availability of huntite and its low theoretical $\mathrm{CO}_{2}$ capacity $(0.25 \mathrm{~g}$ $\mathrm{CO}_{2} / \mathrm{g} \mathrm{CaO} .3 \mathrm{MgO}$ ) probably eliminates its use in a commercial process. ${ }^{33}$

Synthesized $\mathrm{CaO}$ sorbents have shown significantly improved $\mathrm{CO}_{2}$ capture and reaction stability over multiple carbonation-calcination cycles when compared to limestone and dolomite. ${ }^{34}$ For example, $\mathrm{CaO}$ supported on mayenite $\left(\mathrm{Ca}_{12} \mathrm{Al}_{14} \mathrm{O}_{33}\right)$ attains $41 \mathrm{wt} \% \mathrm{CO}_{2}$ capture at the end of 50 carbonation-and-calcination cycles. ${ }^{35}$ The calcium oxide from precipitated calcium carbonate (PCC-CaO) captures $36 \mathrm{wt}$ 
$\% \mathrm{CO}_{2}$ after 100 carbonation-and-calcination cycles. ${ }^{31}$ The high reactivity of PCC$\mathrm{CaO}$ is due to the predominant mesoporous structure, which allows the reactant gases to access the entire surface of the particles through large pores. ${ }^{31}$ The $\mathrm{CaO} / \mathrm{Ca}_{12} \mathrm{Al}_{14} \mathrm{O}_{33}$ sorbent also has a high reactivity, but the mechanism is different from that $\mathrm{PCC}-\mathrm{CaO}$. The high reactivity of $\mathrm{CaO} / \mathrm{Ca}_{12} \mathrm{Al}_{14} \mathrm{O}_{33}$ may be due to the formation of binder $\left(\mathrm{Ca}_{12} \mathrm{Al}_{14} \mathrm{O}_{33}\right)$ uniformly among the ultra-fine $\mathrm{CaO}$ particles, and this $\mathrm{Ca}_{12} \mathrm{Al}_{14} \mathrm{O}_{33}$ may retard the sintering of the $\mathrm{CaO}$ particles. ${ }^{35}$

Generally, the drawbacks associated with prepared or natural CaO-based sorbents are spalling induced by cycling and the need for high temperatures to carry out the regeneration.

\subsubsection{Mechanism of carbonation of CaO-based sorbents}

Calcium oxide will react with carbon dioxide and forms calcium carbonate represented by the reaction:

$$
\mathrm{CaO}(\mathrm{s})+\mathrm{CO}_{2}(\mathrm{~g}) \Leftrightarrow \mathrm{CaCO}_{3}(\mathrm{~s})
$$

The carbonation of calcium oxides occurs through three regimes. In the first regime, carbonate is formed, and this could provide active sites for further growth of a calcium carbonate layer. The second regime involves a rapid chemical reaction between calcium oxide and carbon dioxide. Most of the initial carbonation occurs due to fast kinetics. In the final regime, the carbonation reaction occurs very slowly due to the formation of an impervious calcium carbonate layer that prevents the further exposure of unreacted calcium oxide with carbon dioxide. The kinetics of the third regime is controlled by the diffusion of the $\mathrm{CO}_{2}$ through the formed calcium carbonate layer. $^{22}$ 


\subsubsection{Lithium-oxide-based sorbents}

Lithium-containing oxides have also been tested for the removal of carbon dioxide. Among these, lithium orthosilicate and lithium zirconate are the most favorable sorbents. The $\mathrm{CO}_{2}$ sorption rate on pure lithium zirconate is very low ${ }^{36}$, because an impervious shell of $\mathrm{Li}_{2} \mathrm{CO}_{3}$ is formed on the outer surface of the unreactive $\mathrm{Li}_{2} \mathrm{ZrO}_{3}$. But doped lithium zirconates have high $\mathrm{CO}_{2}$ sorption capacities

and fast sorption kinetics compared to those of pure $\mathrm{Li}_{2} \mathrm{ZrO}_{3} \cdot{ }^{36}$ These improvements are due to the formation of a eutectic carbonate layer composed of lithium carbonate $\left(\mathrm{Li}_{2} \mathrm{CO}_{3}\right)$ and potassium carbonate $\left(\mathrm{K}_{2} \mathrm{CO}_{3}\right)$ on the outer surface of the lithium zirconate particles. Since the diffusion of $\mathrm{CO}_{2}$ through the molten carbonate layer occurs at a much faster rate than through the solid phase, the formation of the $\mathrm{K}_{2} \mathrm{CO}_{3} / \mathrm{Li}_{2} \mathrm{CO}_{3}$ eutectic layer helps in facilitating the transfer of gaseous $\mathrm{CO}_{2}$ during the $\mathrm{CO}_{2}$ sorption. ${ }^{36}$

Compounds such as lithium ferrite $\left(\mathrm{LiFeO}_{2}\right)$, lithium nickel oxide $\left(\mathrm{LiNiO}_{2}\right)$, lithium titanate $\left(\mathrm{Li}_{2} \mathrm{TiO}_{3}\right)$, lithium sulfate $\left(\mathrm{Li}_{2} \mathrm{SiO}_{4}\right)$, and lithium metasilicate $\left(\mathrm{Li}_{2} \mathrm{SiO}_{3}\right)$ have also been tested for $\mathrm{CO}_{2}$ capture. Among these, $\mathrm{Li}_{4} \mathrm{SiO}_{4}$ is found to have the highest capacity $\left(28 \%\right.$ higher than $\left.\mathrm{Li}_{2} \mathrm{ZrO}_{3}\right)$ and sorption rate with $\mathrm{CO}_{2}$. However, the increase in weight during the carbonation is only about $70 \%$ of the theoretical maximum capacity. ${ }^{37} \mathrm{Li}_{4} \mathrm{SiO}_{4}$ can absorb $\mathrm{CO}_{2}$ faster than lithium zirconate at lower temperatures and even in low $\mathrm{CO}_{2}$ concentrations. ${ }^{38}$ Usually, adsorption of $\mathrm{CO}_{2}$ on these sorbents is affected by the mechanism in which the $\mathrm{Li}_{2} \mathrm{O}$ moves from $\mathrm{Li}_{2} \mathrm{ZrO}_{3}$ or $\mathrm{Li}_{4} \mathrm{SiO}_{4}$ to the surface and reacts reversibly with carbon dioxide. Since $\mathrm{Li}_{2} \mathrm{SO}_{4}$ 
contains many sites for lithium-ion hopping, the $\mathrm{CO}_{2}$ absorption rate for $\mathrm{Li}_{2} \mathrm{SiO}_{4}$ is faster than that for $\mathrm{Li}_{2} \mathrm{ZrO}_{3}{ }^{38}$

The main advantages of lithium-oxide-based sorbents over CaO-based sorbents are that the former require less energy for sorbent regeneration (calcination) and are unusually stable over multiple cycles. ${ }^{39}$ But lithium is not abundant, and the cost is expensive when compared with other metal compounds. ${ }^{40}$ Also, the $\mathrm{CO}_{2}$ sorption capacity of lithium-based-sorbents is lower than that of $\mathrm{CaO}$ based sorbents. Since lithium-based sorbents have less favorable thermodynamic properties, the product $\mathrm{H}_{2}$ concentrations are lower than what can be obtained using calcium-based sorbents. ${ }^{41}$

\subsubsection{Metal-carbonate-based sorbent}

The sorption of $\mathrm{CO}_{2}$ on $\mathrm{K}_{2} \mathrm{CO}_{3}$ depends on the type of the support and the temperature of the activation process. Sorption of $\mathrm{CO}_{2}$ on $\mathrm{K}_{2} \mathrm{CO}_{3}$ impregnated on supports such as activated carbon, alumina, $\mathrm{MgO}$, and $\mathrm{TiO}_{2}$ has been reported in the literature ${ }^{42,43,8}$. Sorbents like $\mathrm{K}_{2} \mathrm{CO}_{3} /$ activated carbon, $\mathrm{K}_{2} \mathrm{CO}_{3} / \mathrm{TiO}_{2}, \mathrm{~K}_{2} \mathrm{CO}_{3} / \mathrm{MgO}$, and $\mathrm{K}_{2} \mathrm{CO}_{3} / \mathrm{Al}_{2} \mathrm{O}_{3}$, which show good $\mathrm{CO}_{2}$-capture capacity at low temperature $\left(60{ }^{\circ} \mathrm{C}\right)$, can be completely regenerated above $130{ }^{\circ} \mathrm{C}, 130{ }^{\circ} \mathrm{C}, 350{ }^{\circ} \mathrm{C}$, and $400{ }^{\circ} \mathrm{C}$, respectively. ${ }^{42}$ The $\mathrm{CO}_{2}$-capture capacity of $\mathrm{K}_{2} \mathrm{CO}_{3}$ supported on $\mathrm{Al}_{2} \mathrm{O}_{3}$ and $\mathrm{MgO}$, after regeneration at low temperatures (less than $200^{\circ} \mathrm{C}$ ), decreases due to the formation of intermediate compounds $\left(\mathrm{KAl}\left(\mathrm{CO}_{3}\right)_{2}(\mathrm{OH})_{2}, \quad \mathrm{~K}_{2} \mathrm{Mg} \quad\left(\mathrm{CO}_{3}\right)_{2}\right.$ and $\mathrm{K} 2 \mathrm{Mg}\left(\mathrm{CO}_{3}\right)_{2} \cdot 4 \mathrm{H}_{2} \mathrm{O}$ ), which are not completely converted to the original $\mathrm{K}_{2} \mathrm{CO}_{3}$ phase. ${ }^{42}$ But in the case of $\mathrm{K}_{2} \mathrm{CO}_{3} / \mathrm{TiO}_{2}$ and $\mathrm{K}_{2} \mathrm{CO}_{3}$ /activated carbon, a $\mathrm{KHCO}_{3}$ 
phase is formed during the adsorption. This phase can be easily converted into the original phase during the regeneration, even at low temperature $\left(150^{\circ} \mathrm{C}\right)$.

The total $\mathrm{CO}_{2}$-capture capacities of $\mathrm{K}_{2} \mathrm{CO}_{3} / \mathrm{TiO}_{2}$ and $\mathrm{K}_{2} \mathrm{CO}_{3} / \mathrm{ZrO}_{2}$ are maintained constant during multiple $\mathrm{CO}_{2}$ absorption /regeneration cycles, and their regeneration temperatures are the lowest relative to potassium carbonate supported on all other supports. ${ }^{42,43}$ Even though the potassium-based-carbonates have good adsorption/ desorption properties in the temperature range of $60-100{ }^{\circ} \mathrm{C}$, they are not suitable for in-situ removal of $\mathrm{CO}_{2}$ from the WGS and reforming reactions, because these reactions are operated within in the temperature range of 200-600 ${ }^{\circ} \mathrm{C} .^{8}$

\subsection{Hydrotalcite compounds}

Hydrotalcite compounds (HTCs) are also known as layered double hydroxides. They can be represented by the general formula $\left[\left(\mathrm{M}^{2+}{ }_{1-}\right.\right.$ $\left.\left.\left.\left.\mathrm{x} \cdot \mathrm{M}^{3+}{ }_{\mathrm{x}}(\mathrm{OH})_{2}\right)\right)^{\mathrm{x}+} \cdot\left(\mathrm{A}^{\mathrm{n}-}{ }_{\mathrm{x} / \mathrm{n}} \cdot \mathrm{mH}_{2} \mathrm{O}\right)^{\mathrm{x}-}\right)\right]$, where $\mathrm{M}^{2+}$ represents $\mathrm{Mg}^{2+}, \mathrm{Ni}^{2+}, \mathrm{Zn}^{2+}, \mathrm{Cu}^{2+}$ or $\mathrm{Mn}^{2+} ; \mathrm{M}^{3+}$ represents $\mathrm{Al}^{3+}, \mathrm{Fe}^{3+}$ or $\mathrm{Cr}^{3+}$; and $\mathrm{A}^{\mathrm{n-}}$ represents $\mathrm{CO}_{3}{ }^{2-}, \mathrm{SO}_{4}{ }^{2-}, \mathrm{NO}_{3}{ }^{-}, \mathrm{Cl}^{-}$or $\mathrm{OH}^{-} .^{44}$ The $\mathrm{CO}_{2}$ adsorption capacity of the HTCs is mainly affected by cation, anion, water/steam, temperature, and chemical modification. The low water content in the $\mathrm{HTC}$ and the presence of steam in feed gas are favorable for adsorption of $\mathrm{CO}_{2}$ onto HTC at high temperature. The aluminum content in the substituted HTC strongly affects the adsorption capacity of carbon dioxide. ${ }^{44}$ As the aluminum content increases in the HTC, the density of the layer charge in HTC increases, which is favorable for adsorption of carbon dioxide. Simultaneously, there is also a 
decrease in the interlayer spacing of $\mathrm{HTC}$, and this reduces the number of highstrength $\mathrm{CO}_{2}$-adsorption sites. Therefore, there is an optimum aluminum content for adsorption of carbon dioxide. HTCs containing $\mathrm{CO}_{3}{ }^{2-}$ show higher adsorption capacities than those of $\mathrm{OH}^{-}$containing HTC sorbents. This is due to the presence of more void spaces in the interlayer of the $\mathrm{CO}_{3}{ }^{2-}$-containing $\mathrm{HTC}$ sorbents. ${ }^{44}$ Addition of $\mathrm{K}_{2} \mathrm{CO}_{3}$ enhances the adsorption capacity of the $\mathrm{HTC}$ by a factor of 3 , when compared to non-impregnated HTC adsorbents. ${ }^{45}$ As the HTC can be regenerated with low energy input and at low temperature, the sorbent durability is increased, avoiding sintering. ${ }^{46}$ However, $\mathrm{HTCs}$ have lower $\mathrm{CO}_{2}$-capture capacity than $\mathrm{Ca}$ based sorbents, and are considerably more expensive. ${ }^{46}$ The adsorption temperature, physical properties, advantages, and disadvantages of different sorbents discussed in Sections 2.5- 2.7 are given in Tables $5 \& 6$. 
Table 5. Comparison of various sorbents. ${ }^{27,38,41,44,45,57}$

\begin{tabular}{|c|c|c|c|c|}
\hline Sorbent type & $\begin{array}{l}\text { Temperature }\left(^{\circ}\right. \\
\text { C) }\end{array}$ & $\begin{array}{l}\text { Surface } \\
\text { area } \\
\left(\mathrm{m}^{2} / \mathrm{g}\right)\end{array}$ & Advantages & Disadvantages \\
\hline $\begin{array}{c}\text { CaO-based-sorbents } \\
\text { Dolomite }\left(\mathrm{MgCa}\left(\mathrm{CO}_{3}\right)_{2}\right) \\
\text { Calcite }(\mathrm{CaCO}) \\
\text { Huntite }\left(\mathrm{MgCa}\left(\mathrm{CO}_{3}\right)_{4}\right) \\
\text { Lime } \mathrm{Ca}(\mathrm{OH})_{2} \\
\text { Carbonation: } \\
\mathrm{CaO}+\mathrm{CO}_{2} \leftrightarrow \mathrm{CaCO} \mathrm{CO}_{3} \\
\text { Regeneration: } \\
\mathrm{CaCO}_{3}+\text { Heat } \leftrightarrow \mathrm{CaO}+\mathrm{CO}_{2}\end{array}$ & $500-650$ & $1-50$ & $\begin{array}{l}\text { 1. Large sorption } \\
\text { capacity } \\
\text { 2. Low cost } \\
\text { 3. Wide availability } \\
\text { 4. Fast sorption } \\
\text { kinetics } \\
\text { 5. Good kinetics }\end{array}$ & $\begin{array}{l}\text { 1. High regeneration } \\
\text { temperature } \\
\text { 2. Sulfur removal is } \\
\text { often needed } \\
\text { 3. Poor stability } \\
\text { because of pore } \\
\text { blocking and } \\
\text { sintering }\end{array}$ \\
\hline $\begin{array}{c}\text { Hydrotalcite- based } \\
\text { compounds } \\
\mathrm{Mg}_{6} \mathrm{Al}_{2}\left(\mathrm{CO}_{3}\right)(\mathrm{OH})_{16} \cdot 4 \mathrm{H}_{2} \mathrm{O}\end{array}$ & $300-450$ & $30-270$ & $\begin{array}{l}\text { 1. Low regeneration } \\
\text { temperature } \\
\text { 2. Good stability }\end{array}$ & $\begin{array}{l}\text { 1. Expensive and poor } \\
\text { adsorption capacity }\end{array}$ \\
\hline $\begin{array}{c}\text { Lithium-zirconate-based } \\
\text { sorbents } \\
\begin{array}{c}\mathrm{Li}_{2} \mathrm{ZrO}_{3}+\mathrm{CO}_{2} \rightarrow \mathrm{Li}_{2} \mathrm{CO}_{3}+ \\
\mathrm{ZrO}_{2}\end{array}\end{array}$ & $400-500$ & & $\begin{array}{l}\text { 1. Low regeneration } \\
\text { temperature } \\
\text { 2. Fair adsorption } \\
\text { 3. Good stability } \\
\text { 4. Attrition resistance } \\
\text { in thermal cycling } \\
\text { tests }\end{array}$ & $\begin{array}{l}\text { 1. Expensive and less } \\
\text { abundance } \\
\text { 2. Less favorable } \\
\text { thermodynamic } \\
\text { properties } \\
\text { 3. Low sorption rate }\end{array}$ \\
\hline
\end{tabular}


Table 6. Comparison of various sorbents. ${ }^{27,38,41,44,45,57}$

\begin{tabular}{|c|c|c|c|c|}
\hline 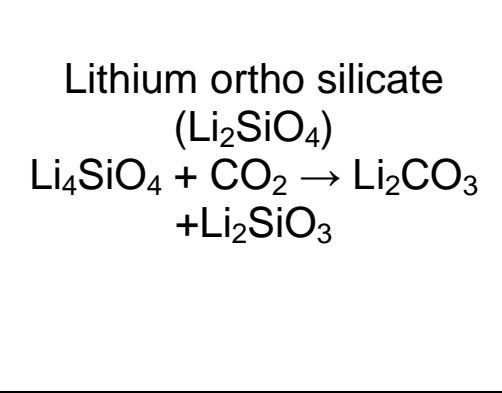 & $500-600$ & -- & $\begin{array}{l}\text { 1. Fair adsorption and stability } \\
\text { 2. Low regeneration } \\
\text { temperature } \\
\text { 3. Attrition resistance in } \\
\text { thermo cycles } \\
\text { 4. Effective in the presence of } \\
\mathrm{H}_{2} \mathrm{~S} \\
\text { 5. Fast kinetics }\end{array}$ & $\begin{array}{l}\text { 1. Less favorable } \\
\text { thermodynamics } \\
\text { properties } \\
\text { 2. Expensive and less } \\
\text { abundance }\end{array}$ \\
\hline Carbon-based sorbents & $25-75$ & $600-3370$ & $\begin{array}{l}\text { 1. Low cost } \\
\text { 2. Easily modified structure } \\
\text { 3. Low regeneration } \\
\text { temperature }\end{array}$ & $\begin{array}{l}\text { 1. Adsorption of } \mathrm{CO}_{2} \\
\text { decreases as the } \\
\text { temperature } \\
\text { increases } \\
\text { 2. Low adsorption } \\
\text { capacity } \\
\text { 3. They have high } \\
\text { affinity towards water } \\
\text { rather than } \mathrm{CO}_{2}\end{array}$ \\
\hline Zeolite-based compounds & $25-75$ & $600-3370$ & $\begin{array}{l}\text { 1. High surface area } \\
\text { 2. Low cost } \\
\text { 3. Low regeneration } \\
\text { temperature } \\
\text { 4. Quick regeneration } \\
\text { temperature }\end{array}$ & $\begin{array}{l}\text { 1. Adsorption of } \mathrm{CO}_{2} \\
\text { decreases as the } \\
\text { temperature } \\
\text { increases } \\
\text { 2. Low adsorption } \\
\text { capacity } \\
\text { 3. They have high } \\
\text { affinity towards water } \\
\text { rather than } \mathrm{CO}_{2}\end{array}$ \\
\hline
\end{tabular}




\subsection{Summary}

Among all the sorbents described in the literature and reviewed in Sections 2.5-2.7, $\mathrm{CaO}-$ based sorbents appear to be the best. Even though their regeneration temperature is very high (of the order of $800-950{ }^{\circ} \mathrm{C}$ ), CaO-based sorbents are widely available and inexpensive and have a high adsorption capacity. Correspondingly, $\mathrm{CaO}$-based sorbents are widely used for $\mathrm{CO}_{2}$ capture from reforming reactions and WGS reactions.

\subsection{Sorption-enhanced reaction process}

The process in which in-situ separation of one or more products is performed in the reaction chamber is called sorption-enhanced reaction (SER). Generally, this SER process is used in equilibrium-limited reactions such as steam reforming and WGS. In the sorption-enhanced WGS process, the WGS catalyst and sorbent are admixed. The mixture containing the catalyst and the sorbent adsorbs the $\mathrm{CO}_{2}$ and thereby enhances the rate of reaction. The advantages of SER process over the conventional methods of WGS are given below. ${ }^{49}$

1. According to Le Chatelier's principle, removal of $\mathrm{CO}_{2}$ from the reaction zone will drive the WGS reaction forward. This will allow (i) higher conversion of $\mathrm{CO}$ to $\mathrm{H}_{2}$ than that obtained by thermodynamically limited conventional WGS reaction, (ii) enhancement of the reaction rate in the forward direction, (iii) the use of a lower $\mathrm{H}_{2} \mathrm{O} / \mathrm{CO}$ ratio in the feed gas and (iv) a relatively higher 
operating temperature of the reactor (kinetics are favored at high temperature) without thermodynamic limitation.

2. This process also eliminates any subsequent separation process needed.

3. The simultaneous production of an essentially pure and compressed $\mathrm{CO}_{2}$ byproduct promotes subsequent $\mathrm{CO}_{2}$ sequestration, and the sale of the $\mathrm{CO}_{2}$ product.

4. Lower capital and energy costs due to simple equipment used in SER, in which there is no need to install a separate product purification unit.

\subsection{Impurities from syngas}

Synthesis gas can be obtained from the gasification of biomass and coal or from steam reforming of natural gas. In the gasification process, steam or oxygen is fed to a gasifier at high temperatures (greater than $700^{\circ} \mathrm{C}$ ) to convert coal, biomass or any carbonaceous material into $\mathrm{CO}, \mathrm{CO}_{2}$, and $\mathrm{H}_{2}$. In addition to these primary products, the gasification of coal or biomass also produces varying levels of impurities such as $\mathrm{NO}_{x}, \mathrm{SO}_{x}$, chloride, sulfides, cyanide compounds, particulate matter, organic tar, and some hydrocarbon compounds. ${ }^{50}$ The impurities produced differ by feedstock and gasification process. ${ }^{51}$ Coal gasification produces more $\mathrm{NO}_{\mathrm{x}}$ and $\mathrm{SO}_{\mathrm{X}}$ impurities, whereas biomass gasification produces more hydrocarbon impurities. ${ }^{52,53}$ The composition of synthesis gas produced from coal in different gasifiers is given in Table 7. The effect of impurities is given in Table 8. The main impurities in syngas produced from coal are sulfur, halides, and carbonyl sulfide compounds. These impurities affect the activity of the WGS catalysts. The 
deactivation of the catalyst will depend on the concentration of impurities in the feed. The $\mathrm{Cu} / \mathrm{Zn}$-based catalysts are extremely sensitive to $\mathrm{H}_{2} \mathrm{~S}$ and completely deactivate in $\mathrm{H}_{2} \mathrm{~S}$ even at low concentrations (50ppm). ${ }^{21,55}$

Table 7. Synthesis gas composition (volume \%) generated by different gasifiers. ${ }^{54}$

\begin{tabular}{|c|c|c|c|}
\hline $\begin{array}{c}\text { Gasifier type } \\
\text { (Coal) }\end{array}$ & $\begin{array}{c}\text { Moving bed } \\
\text { Lurgi (Illinois } \\
\text { no.6) }\end{array}$ & $\begin{array}{c}\text { Fluidized bed } \\
\text { Winkler } \\
\text { (Texas } \\
\text { lignite) }\end{array}$ & $\begin{array}{c}\text { Entrained bed } \\
\text { Kopper- } \\
\text { Totzek } \\
\text { (llinois no.6) }\end{array}$ \\
\hline $\mathrm{Ar}$ & Trace & 0.7 & 0.9 \\
\hline $\mathrm{CH}_{4}$ & 3.3 & 4.6 & - \\
\hline $\mathrm{C}_{2} \mathrm{H}_{6}$ & 0.2 & - & - \\
\hline $\mathrm{CO}$ & 5.8 & 33.1 & 43.8 \\
\hline $\mathrm{CO}$ & 11.8 & 15.5 & 4.6 \\
\hline $\mathrm{COS}_{2}$ & Trace & - & 0.1 \\
\hline $\mathrm{H}_{2}$ & 16.1 & 28.3 & 21.1 \\
\hline $\mathrm{H}_{2} \mathrm{O}$ & 61.8 & 16.8 & 27.5 \\
\hline $\mathrm{H}_{2} \mathrm{~S}$ & 0.5 & 0.2 & 1.1 \\
\hline & & & \\
\hline
\end{tabular}

The $\mathrm{H}_{2} \mathrm{~S}$ reacts with copper and zinc oxide to form $\mathrm{Cu}_{2} \mathrm{~S}$ and $\mathrm{ZnS}$ according to: ${ }^{9}$

$$
\begin{array}{ll}
2 \mathrm{Cu}+\mathrm{H}_{2} \Rightarrow \mathrm{Cu}_{2} \mathrm{~S}+\mathrm{H}_{2} & \Delta \mathrm{H}=-59.4 \mathrm{kjmol}^{-1} \\
\mathrm{ZnO}+\mathrm{H}_{2} \mathrm{~S} \Rightarrow \mathrm{ZnS}+\mathrm{H}_{2} \mathrm{O} & \Delta \mathrm{H}=-76.6 \mathrm{kjmol}^{-1}
\end{array}
$$

But compared to $\mathrm{Cu} / \mathrm{Zn}$ catalysts, the iron-chromium-based catalyst and precious metals supported on ceria or zirconia are less susceptible to sulfur, at least up to 50 ppm $\mathrm{H}_{2} \mathrm{~S}$. However above 50 ppm, a decline in catalytic activity is observed. ${ }^{55}$ The $\mathrm{H}_{2} \mathrm{~S}$ in the feed reacts with the active phase $\left(\mathrm{Fe}_{3} \mathrm{O}_{4}\right)$ of the $\mathrm{HT}$ shift catalyst and forms FeS by: ${ }^{9}$ 


$$
\mathrm{Fe}_{3} \mathrm{O}_{4}+3 \mathrm{H}_{2} \mathrm{~S}+\mathrm{H}_{2} \Rightarrow 3 \mathrm{FeS}+4 \mathrm{H}_{2} \mathrm{O} \quad \Delta \mathrm{H}=-75 \mathrm{kjmol}-1
$$

Any carbonyl sulfide present in the feed gas is converted to hydrogen sulfide $\left(\mathrm{H}_{2} \mathrm{~S}\right)$ according to:

$$
\mathrm{COS}+\mathrm{H}_{2} \mathrm{O} \Rightarrow \mathrm{CO}_{2}+\mathrm{H}_{2} \mathrm{~S} \quad \Delta \mathrm{H}=-34.6 \mathrm{kjmol}^{-1}
$$

The $\mathrm{H}_{2} \mathrm{~S}$ eventually deactivates the active phase $\left(\mathrm{Fe}_{3} \mathrm{O}_{4}\right)$ of iron-chromium based catalyst. The sulfided catalyst also shows catalytic activity, but its activity is only about half that of the original iron catalyst. Therefore, the volume of catalyst needed is doubled. ${ }^{9}$ The WGS activities of various catalysts in the presence of $\mathrm{H}_{2} \mathrm{~S}$ are given in Table 9.

\begin{tabular}{|c|c|c|}
\hline Class & Contaminant & Potential effect \\
\hline $\begin{array}{l}\text { Sulfur } \\
\text { compounds }\end{array}$ & $\begin{array}{l}\mathrm{H}_{2} \mathrm{~S}, \mathrm{COS} \\
\mathrm{CS}_{2}, \mathrm{C}_{4} \mathrm{H}_{4} \mathrm{~S}\end{array}$ & $\begin{array}{l}\text { Poisoning of the catalytic reaction sites } \\
\text { Corrosion }\end{array}$ \\
\hline Particulates & Coal fines, ash & $\begin{array}{l}\text { Plugging of gas passages } \\
\text { Deactivation of catalysts }\end{array}$ \\
\hline Hydrocarbons & $\mathrm{C}_{6} \mathrm{H}_{6}, \mathrm{C}_{10} \mathrm{H}_{8}, \mathrm{C}_{14} \mathrm{H}_{10}$ & $\begin{array}{l}\text { Carbon deposition, which causes loss of } \\
\text { surface area } \\
\text { Lower the heat transfer from catalyst to } \\
\text { gas }\end{array}$ \\
\hline Halides & $\mathrm{HCl}, \mathrm{HF}, \mathrm{HBr}$ & Corrosion \\
\hline Tar compounds & $\begin{array}{l}\text { Refractive } \\
\text { aromatics }\end{array}$ & Coke formation \\
\hline Alkali metals & $\begin{array}{l}\text { Sodium, potassium } \\
\text { compounds }\end{array}$ & $\begin{array}{l}\text { Hot corrosion } \\
\text { Catalyst poisoning }\end{array}$ \\
\hline
\end{tabular}

Table 8. Contaminants from syngas and their potential effects. ${ }^{49,50}$ 
Table 9. The WGS activities of various catalysts in the presence of $\mathrm{H}_{2} \mathrm{~S}^{56}$

\begin{tabular}{|c|c|c|c|c|c|}
\hline \multirow{2}{*}{$\begin{array}{c}\text { Catalyst } \\
\text { description }\end{array}$} & Temperature $\left({ }^{\circ} \mathbf{C}\right)$ & \multicolumn{4}{|c|}{ Co conversions at different $\mathrm{H}_{2} \mathbf{S}$} \\
& & \multicolumn{5}{|c|}{ concentrations (ppm) in the feed } \\
\cline { 3 - 6 } & & $\mathbf{0}$ & $\mathbf{5 0}$ & $\mathbf{2 0 0}$ & $\mathbf{1 0 0 0}$ \\
\hline $\mathrm{Cu} / \mathrm{Zn}$ & 240 & 80 & 0 & 0 & 0 \\
\hline $\mathrm{Fe}-\mathrm{Cr}$ & 300 & 3 & 2.4 & 2.4 & 1.8 \\
\hline $\mathrm{Fe}-\mathrm{Cr}$ & 350 & 17 & 14 & 11 & 7.5 \\
\hline $\mathrm{Co}-\mathrm{Cr}$ & 300 & $58-39$ & - & $18-12$ & 12 \\
\hline $\mathrm{Pt} / \mathrm{ZrO}{ }_{2}$ & 300 & 44 & 25 & 14 & 12 \\
\hline
\end{tabular}




\section{CHAPTER 3 EXPERIMENTAL SETUP AND PROCEDURE}

\subsection{Reactor Setup description}

The catalyst-testing unit used for the WGS reaction is shown in Figure 2. The unit is computer controlled using In Touch commercial software by Wonderware. The experimental setup consists of a stainless-steel reactor (from TW METALS), a high- pressure water syringe pump, a steam generator, a gas chromatograph (5890 HP-GC), and four mass-flow controllers (from Brooks Instruments). The reactor consists of a silica-lined stainless-steel tube of nominal diameter of $13 \mathrm{~mm}$ and nominal length of $0.6 \mathrm{~m}$ (25 in.), placed in a $0.45 \mathrm{~m}$ (18 in.) single-zone furnace (Applied Test Systems). A tube furnace capable of reaching $1100^{\circ} \mathrm{C}$ was used as a heat source for the reactor. A K-type thermocouple of $1 / 16$ " nominal diameter and 24 " nominal length with an inconel sheath ungrounded is inserted into the reactor to measure the temperature of the catalyst bed. The pressure in the reactor is monitored using a sensotec pressure transducer (model no. THE/743-011) with an operating range of $0-2000$ psig. Water is pumped continuously to a preheater using an ISCO 2350 stainless-steel high-performance liquid chromatograph (HPLC) pump. The temperature of the preheater is maintained at $170{ }^{\circ} \mathrm{C}$ in order to vaporize the water. A thermocouple is inserted at the centre of the preheater and the temperature is controlled by a temperature program controller. All feed lines from the pump outlet are heat-traced and insulated to ensure vaporization of the water when it mixes with other feed gases $(\mathrm{CO} / \mathrm{He} / \mathrm{Ar})$.

The reactant gases coming from the mass-flow controllers are well mixed with 


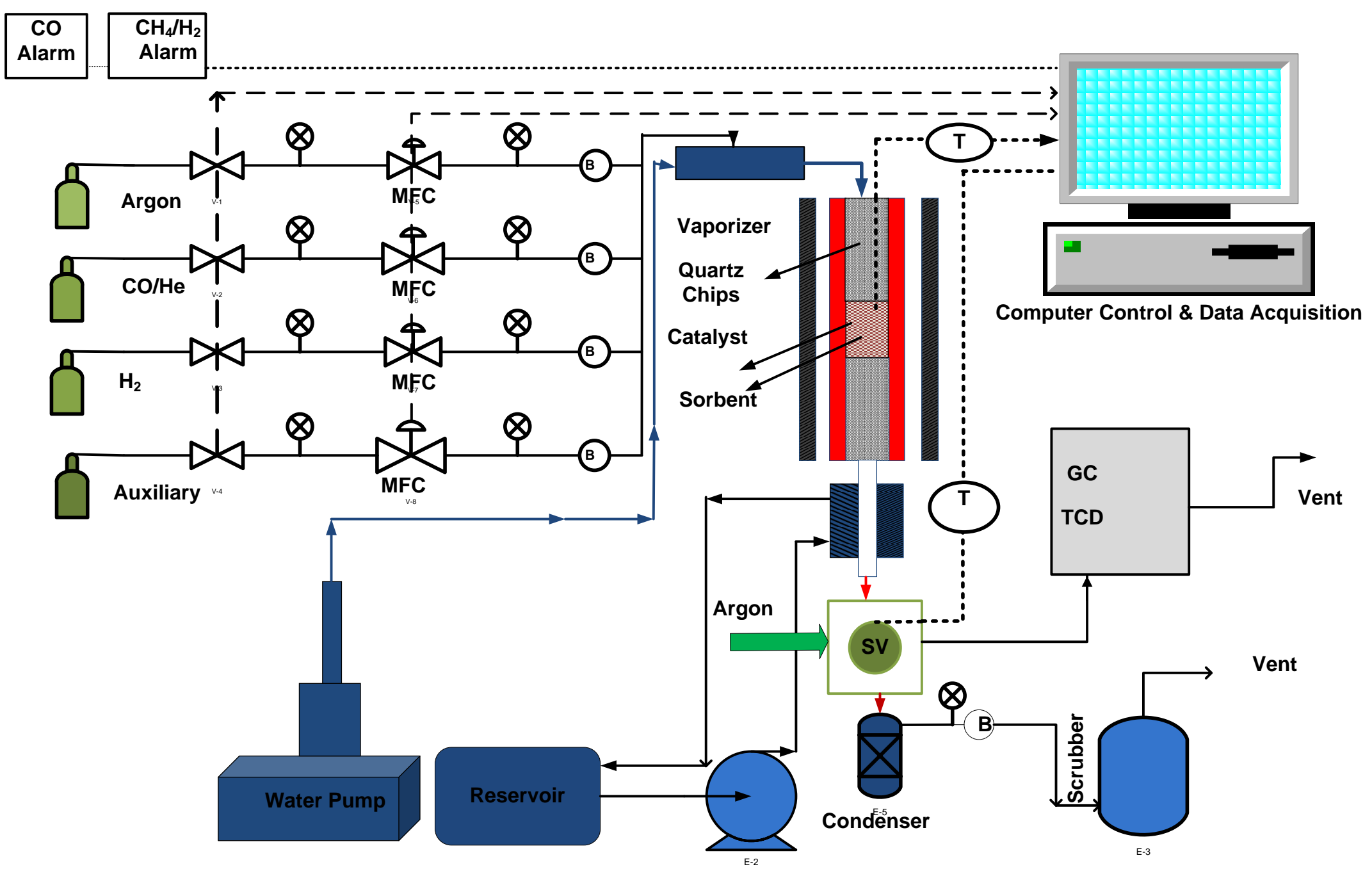

Figure 2. Schematic diagram of experimental setup for WGS reaction. 
steam in the preheater before being sent into the reactor. The feed lines between the preheater and the reactor inlet are maintained at $160^{\circ} \mathrm{C}$ by wrapping the line with heating tapes.

The product from the reactor outlet consists of $\mathrm{CO}, \mathrm{CO}_{2}, \mathrm{He}, \mathrm{Ar}, \mathrm{H}_{2}$ and $\mathrm{H}_{2} \mathrm{O}$. The product stream is analyzed using a six-port $0.5 \mathrm{ml}$ external-volume gassampling valve (Valco instrumentation Co. Inc) as shown in Figure 3. With the valve in position "A", sample flows through the external loop while the carrier gas (argon) flows directly to the chromatographic column. When the valve is in position "B", the sample contained in the sample loop and valve flow passage is injected onto the column. The sampling valve is maintained at reaction pressure and, at a temperature of $130^{\circ} \mathrm{C}$. A chiller with water as coolant is used between the reactor outlet and sampling valve to decrease the temperature of the hot gases from the reactor outlet to the temperature of the sampling valve. The exit gas from the sampling loop is sent to the condenser through the back-pressure regulator, used to maintain the required pressure in the reactor. Water is condensed in the condenser while other gases are released through the scrubber to the vent.

\subsection{HP 5890 Gas Chromatograph}

The products from the reactor outlet are continuously analyzed using the HP5890 gas chromatograph. A HayeSep-D packed column of $9 \mathrm{~m}$ length and 3.1 $\mathrm{mm}$ diameter is used for analysis. The packed column is connected to a thermalconductivity detector (TCD) to analyze the product gases quantitatively. The temperature of the GC oven is maintained at $150^{\circ} \mathrm{C}$ and the TCD temperature is maintained at $255^{\circ} \mathrm{C}$. Helium gas is used as internal standard gas while $\mathrm{Ar}$ is used 


\section{POSITION A}

POSITION B

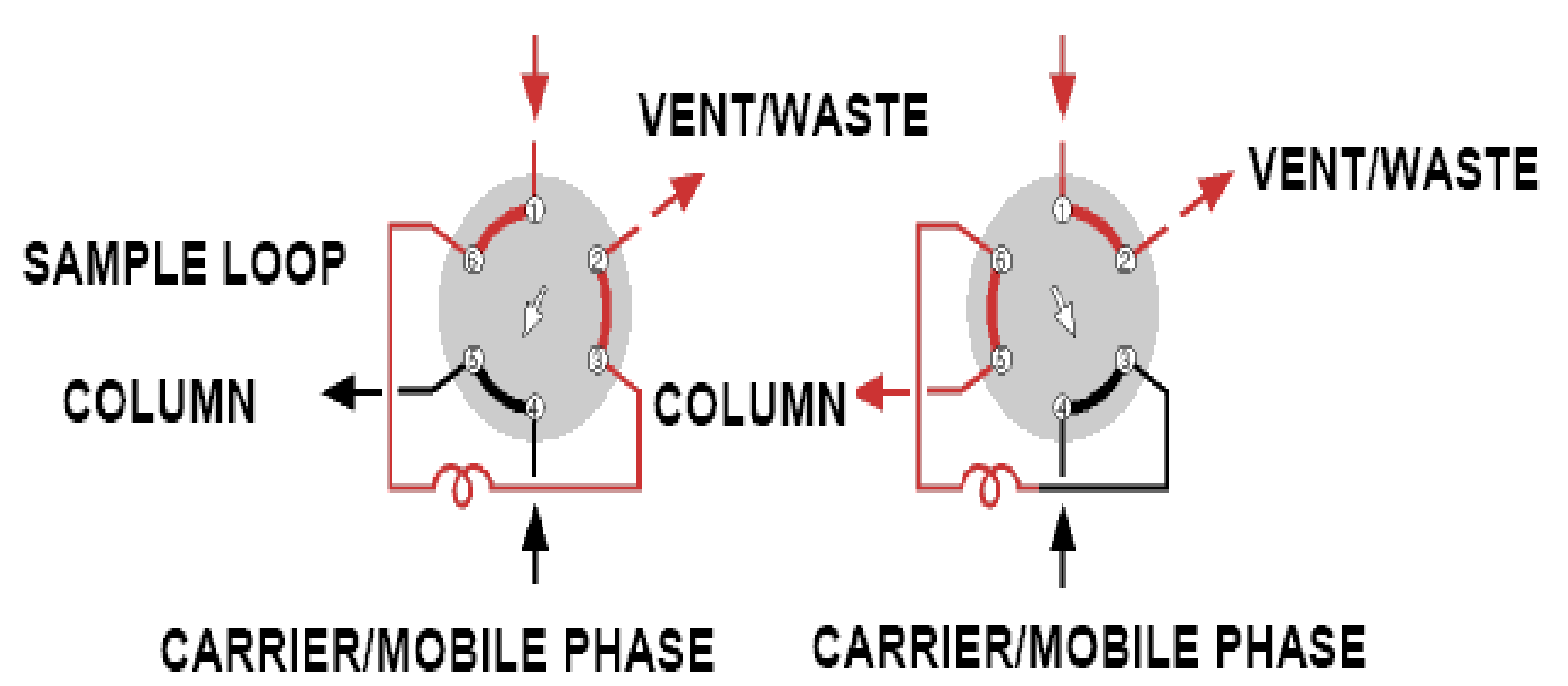

Figure 3. Schematic flow diagram of two-position six-port external volume sample injector (Valco Instruments Co. Inc). 
carrier gas. The operating conditions of the GC are given in Appendix B. The feed line between the sampling loop and the GC injection port is heated by wrapping the lines with heating (Omega Engineering. Inc) and insulation tapes.

\subsection{Calibrations}

\subsubsection{Calibration of Mass Flow Controllers}

As mentioned earlier, the reactor system has four lines for feed gases, each one independently controlled by a Brooks mass-flow controller (MFC). The massflow controllers are enclosed in an insulated styrofoam container to minimize the effect of any change in the room temperature on the calibration process. Initially, the gas flow rate for particular MFC is set to the maximum value and the system is allowed to reach steady state. Then, the outlet flows for different set points on each mass-flow meter are measured using a bubble flow meter. The same procedure is repeated for the other MFCs. The process is repeated each time prior to each experiment at the reaction conditions. The equations obtained from MFC calibration curves are given in Table 10.

Table 10. MFC Calibration equations for gases used in WGS reaction

$$
X=\text { set value }, Y=\text { measure flow rate. }
$$

\begin{tabular}{|c|c|c|c|}
\hline MFC & Gas & Equation & $\mathbf{R}^{2}$ \\
\hline $\mathrm{CH}_{4}$ & $\mathrm{H}_{2}$ & $\mathrm{Y}=1.3284 \mathrm{X}-41.947$ & 0.9991 \\
\hline $\mathrm{CO}_{2}$ & $\mathrm{CO} / \mathrm{He}$ & $\mathrm{Y}=1.2111 \mathrm{X}-89.774$ & 0.9999 \\
\hline $\mathrm{Ar}$ & $\mathrm{Ar}$ & $\mathrm{Y}=1.0188 \mathrm{X}+0.46666$ & 1 \\
\hline
\end{tabular}

\subsubsection{Calibration of HP5890 Gas Chromatograph}


As mentioned earlier, the products are analyzed online by the HewlettPackard $5890 \mathrm{GC}$, which provides quantitative analysis for $\mathrm{He}, \mathrm{CO}, \mathrm{CO}_{2}, \mathrm{H}{ }_{2} \mathrm{O}$, and $\mathrm{H}_{2}$ using the thermal-conductivity detector (TCD). All the gases are calibrated by injecting standard gas mixtures of known composition into the injector port from the sampling loop using the auto-injector for the GC. The GC operating conditions are given in Appendix B, while the details of the calculation and the calibration curves are presented in Appendix C.

\subsection{Catalyst and Sorbents}

A commercial high-temperature-shift (HTS) catalyst comprises of $\mathrm{Fe}_{2} \mathrm{O}_{3} / \mathrm{Cr}_{2} \mathrm{O}_{3} / \mathrm{CuO}$ with a composition of $88 \% / 12 \% / 2.5 \%$ (weight basis) is used for WGS reaction. $\mathrm{CaO}, \mathrm{CaO} / \mathrm{Ca}_{12} \mathrm{Al}_{14} \mathrm{O}_{33}\left(75 / 25\right.$ wt \%), and $\mathrm{CaO} / \mathrm{Ca}_{12} \mathrm{Al}_{14} \mathrm{O}_{33}(50 / 50$ wt $\%)$ sorbents are used for $\mathrm{CO}_{2}$ adsorption in the present study. $\mathrm{CaO}$ is obtained from Alfa Aesar. The sorbent $\mathrm{CaO} / \mathrm{Ca}_{12} \mathrm{Al}_{14} \mathrm{O}_{33}$ in various ratios is synthesized.

\subsubsection{Preparation of $\mathrm{CaO} / \mathrm{Ca}_{12} \mathrm{Al}_{14} \mathrm{O}_{33}$ sorbent in various ratios}

The preparation of $\mathrm{CaO} / \mathrm{Ca}_{12} \mathrm{Al}_{14} \mathrm{O}_{33}$ requires $\mathrm{CaO}$, aluminum nitrate $\left(\mathrm{Al}\left(\mathrm{NO}_{3}\right)_{3} \cdot 9 \mathrm{H}_{2} \mathrm{O}\right)$, 2-propanol, and water.

To prepare $40 \mathrm{~g}$ of the $\mathrm{CaO} / \mathrm{Ca}_{12} \mathrm{Al}_{14} \mathrm{O}_{33}(75 / 25 \mathrm{wt} \%)$ mixture, initially, 34.85 $\mathrm{g}$ of powdered calcium oxide is added to $760 \mathrm{ml}$ of water. When $\mathrm{CaO}$ is added to water, the hydration of calcium oxide takes place according to:

$$
\mathrm{CaO}+\mathrm{H}_{2} \mathrm{O} \Leftrightarrow \mathrm{Ca}(\mathrm{OH})_{2}
$$


Because of the volume increase from $\mathrm{CaO}\left(16.9 \mathrm{~cm}^{3} / \mathrm{mol}\right)$ to $\mathrm{Ca}(\mathrm{OH})_{2}(33$ $\mathrm{cm}^{3} / \mathrm{mol}$ ) and the expansion caused by the large quantity of heat released in hydration, ultra-fine $\mathrm{Ca}(\mathrm{OH})_{2}$ particles can be generated from the cracking and refining of $\mathrm{CaO}$ particles. ${ }^{58}$ The formed solution of $\mathrm{Ca}(\mathrm{OH})_{2}$ is stirred for 2 hours at $75^{\circ} \mathrm{C}$.

In the second step, a solution of aluminum nitrate and 2-propanol is prepared by adding $37.89 \mathrm{~g}$ of aluminum nitrate to $150 \mathrm{ml}$ of 2-propanol solvent. Then the solution of aluminum nitrate and 2-propanol is added to the solution of $\mathrm{Ca}(\mathrm{OH})_{2}$, stirred at a constant temperature of $75{ }^{\circ} \mathrm{C}$. The addition of 2-propanol makes the particle size distribution of hydration product $\mathrm{Ca}(\mathrm{OH})_{2}$ more uniform in the solution. The water in the sample is removed via drying in air at $120^{\circ} \mathrm{C}$ overnight. The resulting cake is calcined at $500^{\circ} \mathrm{C}$. Calcination at $500{ }^{\circ} \mathrm{C}$ leads to the formation of large aggregates of a mixture of calcium oxide and aluminum oxide according to:

$$
\begin{gathered}
\mathrm{Ca}(\mathrm{OH})_{2} \Leftrightarrow \mathrm{CaO}+\mathrm{H}_{2} \mathrm{O} \\
4 \mathrm{~A}\left(\mathrm{NO}_{3}\right)_{3} \cdot 9 \mathrm{H}_{2} \mathrm{O} \Leftrightarrow 2 \mathrm{Al}_{2} \mathrm{O}_{3}+12 \mathrm{NO}_{2}+3 \mathrm{O}_{2}+9 \mathrm{H}_{2} \mathrm{O}
\end{gathered}
$$

In the third step, wet paste is obtained by adding water to the mixture of large aggregates of $\mathrm{CaO}$ and $\mathrm{Al}_{2} \mathrm{O}_{3}$ produced by calcination at $500{ }^{\circ} \mathrm{C}$. The addition of water leads to the hydration of $\mathrm{CaO}$ to $\mathrm{Ca}(\mathrm{OH})_{2}$. Because of the volume increase from $\mathrm{CaO}$ to $\mathrm{Ca}(\mathrm{OH})_{2}$ and the expansion caused by the exothermic hydration of $\mathrm{CaO}$, the aggregates crack and swell, and the regular hexagonal crystalloids of $\mathrm{Ca}(\mathrm{OH})_{2}$ are generated. ${ }^{58}$

Finally, the formed paste is dried at $120^{\circ} \mathrm{C}$ for 2 hours and calcined in air at $900{ }^{\circ} \mathrm{C}$ for 2 hours. During this calcination, regular hexagonal $\mathrm{Ca}(\mathrm{OH})_{2}$ crystalloids 
decompose into $\mathrm{CaO}$ and $\mathrm{H}_{2} \mathrm{O}$, and transform into a porous network. Then $\mathrm{Al}_{2} \mathrm{O}_{3}$ reacts with $\mathrm{CaO}$ proportionally and generates a new kind of binder, mayenite $\left(\mathrm{Ca}_{12} \mathrm{Al}_{14} \mathrm{O}_{33}\right)$ according to: ${ }^{58}$

$$
7 \mathrm{CaO}+12 \mathrm{~A}_{2} \mathrm{O}_{3} \Leftrightarrow \mathrm{Ca}_{12} \mathrm{Al}_{14} \mathrm{O}_{33}
$$

The binder mayenite $\left(\mathrm{Ca}_{12} \mathrm{Al}_{14} \mathrm{O}_{33}\right)$ is distributed uniformly among the $\mathrm{CaO}$ particles and a mixture of $\mathrm{CaO} / \mathrm{Ca}_{12} \mathrm{Al}_{14} \mathrm{O}_{33}(75 / 25 \mathrm{wt} \%)$ is formed.

To prepare $\mathrm{CaO} / \mathrm{Ca}_{12} \mathrm{Al}_{14} \mathrm{O}_{33}(50 / 50$ wt \%), a similar procedure is followed. The following amounts are used; $29.07 \mathrm{~g}$ of $\mathrm{CaO}, 75.79 \mathrm{~g}$ of $\mathrm{Al}\left(\mathrm{NO}_{3}\right)_{3} \cdot 9 \mathrm{H}_{2} \mathrm{O}, 760 \mathrm{ml}$ of distilled water, and $150 \mathrm{ml}$ of 2-propanol.

\subsection{Catalyst and sorbent characterization}

The interpretation of catalyst performance depends on the study of physical, chemical, and structural properties of the catalyst and on measurement of correlations between these characteristics and catalyst performance. The important catalytic properties of the synthesized catalysts are the catalyst composition, the BET surface area and the pore size distribution, metal dispersion, reducibility, crystal structure, surface morphology and oxidation state of the metals. BET surface area measurements, pore size distribution measurements, temperature-programmed desorption /reduction (TPD/TPR), and X-ray diffraction (XRD) are used for characterization of the catalyst.

\subsubsection{XRD measurement}

$\mathrm{XRD}$ is mainly useful for the determination of change in crystallinity and phase transformation of species present in the HTS catalyst and sorbents during 
calcination and reduction steps. X-ray diffraction analysis was performed at room temperature on a Rigaku X-ray diffractometer with rotating anode generators and a monochromatic detector using CuKa radiation (1.5418Á).

Figure 4 shows the XRD pattern of the commercial $\mathrm{HTS}\left(\mathrm{Fe}_{2} \mathrm{O}_{3} / \mathrm{Cr}_{2} \mathrm{O}_{3} / \mathrm{CuO}\right)$ catalyst. Before XRD measurements, the HTS catalyst was calcined at $450{ }^{\circ} \mathrm{C}$ in the presence of air overnight. The peaks at $24.1378^{\circ}, 33.1523^{\circ}, 35.6112^{\circ}, 40.8544^{\circ}$, $49.4791^{\circ}, 54.0892^{\circ}, 57.4276^{\circ}, 62.449^{\circ}, 63.9891^{\circ}$, and $72.2603^{\circ}$ in the XRD pattern of the fresh HTS catalyst correspond well to the reference data of $\mathrm{Fe}_{2} \mathrm{O}_{3}$ from the International Centre for Diffraction Data (ICDD). The XRD result explains that the fresh HTS catalyst is primarily comprised of $\mathrm{Fe}_{2} \mathrm{O}_{3} \cdot \mathrm{Cr}_{2} \mathrm{O}_{3}$ and $\mathrm{CuO}$ crystalline phases are not prominent in the XRD pattern of the calcined HTS catalyst. However, the $\mathrm{Cu}$ and $\mathrm{Cr}$ could exist in solid solution within the hematite $\left(\mathrm{Fe}_{2} \mathrm{O}_{3}\right)$ lattice upon the catalyst preparation.

The XRD image of calcium oxide is shown in Figure 5. The peaks at $29.44^{\circ}$, $32.257^{\circ}, 37.418^{\circ}, 53.913^{\circ}, 64.20^{\circ}, 67.437^{\circ}$, and $88.590^{\circ}$ match well to the reference data of calcium oxide from ICDD. No other phases are found.

The XRD patterns of the synthesized sorbents $\mathrm{CaO} / \mathrm{Ca}_{12} \mathrm{Al}_{14} \mathrm{O}_{33}$ in the ratios $75 / 25$, and $50 / 50$ are shown in Figures $6 \& 7$ respectively. The peaks at $32.18^{\circ}$, $37.319^{\circ}, 53.817^{\circ}, 67.296^{\circ}, 79.627^{\circ}$, and $88.65^{\circ}$ in Figures $6 \& 7$ match well to the reference data of $\mathrm{CaO}$ from $I C D D$, with the peak at $37.319^{\circ}$ being the most prominent. The peaks at $18.09^{\circ}, 20.91^{\circ}, 23.46^{\circ}, 27.79^{\circ}, 28.741^{\circ}, 33.396^{\circ}, 36.073^{\circ}$, $38.227^{\circ}, 41.21^{\circ}, 46.64^{\circ}, 55.21^{\circ}, 56.40^{\circ}$, and $57.46^{\circ}$ match well to the reference data of mayenite $\left(\mathrm{Ca}_{12} \mathrm{Al}_{14} \mathrm{O}_{33}\right)$, with the peak at $18.09^{\circ}$ being the most prominent. The 


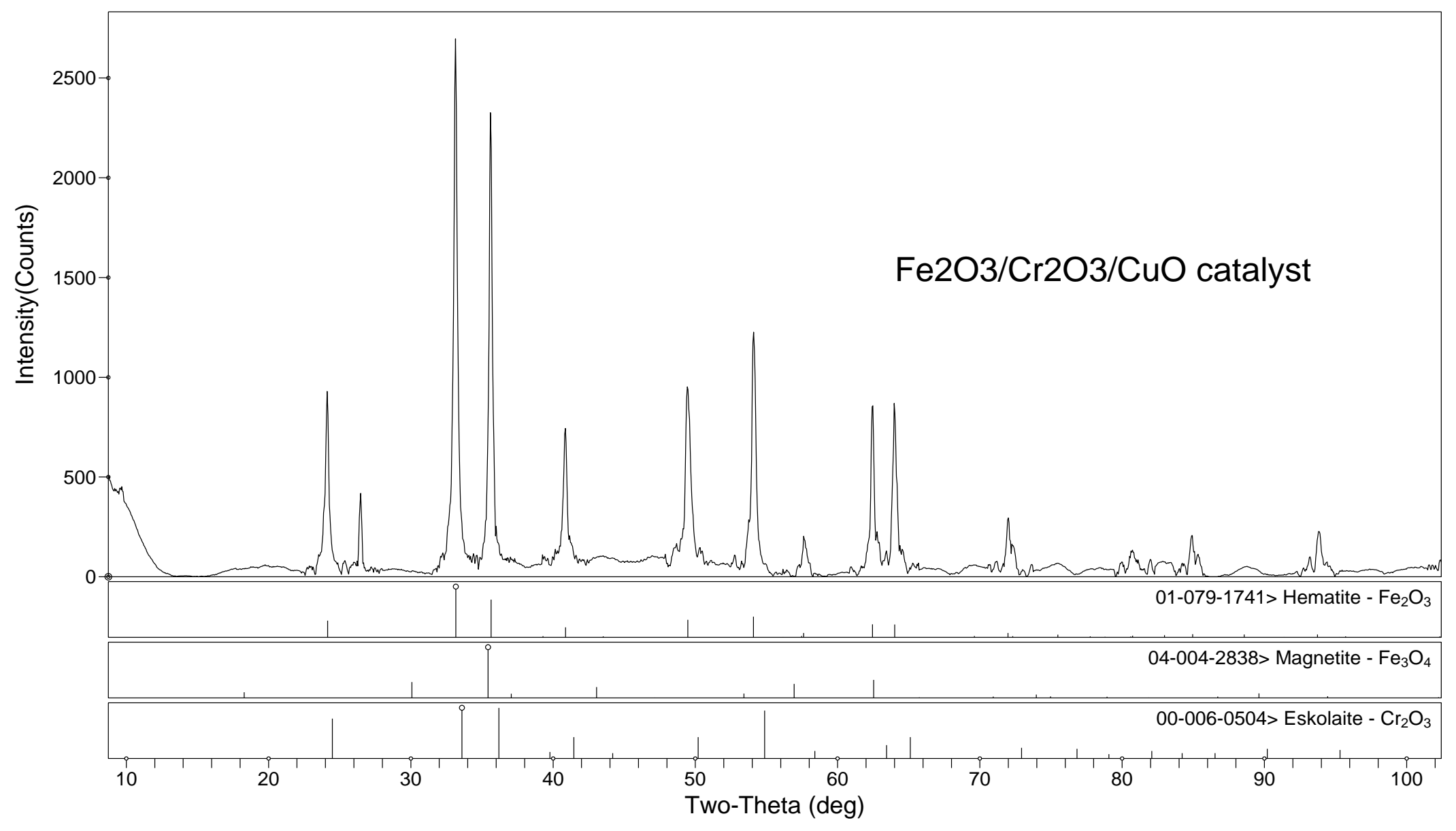

Figure 4. XRD pattern of $\mathrm{HTS}\left(\mathrm{Fe}_{2} \mathrm{O}_{3} / \mathrm{Cr}_{2} \mathrm{O}_{3} / \mathrm{CuO}\right)$ catalyst. 


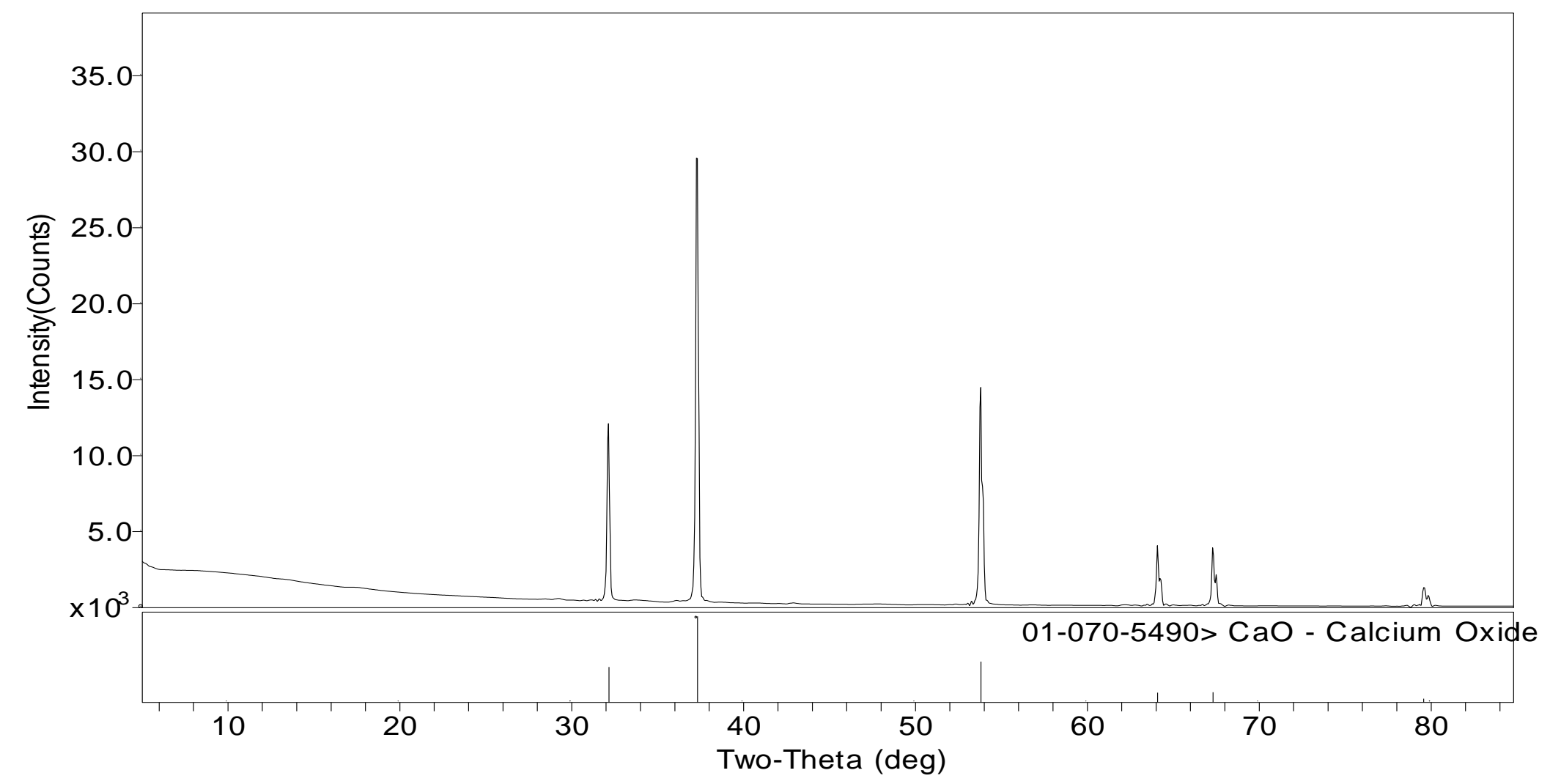

Figure 5. XRD pattern of calcium oxide. 


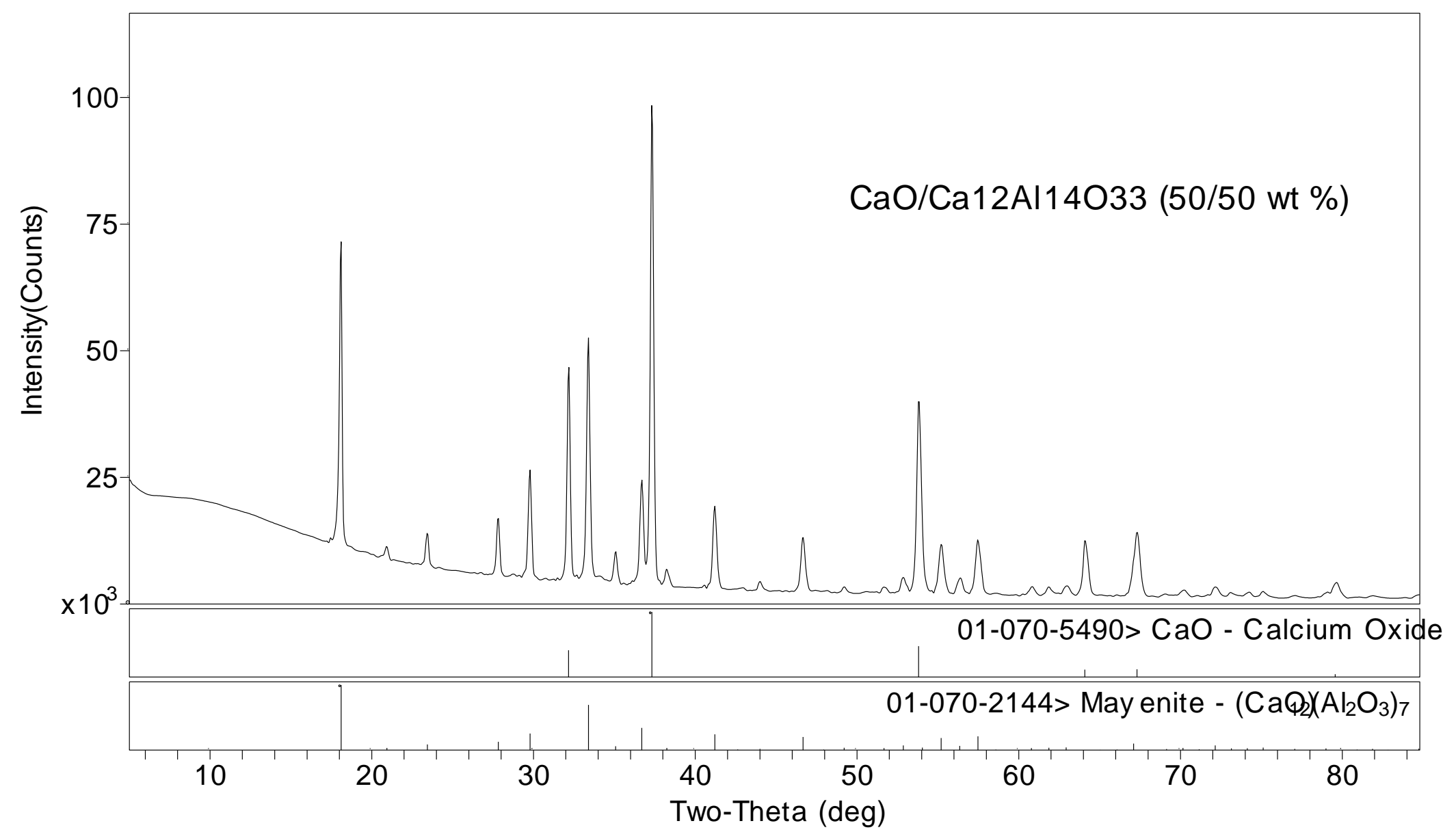

Figure 6. XRD pattern of $\mathrm{CaO} / \mathrm{Ca}_{12} \mathrm{Al}_{14} \mathrm{O}_{33}(50 / 50$ wt \%) sorbent. 


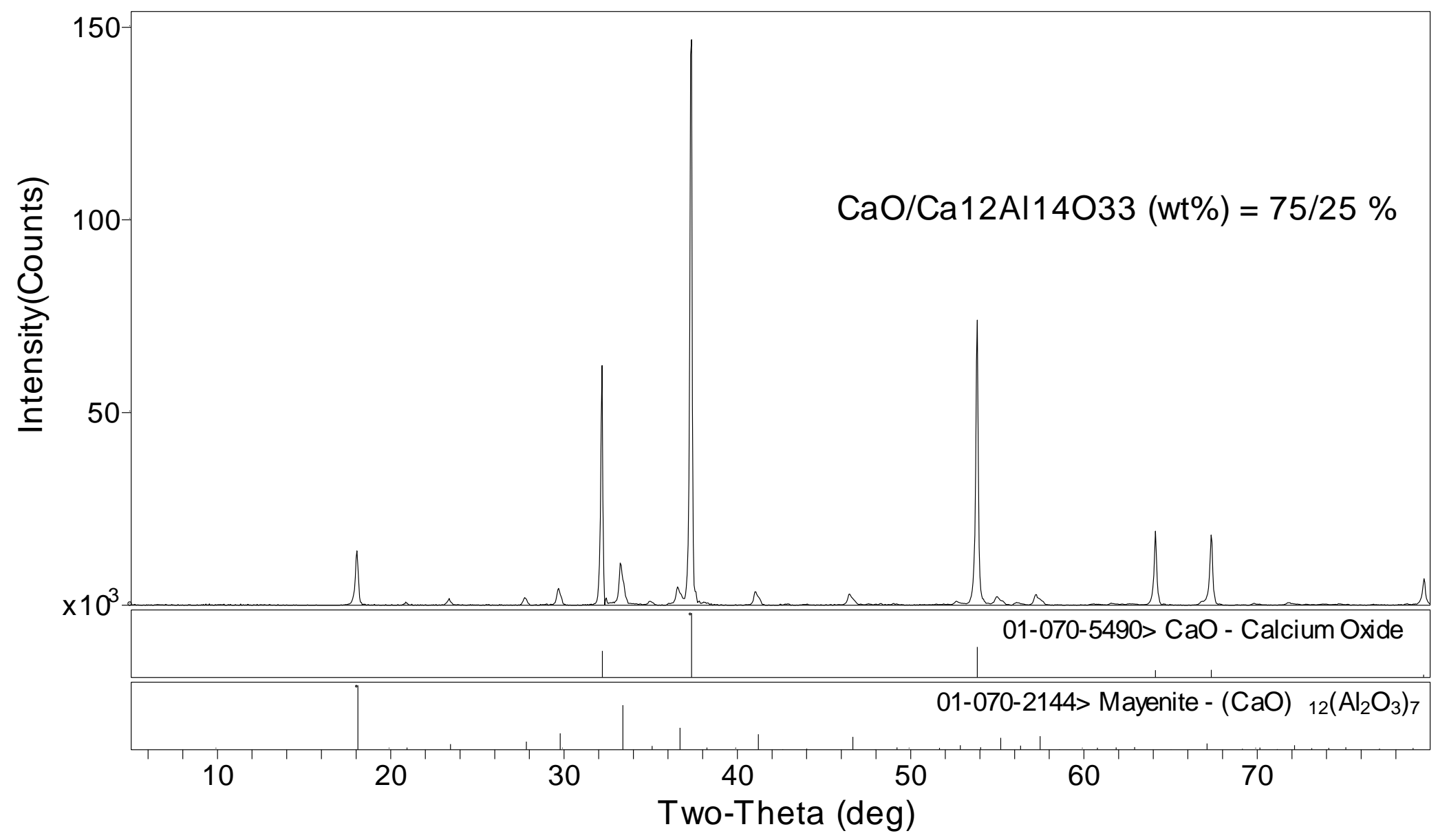

Figure 7. XRD pattern of $\mathrm{CaO} / \mathrm{Ca}_{12} \mathrm{Al}_{14} \mathrm{O}_{33}(75 / 25$ wt \%) sorbent. 
XRD patterns of the $\mathrm{CaO} / \mathrm{Ca}_{12} \mathrm{Al}_{14} \mathrm{O}_{33}$ mixtures, both $75 / 25$ wt $\%$ and $50 / 50$ wt $\%$ indicate that they contain mainly calcium oxide and mayenite $\left(\mathrm{Ca}_{12} \mathrm{Al}_{14} \mathrm{O}_{33}\right)$. No other phases are found. The major peak for $\mathrm{CaO}\left(37.319^{\circ}\right)$ is much more pronounced relative to the major peak for mayenite $\left(18.09^{\circ}\right)$ in Figure 7 relative to Figure 6 , as expected.

\subsubsection{Scanning electron microscopy}

The surface morphology of the commercial HTS catalyst $\left(\mathrm{Fe}_{2} \mathrm{O}_{3} / \mathrm{Cr}_{2} \mathrm{O}_{3} / \mathrm{CuO}\right)$ is obtained using a Hitachi S-4700 scanning electron microscope (SEM), with X-ray energy dispersive spectroscopy (EDS) used to determine local elemental composition. The sample is placed on conductive double-faced tape and then placed in the Hitachi S-4700.

As shown in Figure 8, the HTS catalyst is highly porous, with a grain-like structure. The main elements present in the HTS catalyst are shown in Figure 9 as chromium, iron, copper, oxygen, and carbon. The peak corresponding to gold is due to the use of gold as conductive material for specimen coating.

\subsubsection{Brunauer-Emmett-Teller (BET) Surface Area Measurement}

The most common method for measuring the surface area of HTS catalyst is the Brunauer, Emmett and Teller (BET) method. The BET surface area and pore volume of the calcined HTS catalyst $\left(\mathrm{Fe}_{2} \mathrm{O}_{3} / \mathrm{Cr}_{2} \mathrm{O}_{3} / \mathrm{CuO}\right)$ are measured by the isothermal adsorption of $\mathrm{N}_{2} 77 \mathrm{~K}$ in a Coulter Omnisorp 360 system. Prior to the adsorption measurements, the sample is degassed under a vacuum at $300{ }^{\circ} \mathrm{C}$ for 2 hours. The surface area and pore volume of the HTS catalyst are given in Table 11. 
Table 11. Morphological properties of HTS catalyst

\begin{tabular}{|c|c|c|c|}
\hline $\begin{array}{l}\text { HTS Catalyst } \\
\text { HIFUELW210 }\end{array}$ & $\begin{array}{c}\text { Surface area } \\
\left(\mathbf{m}^{2} / \mathbf{g}\right)\end{array}$ & $\begin{array}{c}\text { Pore volume } \\
(\mathbf{m l} / \mathbf{g})\end{array}$ & $\begin{array}{c}\text { Average pore } \\
\text { diameter }\left(\mathbf{A}^{\circ}\right)\end{array}$ \\
\hline & 193.09 & 0.21 & 169 \\
\hline$\left(\mathrm{Fe}_{2} \mathrm{O}_{3} / \mathrm{Cr}_{2} \mathrm{O}_{3} / \mathrm{CuO}\right)$ & & & \\
\hline
\end{tabular}

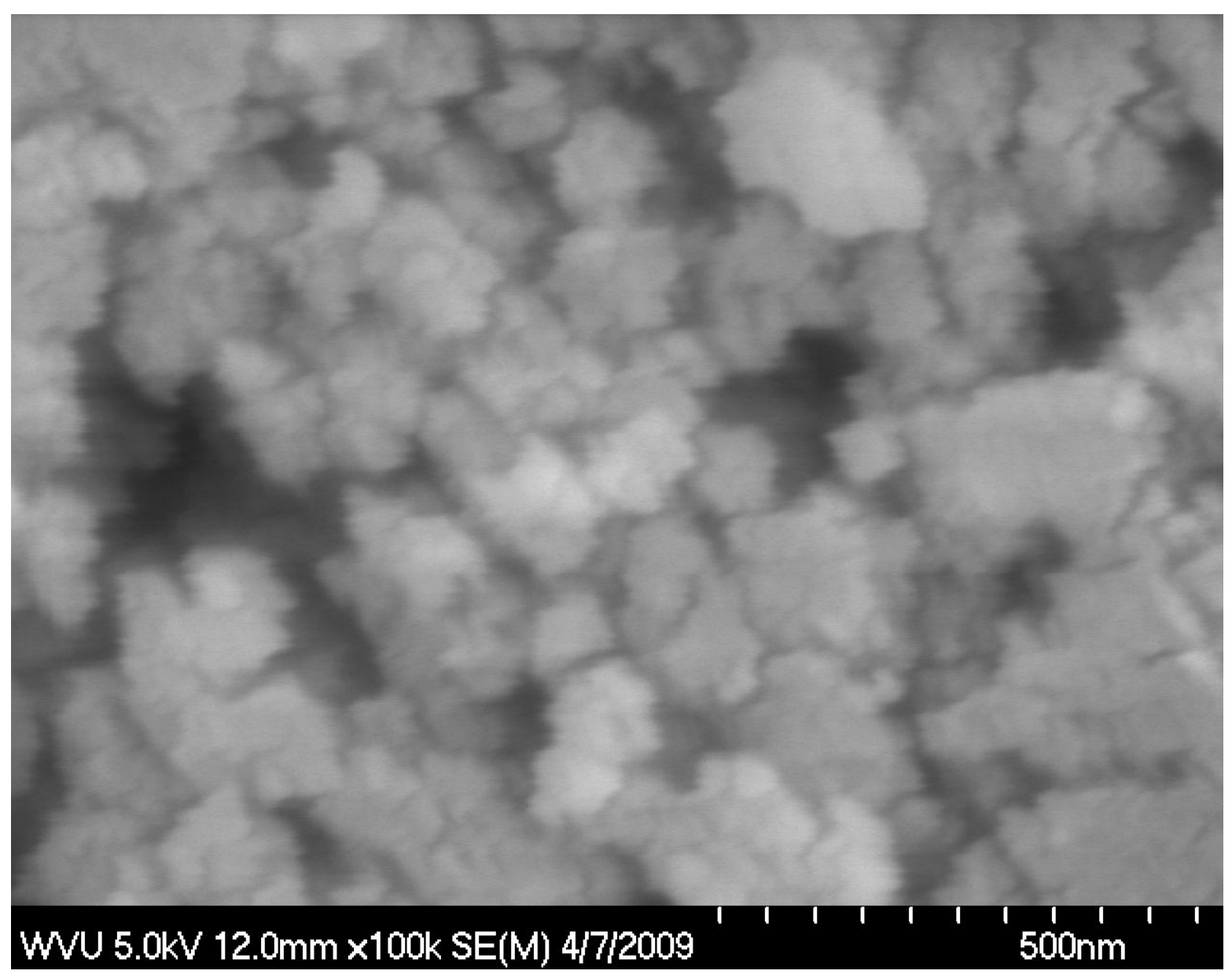

Figure 8. SEM image of $\mathrm{HTS}\left(\mathrm{Fe}_{2} \mathrm{O}_{3} / \mathrm{Cr}_{2} \mathrm{O}_{3} / \mathrm{CuO}\right)$ catalyst. 


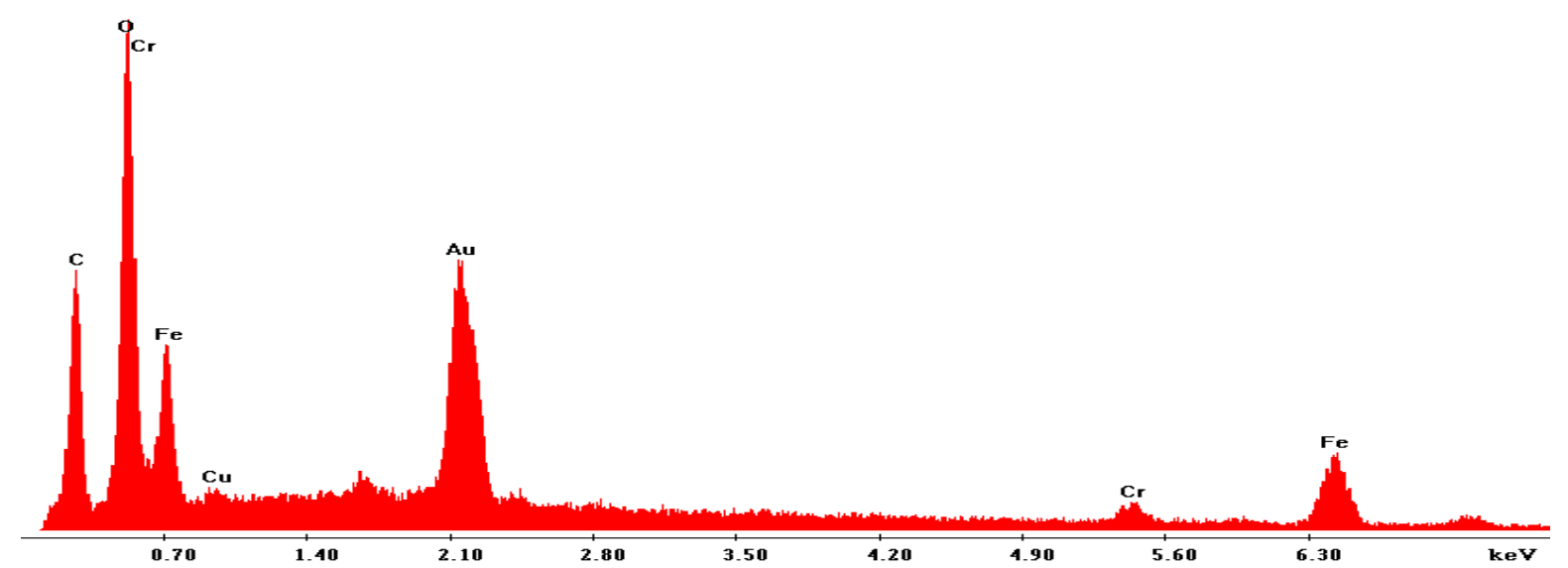

Figure 9. EDS spectrum of $\mathrm{HTS}\left(\mathrm{Fe}_{2} \mathrm{O}_{3} / \mathrm{Cr}_{2} \mathrm{O}_{3} / \mathrm{CuO}\right)$ catalyst.

\subsection{Pelletization of HTS catalyst and sorbents}

The powdered calcium oxide, $\mathrm{CaO} / \mathrm{Ca}_{12} \mathrm{Al}_{14} \mathrm{O}_{33}$ (75/25 wt \%, 50/50 wt \%), and HTS catalyst $\left(\mathrm{Fe}_{2} \mathrm{O}_{3} / \mathrm{Cr}_{2} \mathrm{O}_{3} / \mathrm{CuO}\right)$ were each pelletized by applying a pressure of 10 tons for 5 minutes. The formed HTS catalyst pellets were crushed and sieved into grains of $0.84-0.042 \mathrm{~mm}$ (20-40 mesh) in size. Sorbents were crushed and sieved into particles of $0.42-0.25 \mathrm{~mm}(40-60)$ in size.

\subsection{Pretreatment of the $\mathrm{HTS}\left(\mathrm{Fe}_{2} \mathrm{O}_{3} / \mathrm{Cr}_{2} \mathrm{O}_{3} / \mathrm{CuO}\right)$ catalyst and sorbents}

The commercial HTS $\left(\mathrm{Fe}_{2} \mathrm{O}_{3} / \mathrm{Cr}_{2} \mathrm{O}_{3} / \mathrm{CuO}\right)$ catalyst obtained from Alfa Aesar was calcined in air at $450^{\circ} \mathrm{C}$ for 3 hours. The reduction process used for the catalyst involves two steps. In the first step, the HTS catalyst was heated up to $120^{\circ} \mathrm{C}$ with a ramp rate of $5{ }^{\circ} \mathrm{C} / \mathrm{min}$ in the presence of Ar. During this heating, any moisture content on the catalyst was evaporated. In the second step, the catalyst was 
reduced in the presence of $\mathrm{H}_{2} / \operatorname{Ar}(10 / 90 \%)$ with a ramp rate of $5{ }^{\circ} \mathrm{C} / \mathrm{min}$ up to 300 ${ }^{\circ} \mathrm{C}$. The catalyst was held at $300^{\circ} \mathrm{C}$ for 3 hours. A total flow of $170 \mathrm{sccm}$ was used for reduction. Prior to each experiment, the catalyst was purged with a flow rate of $200 \mathrm{sccm}$ for 2 hours in order to remove any traces of hydrogen on the surface of the catalyst.

The $\mathrm{CaO}$ sorbent is calcined in air at $600{ }^{\circ} \mathrm{C}$ for 2 hours while the $\mathrm{CaO} / \mathrm{Ca}_{12} \mathrm{Al}_{14} \mathrm{O}_{33}(75 / 25 \mathrm{wt} \%$ and $50 / 50 \mathrm{wt} \%)$ sorbent is calcined in air at $900{ }^{\circ} \mathrm{C}$ for 1.5 hours.

\subsection{Feed gas compositions}

The gases used for all experiments are 100\% ultrahigh-pure argon and $\mathrm{CO} / \mathrm{He}(95 / 5 \%)$. The $\mathrm{H}_{2} \mathrm{O}$ is pumped by using a HPLC liquid pump. The reaction mixture used for the WGS reaction alone comprised of $\mathrm{CO}, \mathrm{Ar}, \mathrm{H}_{2} \mathrm{O}$, and $\mathrm{He}$ with a ratio of 1:2:1.44:0.00055. A steam-to-CO ratio of 2 was used for the study of effect of temperature on CO conversions. A total flow of $200 \mathrm{sccm}$ was used for each experiment.

For the combined WGS and carbonation reactions, the feed gas composition $\mathrm{CO} / \mathrm{H}_{2} \mathrm{O} / \mathrm{Ar} / \mathrm{He}$ of $1 / 2 / 2.7 / 0.0524$ was used. A total feed rate of $380 \mathrm{sccm}$ was used for each experiment. The combined reactions are conducted in two modes. In the first mode, the HTS catalyst and sorbent are mixed together and placed in the reactor as a single bed. This concept is also called sorption-enhanced water-gas shift reaction (SEWGS). In the second mode, the HTS catalyst and the sorbent are kept as separate beds separated by quartz chips. This is to understand better the 
role of the sorbent in the sorption-enhanced process. The schematic diagrams of the two modes are shown in Figure 10.

\subsection{Reactor loading}

The stainless-steel reactor tube was washed with soap solution and dried using air. For the WGS reaction, $200 \mathrm{mg}$ of the catalyst was used for each experiment. For both modes of the combined WGS and carbonation reactions, a catalyst weight of $200 \mathrm{mg}$ and a sorbent weight of $2.5 \mathrm{~g}$ are used. For these experiments, the amounts of catalyst and sorbent were not varied. The catalyst (and sorbent) were diluted with $1 / 32$ " quartz chips. Approximately $42 \mathrm{~g}$ of the $1 / 16$ " quartz chips were used for each experiment. The fresh quartz chips were washed and dried before loading into the reactor. About half of the quartz chips were inserted into the top of the reactor, over a plug of quartz wool (used because of its stability up to $1000^{\circ} \mathrm{C}$ and its inert nature). The catalyst system $(0.2 \mathrm{~g}$ of catalyst and $0.8 \mathrm{~g}$ of fine quartz chips for the catalyst-alone set up, and $0.2 \mathrm{~g}$ catalyst, $2.5 \mathrm{~g}$ sorbent, and $5.8 \mathrm{~g}$ of quartz chips for the combined mode) was inserted into the centre of the reactor over quartz wool. A thermocouple was inserted into the reactor such that the end of the thermocouple touched the bed of the catalyst-chips system at the centre. The

remaining part of the reactor was filled with rest of the quartz chips. The top end of reactor exit was covered with a second plug of the quartz wool and the reactor was placed into the furnace.

The reactor system was tested for leaks by flowing argon gas under a pressure of 40 psig at room temperature. To avoid the condensation of steam $\left(\mathrm{H}_{2} \mathrm{O}\right)$ in the feed lines between the evaporator and reactor inlet, the lines 


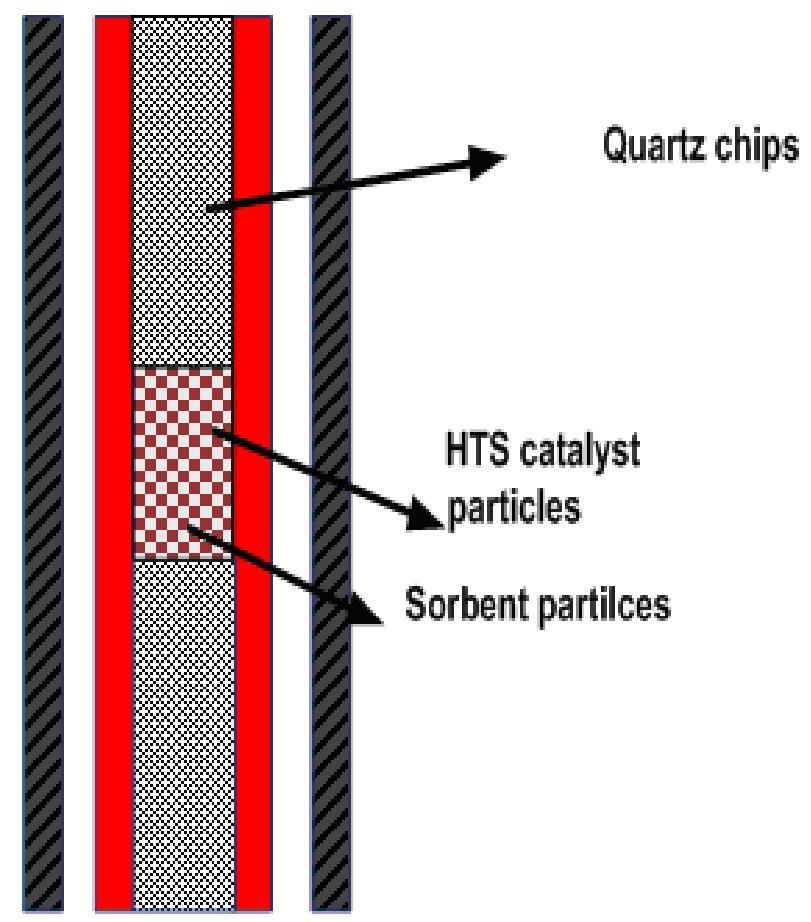

1

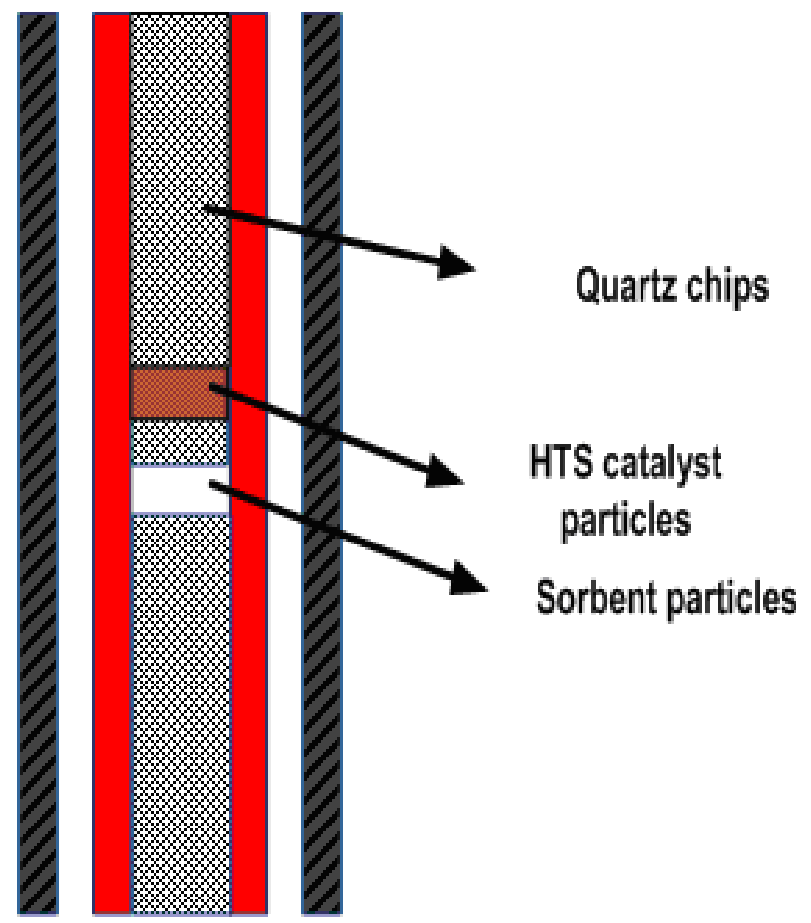

2

Figure 10. Schematic diagram of reactor with (1) HTS catalyst and sorbent mixture, (2) HTS catalyst and sorbent separated with chips. 
were heat-traced and maintained at $150^{\circ} \mathrm{C}$ using heating tapes with insulation into the reactor.

\subsection{Blank tests}

Blank tests were conducted to study the activity of WGS reaction in the absence of the catalyst or sorbent. In this case, the tube reactor was totally filled with $1 / 16$ " quartz chips without catalyst. The pressure in the reactor was maintained at $1 \mathrm{~atm}$ for all the blank runs.

\subsection{Study of catalytic activity of sorbents towards WGS reaction}

Experiments were conducted to study the catalytic activity of the sorbents $\mathrm{CaO}$ and $\mathrm{CaO} / \mathrm{Ca}_{12} \mathrm{Al}_{14} \mathrm{O}_{33}$, both $75 / 25 \mathrm{wt} \%$, and $50 / 50$ wt $\%$, towards WGS and $\mathrm{CO}$ conversion without any $\mathrm{HTS}$ catalyst at $500^{\circ} \mathrm{C}$. Sorbent particles of $40-60$ mesh were used for each experiment. $2.5 \mathrm{~g}$ of the sorbent was used for each experiment. The pressure in the reactor was maintained at $1 \mathrm{~atm}$ for all the experiments.

\subsection{Study of WGS reaction}

The WGS reaction was conducted using the high-temperature shift (HTS) catalyst $\left(\mathrm{Fe}_{2} \mathrm{O}_{3} / \mathrm{Cr}_{2} \mathrm{O}_{3} / \mathrm{CuO}\right)$ obtained from Alfa Aesar. Catalyst particles of 20-40 mesh were used for all the experiments. $0.2 \mathrm{~g}$ of HTS catalyst was used for each experiment. The reactor outlet gas mixture comprised of $\mathrm{CO}, \mathrm{H}_{2} \mathrm{O}, \mathrm{CO}_{2}, \mathrm{H}_{2}, \mathrm{He}$, and Ar was continuously measured using the GC. The reactions were conducted at temperatures ranging from $350-600{ }^{\circ} \mathrm{C}$, and with two different steam-to-CO ratios $\left(\mathrm{H}_{2} \mathrm{O} / \mathrm{CO}\right), 1: 1$ and 2:1. The pressure in the reactor was maintained at $1 \mathrm{~atm}$ for all the runs. 


\subsection{Combined WGS and carbonation reactions in two different modes}

The combined WGS and carbonation reactions in two different modes (described in Section 2.6.3 and 2.10) were conducted using the same fixed-bed reactor setup described earlier. A commercial HTS catalyst comprised of $\mathrm{Fe}_{2} \mathrm{O}_{3} / \mathrm{Cr}_{2} \mathrm{O}_{3} / \mathrm{CuO}$ was used. $\mathrm{CaO}$ and $\mathrm{CaO} / \mathrm{Ca}_{12} \mathrm{Al}_{14} \mathrm{O}_{33}$ in various ratios $(75 / 25$ wt $\%$ and $50 / 50$ wt \%) were used as sorbents in this study. Typically, $0.2 \mathrm{~g}$ of the catalyst and $2.5 \mathrm{~g}$ of the sorbent were used for each experiment.

The experiments were conducted at $500{ }^{\circ} \mathrm{C}$ with a $\mathrm{H}_{2} \mathrm{O} / \mathrm{CO}$ ratio of 2 at $1 \mathrm{~atm}$ pressure. A total gas flow rate of $380 \mathrm{sccm}$ with a composition of $\mathrm{CO}-17.54 \%$, He0.92\%, $\mathrm{H}_{2} \mathrm{O}-34.67 \%$, and $\mathrm{Ar}-46.87 \%$ was used for each experiment.

Before each experiment, the $\mathrm{HTS}\left(\mathrm{Fe}_{2} \mathrm{O}_{3} / \mathrm{Cr}_{2} \mathrm{O}_{3} / \mathrm{CuO}\right)$ catalyst was reduced using a gas mixture of $\mathrm{H}_{2} / \operatorname{Ar}(10 / 90 \%)$ for 2 hours. Then the system was flushed with argon (100\%) with a flow rate of $200 \mathrm{sccm}$ to remove any traces of hydrogen present on the catalyst surface.

\subsection{Safety considerations}

The safety requirements are continuously reviewed. The most important areas of concern deal with high operating temperatures, toxicity of chemicals, compressed cylinders, electrical connections, and flammability of gases. Since the reactions are operated at high temperature, safety goggles, lab coat, and gloves are used while working near the equipment. Latex gloves are used while handling chemicals. Compressed cylinders are always secured firmly and valve protective caps are kept in place when cylinders are not in use. 
Chemicals are stored in proper conditions and the iron/ chromium/ copper catalyst used in this study is tightly sealed in a container and stored in a cool, dry place.

Hydrogen, carbon monoxide, and methane are highly flammable. Therefore, these gases are always kept away from a heat source. The computer continuously monitors flows of reactive gases, hood velocity, ambient hood temperature, reactor temperature, pressure, and electric power. The quality of air inside the laboratory area is controlled using gas sensors which are connected to the emergency alarms. The laboratory is provided with chemical hoods, fire extinguishers, chemical safety showers, chemical split kit, and eye wash stations. Material Safety Data Sheets (MSDSs) have been obtained for all the chemicals used in the laboratory and are placed in accessible place in the laboratory. Food and beverages are always avoided while working in the laboratory. 


\section{CHAPTER 4 RESULTS AND DISCUSSION}

\subsection{Thermodynamics of WGS reaction}

The equilibrium constant $\left(\mathrm{K}_{\mathrm{e}}\right)$ of the WGS reaction (1) is expressed by

$$
K_{e}=\frac{X_{e}^{2}}{\left(1-X_{e}\right)\left(M-X_{e}\right)}
$$

where $\mathrm{X}_{\mathrm{e}}$ is the equilibrium conversion, $\mathrm{K}_{\mathrm{e}}$ is the equilibrium constant, and $\mathrm{M}$ is the number of moles of water per moles of $\mathrm{CO}$ at the inlet. The equilibrium constant $\left(\mathrm{K}_{\mathrm{e}}\right)$ of the WGS reaction in the temperature range of $350-1000^{\circ} \mathrm{C}$ was calculated by using the CHEMEQ·BAS software and shown in Figure 11 (This is identical to Figure 1 and is reproduced here for convenience). Since the WGS reaction is reversible and slightly exothermic in nature, the equilibrium constant $\left(\mathrm{K}_{\mathrm{e}}\right)$ of the WGS reaction decreases with increasing temperature. From Equation 25, the value of equilibrium conversion $\left(\mathrm{X}_{\mathrm{e}}\right)$ also decreases with increasing temperature. On a thermodynamic equilibrium basis, it is desirable to perform the WGS reaction at low temperatures. However, the reaction kinetics are very slow at low temperatures. On the other hand, at high temperatures, the reaction kinetics are fast but the equilibrium constant and the equilibrium conversion are low. Consequently, the optimum conversion is obtainable at optimum temperature where the reaction kinetics and equilibrium are favorable.

\subsection{Effect of the $\mathrm{H}_{2} \mathrm{O} / \mathrm{CO}$ ratio on equilibrium $\mathrm{CO}$ conversion $\left(\mathrm{X}_{\mathrm{e}}\right)$}

The effect of inlet $\mathrm{H}_{2} \mathrm{O} / \mathrm{CO}$ ratio on equilibrium conversion $\left(\mathrm{X}_{\mathrm{e}}\right)$ is shown in

Figure 12. The calculation procedure for equilibrium $\mathrm{CO}$ conversions for various 


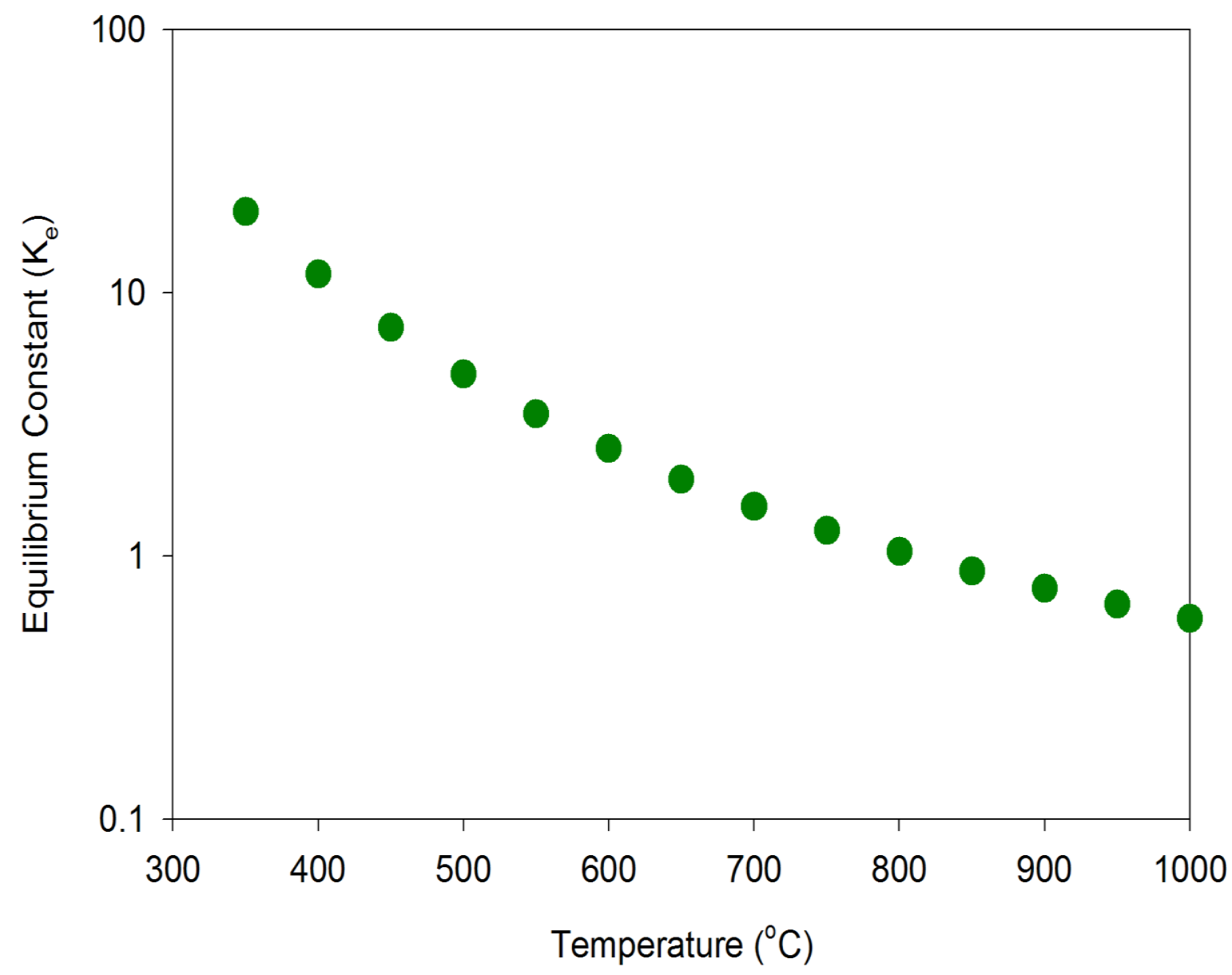

Figure 11. Effect of temperature on equilibrium constant $\left(\mathrm{K}_{\mathrm{e}}\right)$ of WGS reaction. $\mathrm{H}_{2} \mathrm{O} / \mathrm{CO}$ ratios is given in Appendix E. From Figure 12, it can be observed that the equilibrium conversion of $\mathrm{CO}$, and hence the $\mathrm{H}_{2}$ yield, decreases with increase in temperature. This is consistent with Figure 11. For instance, a CO conversion of 82 $\%$ obtained at $350{ }^{\circ} \mathrm{C}$ is reduced to $69 \%$ at $450{ }^{\circ} \mathrm{C}$ for same $\mathrm{H}_{2} \mathrm{O} / \mathrm{CO}$ ratio $\left(\mathrm{H}_{2} \mathrm{O} / \mathrm{CO}\right.$ = 1). The equilibrium $\mathrm{CO}$ conversion increases with the increase in the $\mathrm{H}_{2} \mathrm{O} / \mathrm{CO}$ ratio at the same temperature. Increasing the amount of $\mathrm{H}_{2} \mathrm{O}$ increases the forward rate of reaction. For example, the conversion of $\mathrm{CO}$ is $73 \%$ at $450{ }^{\circ} \mathrm{C}$ for a $\mathrm{H}_{2} \mathrm{O} / \mathrm{CO}$ ratio of 1 while it is $90 \%$ for a $\mathrm{H}_{2} \mathrm{O} / \mathrm{CO}$ ratio of $2: 1$. However, the use of very high steam- 
to-CO ratios (greater than $5: 1$ ) has little effect on $\mathrm{CO}$ conversion. Also, the production of large amount of steam from water requires more energy. Therefore, a $\mathrm{H}_{2} \mathrm{O} / \mathrm{CO}$ ratio of 2 to 3 is reasonable for the WGS reaction.

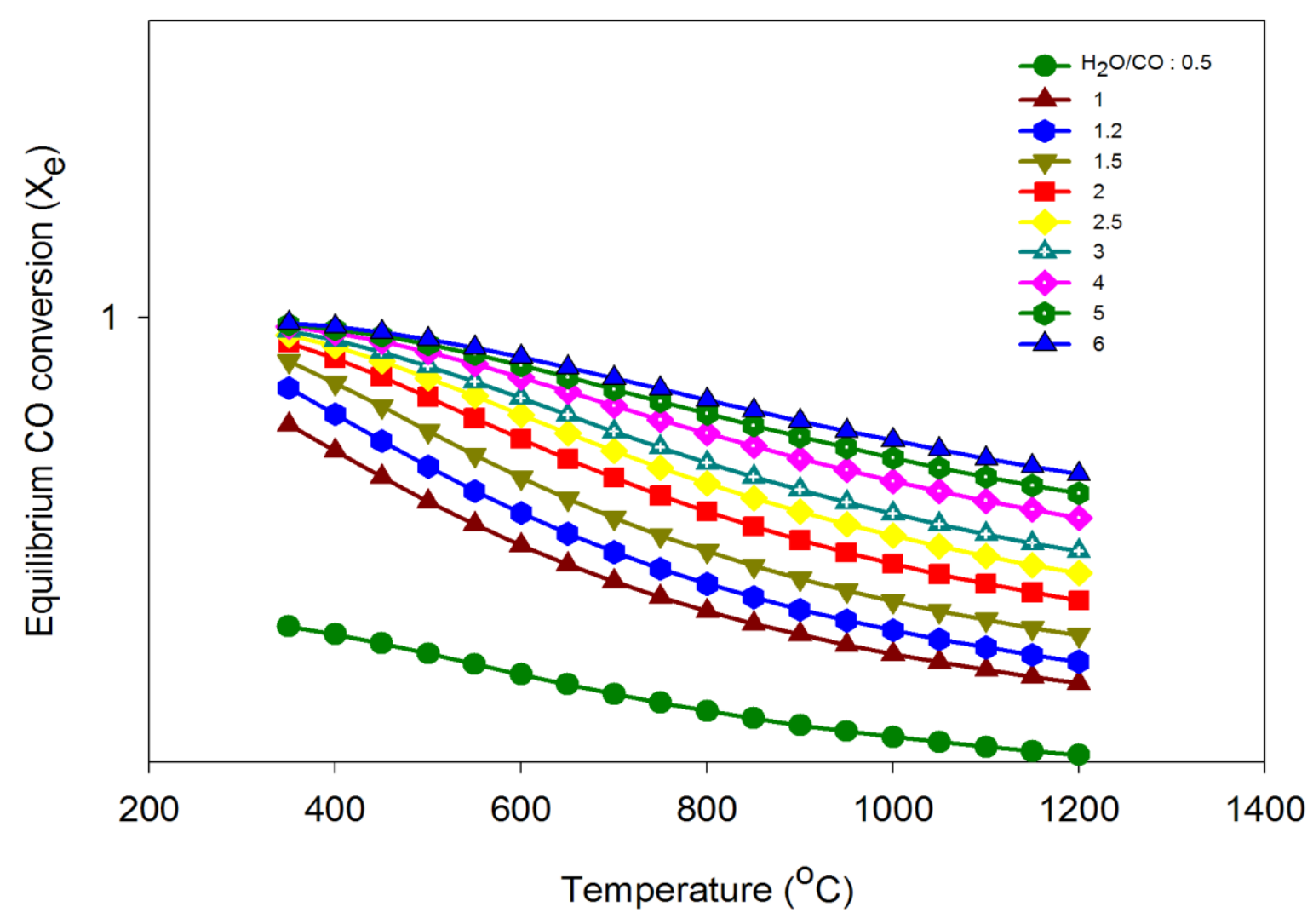

Figure 12. Effect of inlet $\mathrm{H}_{2} \mathrm{O} / \mathrm{CO}$ ratio on $\mathrm{CO}$ conversion at thermodynamic equilibrium

\subsection{Effect of sorbent presence on equilibrium CO conversion $\left(X_{e}\right)$}

The effect of different levels of $\mathrm{CO}_{2}$ capture on the equilibrium $\mathrm{CO}$ conversion of WGS reaction as a function of $\mathrm{H}_{2} \mathrm{O} / \mathrm{CO}$ ratios at a temperature of $500{ }^{\circ} \mathrm{C}$ is shown in Figure 13. The calculation procedure for the effect of the sorbent on equilibrium 
$\mathrm{CO}$ conversions is given in Appendix $\mathrm{F}$. The removal of $\mathrm{CO}_{2}$ from the reaction zone decreases the rate of the reverse reaction. This is equivalent to decreasing the value of $\mathrm{H}_{2} \mathrm{O} / \mathrm{CO}$ ratio at the inlet. For example, a CO conversion of $90 \%$ is possible at 500 ${ }^{\circ} \mathrm{C}$ with a $\mathrm{H}_{2} \mathrm{O} / \mathrm{CO}$ ratio of 2.5 while approximately the same equilibrium conversion ( $\mathrm{X}_{\mathrm{e}}$ ) is obtainable at $500{ }^{\circ} \mathrm{C}$ with a $\mathrm{H}_{2} \mathrm{O} / \mathrm{CO}$ ratio of 1 in the presence of a sorbent that can capture $75 \%$ of the $\mathrm{CO}_{2}$ product. This is in accordance with Le Chatelier's principle, by which the removal of one product from the reaction zone will drive an equilibrium-limited reaction in the forward direction. Therefore, the steam usage may be greatly reduced,

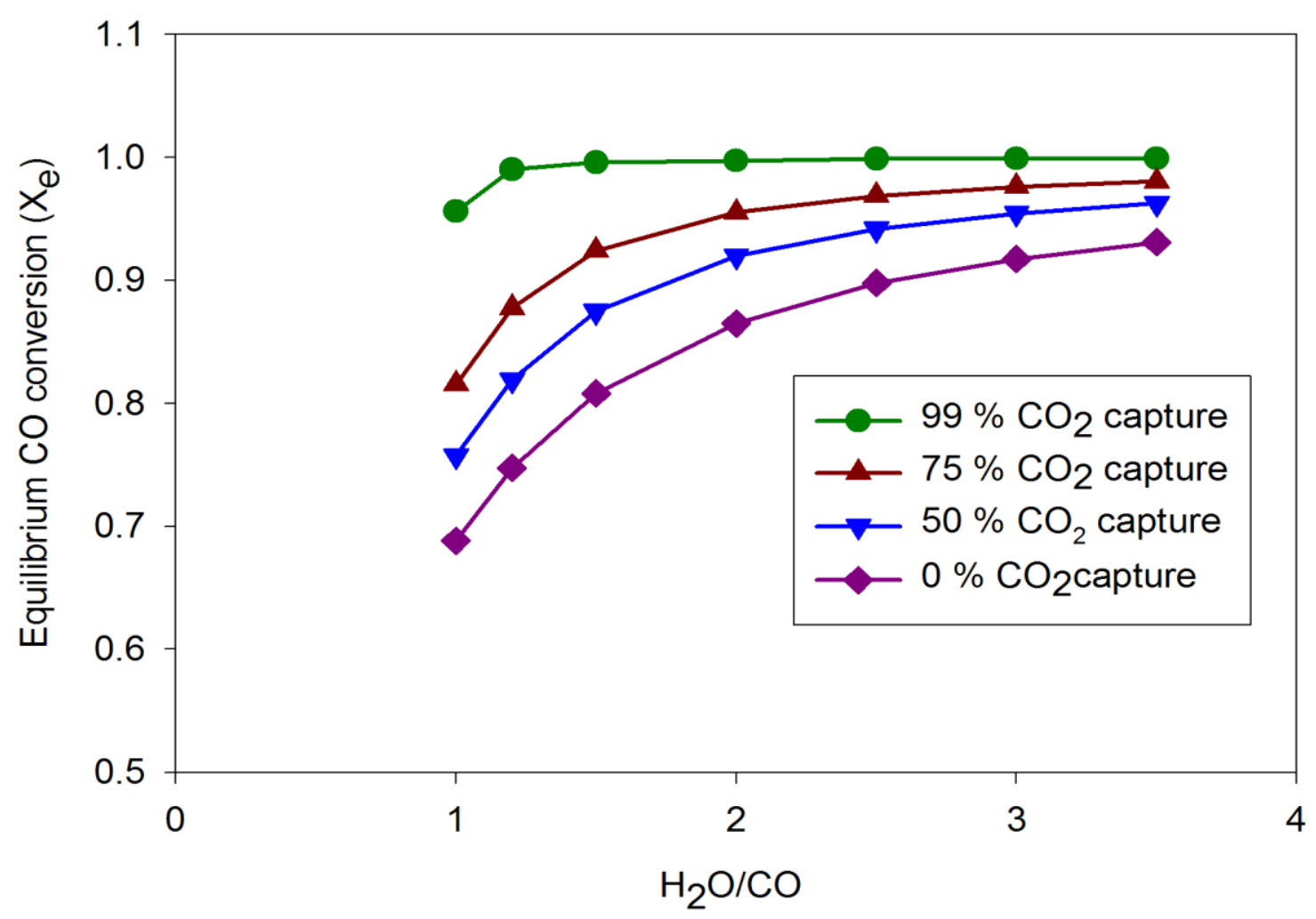

Figure 13. Effect of $\mathrm{CO}_{2}$ removal on equilibrium $\mathrm{CO}$ conversion of WGS reaction at $500{ }^{\circ} \mathrm{C}$ for various $\mathrm{H}_{2} \mathrm{O} / \mathrm{CO}$ ratios. 
resulting in less operating cost. The higher equilibrium conversion of $\mathrm{CO}$ to $\mathrm{H}_{2}$, compared to that obtained in conventional WGS reactions without $\mathrm{CO}_{2}$ removal, allows a higher operating temperature of the reactor, resulting in faster kinetics.

\subsection{Activity of the blank reactor}

Blank tests were conducted to study the activity of WGS reaction in the absence of the catalyst. In this case, the reactor was totally filled with quartz chips of size $1 / 16$ " without catalyst. The details of the reactor loading are given in Section 3.11. Experiments were carried out in the temperature range of $450-600{ }^{\circ} \mathrm{C}$ and a pressure of $1 \mathrm{~atm}$. The stainless-steel reactor was pretreated using a gas mixture of $\mathrm{H}_{2} / \operatorname{Ar}(10 / 90 \%)$ with a total flow rate of $170 \mathrm{sccm}$ at $300^{\circ} \mathrm{C}$ for 3 hours. The pretreatment was performed at atmospheric pressure and was similar to that for catalyst testing. Subsequently, the temperature was increased with a ramp rate of 5 ${ }^{\circ} \mathrm{C} /$ min to the reaction temperature. The system was purged with $100 \%$ Ar with a flow rate of $200 \mathrm{sccm}$ for 2 hours to remove any traces of hydrogen in the reactor. Then the feed gas comprised of $\mathrm{CO}, \mathrm{He}, \mathrm{Ar}$, and $\mathrm{H}_{2} \mathrm{O}$ was introduced into the reactor. The feed ratio used for each experiment was $\mathrm{CO}: \mathrm{H}_{2} \mathrm{O}: \mathrm{Ar}: \mathrm{He}=$ 1:2:1.44:0.0055 with a total flow rate of $200 \mathrm{sccm}$.

The effect of temperature on the activity of the stainless-steel reactor for WGS reaction in the range of $450-600{ }^{\circ} \mathrm{C}$ is shown in Figures $14 \& 15$. There is negligible activity of the WGS reaction between $450-500{ }^{\circ} \mathrm{C}$ and almost no products

are observed. Between $550-600^{\circ} \mathrm{C}$, carbon monoxide conversion and hydrogen flow rates are measurable but small, and of the order of GC measurement error. 


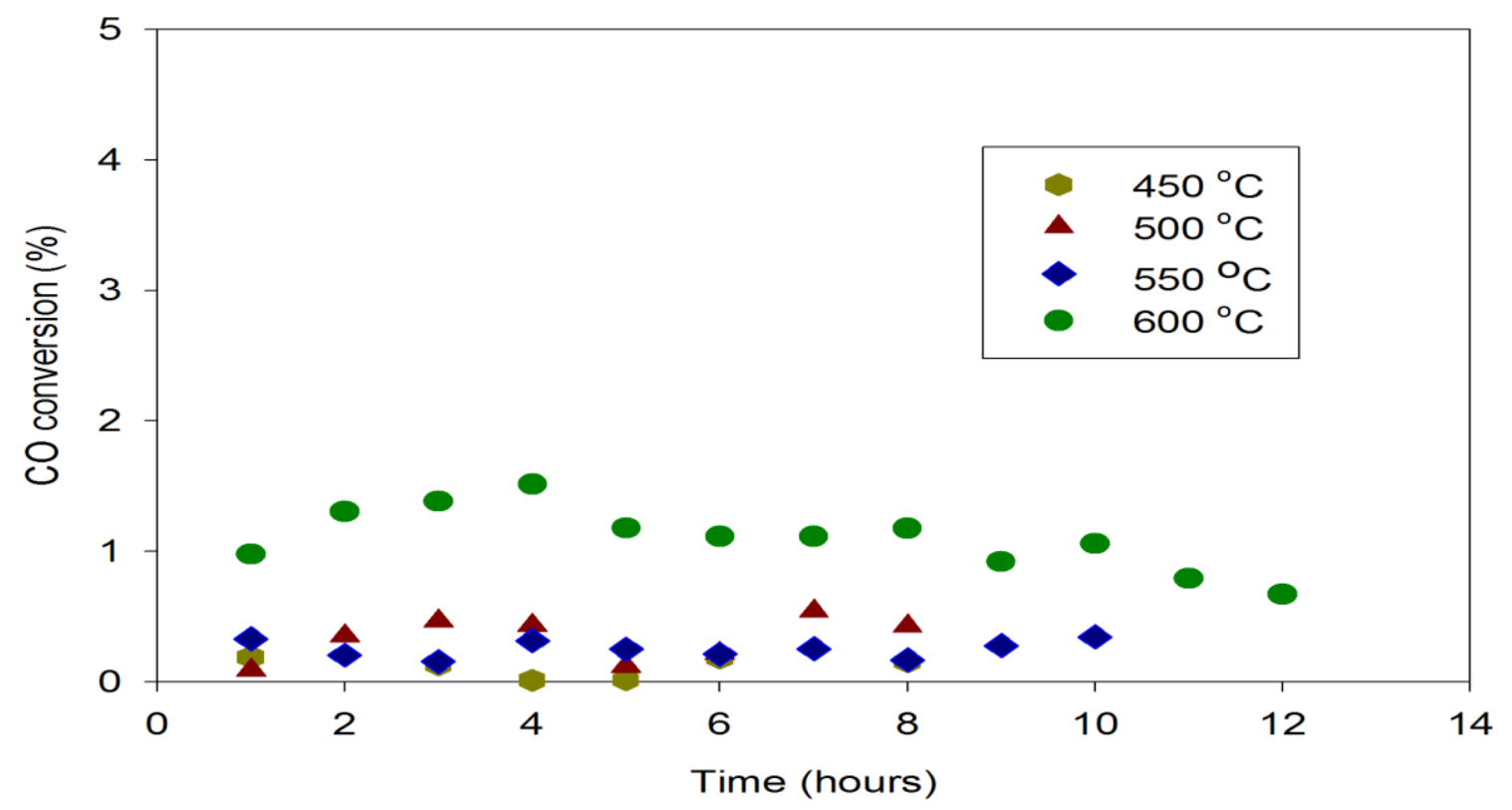

Figure 14. Effect of reaction temperatures on the activity of the blank reactor for WGS reaction (Total pressure: $1 \mathrm{~atm}, \mathrm{H}_{2} \mathrm{O} / \mathrm{CO}: 2,22 \% \mathrm{CO}$, total flow: $200 \mathrm{sccm}$ ).

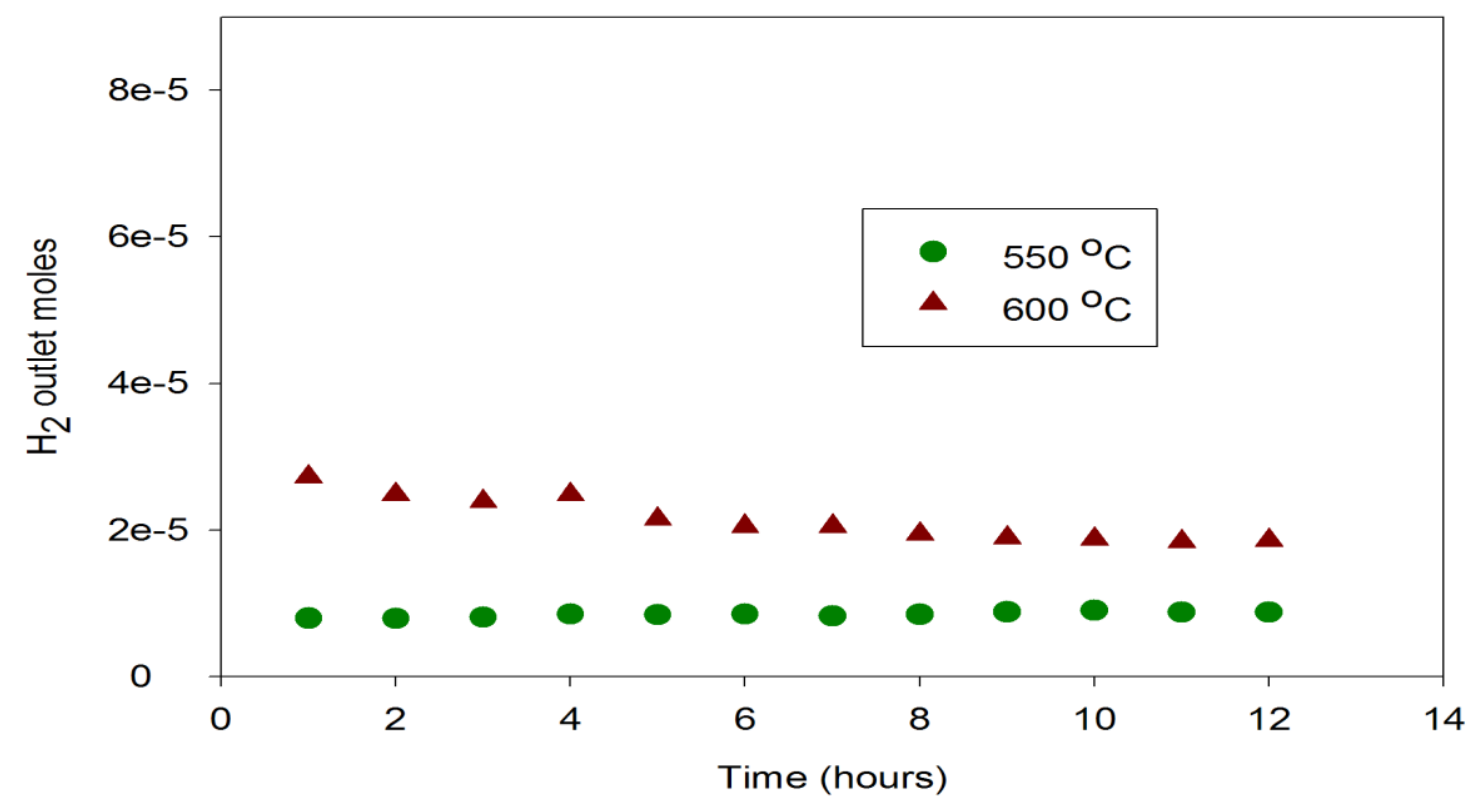

Figure 15. Formation of $\mathrm{H}_{2}$ gas in the blank reactor during the WGS reaction at different temperatures $\left(550-600{ }^{\circ} \mathrm{C}\right.$ ) (Total pressure: $1 \mathrm{~atm}, \mathrm{H}_{2} \mathrm{O} / \mathrm{CO}: 2,22 \% \mathrm{CO}$, total flow: $200 \mathrm{sccm})$. 


\subsection{Thermodynamics and kinetics of the WGS reaction}

Experiments were carried out to study the activity of the HTS catalyst $\left(\mathrm{Fe}_{2} \mathrm{O}_{3} / \mathrm{Cr}_{2} \mathrm{O}_{3} / \mathrm{CuO}\right)$ for the WGS reaction in the temperature range of $350-600{ }^{\circ} \mathrm{C}$ at 1 atm pressure. The experiments were performed with a reaction gas mixture comprising of $\mathrm{CO}, \mathrm{He}, \mathrm{CO}_{2}, \mathrm{Ar}$, and $\mathrm{H}_{2} \mathrm{O}$. The total feed ratio used was $\mathrm{CO}: \mathrm{H}_{2} \mathrm{O}$ : $\mathrm{Ar}$ : $\mathrm{He}=1: 2: 1.44: 0.0055$, with a total feed rate of $200 \mathrm{sccm}$. Typically, $0.2 \mathrm{~g}$ of HTS catalyst of 20-40 mesh was loaded for each experiment.

The catalytic activity of the HTS catalyst (carbon monoxide conversion) was obtained from the difference between inlet and outlet compositions. The activity increases monotonically as the temperature increases which is evident from Figure 16. The CO conversion increases from $21 \%$ at $350{ }^{\circ} \mathrm{C}$ to $75 \%$ at $500{ }^{\circ} \mathrm{C}$. Beyond $500{ }^{\circ} \mathrm{C}$, the conversion does not change much. This is due to the thermodynamic limitations imposed on the WGS reaction. These data were further analyzed to determine whether the system was operated within the range of thermodynamic equilibrium as determined in Figure 12.

The comparison of experimental and equilibrium $\mathrm{CO}$ conversions is shown in Figure 17. From the figure, it can be seen that the reaction system is operated in the region below the thermodynamic equilibrium. The equilibrium conversion $\left(X_{e}\right)$ decreases continuously with increasing temperature. In contrast, the experimental conversion $(X)$ increases with respect to temperature studied within the range of $350-600{ }^{\circ} \mathrm{C}$. Thus at $600{ }^{\circ} \mathrm{C}$, the experimental conversion $(\mathrm{X})$ increases to 0.765 while the equilibrium conversion $\left(X_{e}\right)$ decreases to 0.795 . It is clearly evident from 


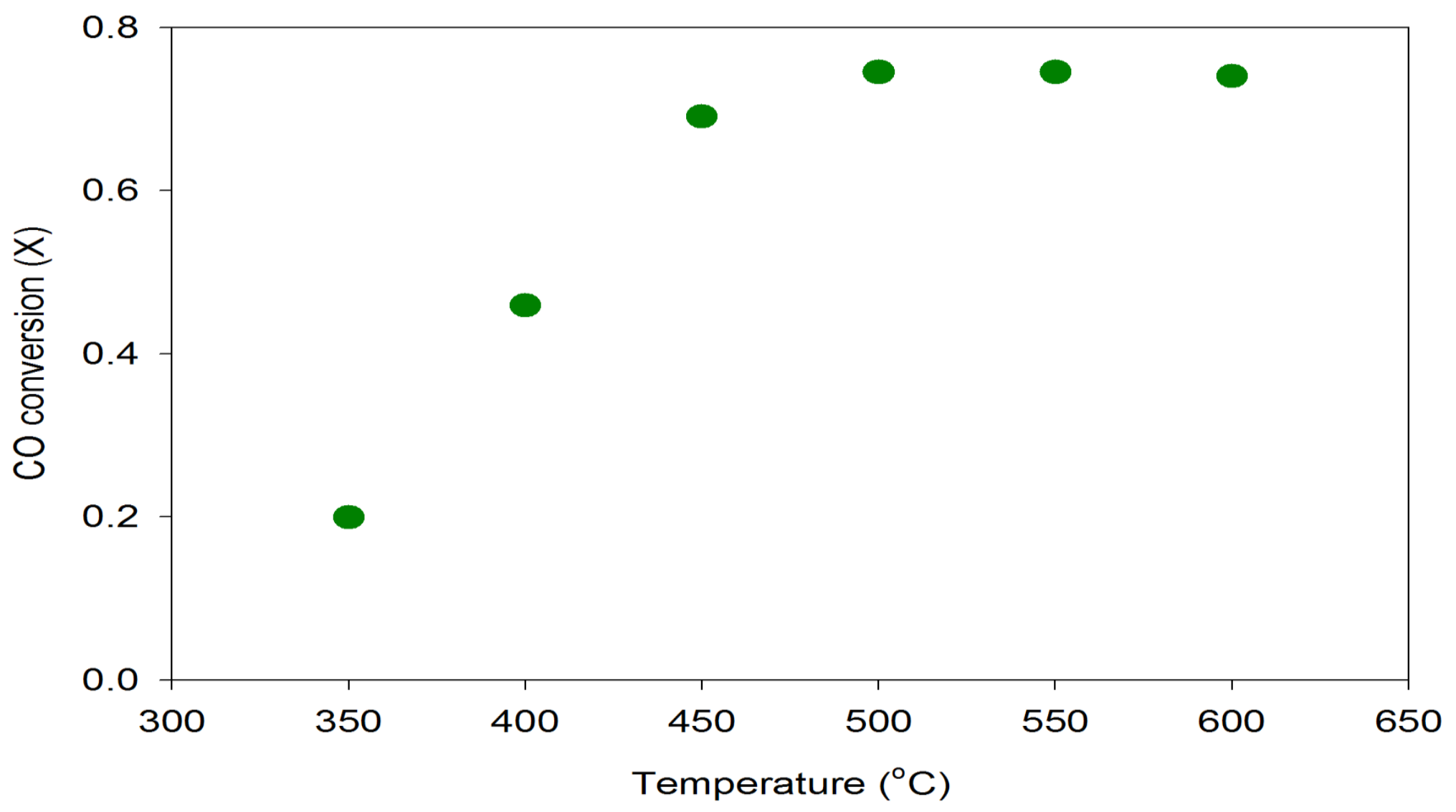

Figure 16. Effect of reaction temperature on the CO conversion $(0.25 \mathrm{~g}$ of HTS catalyst, P: $1 \mathrm{~atm}, 22.2 \% \mathrm{CO}$, $\mathrm{H}_{2} \mathrm{O} / \mathrm{CO}: 2$, total flow: $200 \mathrm{sccm}$ ). 
Figure 17 that the system moves closer to equilibrium as temperature increases from $350^{\circ} \mathrm{C}$ to $600^{\circ} \mathrm{C}$.

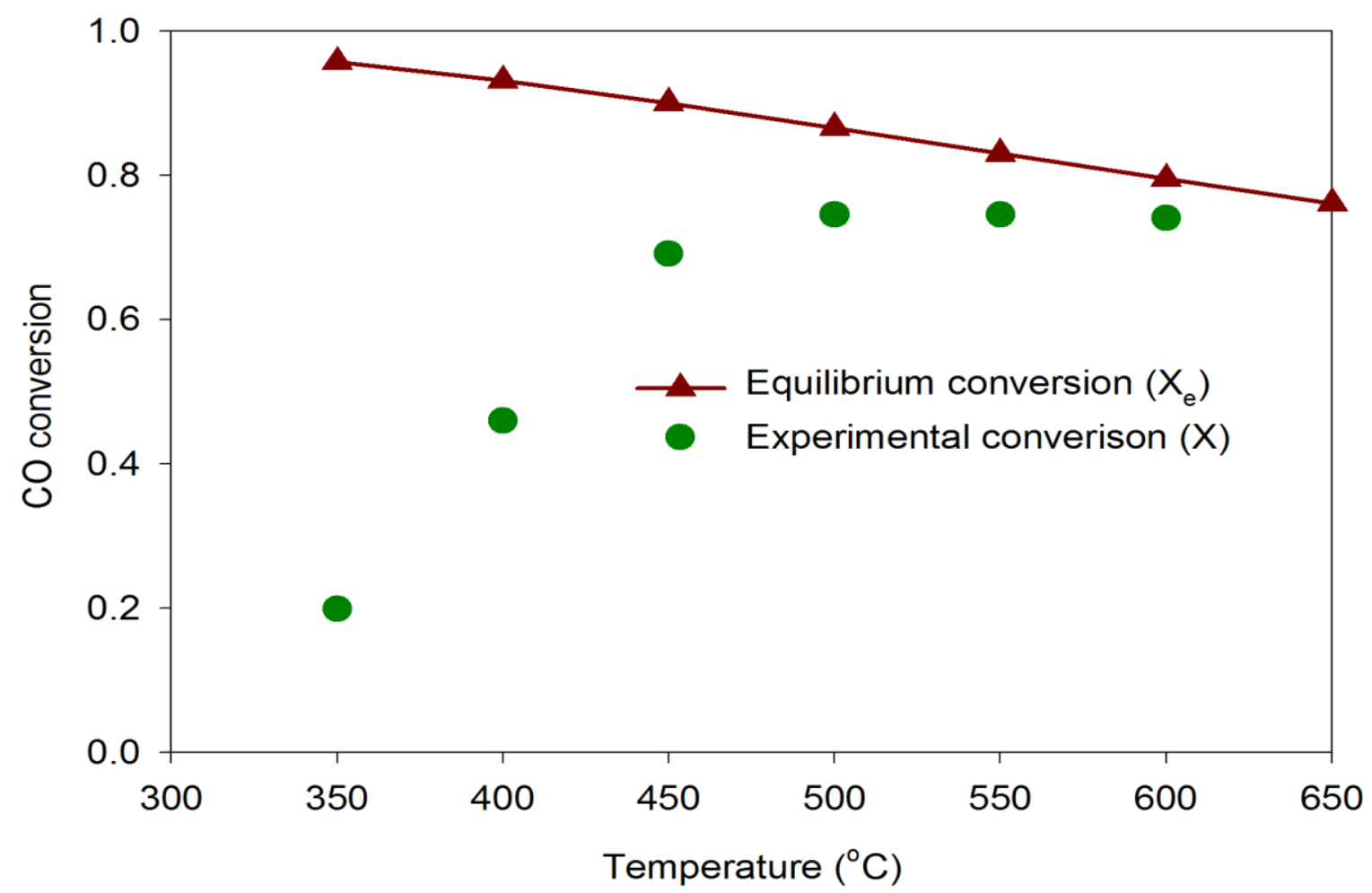

Figure 17. Comparison of equilibrium and experimental $\mathrm{CO}$ conversions for WGS reaction in the temperature range of $350-600{ }^{\circ} \mathrm{C}(0.25 \mathrm{~g}$ of HTS catalyst, $22.2 \% \mathrm{CO}$, $\mathrm{P}: 1 \mathrm{~atm}, \mathrm{H}_{2} \mathrm{O} / \mathrm{CO}: 2$, total flow: $200 \mathrm{sccm}$ ).

\subsection{Effect of the reaction temperature on $\mathrm{CO}$ conversion for various}

\section{$\mathrm{H}_{2} \mathrm{O} / \mathrm{CO}$ ratios}

The effect of reaction temperature on $\mathrm{CO}$ conversions for two different $\mathrm{H}_{2} \mathrm{O} / \mathrm{CO}$ ratios is given in Figure 18. The conversion increases with increase in the $\mathrm{H}_{2} \mathrm{O} / \mathrm{CO}$ ratio. For example, the conversion of $\mathrm{CO}$ is $58 \%$ at $500{ }^{\circ} \mathrm{C}$ for a $\mathrm{H}_{2} \mathrm{O} / \mathrm{CO}$ ratio of 1 , while it is $75 \%$ for $\mathrm{H}_{2} \mathrm{O} / \mathrm{CO}$ ratio of 2 . The increased concentration of reactant $\mathrm{H}_{2} \mathrm{O}$ increases the rate of the forward reaction. From Figure 18, it is also 
observed that, as the temperature increases, the $\mathrm{CO}$ conversions increase for both $\mathrm{H}_{2} \mathrm{O} / \mathrm{CO}$ ratios. However, the effect of $\mathrm{H}_{2} \mathrm{O} / \mathrm{CO}$ ratio is small at low temperatures, and increases with increase in temperature. Also, the comparison of equilibrium and experimental $\mathrm{CO}$ conversion for two different $\mathrm{H}_{2} \mathrm{O}$ / $\mathrm{CO}$ ratios at various temperatures is given in Figure 18 .

\subsection{Kinetics of WGS reaction}

Assuming both sides of the WGS reaction to be of first order in each component, the forward and reverse kinetic parameters, $\mathrm{k}_{\mathrm{f}}$ and $\mathrm{k}_{\mathrm{r}}$ were calculated. The activation energy $\left(E_{a}\right)$ and pre-exponential factor $\left(k_{0}\right)$ of the WGS reaction were calculated using the Arrhenius equation. The calculation procedure is given in Appendix H.

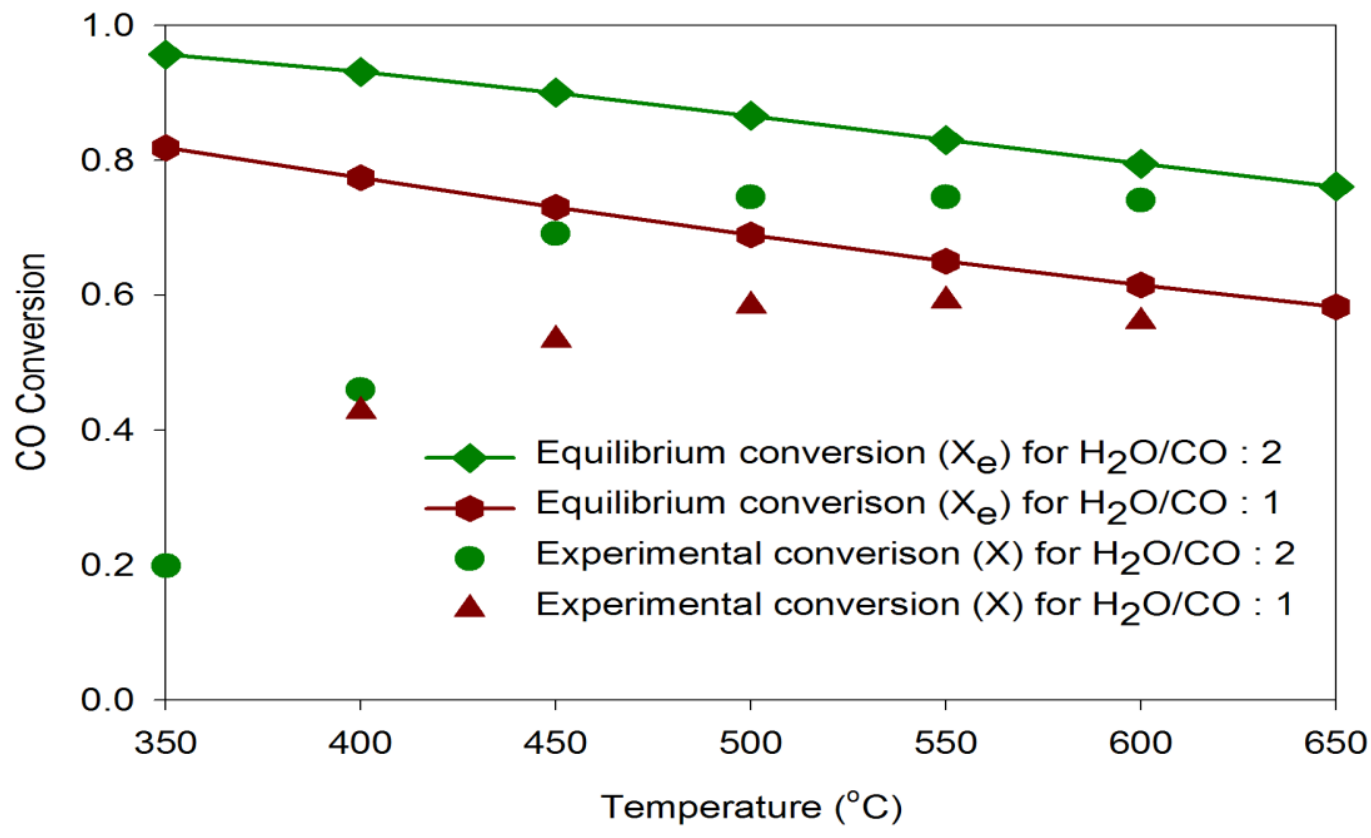

Figure 18. Effect of $\mathrm{H}_{2} \mathrm{O} / \mathrm{CO}$ ratio on $\mathrm{CO}$ conversion for various temperatures $(0.25 \mathrm{~g}$ of HTS catalyst, $22.2 \% \mathrm{CO}, \mathrm{H}_{2} \mathrm{O} / \mathrm{CO}: 1,2$, P: 1 atm, total flow: $200 \mathrm{sccm}$ ). 
The rate equation for the WGS reaction is given below:

$-r=k_{f}[\mathrm{PCO}]\left[\mathrm{PH}_{2} \mathrm{O}\right]-\mathrm{k}_{\mathrm{r}}\left[\mathrm{P}_{2}\right]\left[\mathrm{PCO}_{2}\right]$

where,

$-r=$ rate of consumption of $\mathrm{CO}, \mathrm{H}_{2} \mathrm{O}$

$\mathrm{PCO}, \mathrm{P}_{2} \mathrm{O}, \mathrm{PCO}_{2}$, and $\mathrm{PH}_{2}$, are the partial pressures of $\mathrm{CO}, \mathrm{H}_{2} \mathrm{O}, \mathrm{CO}_{2}$, and $\mathrm{H}_{2}$ The parameters $k_{f}$ and $k_{r}$ are related to the equilibrium constant $\left(K_{e}\right)$ by:

$$
K_{e}=\frac{k_{f}}{k_{r}}
$$

The rate constants $\mathrm{k}_{\mathrm{f}}$ and $\mathrm{k}_{\mathrm{r}}$ are related to the absolute temperature $\mathrm{T}$ by:

$\mathrm{k}=\mathrm{k}_{0} \exp \left(\mathrm{E}_{\mathrm{a}} / \mathrm{RT}\right)$

where,

$\mathrm{k}_{0}=$ pre-exponential factor $\left(\mathrm{mol} / \mathrm{min} / \mathrm{g}\right.$ catalyst $/(\mathrm{atm})^{2}$

$E_{a}=$ activation energy $(\mathrm{kJ} / / \mathrm{mol})$

$R=$ universal gas constant $(\mathrm{J} / \mathrm{mol} . \mathrm{K})$

The forward and reverse reaction constants, $k_{f}$ and $k_{r}$ of the WGS reaction over HTS catalyst are calculated and summarized in Table 12. The calculation procedure is given in Appendix $\mathrm{H}$. From the table, as the temperature increases, the rate constants, $k_{f}$ and $k_{r}$ increase. The activation energy $\left(E_{a}\right)$ and pre-exponential factor from the data in Table 12 are obtained from Figure 19 and given in Table 13.

Also shown in Table 13 are the corresponding values from the literature. The values obtained in the present work fall in the range of values obtained in the literature. 
Table 12. Forward $\left(\mathrm{k}_{\mathrm{f}}\right)$ and reverse $\left(\mathrm{k}_{\mathrm{r}}\right)$ reaction constants of WGS reaction at different temperatures

\begin{tabular}{|c|c|c|c|}
\hline$T(K)$ & $K_{e}$ & $k_{f}\left(\mathrm{~mol} / \mathrm{sec} / \mathrm{g}\right.$ catalyst $/ \mathrm{atm}^{2}$ & $\mathrm{K}_{\mathrm{r}}\left(\mathrm{mol} / \mathrm{sec} / \mathrm{g}\right.$ catalyst $/(\mathrm{am})^{2}$ \\
\hline 623 & 20.44 & $4.48 \times 10^{-4}$ & $2.19 \times 10^{-5}$ \\
\hline 673 & 11.73 & $1.92 \times 10^{-3}$ & $1.64 \times 10^{-4}$ \\
\hline 698 & 9.17 & $3.82 \times 10^{-3}$ & $4.17 \times 10^{-4}$ \\
\hline 723 & 7.31 & $7.52 \times 10^{-3}$ & $1.02 \times 10^{-3}$ \\
\hline 773 & 4.87 & $1.40 \times 10^{-2}$ & $2.87 \times 10^{-3}$ \\
\hline 823 & 3.43 & $1.60 \times 10^{-2}$ & $4.68 \times 10^{-3}$ \\
\hline
\end{tabular}




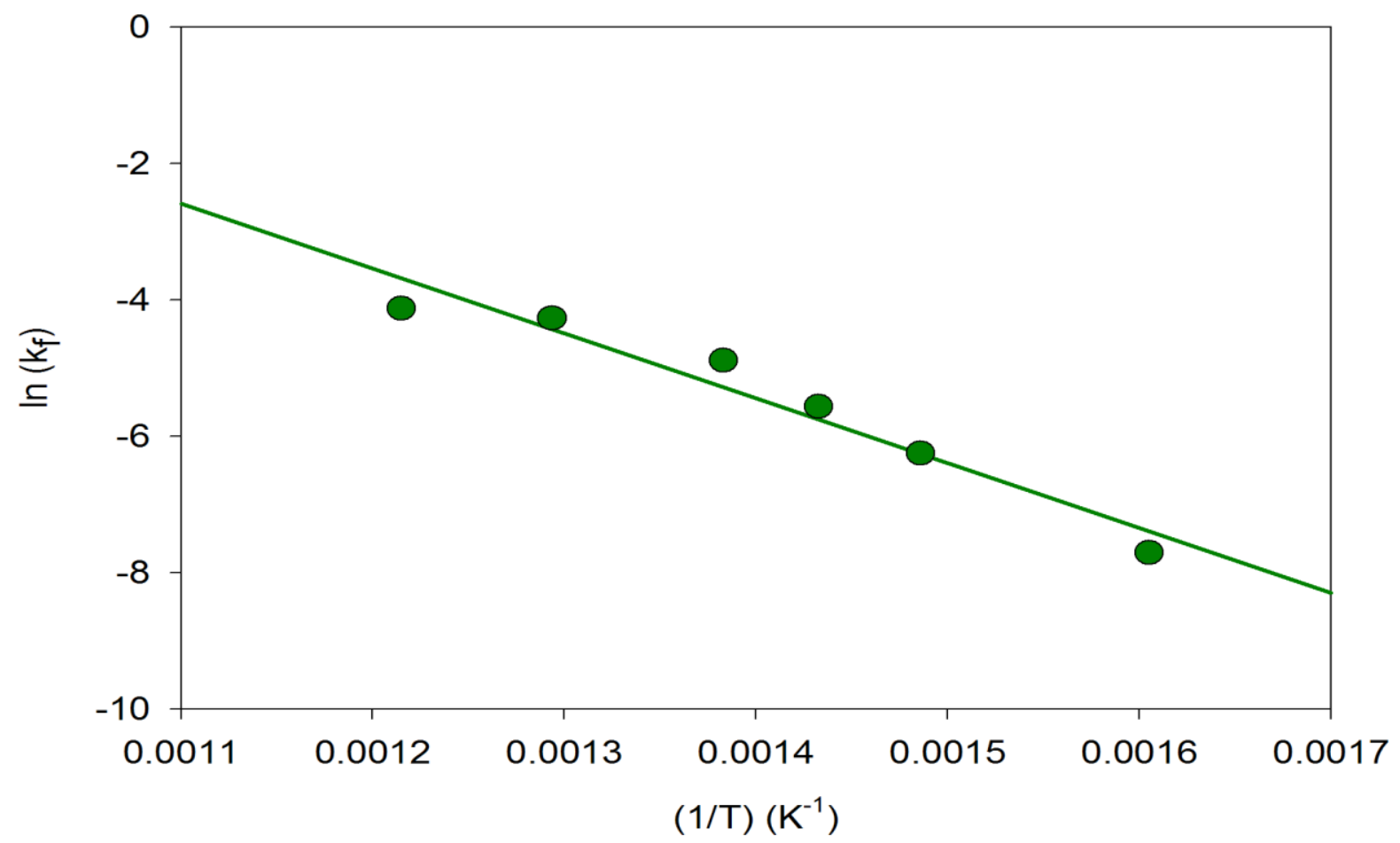

Figure 19. Arrhenius plot for WGS reaction (T: $350-550^{\circ} \mathrm{C}$, catalyst weight: $0.2 \mathrm{~g}, 22$ $\left.\% \mathrm{CO}, \mathrm{H}_{2} \mathrm{O} / \mathrm{CO}: 2, \mathrm{P}: 1 \mathrm{~atm}\right)$.

Table 13. Arrhenius parameters for the WGS reaction over various HTS catalysts

\begin{tabular}{|c|c|c|c|}
\hline Catalyst name & $\mathrm{E}_{\mathrm{a}}(\mathrm{kJ} / \mathrm{mol})$ & Ink & Reference \\
\hline $\begin{array}{c}\mathrm{Fe}_{2} \mathrm{O}_{3} / \mathrm{Cr}_{2} \mathrm{O}_{3} / \mathrm{CuO} \\
(88 \% / 8.1 \% / 2.5 \%)\end{array}$ & 79.01 & 7.8 & current work \\
\hline $\begin{array}{c}\mathrm{Fe}_{2} \mathrm{O}_{3} / \mathrm{Cr}_{2} \mathrm{O}_{3} / \mathrm{CuO} \\
(80-90 \% / 8-13 \% / 1-2 \%)\end{array}$ & 111 & 6.55 & 58 \\
\hline $\mathrm{Fe}_{2} \mathrm{O}_{3} / \mathrm{Cr}_{2} \mathrm{O}_{3} / \mathrm{CuO}$ & 85 & $5.5 \pm 0.1$ & 60 \\
\hline $\mathrm{Fe}_{2} \mathrm{O}_{3} / \mathrm{Cr}_{2} \mathrm{O}_{3}$ & $118 \pm 1$ & $10.1 \pm 0.2$ & 59 \\
\hline
\end{tabular}




\subsection{Study of sorbent activity for WGS reaction without catalyst}

Experiments were conducted to study the catalytic activity of the sorbents $\mathrm{CaO}$ and $\mathrm{CaO} / \mathrm{Ca}_{12} \mathrm{Al}_{14} \mathrm{O}_{33}(75 / 25$ wt \% and $50 / 50$ wt \%) towards WGS and $\mathrm{CO}$ conversion without any HTS catalyst at $500^{\circ} \mathrm{C}$. The CO conversions of WGS reaction over various sorbents are given in Figure 20. The product profiles are given in Figure 21.

The $\mathrm{CaO}$ sorbent does not show any catalytic activity. The $\mathrm{CaO} / \mathrm{Ca}_{12} \mathrm{Al}_{14} \mathrm{O}_{33}$, materials, both $75 / 25$ and $50 / 50$, show minute activity towards the WGS reaction at $500{ }^{\circ} \mathrm{C}$. The $\mathrm{CO}$ conversion is around $2-3 \%$ in this range.

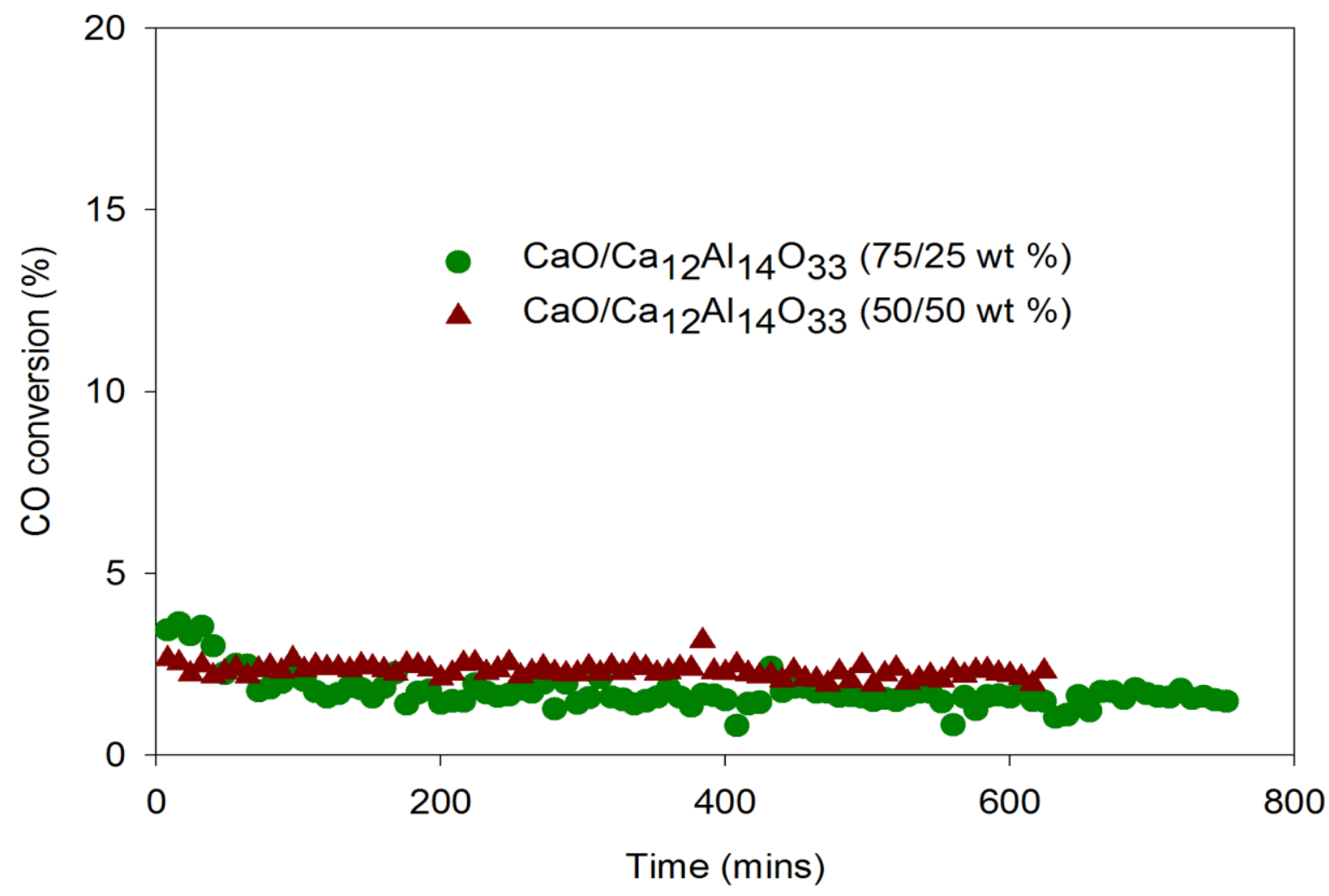

Figure 20. Catalytic activity of sorbents towards WGS reaction $\left(\mathrm{T}: 500{ }^{\circ} \mathrm{C}\right.$, sorbent: $\mathrm{CaO} / \mathrm{Ca}_{12} \mathrm{Al}_{14} \mathrm{O}_{33}(75 / 25$ and 50/50 wt \%), sorbent weight: $2.5 \mathrm{~g}$, Pressure: $1 \mathrm{~atm})$. 


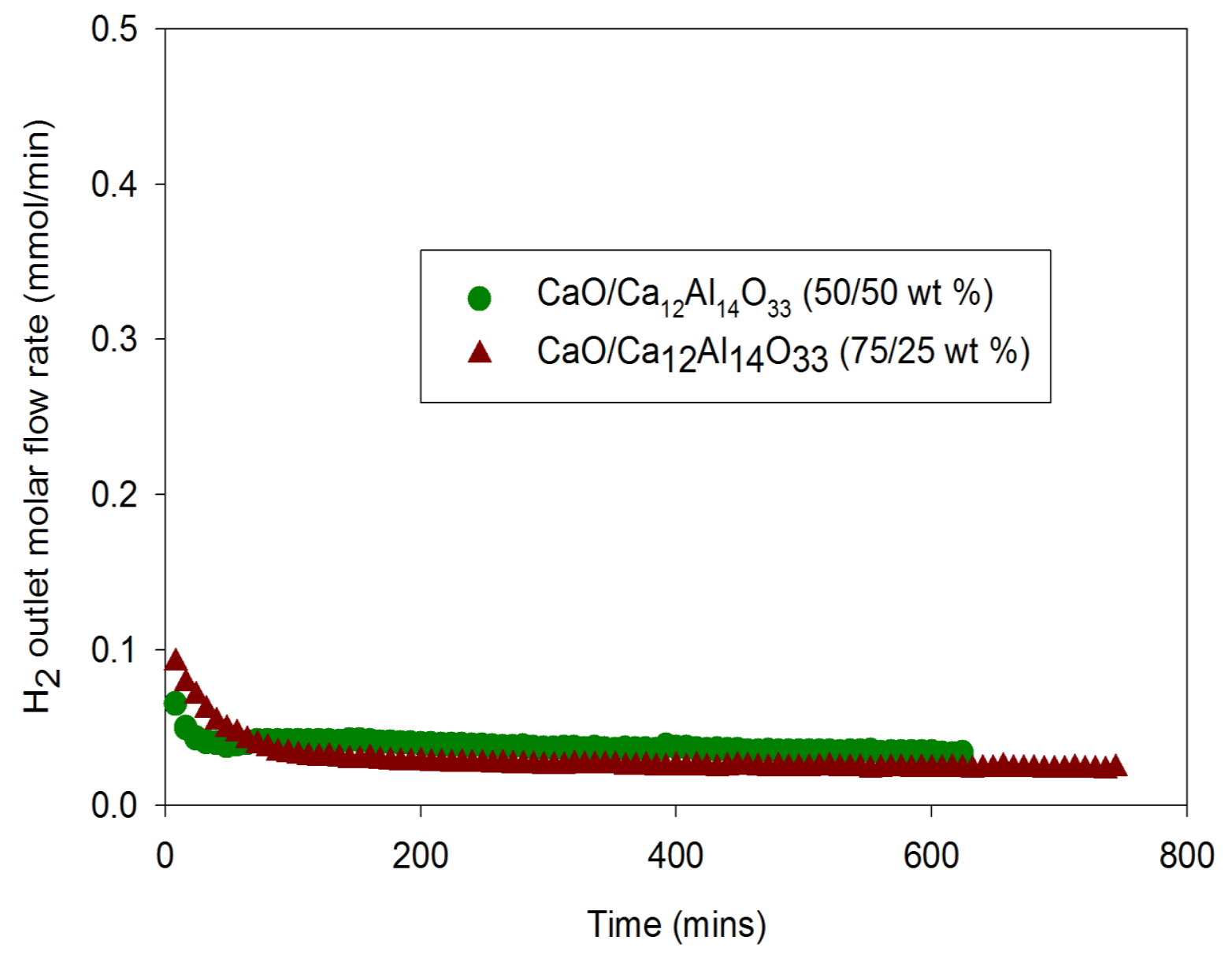

Figure 21. Formation of hydrogen during WGS reaction over sorbents $\left(\mathrm{T}: 500{ }^{\circ} \mathrm{C}\right.$, sorbents: $\mathrm{CaO} / \mathrm{Ca}_{12} \mathrm{Al}_{14} \mathrm{O}_{33} 75 / 25$ wt $\%$ and $\mathrm{CaO} / \mathrm{Ca}_{12} \mathrm{Al}_{14} \mathrm{O}_{33} 50 / 50$ wt \%, sorbent weight: $2.5 \mathrm{~g}$, Pressure: $1 \mathrm{~atm})$.

\subsection{Combined WGS and carbonation reactions with HTS catalyst- sorbent system}

The combined WGS and carbonation reactions were conducted in two different modes. In the first case, the catalyst and sorbent were mixed uniformly and kept in the reactor as single bed. This concept is also called sorption-enhanced WGS reaction. In the second case, the HTS catalyst and sorbent were kept as separate beds with separation by quartz chips. 


\subsubsection{HTS catalyst and sorbent mixture}

The sorption-enhanced WGS reaction was carried out at $500{ }^{\circ} \mathrm{C}$ with an operating pressure of $1 \mathrm{~atm}$. The following reactions take place during the sorptionenhanced WGS reaction:

$$
\begin{aligned}
& \mathrm{CO}(\mathrm{g})+\mathrm{H}_{2} \mathrm{O}(\mathrm{g}) \Leftrightarrow \mathrm{H}_{2}(\mathrm{~g})+\mathrm{CO}_{2}(\mathrm{~g}) \\
& \mathrm{CaO}(\mathrm{s})+\mathrm{CO}_{2}(\mathrm{~g}) \Leftrightarrow \mathrm{CaCO}_{3}(\mathrm{~s})
\end{aligned}
$$

Typically $0.2 \mathrm{~g}$ of HTS catalyst and $2.5 \mathrm{~g}$ of sorbent $(\mathrm{CaO}$ or $\left.\mathrm{CaO} / \mathrm{Ca}_{12} \mathrm{Al}_{14} \mathrm{O}_{33}\right)$ were mixed thoroughly and diluted with fine quartz chips with a ratio of 1:4. Then the catalyst-sorbent system was loaded into the reactor. Subsequently, the HTS catalyst-sorbent system was reduced at $300^{\circ} \mathrm{C}$ using $\mathrm{H}_{2} / \mathrm{Ar}$ (10/90 \%) with a total flow of $170 \mathrm{sccm}$ for 2 hours. Then, the system was purged with argon for 2 hours to remove any trace amount of hydrogen on the surface of the HTS catalyst. Finally, the reaction gas mixture with a composition of CO-17.54\%, $\mathrm{He}-0.92 \%, \mathrm{H}_{2} \mathrm{O}-34.67 \%$, and $\mathrm{Ar}-46.87 \%$ was allowed to flow through the reactorsystem.

The reaction was conducted for 3 hours. The GC continuously monitored the flow of product gases from reactor outlet with an interval of 8 min. Since $\mathrm{CO}_{2}$ has retention time of 6.3 minutes, product analysis was carried out using gas chromatograph with a time interval of 8 minutes. For instance, if sample is injected at $8^{\text {th }}$ min, the product data will be obtained at $8^{\text {th }}, 16^{\text {th }}, 24^{\text {th }}, 32^{\text {th }}$ minute etc. Similarly, if the sample is injected at $7^{\text {th }}$ minute, the product data will be obtained at $7^{\text {th }}, 15^{\text {th }}$, $23^{\text {rd }}, 31^{\text {th }}$ minute etc. Therefore, a series of experiments were conducted to get the product data at each minute in the time range. 
The profiles of $\mathrm{CO}_{2}, \mathrm{CO}$, and $\mathrm{H}_{2}$ from the reactor outlet for sorption-enhanced WGS over $\mathrm{HTS}-\mathrm{CaO}$, $\mathrm{HTS}-\mathrm{CaO} / \mathrm{Ca}_{12} \mathrm{Al}_{14} \mathrm{O}_{33}$ (75/25 wt \%), and HTS$\mathrm{CaO} / \mathrm{Ca}_{12} \mathrm{Al}_{14} \mathrm{O}_{33}(50 / 50$ wt \%) are given in Figures $22-24$ respectively. From the figures, it can be observed that the sorption-enhanced WGS reaction will proceed in three different phases: sorbent-enhancement (pre-breakthrough), sorbent breakthrough, and post- breakthrough steady-state operation.

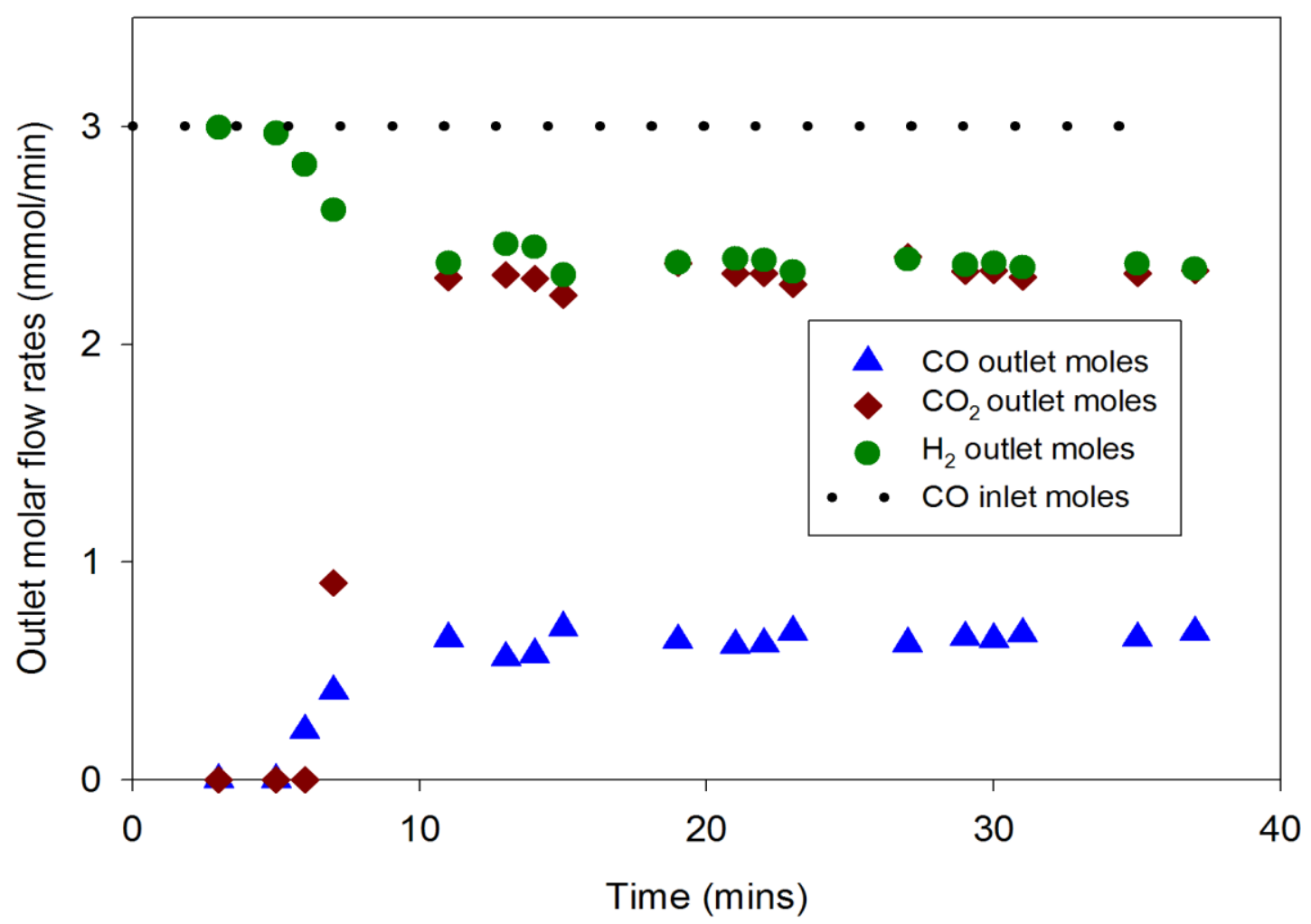

Figure 22. Profiles of product gases for sorption-enhanced WGS reaction over HTS$\mathrm{CaO}$ sorbent system $\left(\mathrm{T}: 500{ }^{\circ} \mathrm{C}\right.$, total flow: $380 \mathrm{sccm}, \mathrm{H}_{2} \mathrm{O} / \mathrm{CO}: 2, \mathrm{CO}: 17.54 \%$, He: $0.92 \%$, Ar: $\left.46.81 \%, \mathrm{H}_{2} \mathrm{O}: 34.67 \%\right)$.

During the sorbent enhancement phase, both WGS and the carbonation reactions are active, and hence the sorbent adsorbs nearly all of the $\mathrm{CO}_{2}$ produced. The $\mathrm{CO}$ in the outlet stream is negligible, and the amount of $\mathrm{H}_{2}$ produced is at its 
maximum during this period. For instance, in the case of the HTS-CaO system shown in Figure 22, no $\mathrm{CO}$ is detected in the outlet for upto 5 mins during the sorbent enhancement period. Similarly, for the HTS-CaO/Ca ${ }_{12} \mathrm{Al}_{14} \mathrm{O}_{33}(75 / 25$ wt \%) system, no CO is observed in the reactor outlet for upto 5 mins during this period. In the case of $\mathrm{HTS}-\mathrm{CaO} / \mathrm{Ca}_{12} \mathrm{Al}_{14} \mathrm{O}_{33}(50 / 50$ wt \%) system, no $\mathrm{CO}$ is observed in the reactor outlet for upto 3 mins.

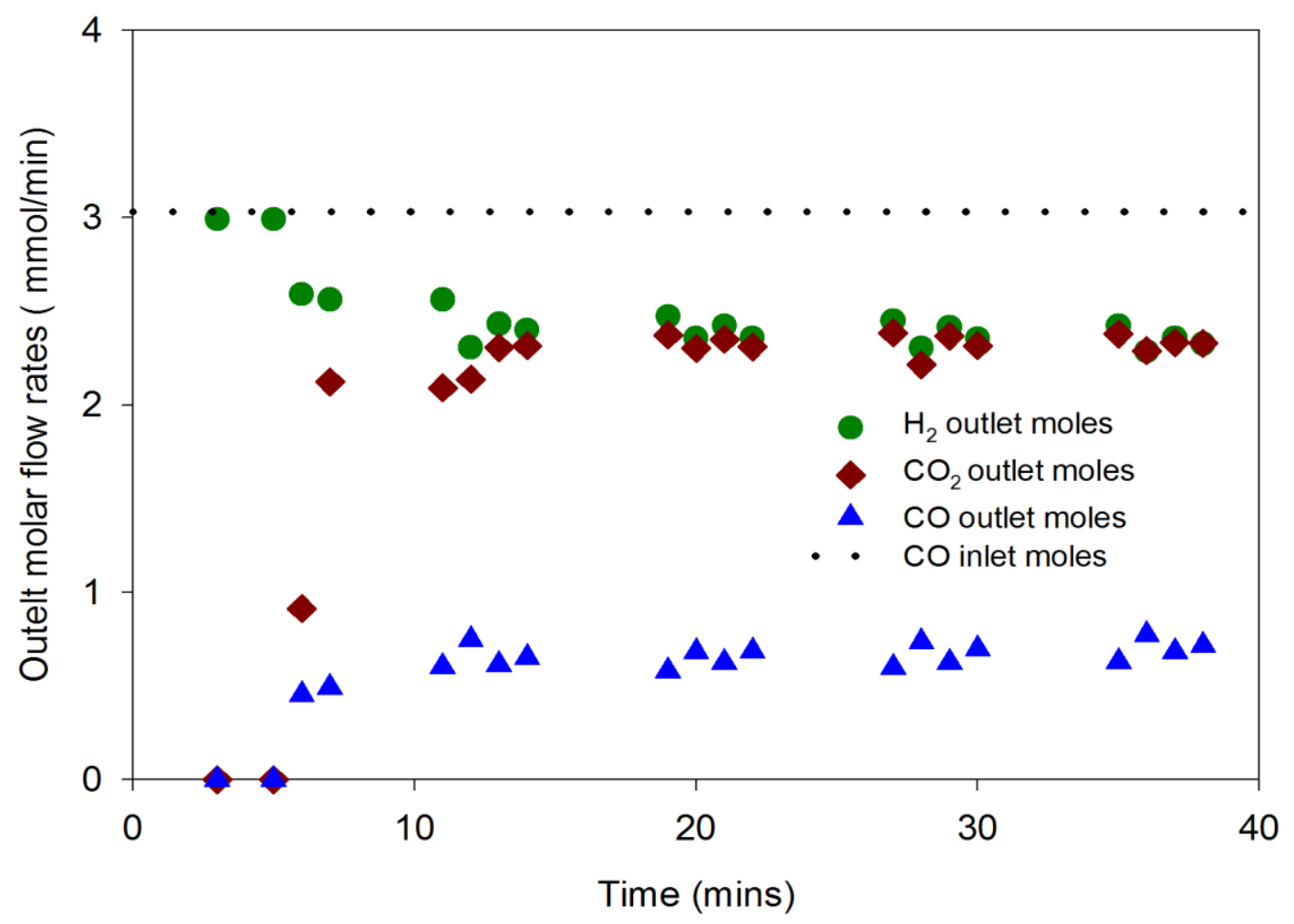

Figure 23. Profiles of product gases for SEWGS reaction over HTS catalyst$\mathrm{CaO} / \mathrm{Ca}_{12} \mathrm{Al}_{14} \mathrm{O}_{33}(75 / 25 \mathrm{wt} \%)$ sorbent system ( $\mathrm{T}: 500{ }^{\circ} \mathrm{C}$, total flow: $380 \mathrm{sccm}$, $\mathrm{H}_{2} \mathrm{O} / \mathrm{CO}: 2$, CO: $17.54 \%$, He: $0.92 \%$, Ar: $\left.46.81 \%, \mathrm{H}_{2} \mathrm{O}: 34.67 \%\right)$. 


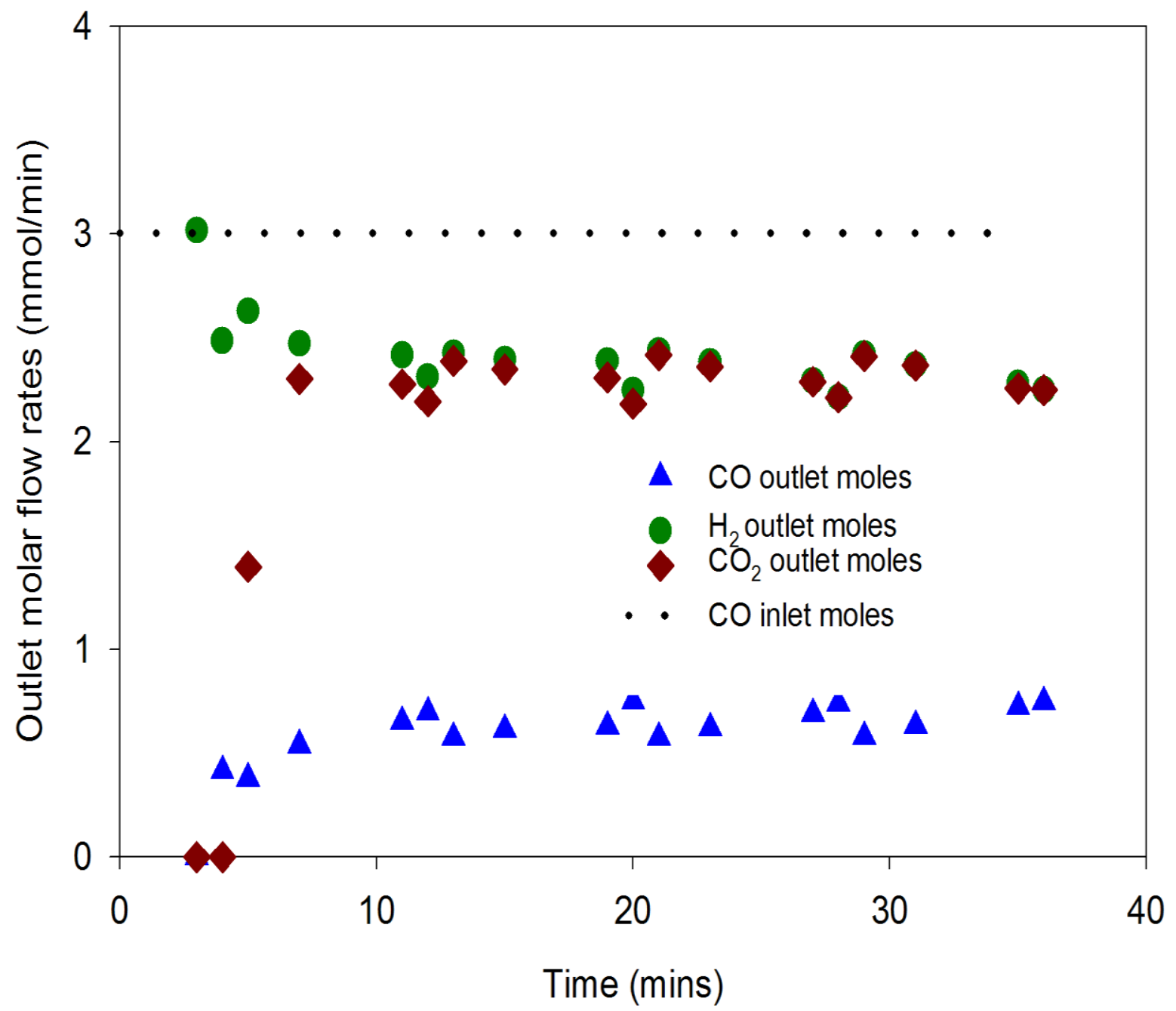

Figure 24. Profiles of product gases for SEWGS reaction over HTS catalyst$\mathrm{CaO} / \mathrm{Ca}_{12} \mathrm{Al}_{14} \mathrm{O}_{33}(50 / 50 \mathrm{wt} \%)$ sorbent system ( $\mathrm{T}: 500{ }^{\circ} \mathrm{C}$, total flow: $380 \mathrm{sccm}$, $\mathrm{H}_{2} \mathrm{O} / \mathrm{CO}: 2$, CO: $17.54 \%$, He: $0.919 \%$, Ar: $\left.46.808 \%, \mathrm{H}_{2} \mathrm{O}: 34.67 \%\right)$.

During the second, sorbent-breakthrough, phase, the activity of the carbonation reaction decreases due to the continuous use of sorbent. This leads to an increase in the $\mathrm{CO}$ outlet molar flow rate. For the HTS-CaO system, the $\mathrm{CO}$ outlet molar flow rate increases from approximately 0 to $0.72 \mathrm{mmol} / \mathrm{min}$ during the sorbentbreakthrough period which lasts approximately 35 minutes. The $\mathrm{H}_{2}$ outlet molar flow rate decreases from approximately $3.04 \mathrm{mmol} / \mathrm{min}$ to $2.38 \mathrm{mmol} / \mathrm{min}$, while $\mathrm{CO}_{2}$ 
outlet molar flow rate increases from approximately $0 \mathrm{mmol} / \mathrm{min}$ to $2.34 \mathrm{mmol} / \mathrm{min}$. This corresponds to a change in mole fraction for $\mathrm{H}_{2}$ from approximately $27.0 \mathrm{~mol} \%$ to $17.7 \mathrm{~mol} \%$ (dry basis) and for the $\mathrm{CO}_{2}$ from approximately $0 \mathrm{~mol} \%$ to $17.2 \mathrm{~mol} \%$ (dry basis).

For the $\mathrm{HTS}-\mathrm{CaO} / \mathrm{Ca}_{12} \mathrm{Al}_{14} \mathrm{O}_{33}(75 / 25$ wt \%) sorbent system, the sorbentbreakthrough period starts at the $6^{\text {th }}$ minute and ends approximately at the $29^{\text {th }}$ minute. The $\mathrm{CO}$ outlet molar flow rate increases from approximately 0 to 0.69 $\mathrm{mmol} / \mathrm{min}$ during this period. The $\mathrm{H}_{2}$ outlet molar flow rate decreases from approximately $3.04 \mathrm{mmol} / \mathrm{min}$ to $2.35 \mathrm{mmol} / \mathrm{min}$ while the $\mathrm{CO}_{2}$ outlet molar flow rate increases from approximately $0 \mathrm{mmol} / \mathrm{min}$ to $2.33 \mathrm{mmol} / \mathrm{min}$. This corresponds to a change in mole fraction for $\mathrm{H}_{2}$ from approximately $26.1 \mathrm{~mol} \%$ to $17.5 \mathrm{~mol} \%$ and for the $\mathrm{CO}_{2}$ from approximately $0 \mathrm{~mol} \%$ to $17.1 \mathrm{~mol} \%$ (all dry basis).

For the HTS-CaO/Ca ${ }_{12} \mathrm{Al}_{14} \mathrm{O}_{33}(50 / 50$ wt \%) system, the sorbent-breakthrough starts at the $4^{\text {th }}$ minute and ends at the $20^{\text {th }}$ minute. During this period, the CO outlet molar flow rate increases from approximately 0 to $0.70 \mathrm{mmol} / \mathrm{min}$. The $\mathrm{H}_{2}$ outlet molar flow rate decreases from approximately $3.04 \mathrm{mmol} / \mathrm{min}$ to $2.36 \mathrm{mmol} / \mathrm{min}$ while the $\mathrm{CO}_{2}$ outlet molar flow rate increases from approximately $0 \mathrm{mmol} / \mathrm{min}$ to $2.34 \mathrm{mmol} / \mathrm{min}$. This corresponds to a change in mole fraction for $\mathrm{H}_{2}$ from approximately $26.9 \mathrm{~mol} \%$ to $17.6 \mathrm{~mol} \%$ and for the $\mathrm{CO}_{2}$ from approximately $0 \mathrm{~mol} \%$ to $17.3 \mathrm{~mol} \%$ (all dry basis).

During the post-breakthrough period, the sorbent is nearly saturated, and hence there is little or no effect of sorbent presence on the CO conversion for WGS reaction. The comparisons of $\mathrm{CO}$ outlet molar flow rates for the WGS reaction over 
the catalyst alone and over the catalyst-sorbent mixtures are given in Figures 25, 26, and 27 for sorbents $\mathrm{CaO}, \mathrm{Ca}_{12} \mathrm{Al}_{14} \mathrm{O}_{33} 75 / 25$ wt \%, and $\mathrm{CaO} / \mathrm{Ca}_{12} \mathrm{Al}_{14} \mathrm{O}_{33} 50 / 50$ wt $\%$ respectively.

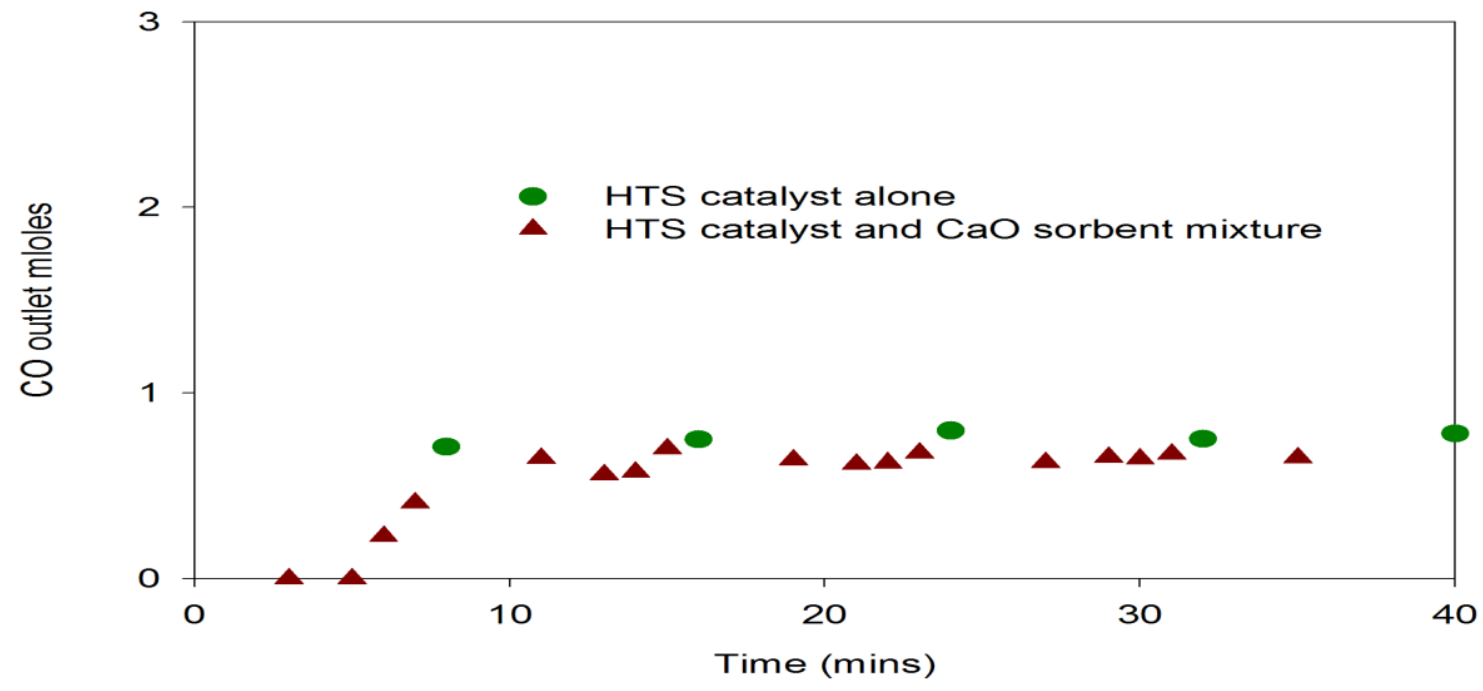

Figure 25. Comparison of $\mathrm{CO}$ outlet molar flow rates for WGS reaction over HTS catalyst- $\mathrm{CaO}$ sorbent mixture and $\mathrm{HTS}$ catalyst alone (Catalyst: $\mathrm{Fe}_{2} \mathrm{O}_{3} / \mathrm{Cr}_{2} \mathrm{O}_{3} / \mathrm{CuO}$, $\mathrm{T}: 500^{\circ} \mathrm{C}, \mathrm{H}_{2} \mathrm{O} / \mathrm{CO}: 2$, total flow: $\left.380 \mathrm{sccm}, \mathrm{P}: 1 \mathrm{~atm}\right)$.

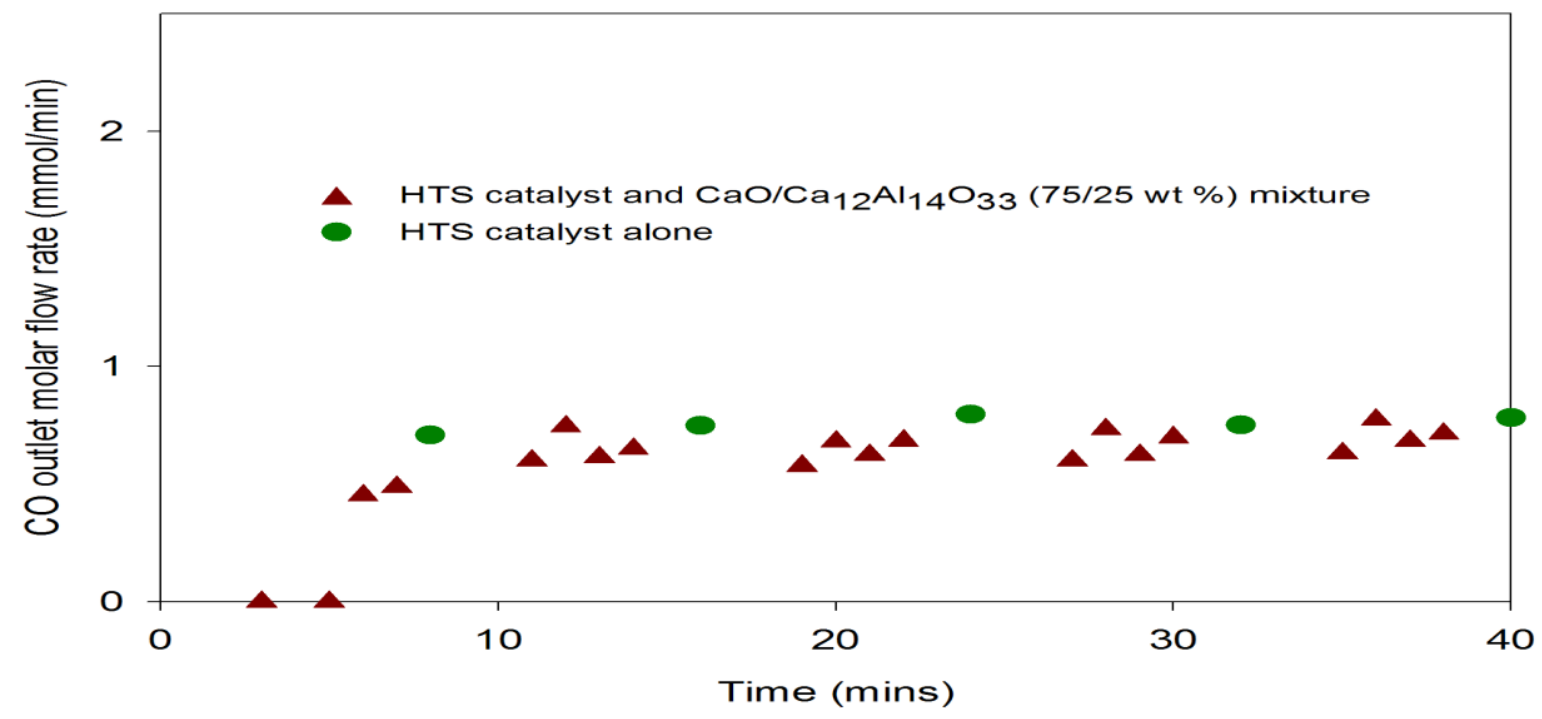

Figure 26. Comparison of $\mathrm{CO}$ outlet molar flow rates for WGS reaction over HTS catalyst- $\mathrm{CaO} / \mathrm{Ca}_{12} \mathrm{Al}_{14} \mathrm{O}_{33}(75 / 25 \mathrm{wt} \%)$ sorbent mixture and $\mathrm{HTS}$ catalyst alone. (Catalyst: $\mathrm{Fe}_{2} \mathrm{O}_{3} / \mathrm{Cr}_{2} \mathrm{O}_{3} / \mathrm{CuO}, \mathrm{T}: 500^{\circ} \mathrm{C}, \mathrm{H}_{2} \mathrm{O} / \mathrm{CO}: 2$, total flow: $380 \mathrm{sccm}, \mathrm{P}: 1 \mathrm{~atm}$ ). 


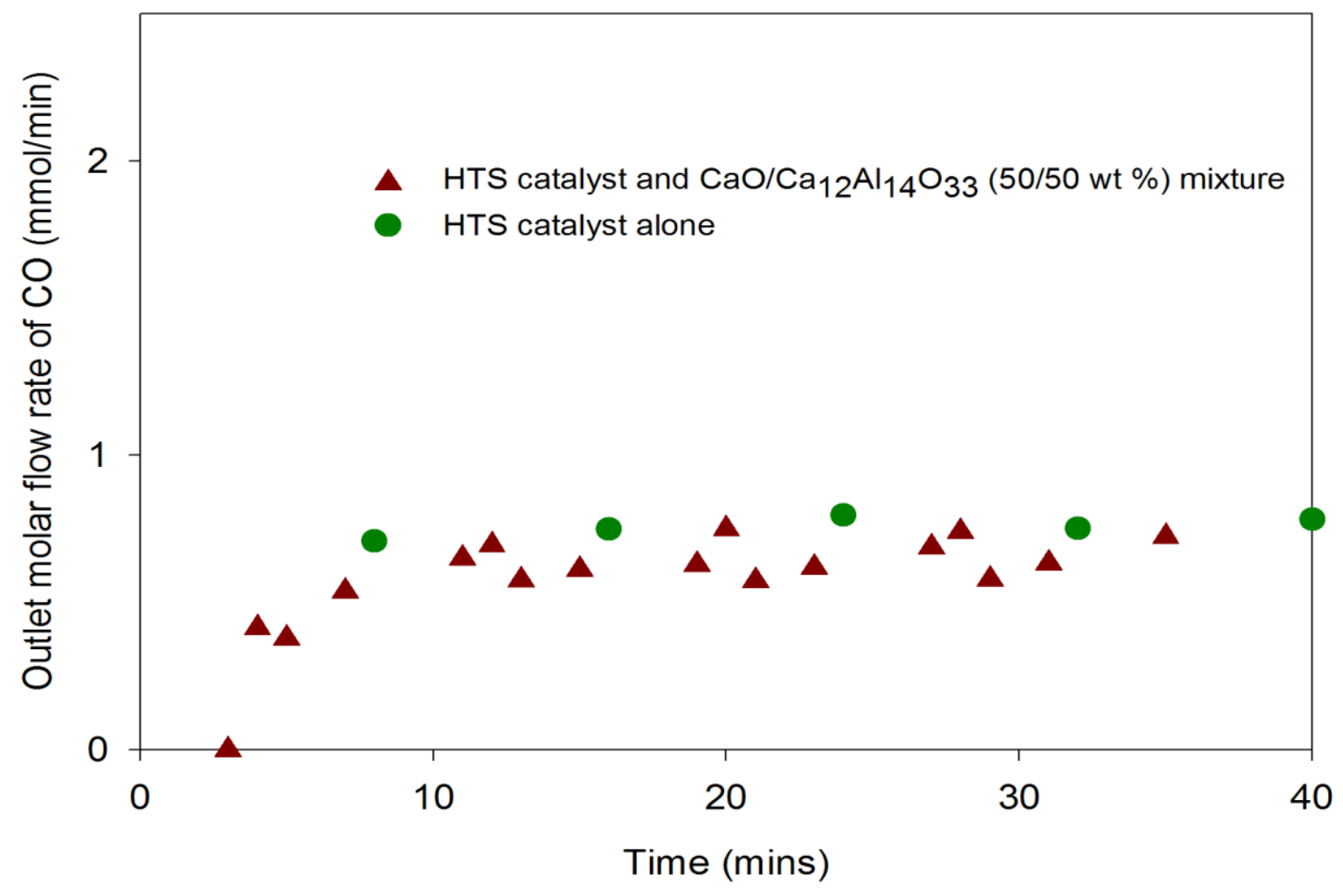

Figure 27. Comparison of $\mathrm{CO}$ outlet molar flow rates for WGS reaction over HTS catalyst- $\mathrm{CaO} / \mathrm{Ca}_{12} \mathrm{Al}_{14} \mathrm{O}_{33}(50 / 50$ wt \%) sorbent mixture and HTS catalyst alone. (Catalyst: $\mathrm{Fe}_{2} \mathrm{O}_{3} / \mathrm{Cr}_{2} \mathrm{O}_{3} / \mathrm{CuO}, \mathrm{T}: 500^{\circ} \mathrm{C}, \mathrm{H}_{2} \mathrm{O} / \mathrm{CO}: 2$, total flow: $380 \mathrm{sccm}, \mathrm{P}: 1 \mathrm{~atm}$ ).

The outlet flow rates in the presence of the sorbent are considerably lower in the first two stages and somewhat lower in the post-breakthrough period. It should be noted that, although Figures $22-27$ extend only up to $t=40$ minutes, the runs were carried out upto 120 mins. No significant changes were observed between 40 120 minutes.

The comparisons of $\mathrm{CO}_{2}$ outlet molar flow rates of WGS reaction over catalyst alone and the catalyst-sorbent mixture using sorbents $\mathrm{CaO}, \mathrm{Ca}_{12} \mathrm{Al}_{14} \mathrm{O}_{33} 75 / 25 \mathrm{wt} \%$, and $\mathrm{CaO} / \mathrm{Ca}_{12} \mathrm{Al}_{14} \mathrm{O}_{33} 50 / 50$ wt \% are given in Figures 28, 29, and 30 respectively. 


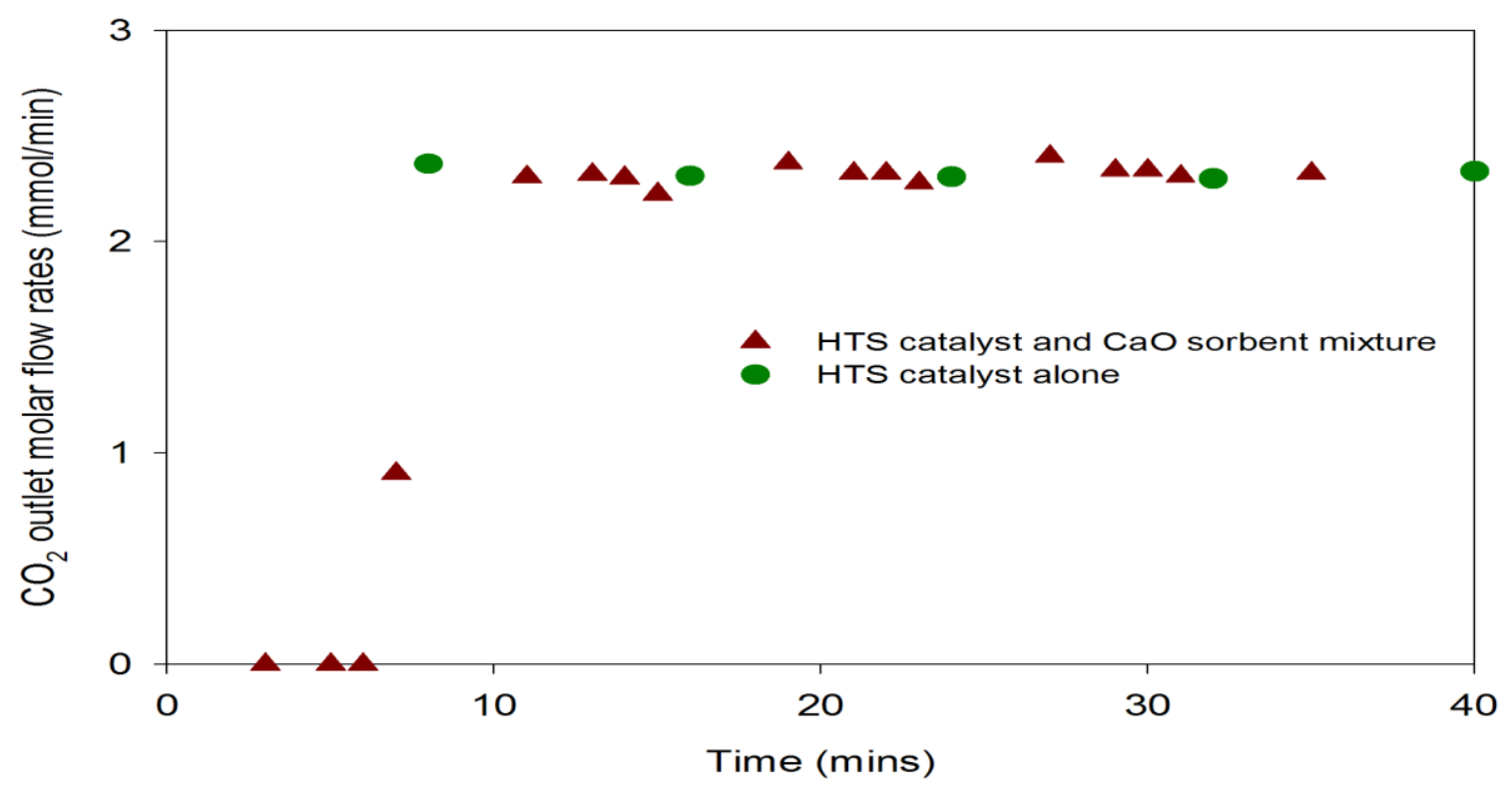

Figure 28. Comparison of $\mathrm{CO}_{2}$ outlet molar flow rates for WGS reaction over HTS catalyst-CaO sorbent mixture and HTS catalyst alone (Catalyst: $\mathrm{Fe}_{2} \mathrm{O}_{3} / \mathrm{Cr}_{2} \mathrm{O}_{3} / \mathrm{CuO}$, $\mathrm{T}: 500^{\circ} \mathrm{C}, \mathrm{H}_{2} \mathrm{O} / \mathrm{CO}: 2$, total flow: $\left.380 \mathrm{sccm}, \mathrm{P}: 1 \mathrm{~atm}\right)$.

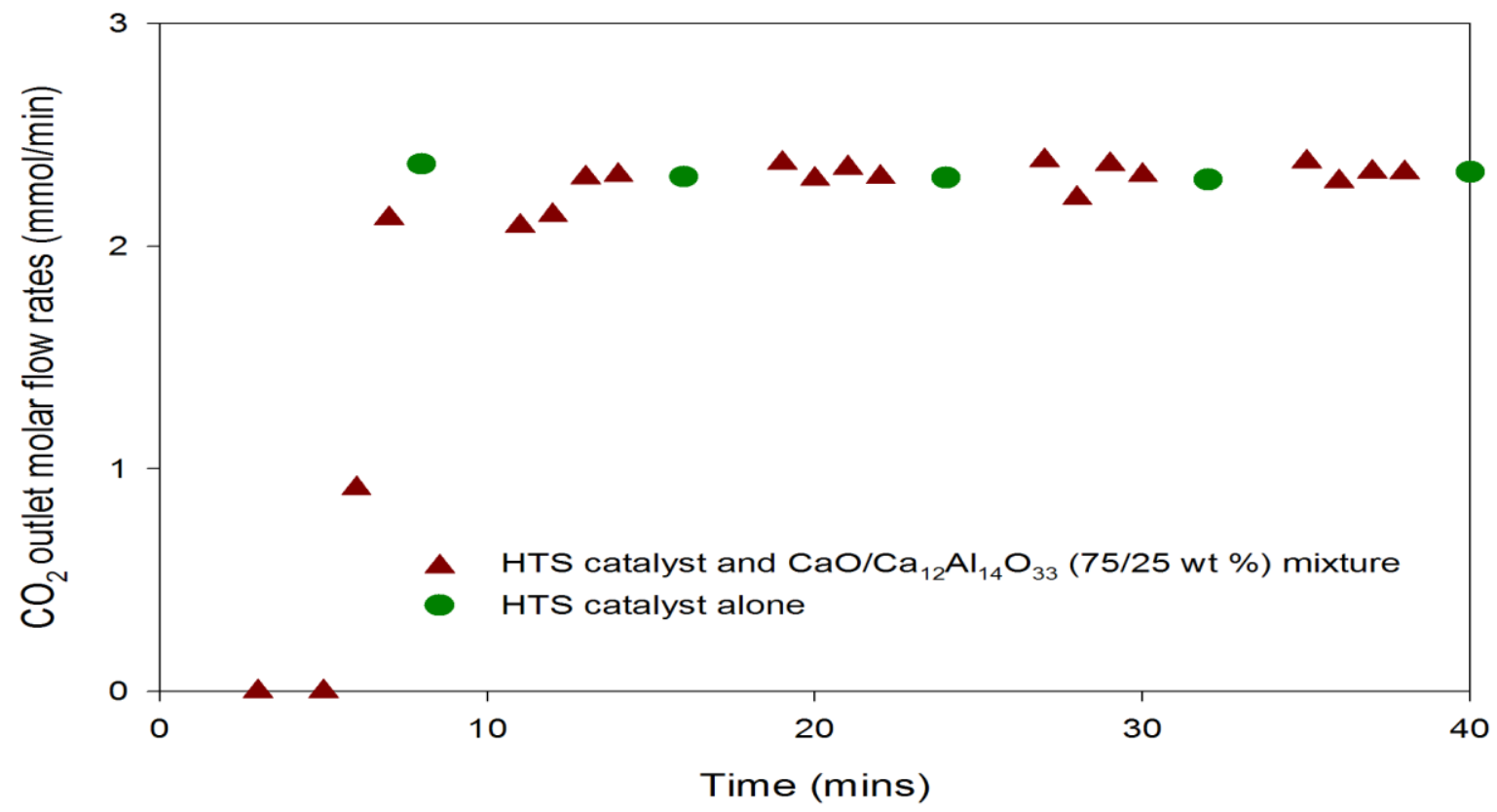

Figure 29. Comparison of $\mathrm{CO}_{2}$ outlet molar flow rates for WGS reaction over HTS catalyst- $\mathrm{CaO} / \mathrm{Ca}_{12} \mathrm{Al}_{14} \mathrm{O}_{33}(75 / 25 \mathrm{wt} \%)$ sorbent mixture and $\mathrm{HTS}$ catalyst alone. (Catalyst: $\mathrm{Fe}_{2} \mathrm{O}_{3} / \mathrm{Cr}_{2} \mathrm{O}_{3} / \mathrm{CuO}, \mathrm{T}: 500^{\circ} \mathrm{C}, \mathrm{H}_{2} \mathrm{O} / \mathrm{CO}: 2$, total flow: $380 \mathrm{sccm}, \mathrm{P}: 1 \mathrm{~atm}$ ). 


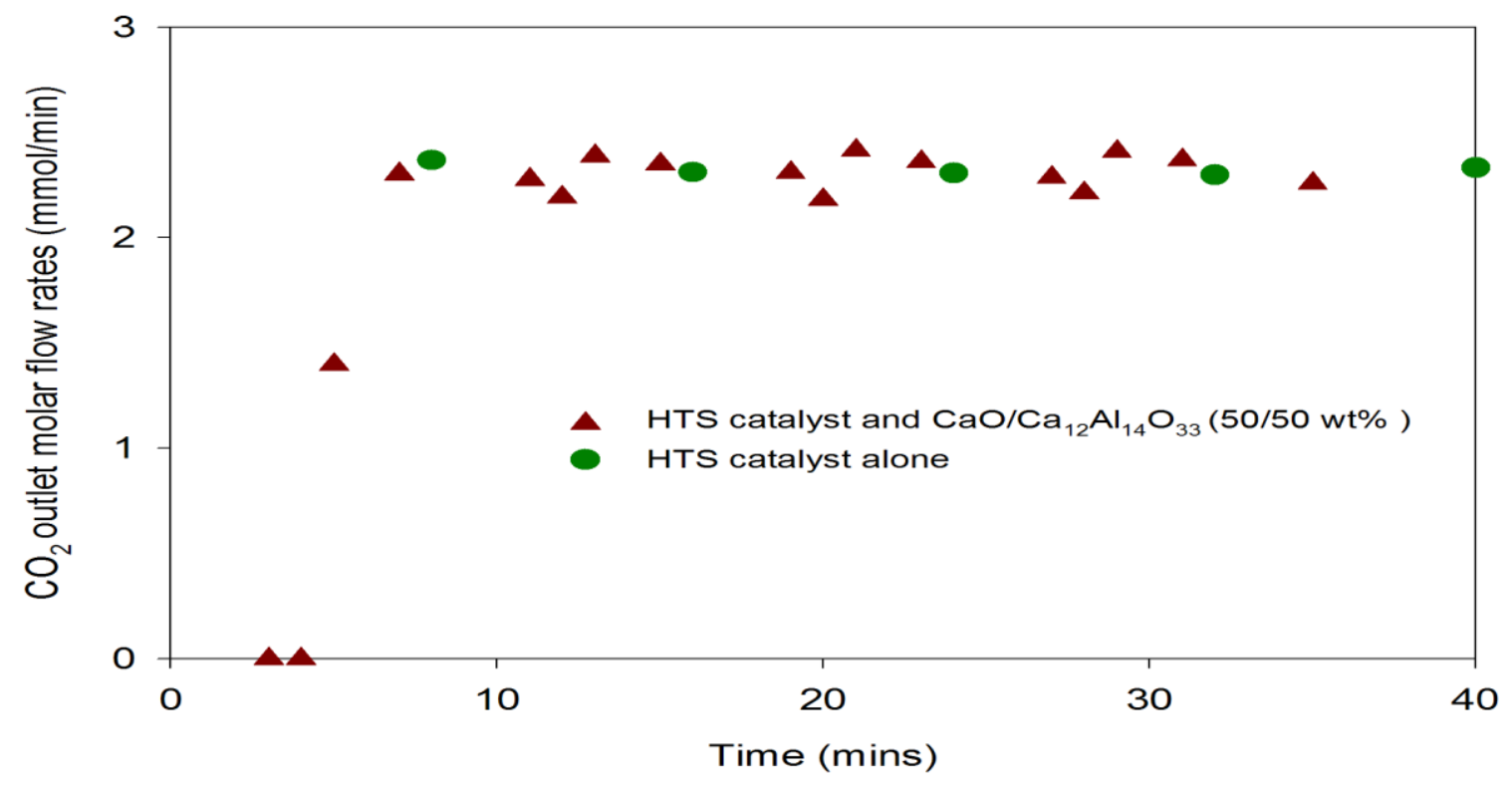

Figure 30. Comparison of $\mathrm{CO}_{2}$ outlet molar flow rates for WGS reaction over HTS catalyst- $\mathrm{CaO} / \mathrm{Ca}_{12} \mathrm{Al}_{14} \mathrm{O}_{33}(50 / 50$ wt \%) sorbent mixture and $\mathrm{HTS}$ catalyst alone. (Catalyst: $\mathrm{Fe}_{2} \mathrm{O}_{3} / \mathrm{Cr}_{2} \mathrm{O}_{3} / \mathrm{CuO}, \mathrm{T}: 500^{\circ} \mathrm{C}, \mathrm{H}_{2} \mathrm{O} / \mathrm{CO}: 2$, total flow: $380 \mathrm{sccm}, \mathrm{P}: 1 \mathrm{~atm}$ ).

\subsubsection{HTS catalyst and sorbent separated with chips}

Experiments were also conducted keeping the catalyst and the sorbents as different beds separated by quartz chips. HTS catalyst $(0.2 \mathrm{~g})$ was diluted with quartz chips with a ratio of $1: 4$ and sorbent $(2.5 \mathrm{~g})$ was diluted with a ratio of 1:2. Subsequently, the catalyst-sorbent system was reduced at $300^{\circ} \mathrm{C}$ using $\mathrm{H}_{2} / \mathrm{Ar}(10 / 90$ \%) with a total flow of $170 \mathrm{sccm}$ for 2 hours. Then the system was purged with argon for 2 hours in order to remove any trace amounts of hydrogen present on the surface of the HTS catalyst. Finally, the reaction gas mixture with a composition of CO$17.54 \%$, $\mathrm{He}-0.92 \%, \mathrm{H}_{2} \mathrm{O}-34.67 \%$, and $\mathrm{Ar}-46.87 \%$ was allowed to flow through the system.

The reaction was conducted for approximately 2 hours. The GC continuously monitored the flow of product gases from reactor outlet with an interval of $8 \mathrm{~min}$. The 
comparison of outlet molar flow rates of CO for WGS reaction over HTS catalyst alone with HTS-CaO sorbent separated by quartz chips is shown in Figure 31 . The comparisons of outlet molar flow rates of $\mathrm{CO}$ for sorbents $\mathrm{CaO} / \mathrm{Ca}_{12} \mathrm{Al}_{14} \mathrm{O}_{33},(75 / 25$ wt $\%$ and 50/50 wt \%)) are shown in Figures 32 and 33, respectively.

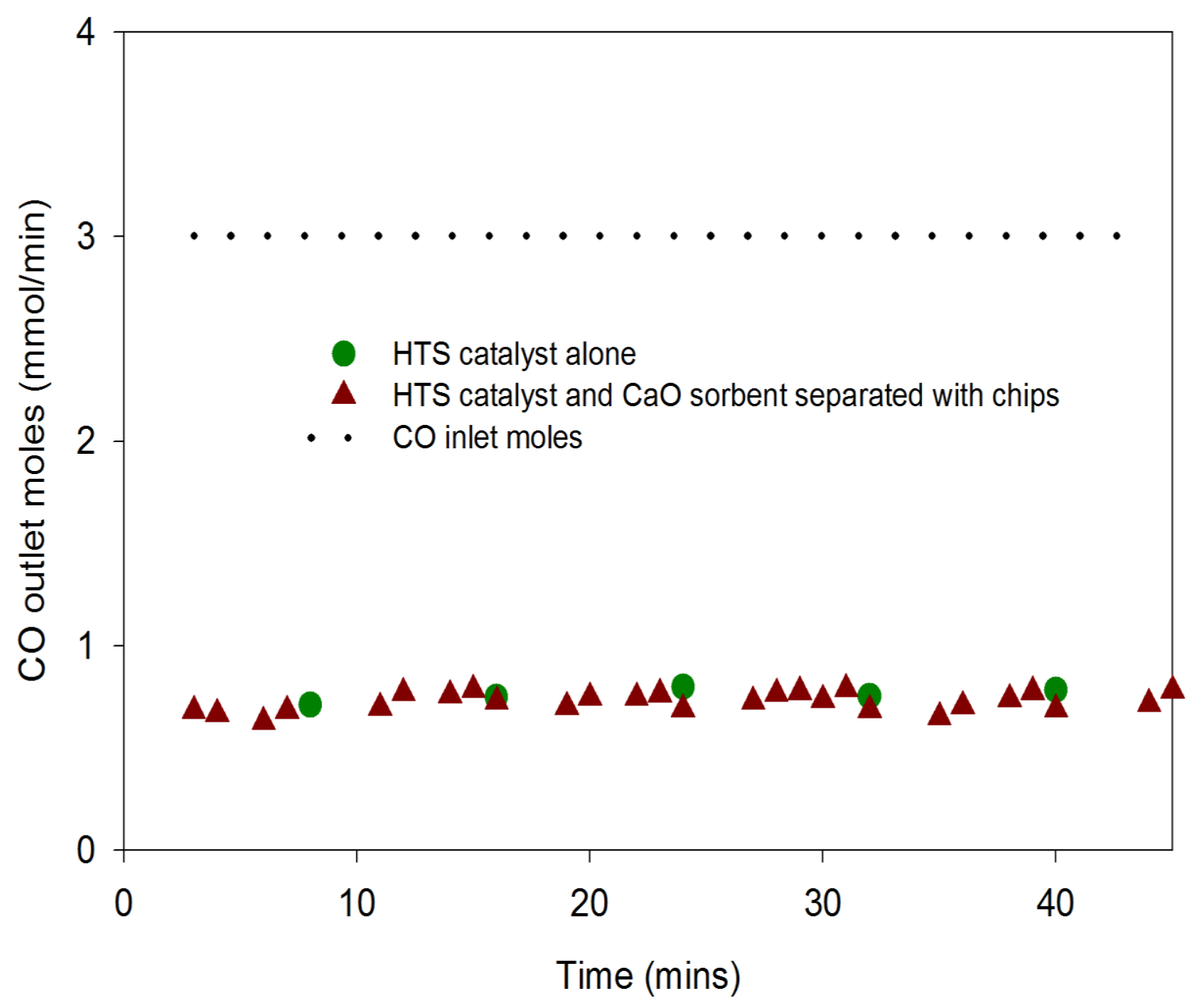

Figure 31. Comparison of $\mathrm{CO}$ outlet molar flow rates for WGS reaction during the HTS catalyst and $\mathrm{CaO}$ sorbent separated with chips and HTS catalyst alone (Catalyst: $\mathrm{Fe}_{2} \mathrm{O}_{3} / \mathrm{Cr}_{2} \mathrm{O}_{3} / \mathrm{CuO}$, sorbent: $\mathrm{CaO}, \mathrm{T}: 500^{\circ} \mathrm{C}, \mathrm{H}_{2} \mathrm{O} / \mathrm{CO}$ : 2, total flow: 380 sccm, P: $1 \mathrm{~atm})$. 


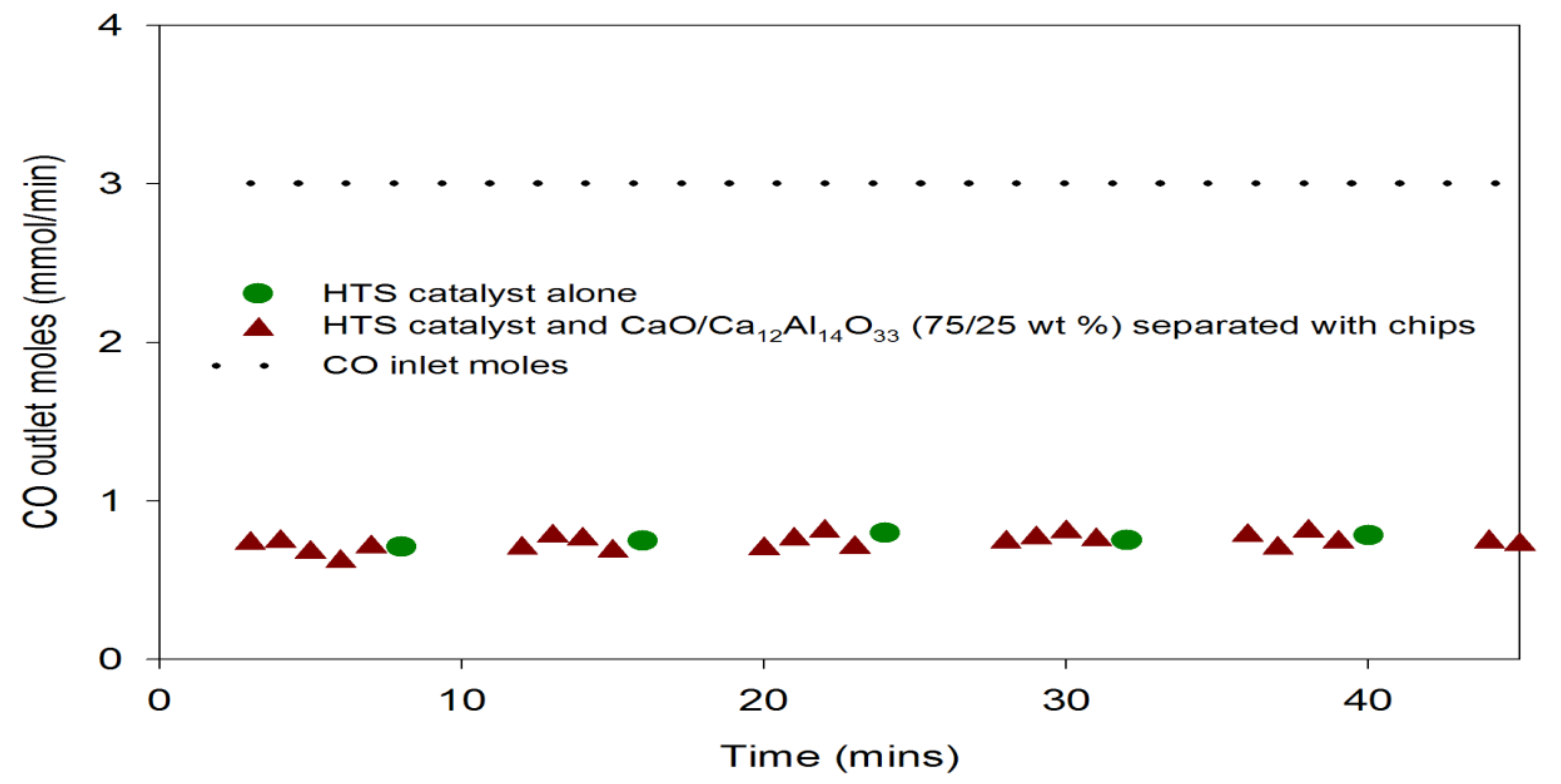

Figure 32. Comparison of $\mathrm{CO}$ outlet molar flow rates for WGS reaction during the HTS catalyst and $\mathrm{CaO} / \mathrm{Ca}_{12} \mathrm{Al}_{14} \mathrm{O}_{33}(75 / 25 \mathrm{wt} \%)$ sorbent separated with chips and HTS catalyst alone (Catalyst: $\mathrm{Fe}_{2} \mathrm{O}_{3} / \mathrm{Cr}_{2} \mathrm{O}_{3} / \mathrm{CuO}, \mathrm{T}: 500^{\circ} \mathrm{C}, \mathrm{H}_{2} \mathrm{O} / \mathrm{CO}$ : 2, total flow: $380 \mathrm{sccm}, \mathrm{P}: 1 \mathrm{~atm})$.

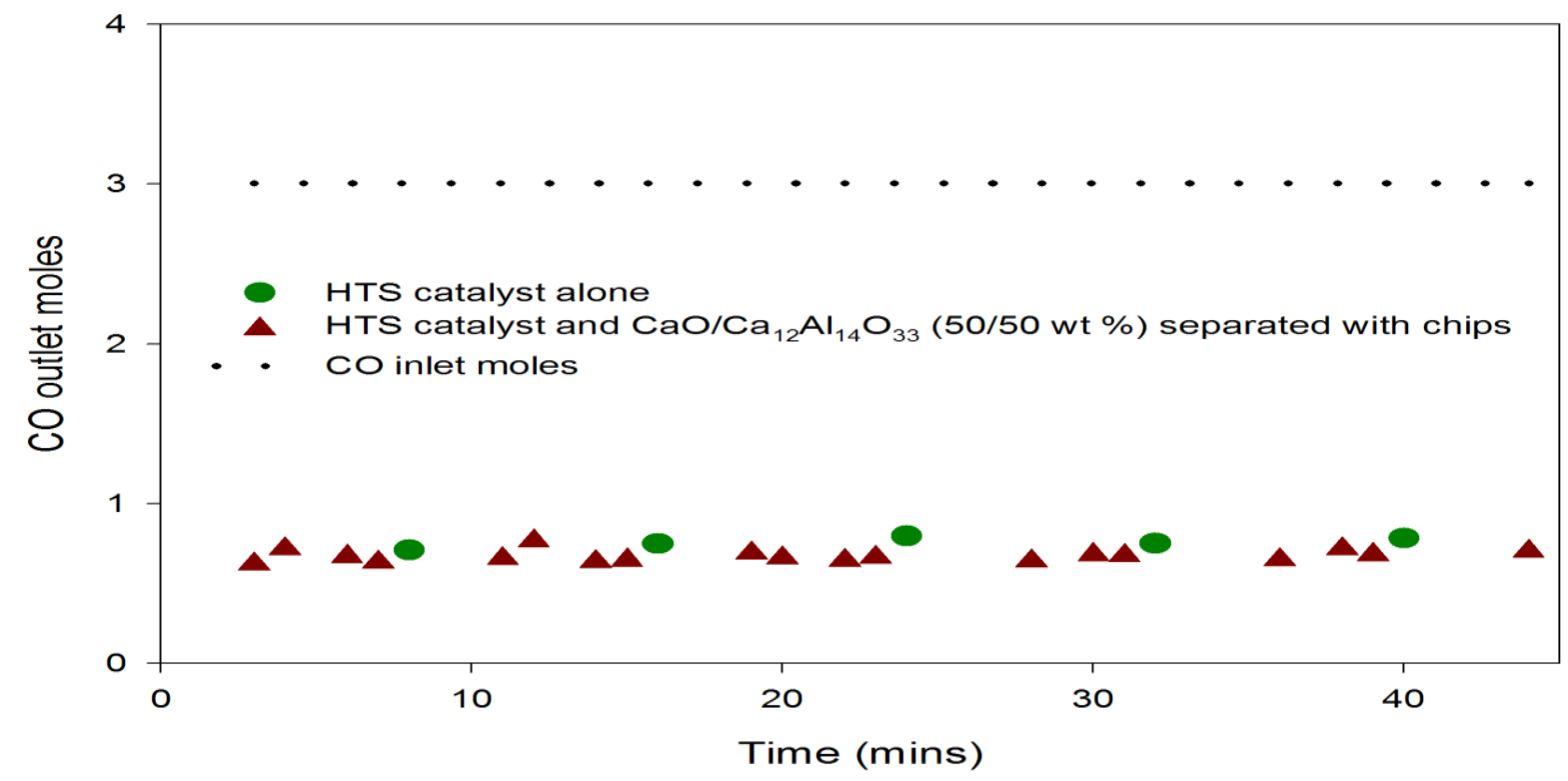

Figure 33. Comparison of $\mathrm{CO}$ outlet molar flow rates for WGS reaction during the HTS catalyst and $\mathrm{CaO} / \mathrm{Ca}_{12} \mathrm{Al}_{14} \mathrm{O}_{33}(50 / 50 \mathrm{wt} \%)$ sorbent separated with chips and HTS catalyst alone (Catalyst: $\mathrm{Fe}_{2} \mathrm{O}_{3} / \mathrm{Cr}_{2} \mathrm{O}_{3} / \mathrm{CuO}, \mathrm{T}: 500^{\circ} \mathrm{C}, \mathrm{H}_{2} \mathrm{O} / \mathrm{CO}$ : 2, total flow: $380 \mathrm{sccm}, \mathrm{P}: 1 \mathrm{~atm})$. 
From Figures 31, 32, and 33, it can be observed that the presence of sorbent in the reactor as a separate bed affects $\mathrm{CO}$ outlet flow rates to a negligible extent, compared to the HTS catalyst alone. According to Le Chatelier's principle, removal of the $\mathrm{CO}_{2}$ product from the reaction zone should drive the reaction in the forward direction. But in the present case, the sorbent is not present in the reaction zone.

The corresponding product profiles are shown in Figures 34-36, respectively. From the figures, it is observed that the adsorption of $\mathrm{CO}_{2}$ with sorbents will occur in three different phases similar to those for catalyst-sorbent mixture: the prebreakthrough period, sorbent-breakthrough, and post-breakthrough steady-state operation.

During the pre-breakthrough period, the $\mathrm{CaO}$ sorbent adsorbs all the $\mathrm{CO}_{2}$ formed for the first 7 minutes while the $\mathrm{CaO} / \mathrm{Ca}_{12} \mathrm{Al}_{14} \mathrm{O}_{33}(75 / 25$ wt \%) sorbent adsorbs all the $\mathrm{CO}_{2}$ formed for the initial 6 minutes. The $\mathrm{CaO} / \mathrm{Ca}_{12} \mathrm{Al}_{14} \mathrm{O}_{33}(50 / 50 \mathrm{wt}$ \%) sorbent adsorbs all the $\mathrm{CO}_{2}$ formed for the first 3 mins. The $\mathrm{CO}_{2}$ breakthrough begins at the $8^{\text {th }}$ minute for the $\mathrm{CaO}$ sorbent, at the $7^{\text {th }}$ minute for $\mathrm{CaO} / \mathrm{Ca}_{12} \mathrm{Al}_{14} \mathrm{O}_{33}$ (75/25 wt \%), and at the $4^{\text {th }}$ minute for $\mathrm{CaO} / \mathrm{Ca}_{12} \mathrm{Al}_{14} \mathrm{O}_{33}(50 / 50 \mathrm{wt} \%)$ sorbent.

The $\mathrm{CO}_{2}$ concentration increases rapidly for all three sorbents until the postbreakthrough steady state is reached. In the case of the $\mathrm{CaO}$ sorbent, the $\mathrm{CO}_{2}$ outlet molar flow rate increases from $0 \mathrm{mmol} / \mathrm{min}$ to $2.81 \mathrm{mmol} / \mathrm{min}$ and finally reaches the post-breakthrough period approximately at the $45^{\text {th }}$ minute. Similarly, the $\mathrm{CO}_{2}$ outlet molar flow rate increases from $0 \mathrm{mmol}$ to $2.33 \mathrm{mmol} / \mathrm{min}$ for the $\mathrm{CaO} / \mathrm{Ca}_{12} \mathrm{Al}_{14} \mathrm{O}_{33}$ (75/25 wt \%) sorbent and reaches the post-breakthrough period at approximately the $36^{\text {th }}$ minute. For the $\mathrm{CaO} / \mathrm{Ca}_{12} \mathrm{Al}_{14} \mathrm{O}_{33}\left(50 / 50\right.$ wt \%) sorbent, the $\mathrm{CO}_{2}$ outlet molar 
flow rate increases from $0 \mathrm{mmol} / \mathrm{min}$ to $2.36 \mathrm{mmol} / \mathrm{min}$ during the sorbentbreakthrough period which ends approximately at the $28^{\text {th }}$ minute. During the postbreakthrough period, the sorbents are completely saturated and the $\mathrm{CO}_{2}$ moles obtained are approximately the same as that of HTS catalyst alone.

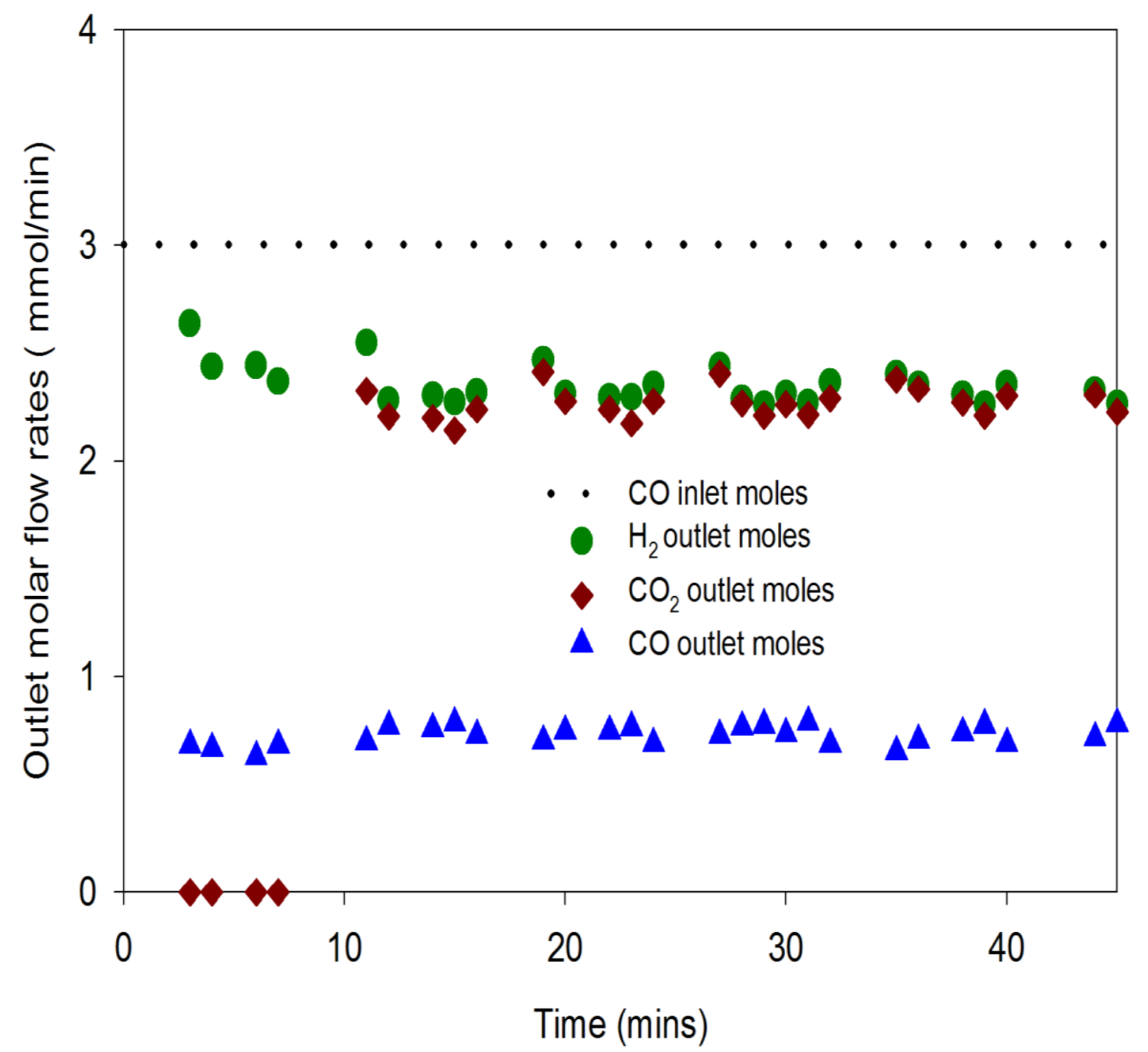

Figure 34. Profiles of product gases for $\mathrm{HTS}$ catalyst and $\mathrm{CaO}$ sorbent separated with chips $\left(\mathrm{T}: 500{ }^{\circ} \mathrm{C}\right.$, total flow: $380 \mathrm{sccm}, \mathrm{H}_{2} \mathrm{O} / \mathrm{CO}: 2$, CO: $17.54 \%$, He: $0.92 \%$, Ar: $\left.46.81 \%, \mathrm{H}_{2} \mathrm{O}: 34.67 \%\right)$. 


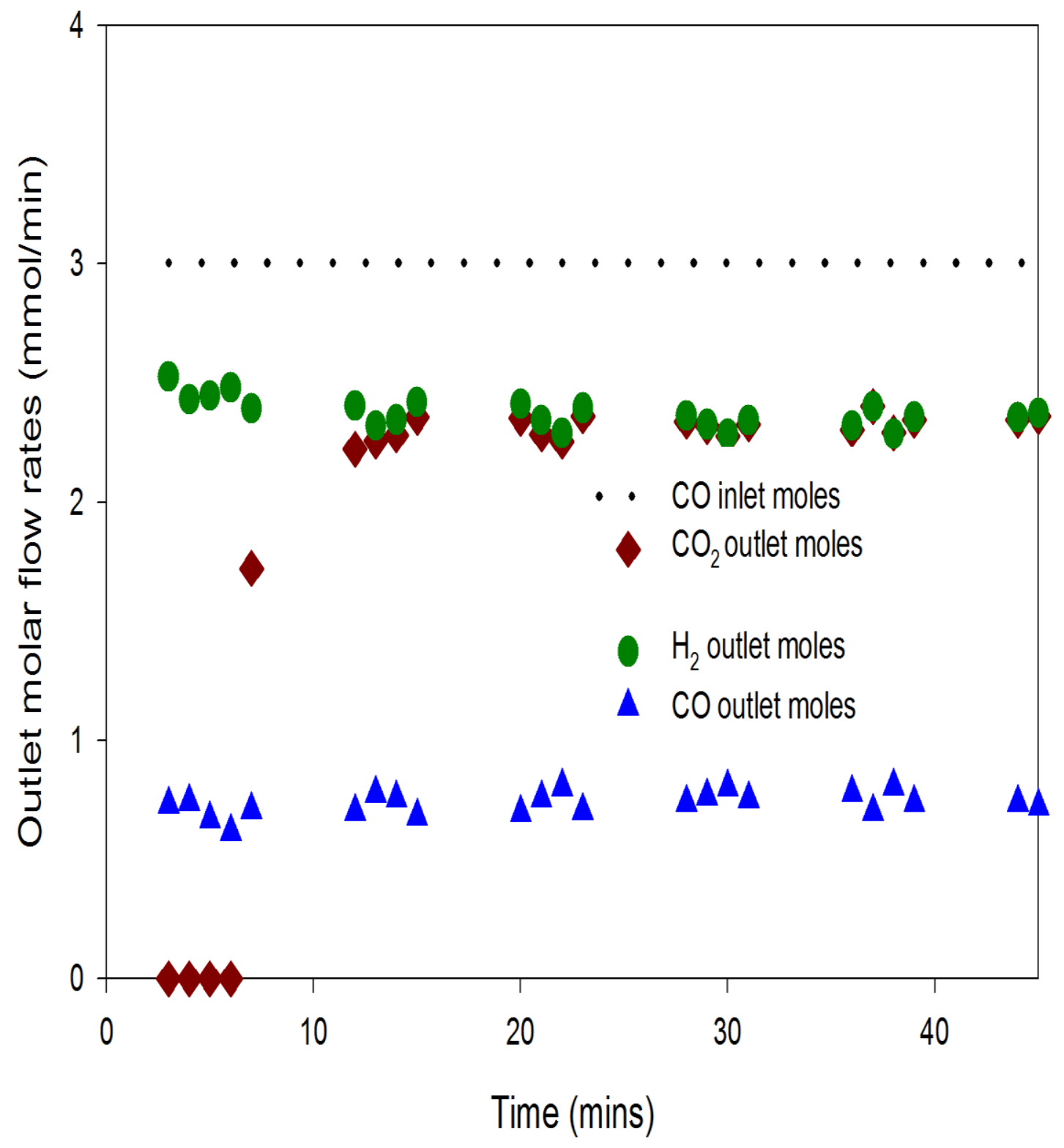

Figure 35. Profiles of product gases for $\mathrm{HTS}$ catalyst and $\mathrm{CaO} / \mathrm{Ca}_{12} \mathrm{Al}_{14} \mathrm{O}_{33}(75 / 25 \mathrm{wt}$ $\%)$ sorbent separated with chips ( $\mathrm{T}: 500{ }^{\circ} \mathrm{C}$, total flow: $380 \mathrm{sccm}, \mathrm{H}_{2} \mathrm{O} / \mathrm{CO}: 2, \mathrm{CO}$ : $17.54 \%$, He: $0.92 \%$, Ar: $46.81 \%, \mathrm{H}_{2} \mathrm{O}: 34.67 \%$ ). 


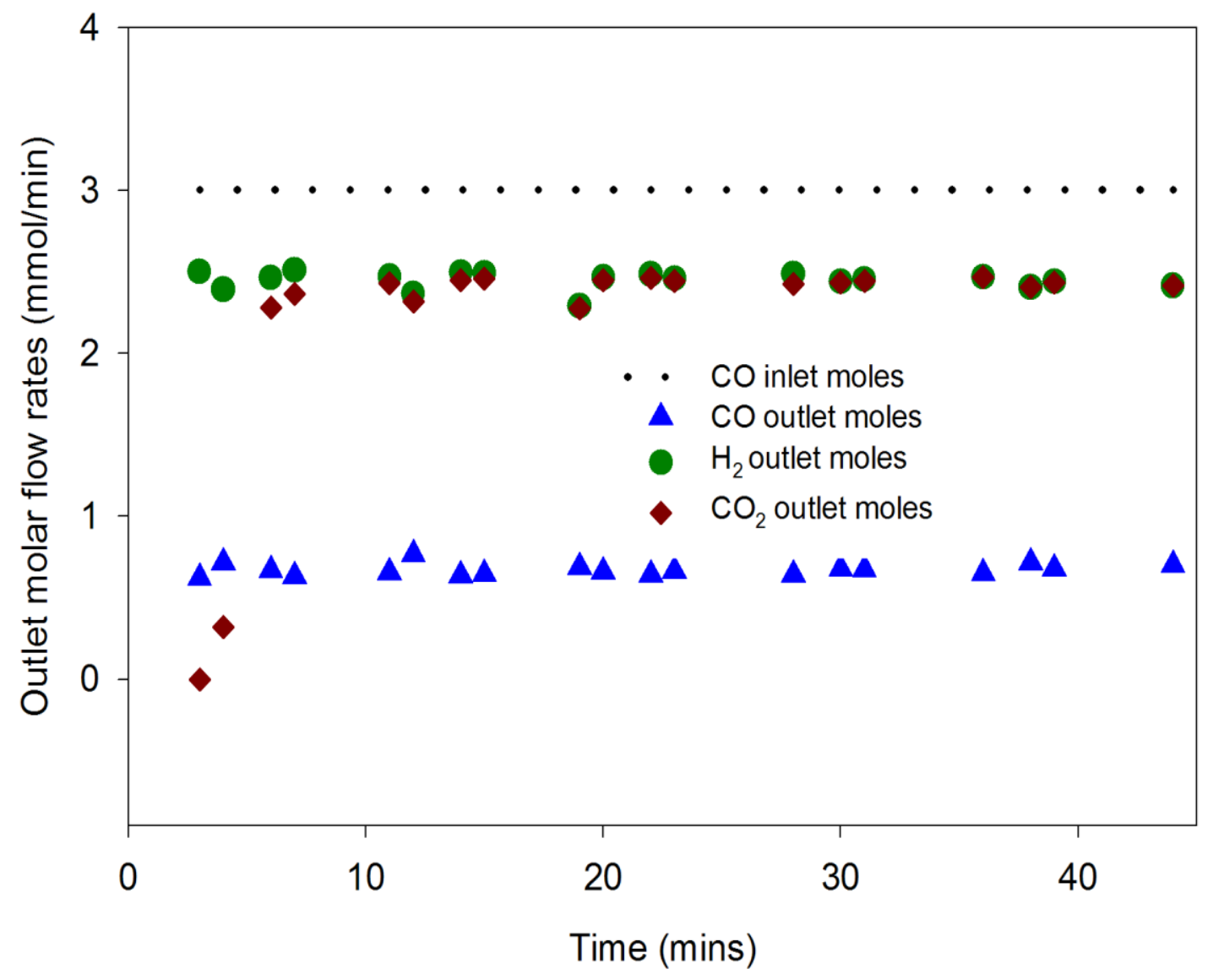

Figure 36. Profiles of product gases for $\mathrm{HTS}$ catalyst and $\mathrm{CaO} / \mathrm{Ca}_{12} \mathrm{Al}_{14} \mathrm{O}_{33}(50 / 50 \mathrm{wt}$ $\%$ ) sorbent separated with chips ( $\mathrm{T}: 500{ }^{\circ} \mathrm{C}$, total flow: $380 \mathrm{sccm}, \mathrm{H}_{2} \mathrm{O} / \mathrm{CO}: 2, \mathrm{CO}$ : $17.54 \%$, He: $0.92 \%$, Ar: $46.81 \%, \mathrm{H}_{2} \mathrm{O}: 34.67 \%$ ).

\subsubsection{Comparison of products with varying reactor contents}

The $\mathrm{CO}_{2}$ product profiles of WGS reaction over HTS catalyst, catalyst and sorbent ( $\mathrm{CaO}, \mathrm{Ca}_{12} \mathrm{Al}_{14} \mathrm{O}_{33}$ (75/25 wt\%, 50/50 wt \%)) separated with chips, and the catalyst-sorbent mixture are given in Figures 37,38 , and 39 respectively. Similarly, the profiles of $\mathrm{H}_{2}$ are given in Figures 40, 41, and 42.

From Figures 37-39, it is observed that the presence of the sorbent enhances the rate of formation of $\mathrm{CO}_{2}$ at short times, in the pre-breakthrough period, by 
simultaneously adsorbing the $\mathrm{CO}_{2}$ produced from WGS reaction. This leads to production of high amount of pure hydrogen in the pre-breakthrough period, as shown in Figures 40-42. This trend is observed in all the three sorbents. Since the amount of reactive material in three sorbents is not the same, the pre-breakthrough period for three sorbents is different. However, the presence of sorbent in the reactor does not affect the production of $\mathrm{CO}_{2}$ or $\mathrm{H}_{2}$ in the post-breakthrough period, compared to HTS catalyst alone.

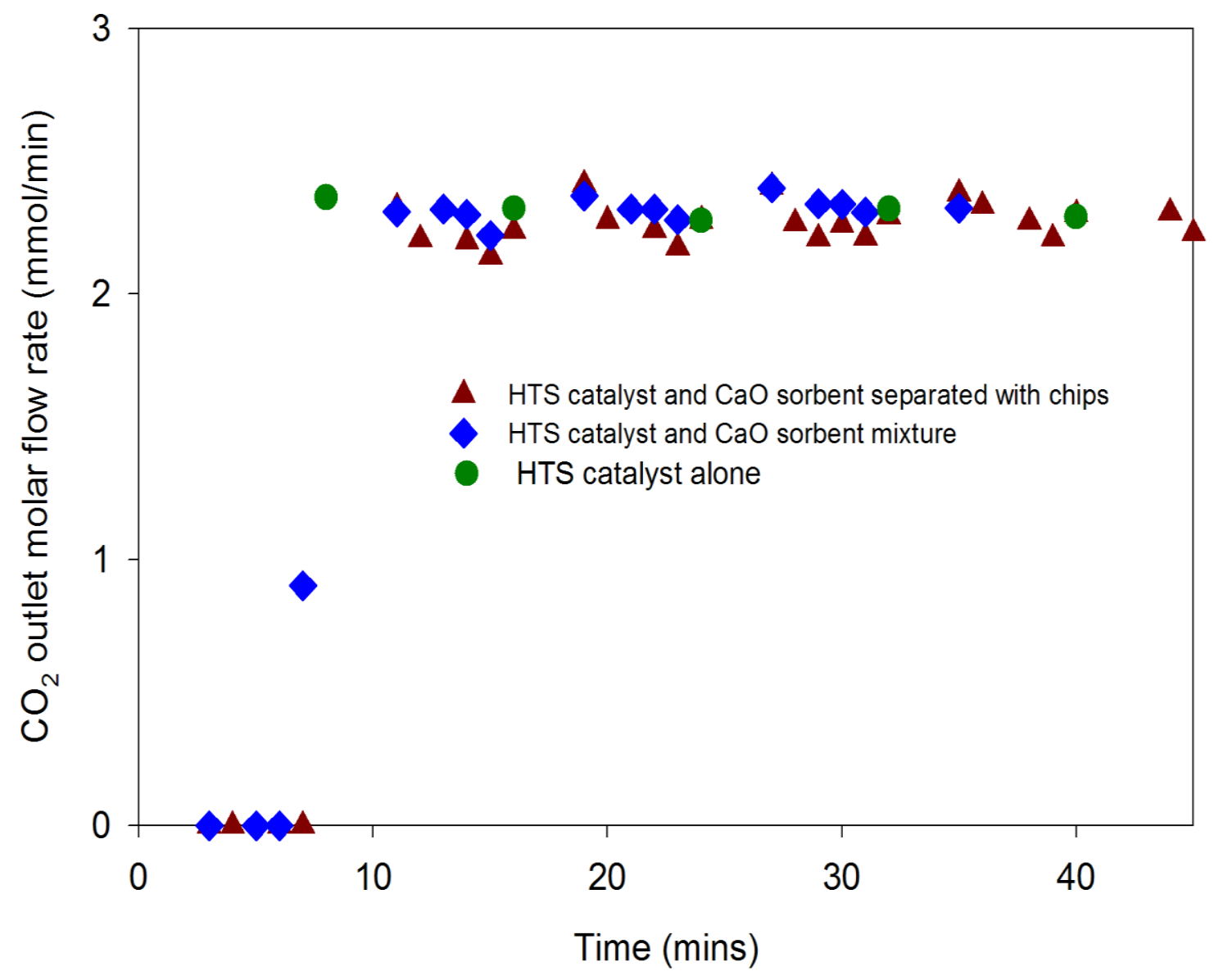

Figure 37. Profiles of $\mathrm{CO}_{2}$ for WGS reaction over HTS-CaO in both modes and $\mathrm{HTS}$ catalyst alone ( $\mathrm{T}: 500^{\circ} \mathrm{C}$, total flow: $380 \mathrm{sccm}, \mathrm{H}_{2} \mathrm{O} / \mathrm{CO}: 2$ ) 


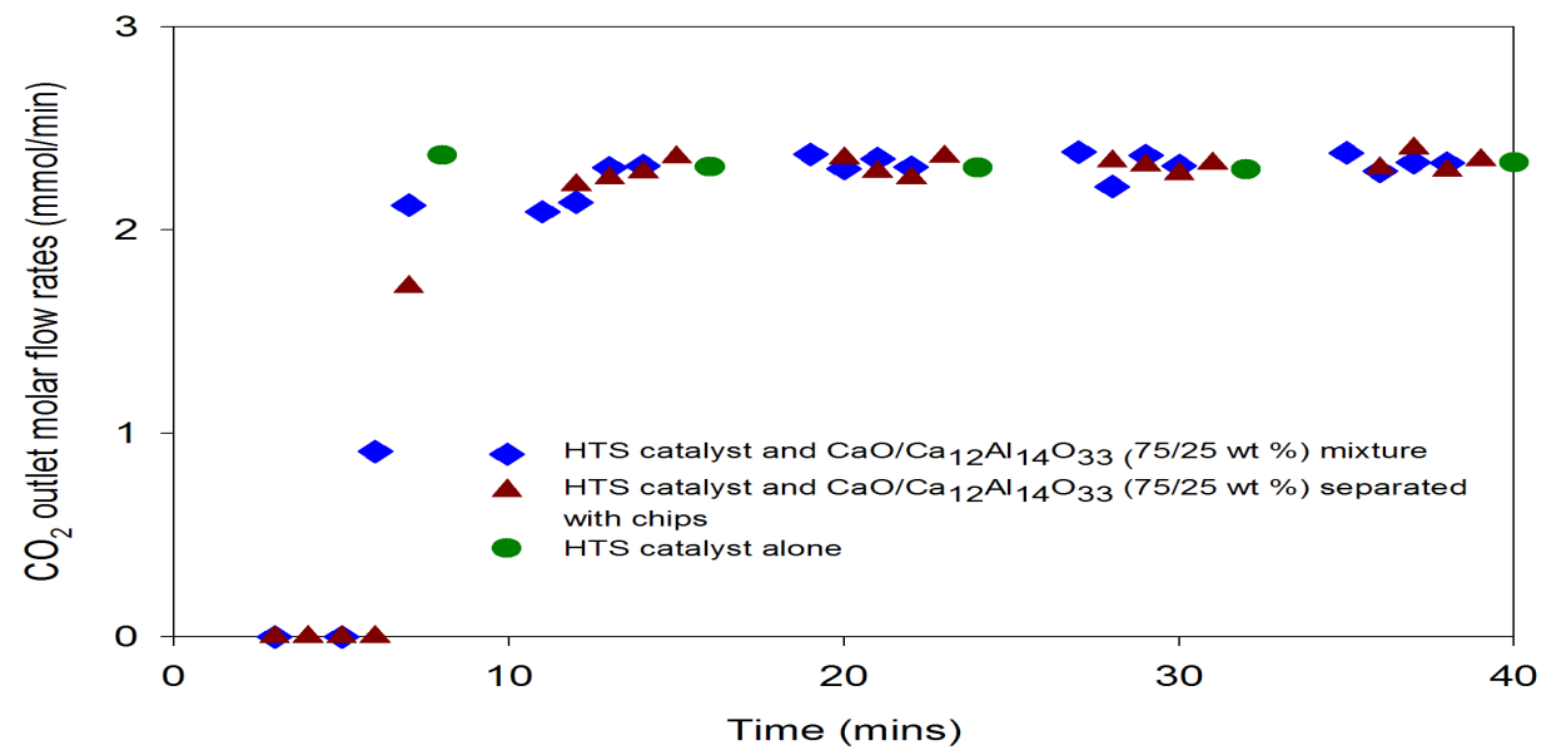

Figure 38. Profiles of $\mathrm{CO}_{2}$ for WGS reaction over $\mathrm{HTS}-\mathrm{CaO} / \mathrm{Ca}_{12} \mathrm{Al}_{14} \mathrm{O}_{33}(75 / 25 \mathrm{wt}$ $\%)$ in both modes and HTS catalyst alone $\left(\mathrm{T}: 500^{\circ} \mathrm{C}\right.$, total flow: $380 \mathrm{sccm}$, $\mathrm{H}_{2} \mathrm{O} / \mathrm{CO}: 2$ ).

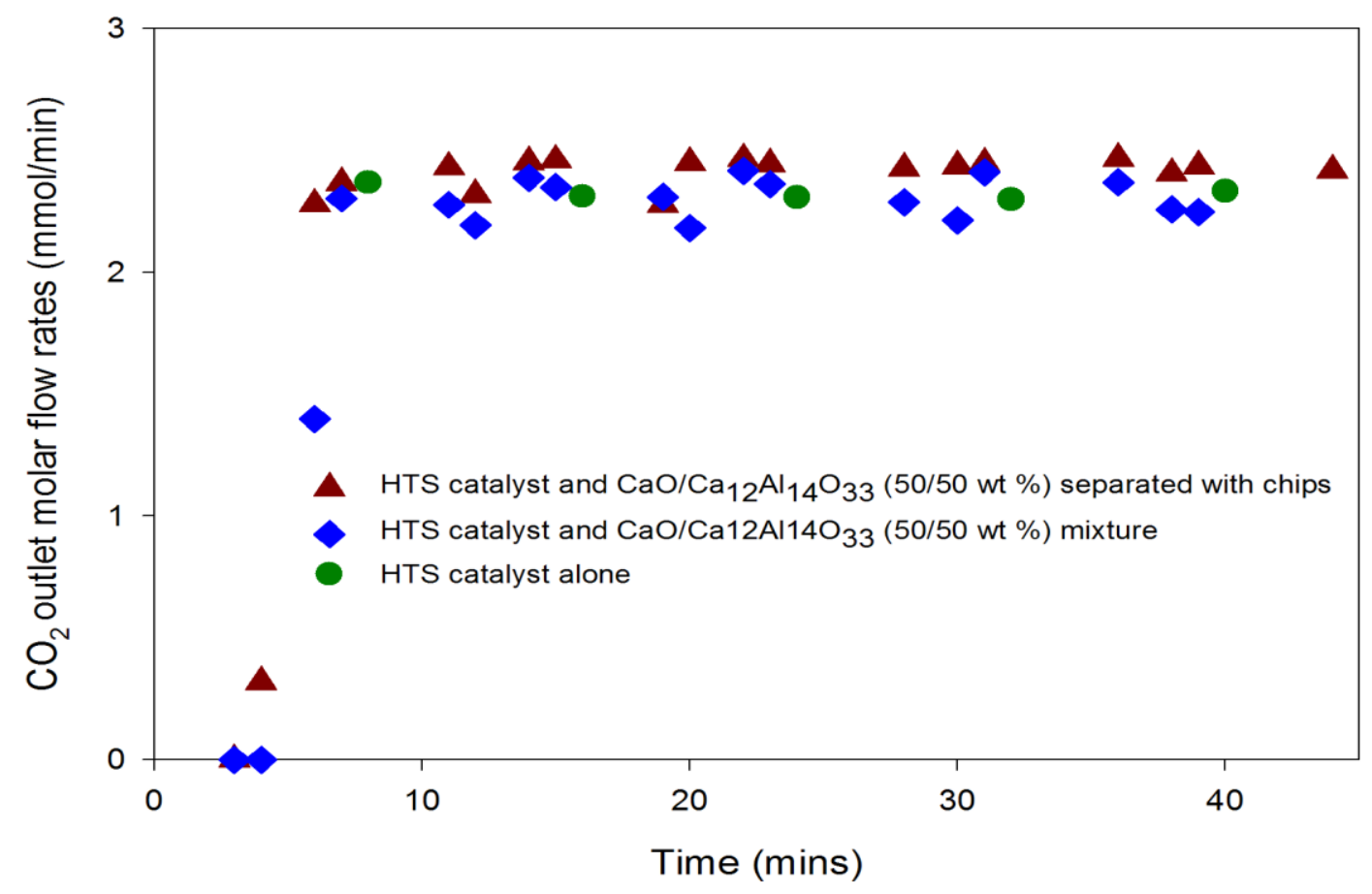

Figure 39. Profiles of $\mathrm{CO}_{2}$ for WGS reaction over $\mathrm{HTS}-\mathrm{CaO} / \mathrm{Ca}_{12} \mathrm{Al}_{14} \mathrm{O}_{33}(50 / 50 \mathrm{wt}$ $\%$ ) in both modes and $\mathrm{HTS}$ catalyst alone (T: $500{ }^{\circ} \mathrm{C}$, total flow: $380 \mathrm{sccm}, \mathrm{H}_{2} \mathrm{O} / \mathrm{CO}$ : 2). 


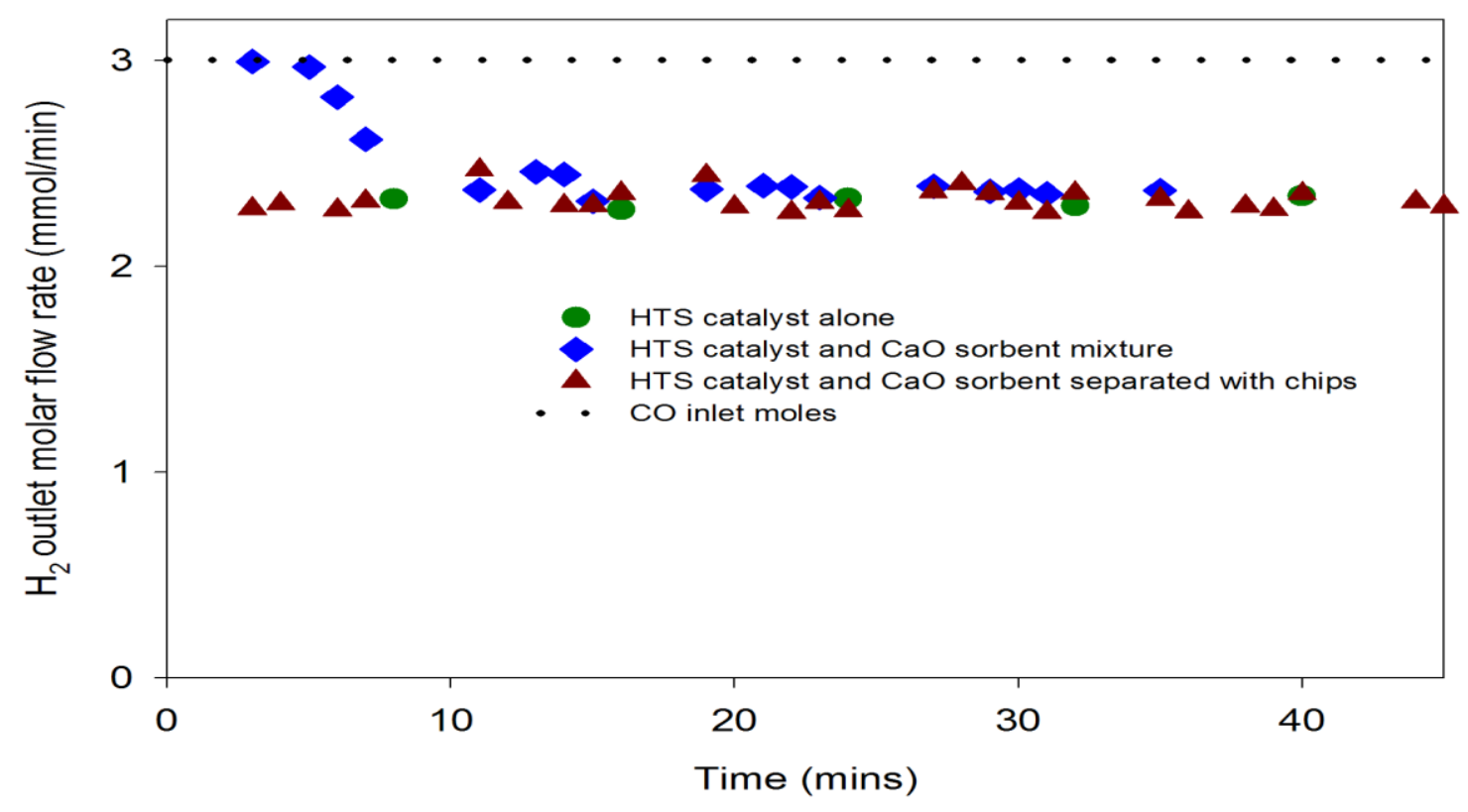

Figure 40. Profiles of $\mathrm{H}_{2}$ for WGS reaction over $\mathrm{HTS}-\mathrm{CaO}$ in both modes and $\mathrm{HTS}$ catalyst alone ( $\mathrm{T}: 500^{\circ} \mathrm{C}$, total flow: $380 \mathrm{sccm}, \mathrm{H}_{2} \mathrm{O} / \mathrm{CO}: 2$ )

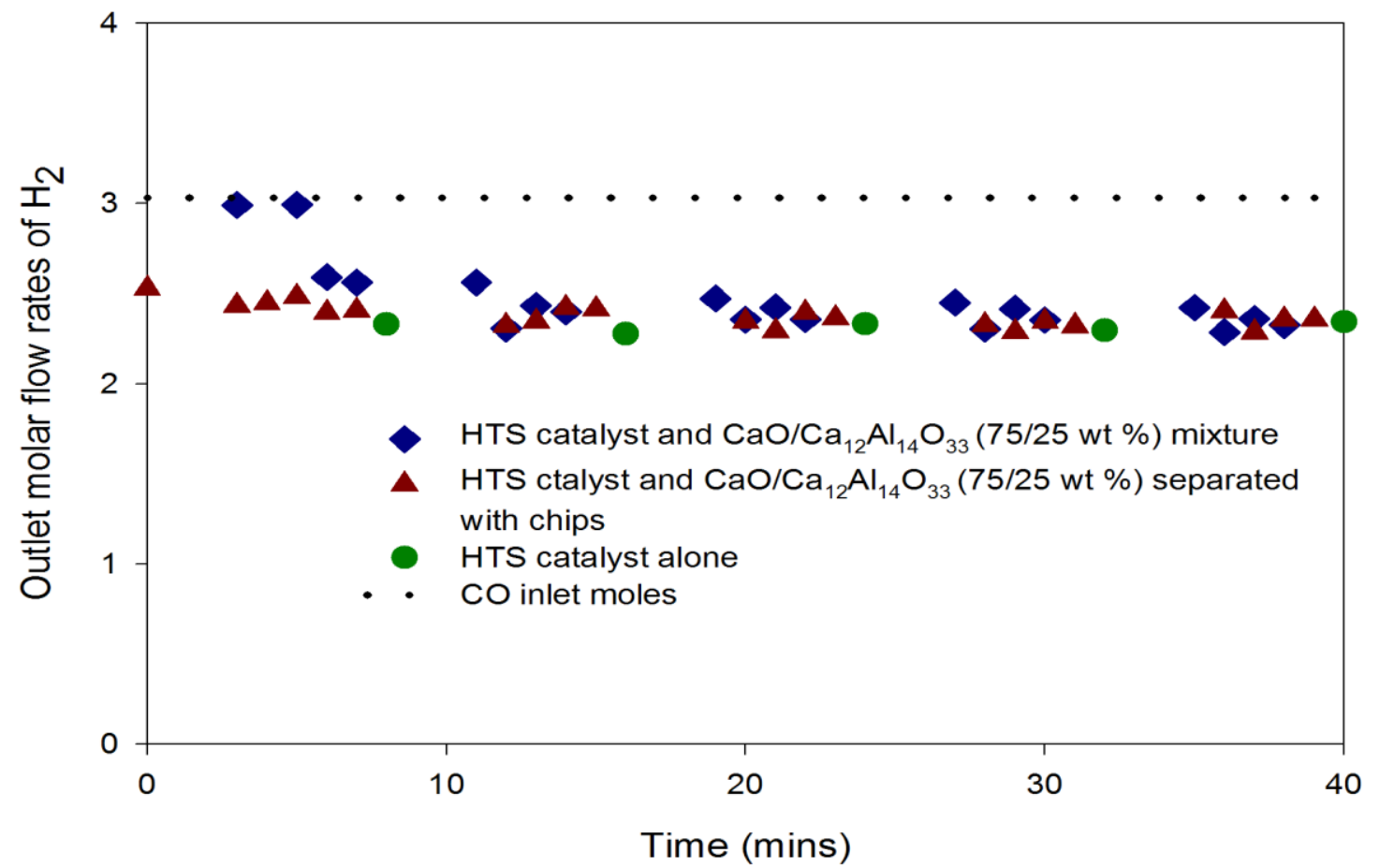

Figure 41. Profiles of $\mathrm{H}_{2}$ for WGS reaction over $\mathrm{HTS}-\mathrm{CaO} / \mathrm{Ca}_{12} \mathrm{Al}_{14} \mathrm{O}_{33}(75 / 25)$ in both modes and $\mathrm{HTS}$ catalyst alone $\left(\mathrm{T}: 500{ }^{\circ} \mathrm{C}\right.$, total flow: $\left.380 \mathrm{sccm}, \mathrm{H}_{2} \mathrm{O} / \mathrm{CO}: 2\right)$ 


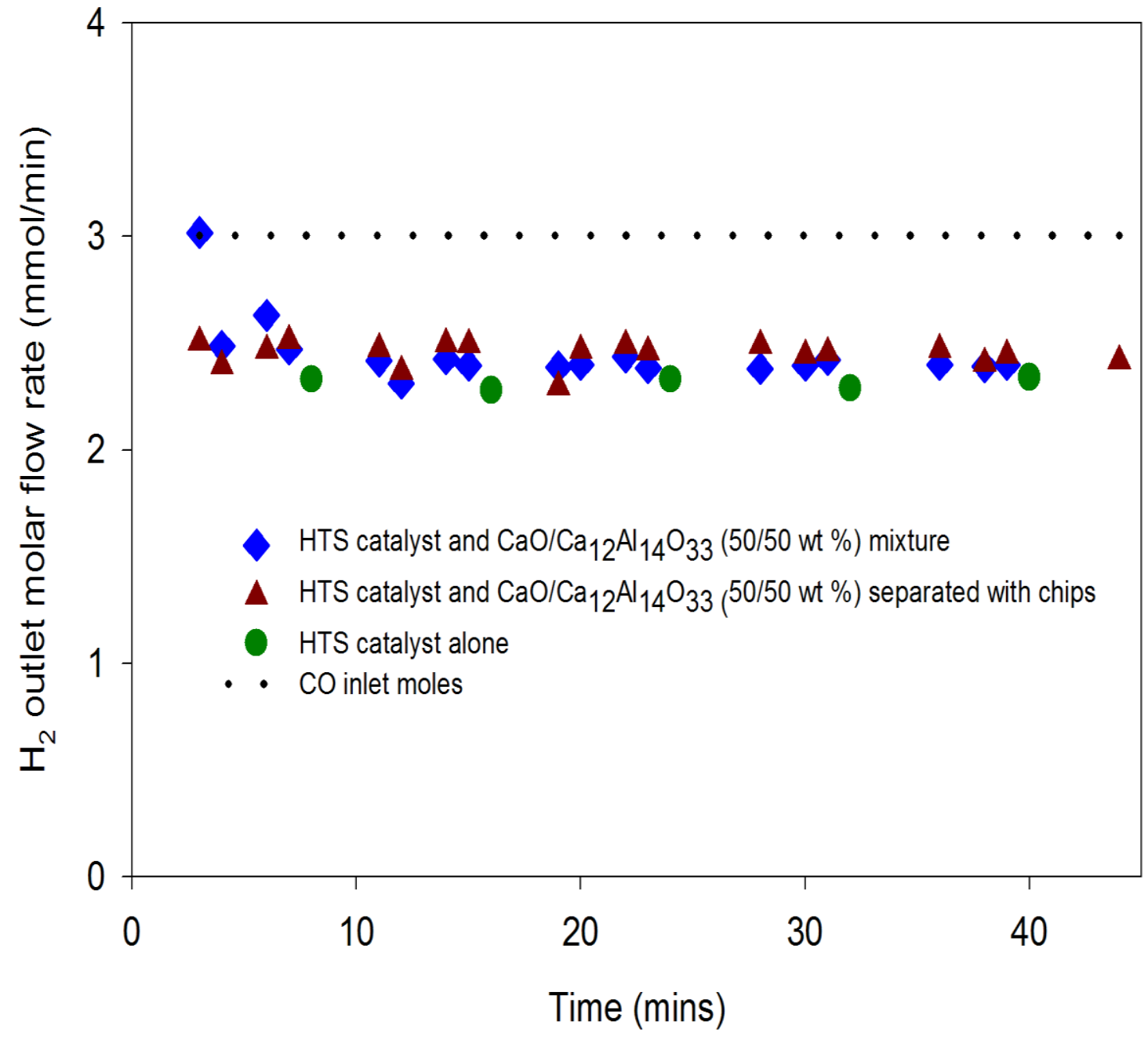

Figure 42. Profiles of $\mathrm{H}_{2}$ for WGS reaction over $\mathrm{HTS}-\mathrm{CaO} / \mathrm{Ca}_{12} \mathrm{Al}_{14} \mathrm{O}_{33}(50 / 50)$ in both modes and $\mathrm{HTS}$ catalyst alone $\left(\mathrm{T}: 500{ }^{\circ} \mathrm{C}\right.$, total flow: $\left.380 \mathrm{sccm}, \mathrm{H}_{2} \mathrm{O} / \mathrm{CO}: 2\right)$

\subsection{Comparison of adsorption capacity of different sorbents for combined WGS and carbonation reactions}

The $\mathrm{CO}_{2}$ capture capacity of sorbent is defined as:

$$
\text { Sorption capacity }=\frac{\text { Moles or grams of } \mathrm{CO}_{2} \text { adsorbed }}{1000 \text { grams of sorbent }}
$$


The $\mathrm{CO}_{2}$ capture capacities were determined from the results for both modes, SEWGS and separated beds, conducted at $500{ }^{\circ} \mathrm{C}$ with an operating pressure of 1 atm. The calculation procedure is given in Appendix I. The amount of $\mathrm{CO}_{2}$ captured by the sorbents can be correlated with the time of $\mathrm{CO}_{2}$ breakthrough and conversion of $\mathrm{CO}$ during the WGS reaction.

The $\mathrm{CO}_{2}$ capture capacity of each sorbent studied is summarized in Table 14. The capacity is given based on the total sorbent weight and on a $\mathrm{CaO}$ basis. The breakthrough times are also noted. Among the three sorbents, the $\mathrm{CaO}$ sorbent has the largest $\mathrm{CO}_{2}$ capacity, and $\mathrm{CaO} / \mathrm{Ca}_{12} \mathrm{Al}_{14} \mathrm{O}_{33}(50 / 50 \mathrm{wt} \%)$ has the smallest $\mathrm{CO}_{2}$ capacity value, based on the total weight of the sorbent. This is because the pure $\mathrm{CaO}$ sorbent has the largest amount of $\mathrm{CaO}$. As the quantity of $\mathrm{Ca}_{12} \mathrm{Al}_{14} \mathrm{O}_{33}$ increases in the sorbent, the $\mathrm{CO}_{2}$ sorption capacity of the sorbent decreases, as shown in Table 14. Also, all the three sorbents have approximately same $\mathrm{CO}_{2}$ capture capacity in both modes based on $\mathrm{CaO}$ weight. From the results, it can be shown that the $\mathrm{Ca}_{12} \mathrm{Al}_{14} \mathrm{O}_{33}$ in the sorbent acts only as a binder and does not take part in the carbonation reaction as discussed in Section.2.6.3.

In the separated mode, the $\mathrm{CaO}, \mathrm{CaO} / \mathrm{Ca}_{12} \mathrm{Al}_{14} \mathrm{O}_{33} \quad(75 / 25)$, and $\mathrm{CaO} / \mathrm{Ca}_{12} \mathrm{Al}_{14} \mathrm{O}_{33}(50 / 50)$ adsorb all the $\mathrm{CO}_{2}$ formed for the first 7,6 , and 3 mins respectively, and finally reach their post-breakthrough period at approximately 45 , 36 , and 28 mins respectively. The corresponding $\mathrm{CO}_{2}$ capture values are $8.27,6.36$, and $3.92 \mathrm{~mol} / \mathrm{Kg}$ respectively. In the combined mode (SEWGS), the sorbentenhancement period for $\mathrm{CaO}, \mathrm{CaO} / \mathrm{Ca}_{12} \mathrm{Al}_{14} \mathrm{O}_{33}$ (75/25), and $\mathrm{CaO} / \mathrm{Ca}_{12} \mathrm{Al}_{14} \mathrm{O}_{33}$ $(50 / 50)$ last for 6,5 , and 4 mins respectively. The sorbents $\mathrm{CaO}, \mathrm{CaO} / \mathrm{Ca}_{12} \mathrm{Al}_{14} \mathrm{O}_{33}$ 
(75/25), and $\mathrm{CaO} / \mathrm{Ca}_{12} \mathrm{Al}_{14} \mathrm{O}_{33}$ (50/50) reach their post-breakthrough at approximately 35, 29, and 20 mins respectively. The corresponding capture capacity values are $8.54,6.36$, and $4.16 \mathrm{~mol} / \mathrm{Kg}$ respectively.

The comparison of $\mathrm{CO}_{2}$ capture capacities obtained in the present study with data in the literature is given in Table 15 . The $\mathrm{CO}_{2}$ capture capacities of sorbents obtained in the present study work fall in the range of values obtained in the literature. However, the $\mathrm{CO}_{2}$ capture capacities of sorbents reported in the literature vary widely. This wide range may be attributed to the different operating conditions, equipments, and precursors.

The $\mathrm{CO}_{2}$ sorption capacities with respect to time for three sorbents in the two different modes are given in Figures 43-45. From all three figures, the sorbents mixed with catalyst adsorb slightly more $\mathrm{CO}_{2}$ than the sorbents kept apart from the catalyst. This increase may be because of the production of more moles of $\mathrm{CO}_{2}$ in the former case. The capacities for the $75 / 25$ and 50/50 mixtures are compared in Figure 46. The pre-breakthrough adsorption is the same. At larger times, the adsorption is greater for the $75 / 25$ mixture.

Finally, note that the SEWGS reaction over multiple cycles with $\mathrm{CaO}$ and $\mathrm{CaO} / \mathrm{Ca}_{12} \mathrm{Al}_{14} \mathrm{O}_{33}$ sorbents is required to find the best sorbent among them. Since the $\mathrm{CaO}$ particles are vulnerable to high calcination temperatures $\left(900-1000^{\circ} \mathrm{C}\right)$, the $\mathrm{CO}_{2}$ capture capacity of the $\mathrm{CaO}$ particles over multiple carbonation and calcination cycles decreases. On the other hand, the uniform distribution of $\mathrm{Ca}_{12} \mathrm{Al}_{14} \mathrm{O}_{33}$ among $\mathrm{CaO}$ particles provides a stable framework inhibiting the sintering of $\mathrm{CaO}$ during the calcination. ${ }^{68}$ 
Table 14. Capacity (weight basis and $\mathrm{CaO}$ basis), pre-breakthrough time, and post-breakthrough time for sorbents

\begin{tabular}{|c|c|c|c|c|c|c|}
\hline sorbent & \multicolumn{2}{|c|}{$\mathrm{CaO}$} & \multicolumn{2}{c|}{$\mathrm{CaO} / \mathrm{Ca}_{12} \mathrm{Al}_{14} \mathrm{O}_{33}(75 / 25)$} & \multicolumn{2}{c|}{${\mathrm{CaO} / \mathrm{Ca}_{12} \mathrm{Al}_{14} \mathrm{O}_{33}(50 / 50)}^{2}$} \\
\hline combination & $\begin{array}{c}\text { mixed with } \\
\text { HTS }\end{array}$ & $\begin{array}{c}\text { separated } \\
\text { beds }\end{array}$ & mixed with $\mathrm{HTS}$ & $\begin{array}{c}\text { separated } \\
\text { beds }\end{array}$ & mixed with HTS & $\begin{array}{c}\text { separated } \\
\text { beds }\end{array}$ \\
\hline $\begin{array}{c}\text { total weight basis } \\
\text { (mol/Kg) }\end{array}$ & 8.54 & 8.27 & 6.36 & 6.33 & 4.16 & 3.92 \\
\hline $\begin{array}{c}\text { CaO basis } \\
\text { (mol/Kg CaO) }\end{array}$ & 8.54 & 8.27 & 8.48 & 8.43 & 8.31 & 7.84 \\
\hline $\begin{array}{c}\text { Pre-breakthrough } \\
\text { time (mins) }\end{array}$ & 6 & 7 & 5 & 6 & 4 & 3 \\
\hline $\begin{array}{c}\text { Post-breakthrough } \\
\text { time (mins) }\end{array}$ & 35 & 45 & 29 & 36 & 20 & 28 \\
\hline
\end{tabular}


Table 15. Comparison with literature values

\begin{tabular}{|c|c|c|c|c|c|}
\hline \multirow{2}{*}{ Sorbent } & \multicolumn{2}{c|}{$\begin{array}{c}\text { Sorption capacity } \\
(\mathrm{mol} / \mathrm{Kg})\end{array}$} & \multicolumn{2}{c|}{$\begin{array}{c}\text { Theoretical sorption capacity } \\
\text { (mol/Kg) }\end{array}$} \\
\cline { 2 - 5 } & weight basis & CaO basis & weight basis & CaO basis & \\
\hline $\mathrm{CaO}$ (Alfa Aesar) & \multicolumn{2}{|c|}{$8.27-8.54$} & 17.863 & 17.863 & \multirow{2}{*}{ current work } \\
\hline $\mathrm{PCC}-\mathrm{CaO}$ (Section 2.7.1) & \multicolumn{2}{|c|}{$8.18-10.295$} & 17.863 & 17.863 & \multirow{2}{*}{10} \\
\hline $\mathrm{Linwood}(\mathrm{LC})-\mathrm{CaO}$ & \multicolumn{2}{|c|}{5.0} & 17.863 & 17.863 & \multirow{2}{*}{10} \\
\hline $\mathrm{CaO}$ & \multicolumn{2}{|c|}{6.25} & 17.863 & 17.863 & \multirow{2}{*}{62} \\
\hline $\mathrm{CaO}(10 \mu \mathrm{m})$ & \multicolumn{2}{|c|}{1.795} & 17.863 & 17.863 & 63 \\
\hline $\mathrm{CaO}(10 \mathrm{~nm})$ & \multicolumn{2}{|c|}{16.590} & 17.863 & 17.863 & 64 \\
\hline $\mathrm{CaO} / \mathrm{Ca}_{12} \mathrm{Al}_{14} \mathrm{O}_{33}(75 / 25)$ & $6.33-6.36$ & $8.43-8.48$ & 13.386 & 17.863 & \multirow{2}{*}{ current work } \\
\hline $\mathrm{CaO} / \mathrm{Ca}_{12} \mathrm{Al}_{14} \mathrm{O}_{33}(75 / 25)$ & 9.545 & 12.72 & 13.386 & 17.863 & 65 \\
\hline $\mathrm{CaO} / \mathrm{Ca}_{12} \mathrm{Al}_{14} \mathrm{O}_{33}(75 / 25)$ & 10.227 & 13.63 & 13.386 & 17.863 & 67 \\
\hline $\mathrm{CaO} / \mathrm{Ca}_{12} \mathrm{Al}_{14} \mathrm{O}_{33}(75 / 25)$ & 8.1318 & 10.843 & 13.386 & 17.863 & 66 \\
\hline $\mathrm{CaO} / \mathrm{Ca}_{12} \mathrm{Al}_{14} \mathrm{O}_{33}(75 / 25)$ & 7.4 & 9.8 & 13.386 & 17.863 & 68 \\
\hline $\mathrm{CaO} / \mathrm{Ca}_{12} \mathrm{Al}_{14} \mathrm{O}_{33}(65 / 35)$ & 5 & 7.69 & 11.60 & 17.863 & 68 \\
\hline $\mathrm{CaO} / \mathrm{Ca}_{12} \mathrm{Al}_{14} \mathrm{O}_{33}(50 / 50)$ & $3.92-4.15$ & $7.842-8.317$ & 8.931 & 17.863 & current work \\
\hline
\end{tabular}




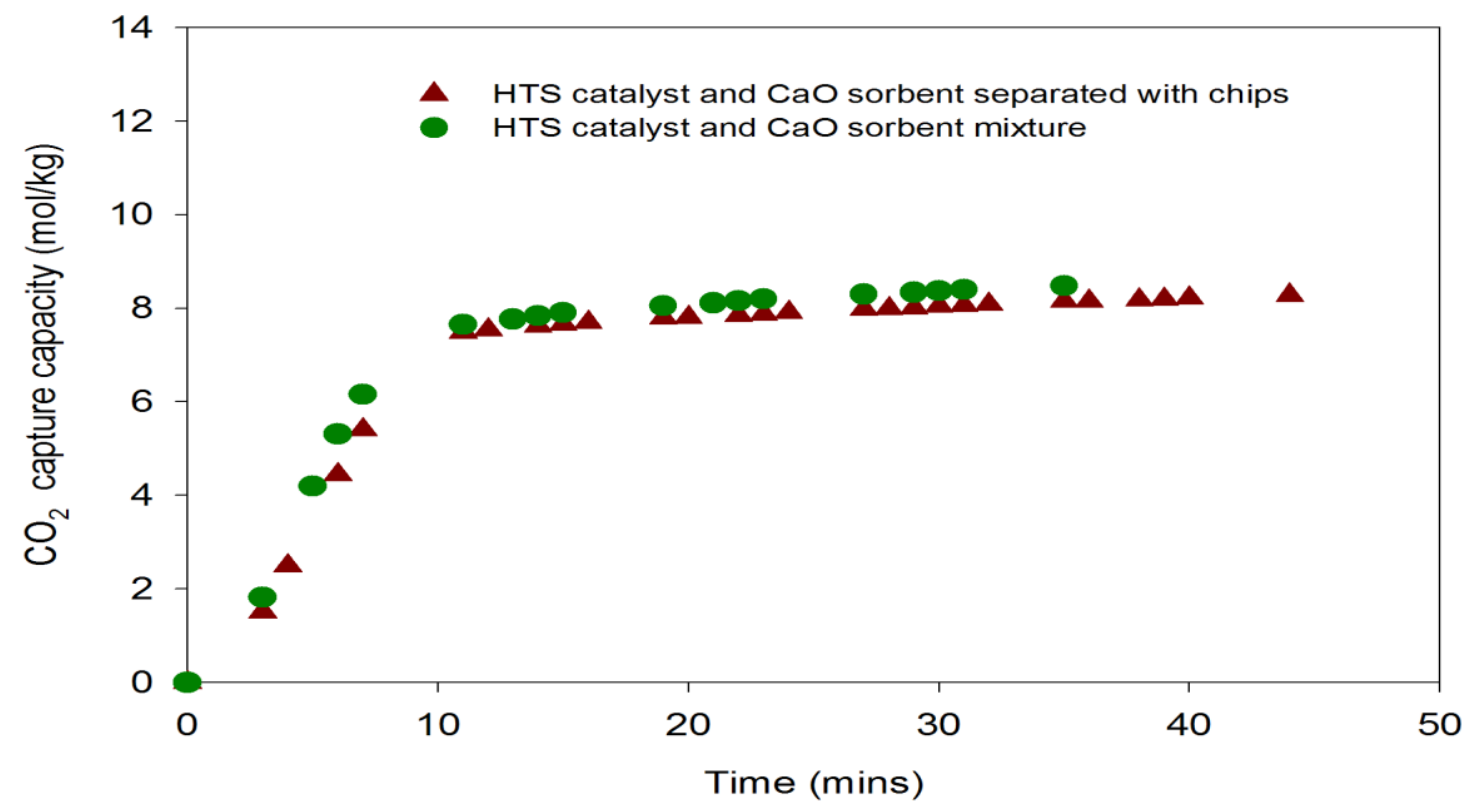

Figure 43. Adsorption capacity of $\mathrm{CaO}$ sorbent with respect to time in different modes

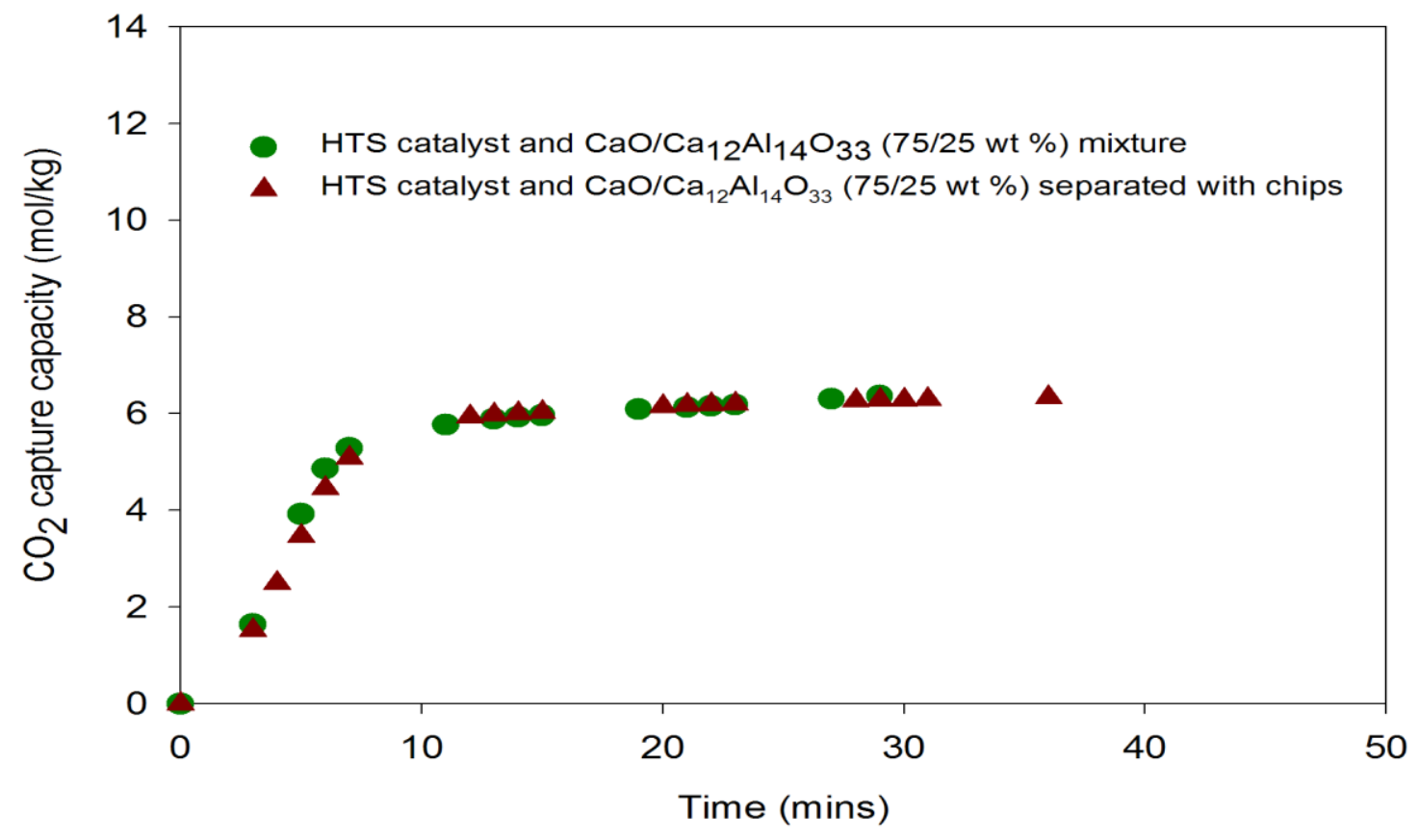

Figure 44. Adsorption capacity of $\mathrm{CaO} / \mathrm{Ca}_{12} \mathrm{Al}_{14} \mathrm{O}_{33}$ (75/25 wt \%) sorbent with respect to time in different modes 


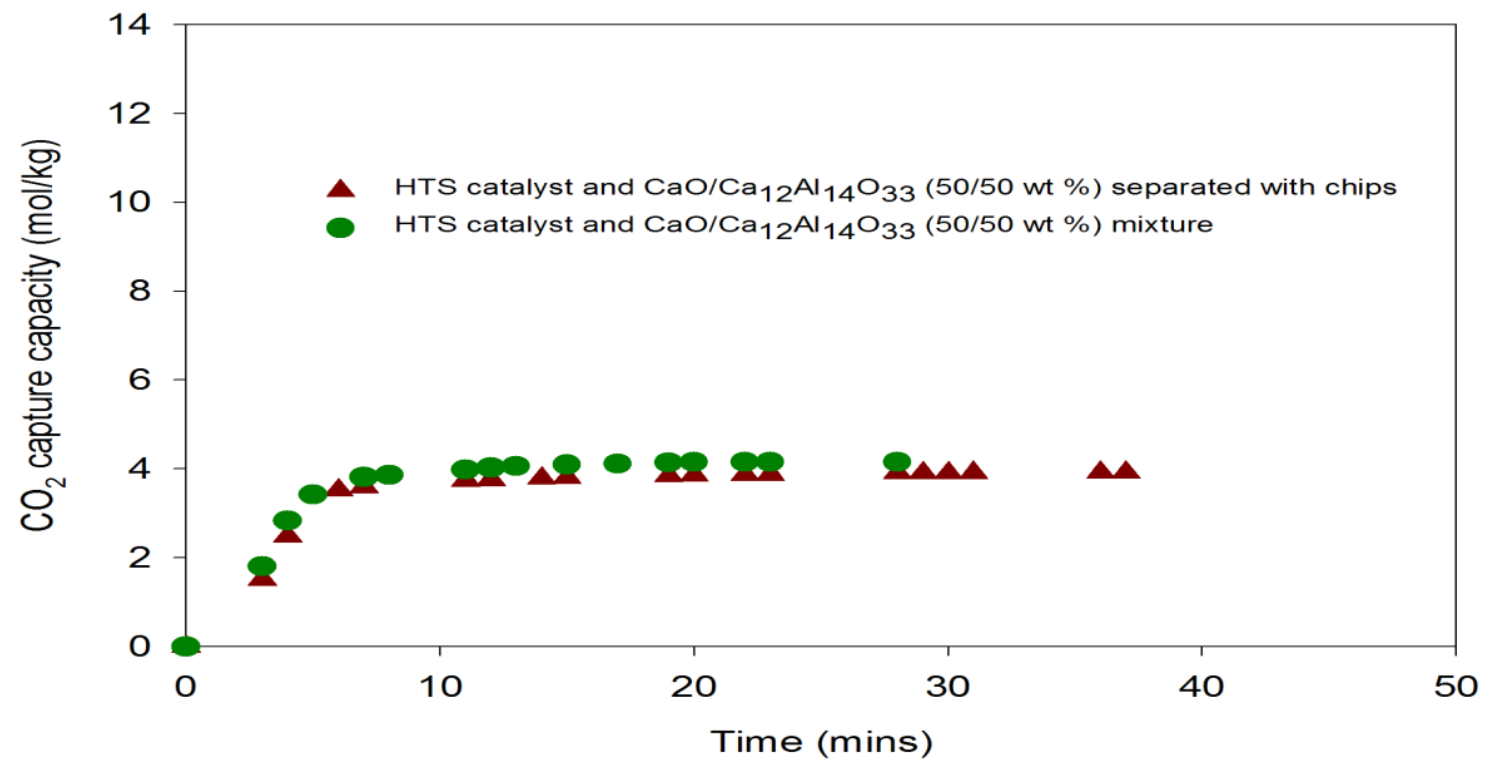

Figure 45. Adsorption capacity of sorbent $\mathrm{CaO} / \mathrm{Ca}_{12} \mathrm{Al}_{14} \mathrm{O}_{33}(50 / 50$ wt \%) with respect to time in different modes.

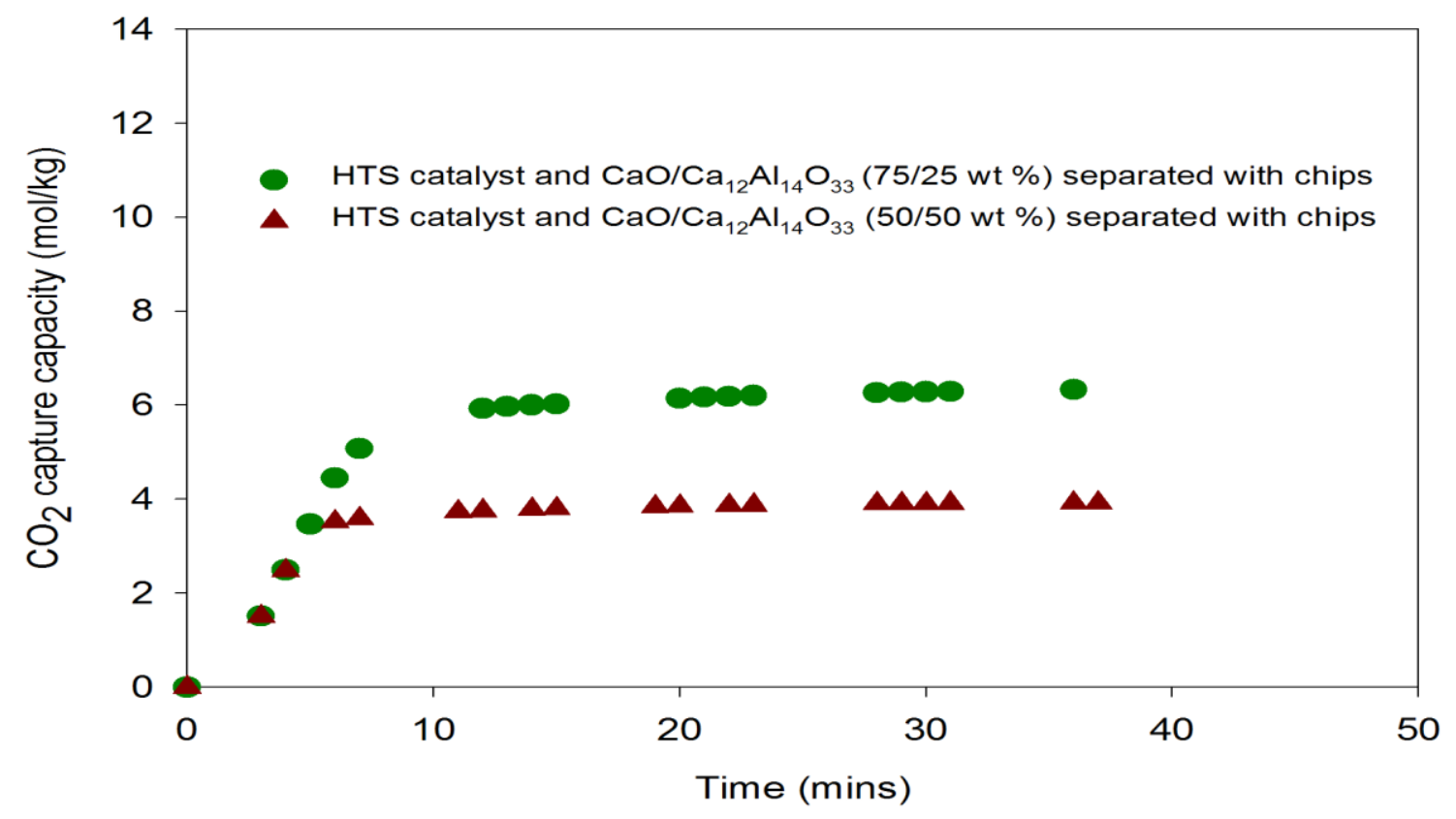

Figure 46. Adsorption capacity of sorbent $\mathrm{CaO} / \mathrm{Ca}_{12} \mathrm{Al}_{14} \mathrm{O}_{33}$ with respect to time in various ratios. 


\section{CHAPTER 5 SUMMARY AND FUTURE WORK}

\subsection{Summary}

Based on the various experiments performed for WGS reaction alone and combined WGS and carbonation reactions in the fixed-bed reactor, the following conclusions can be drawn:

1. The commercial HTS catalyst used in the present study was characterized using BET, XRD, and SEM/EDS. The surface area and pore volume of the HTS catalyst are found to be $193.0 \mathrm{~m}^{2} / \mathrm{g}$ and $0.21 \mathrm{ml} / \mathrm{g}$ respectively. The SEM/EDS results show that the HTS catalyst is highly porous, with a grainlike structure, and contains iron, chromium, oxygen, and carbon. The XRD patterns of the HTS catalyst confirm the presence of $\mathrm{Fe}_{2} \mathrm{O}_{3}$. However, $\mathrm{Cr}_{2} \mathrm{O}_{3}$ and $\mathrm{CuO}$ crystalline phases are not prominent in the XRD pattern. Perhaps the $\mathrm{Cu}$ and $\mathrm{Cr}$ exist in solid solution within the hematite lattice. The $\mathrm{CaO} / \mathrm{Ca}_{12} \mathrm{Al}_{14} \mathrm{O}_{33}$ sorbent was synthesized in a $75 / 25$ ratio following the literature. A 50/50 mixture was synthesized following an analogous procedure. The XRD patterns of the synthesized $\mathrm{CaO} / \mathrm{Ca}_{12} \mathrm{Al}_{14} \mathrm{O}_{33}$ sorbent, both 75/25 and 50/50, confirm the phases of $\mathrm{CaO}$ and mayenite $\left(\mathrm{Ca}_{12} \mathrm{Al}_{14} \mathrm{O}_{33}\right)$. No other phases are found.

2. Blank tests were conducted to study the activity of WGS reaction in the absence of the catalyst or sorbent over a temperature range of $450-600{ }^{\circ} \mathrm{C}$. A total flow of $200 \mathrm{sccm}$ with $\mathrm{H}_{2} \mathrm{O} / \mathrm{CO}$ ratio of 2 was used. There is negligible activity of the WGS reaction between $450-500{ }^{\circ} \mathrm{C}$ and almost no products are 
detected. However, between $550-600^{\circ} \mathrm{C}$, carbon monoxide conversion and hydrogen flow rates are measurable but small, and of the order of GC measurement error.

3. The WGS reaction was performed using the commercial HTS catalyst $\left(\mathrm{Fe}_{2} \mathrm{O}_{3} / \mathrm{Cr}_{2} \mathrm{O}_{3} / \mathrm{CuO}\right)$ alone. The effect of temperature and $\mathrm{H}_{2} \mathrm{O} / \mathrm{CO}$ ratio on WGS reaction was examined. The CO conversion increases with temperature from $350{ }^{\circ} \mathrm{C}$ to $500^{\circ} \mathrm{C}$ and thereafter it is approximately constant. It is due to the thermodynamic limitations imposed on the WGS reaction. Also, the CO conversion increases with $\mathrm{H}_{2} \mathrm{O} / \mathrm{CO}$ ratio. In all the cases, the reaction system was operated in the region below the thermodynamic equilibrium. The forward and reverse kinetic parameters, $k_{f}$ and $k_{r}$, of the WGS reaction were determined at different temperatures. The activation energy $\left(E_{a}\right)$ and preexponential factor $\left(k_{0}\right)$ of WGS reaction over HTS catalyst were found to be $79.01 \mathrm{KJ} / \mathrm{mol}$ and $2.44 \times 10^{3} \mathrm{~mol} / \mathrm{gcatalyst} / \mathrm{sec} / \mathrm{atm}^{2}$ respectively. The values obtained are consistent with reported data in the literature.

4. The $\mathrm{CaO}$ does not show any activity towards WGS reaction. The activity of the sorbent $\mathrm{CaO} / \mathrm{Ca}_{12} \mathrm{Al}_{14} \mathrm{O}_{33}$ (both $75 / 25 \mathrm{wt} \%$ and $50 / 50$ wt \%) towards WGS reaction is very small. The CO conversion and hydrogen flow rates are measurable but small, and of the order of GC measurement error.

5. The combined WGS and carbonation reactions were conducted. Conditions are $500{ }^{\circ} \mathrm{C}$ and 1 atm with a $\mathrm{H}_{2} \mathrm{O} / \mathrm{CO}$ ratio of 2 . Two different modes were used: catalyst and sorbent well mixed (sorption-enhanced WGS, SEWGS), and catalyst and sorbent separated by quartz chips. 
6. The SEWGS reaction proceeds in three phases: sorbent-enhancement, sorbent- breakthrough, and post-breakthrough. During the sorbentenhancement period, the CO conversion obtained is very high and the amount of $\mathrm{H}_{2}$ produced is at its maximum. For the $\mathrm{HTS}-\mathrm{CaO}$ system, no $\mathrm{CO}_{2}$ is detected in the reactor outlet till after the $6^{\text {th }}$ minute. This period is the sorbent-enhancement period for HTS-CaO system. For the HTS$\mathrm{CaO} / \mathrm{Ca}_{12} \mathrm{Al}_{14} \mathrm{O}_{33}(75 / 25)$ system, the sorbent enhancement period lasts for 5 minutes. For the $\mathrm{HTS}-\mathrm{CaO} / \mathrm{Ca}_{12} \mathrm{Al}_{14} \mathrm{O}_{33}(50 / 50 \mathrm{wt} \%)$, this period lasts for only 4 minutes. The $\mathrm{CO}_{2}$ is first observed in the reactor outlet for $\mathrm{CaO}$ and $\mathrm{CaO} / \mathrm{Ca}_{12} \mathrm{Al}_{14} \mathrm{O}_{33}\left(75 / 25\right.$ wt \%), and $\mathrm{CaO} / \mathrm{Ca}_{12} \mathrm{Al}_{14} \mathrm{O}_{33}(50 / 50$ wt \%) at 7,6 , and 5 minutes respectively. The sorbents $\mathrm{CaO}, \mathrm{CaO} / \mathrm{Ca}_{12} \mathrm{Al}_{14} \mathrm{O}_{33}(75 / 25)$, and $\mathrm{CaO} / \mathrm{Ca}_{12} \mathrm{Al}_{14} \mathrm{O}_{33} \quad(50 / 50)$ reach their post-breakthrough period at approximately 35,29 , and 20 minutes respectively. The activity of the catalyst-sorbent combinations towards SEWGS decreases in the order of $\mathrm{CaO}, \mathrm{CaO} / \mathrm{Ca}_{12} \mathrm{Al}_{14} \mathrm{O}_{33}$ (75/25 wt \%), and $\mathrm{CaO} / \mathrm{Ca}_{12} \mathrm{Al}_{14} \mathrm{O}_{33}$ (50/50 wt \%) sorbent. The $\mathrm{CaO}$ sorbent is found to show slightly better performance towards SEWGS reaction relative to $\mathrm{CaO} / \mathrm{Ca}_{12} \mathrm{Al}_{14} \mathrm{O}_{33}$ (75/25 wt \%).

7. To understand the role of the sorbents better, experiments were carried out with the catalyst and each sorbent present in the reactor, but separated by a layer of quartz chips. The presence of any sorbent $\left(\mathrm{CaO}, \mathrm{CaO} / \mathrm{Ca}_{12} \mathrm{Al}_{14} \mathrm{O}_{33}\right.$ whether $75 / 25$ wt $\%$ or $50 / 50$ wt \%) in the reactor as a separate bed does not affect the CO conversion. Hence, the values obtained are the same as that of HTS catalyst alone. The $\mathrm{CaO}, \mathrm{CaO} / \mathrm{Ca}_{12} \mathrm{Al}_{14} \mathrm{O}_{33}$ (75/25 wt \%), and 
$\mathrm{CaO} / \mathrm{Ca}_{12} \mathrm{Al}_{14} \mathrm{O}_{33}(50 / 50 \mathrm{wt} \%)$ adsorb all the $\mathrm{CO}_{2}$ formed for the first 7,6 , and 3 minutes respectively, and reach their post-breakthrough period at approximately 45,36 , and 28 minutes respectively.

8. The sorption capacities of $\mathrm{CaO}, \mathrm{CaO} / \mathrm{Ca}_{12} \mathrm{Al}_{14} \mathrm{O}_{33} \quad(75 / 25$ wt \%), and $\mathrm{CaO} / \mathrm{Ca}_{12} \mathrm{Al}_{14} \mathrm{O}_{33}$ (50/50 wt \%) were determined based both on the total weight of sorbent and on a $\mathrm{CaO}$ basis in the sorbent. On the total weight basis, the $\mathrm{CO}_{2}$ sorption capacities of $\mathrm{CaO}, \mathrm{CaO} / \mathrm{Ca}_{12} \mathrm{Al}_{14} \mathrm{O}_{33}(75 / 25$ wt \%), and $\mathrm{CaO} / \mathrm{Ca}_{12} \mathrm{Al}_{14} \mathrm{O}_{33}(50 / 50 \mathrm{wt} \%)$ sorbents in the separated mode are 8.28, 6.33 , and $3.92 \mathrm{~mol} / \mathrm{Kg}$ respectively. In the mixed mode, the corresponding capacities are $8.54,6.36$, and $4.16 \mathrm{~mol} / \mathrm{Kg}$ respectively. On the $\mathrm{CaO}$ basis, the $\mathrm{CO}_{2}$ capture capacities in the separated mode are 8.43 and $7.84 \mathrm{~mol} / \mathrm{Kg}$ respectively, while in the combined mode, the corresponding values are 8.48 and $8.31 \mathrm{~mol} / \mathrm{Kg}$ respectively. Hence, in the mixed (SEWGS) mode, the $\mathrm{CO}_{2}$, capture capacities of all the sorbents are found to be approximately the same on the $\mathrm{CaO}$ basis. From these results, it is observed that the calcium aluminate $\left(\mathrm{Ca}_{12} \mathrm{Al}_{14} \mathrm{O}_{33}\right)$ acts as binder and does not necessarily participate in the carbonation reaction. The $\mathrm{CO}_{2}$ capture capacities of $\mathrm{CaO}$ and $\mathrm{CaO} / \mathrm{Ca}_{12} \mathrm{Al}_{14} \mathrm{O}_{33}$ sorbents obtained in the present study fall in the range of values reported in the literature.

9. The SEWGS reaction over multiple cycles with $\mathrm{CaO}$ and $\mathrm{CaO} / \mathrm{Ca}_{12} \mathrm{Al}_{14} \mathrm{O}_{33}$ sorbents is required to find the best sorbent among them. Since the $\mathrm{CaO}$ particles are vulnerable to high calcination temperatures $\left(900-1000^{\circ} \mathrm{C}\right)$, the $\mathrm{CO}_{2}$ capture capacity of the $\mathrm{CaO}$ particles over multiple carbonation and 
calcination cycles decreases. On the other hand, the uniform distribution of $\mathrm{Ca}_{12} \mathrm{Al}_{14} \mathrm{O}_{33}$ among $\mathrm{CaO}$ particles provides a stable framework inhibiting the sintering of $\mathrm{CaO}$ during the calcination. ${ }^{68}$

\subsection{Future Work}

In the present study, the WGS reaction was studied over HTS catalyst at a specific space velocity and at atmospheric pressure. Future work could involve the study of the WGS reaction at different space velocities and pressure.

The type of catalyst used could also be changed. The $\mathrm{Cr}_{2} \mathrm{O}_{3}$ in the HTS catalyst creates some environmental problems. Therefore, the HTS catalysts can be prepared by replacing $\mathrm{Cr}_{2} \mathrm{O}_{3}$ with other oxides. Some examples of these catalysts are $\mathrm{Fe}_{2} \mathrm{O}_{3} / \mathrm{Al}_{2} \mathrm{O}_{3} / \mathrm{CuO}$ and $\mathrm{Fe}_{2} \mathrm{O}_{3} / \mathrm{MoO}_{3} / \mathrm{CuO}$. Also the effect of catalyst pore size on the activity of WGS reaction can be studied.

In the present study, for all the experiments, the product analysis was carried out with a GC. However, the GC provides product data at times approximately 10 minutes apart. In order to get the product data at shorter intervals (approximately 1 min), a series of experiments had to be done. On the other hand, a mass spectrometer can provide the product analysis almost continuously. Therefore, use of a mass spectrometer can be recommended for future work.

The sorption-enhanced water-gas shift reaction over multiple cycles with HTS catalyst-sorbent mixture can be studied. In these studies, catalyst and sorbent in various sizes can be used, in order to separate catalyst and sorbent from each other

once the sorbent is saturated. The sorbent can be calcined in various media, such 
as nitrogen, $\mathrm{H}_{2} \mathrm{O}$, and vacuum. The effect of calcination medium on capture capacity can be studied. Also the effect of various $\mathrm{H}_{2} \mathrm{O} / \mathrm{CO}$ ratios on the SEWGS reaction can be investigated.

The flue gas obtained from the gasifier typically contains impurities such as sulfur (in the form of $\mathrm{H}_{2} \mathrm{~S}$ ) which deactivate the catalyst and also result in the sulfidation reactions with the sorbents. Therefore, the effect of impurities on catalyst and sorbent can be investigated. 


\section{APPENDICES}




\section{APPENDIX A: Mass Flow Controller calibration curves}

The catalyst unit system has four lines for feed gases, each one independently controlled by a Brooks' mass-flow controller (MFC). The mass-flow controllers are enclosed in an insulated styrofoam container to minimize the effect of any change in room temperature on the calibration process. Initially, the gas flow rate for particular MFC is set to the maximum set value and the system is allowed to reach steady state. Then, the outlet flows for different set points on each mass-flow meter are measured using a bubble flow meter. The same procedure is repeated for the other mass-flow controllers. The procedure is repeated each time prior to each experiment at the reaction conditions. The calculations are as given below.

Volumetric flow rate of the gas as measured by bubble flow meter $=\mathrm{V}_{1} \mathrm{cc} / \mathrm{min}$

Ambient pressure $=P_{1}$ atm

Ambient temperature $=T_{1} \mathrm{~K}$

Assuming ideal gas law holds good for all the gases:

Volumetric flow rate of the gas at STP conditions are:

$V_{2}=\left(P_{1} / P_{2}\right)^{*}\left(T_{2} / T_{1}\right)^{*} V_{1} \mathrm{cc} / \mathrm{min}$

Where, $V_{1}$ is the volume of the gas " $n$ " in the loop at STP conditions, cc

$\mathrm{P}_{2}$ is the atmospheric pressure, $1 \mathrm{~atm}$

$\mathrm{T}_{2}$ is the temperature at STP conditions, $273 \mathrm{~K}$

Hence, the molar flow rate of the gas, $\mathrm{n}=\mathrm{V}_{2} / 22400(\mathrm{~mol} / \mathrm{min})$

The MFC calibration curves for $\mathrm{CO}, \mathrm{CO}_{2}, \mathrm{He}, \mathrm{Ar}$, and $\mathrm{H}_{2}$ are given below. 


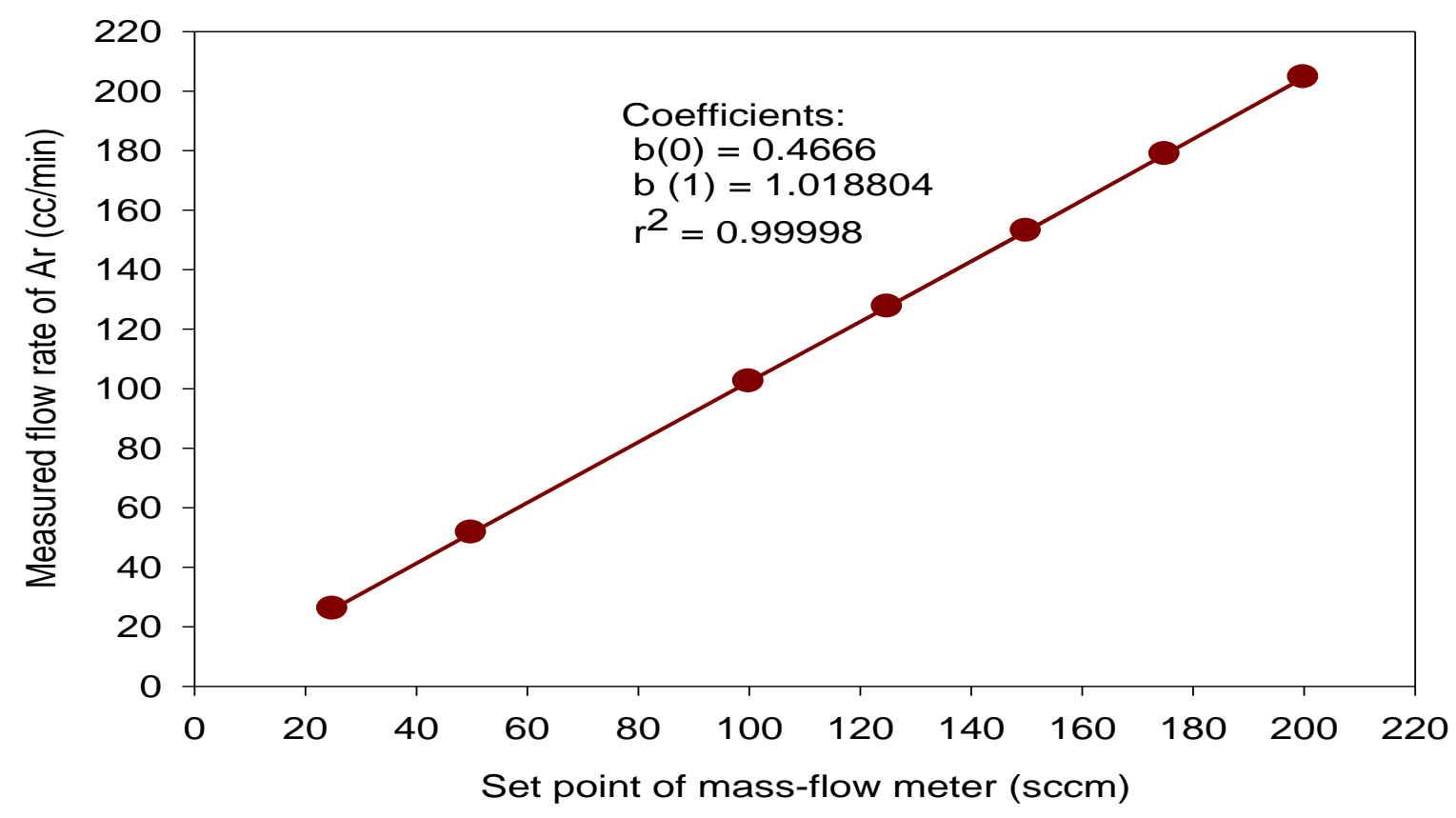

Figure 47. MFC Calibration curve for argon

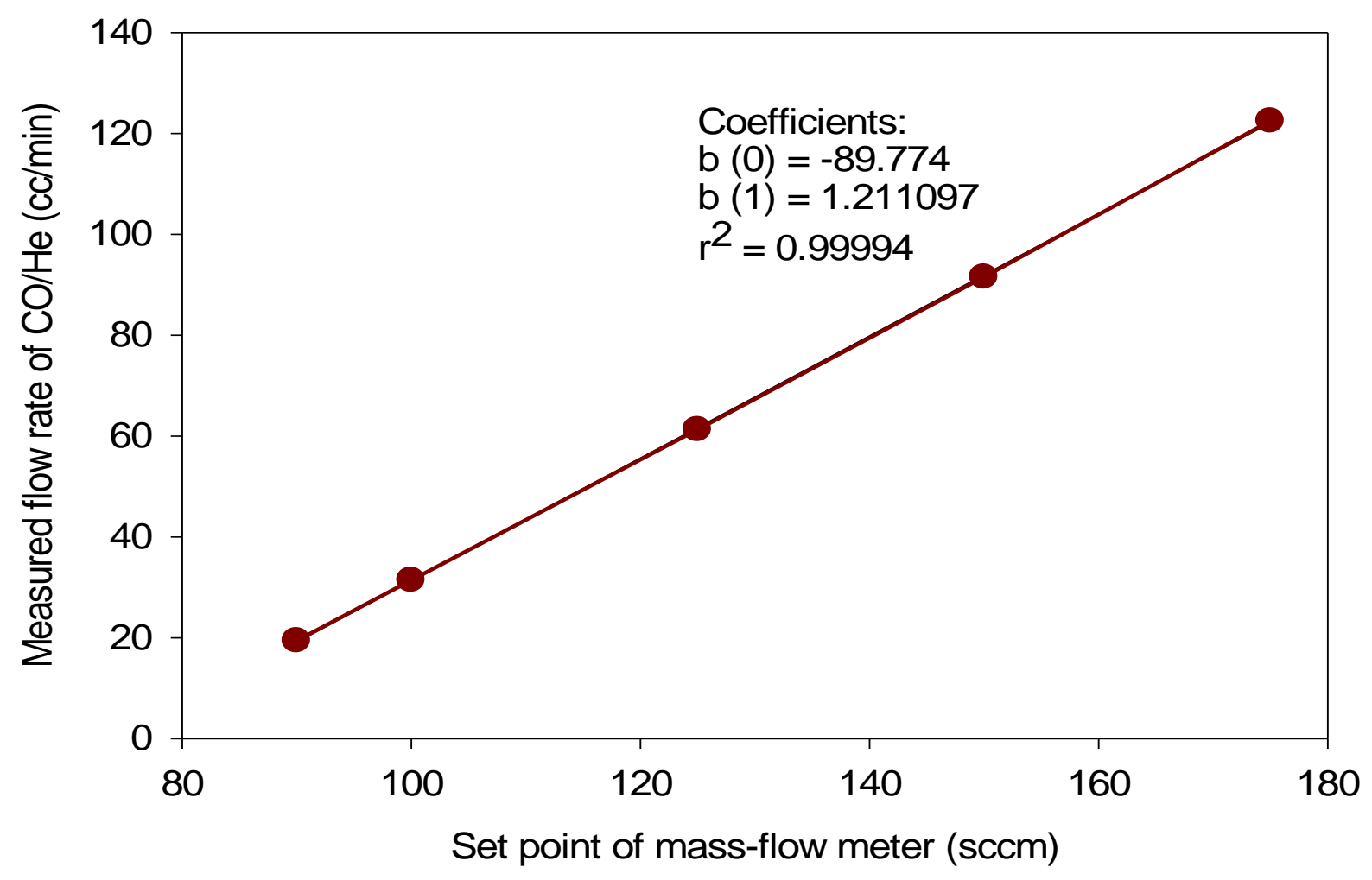

Figure 48. MFC calibration curve for $\mathrm{CO} / \mathrm{He}$ mixture 


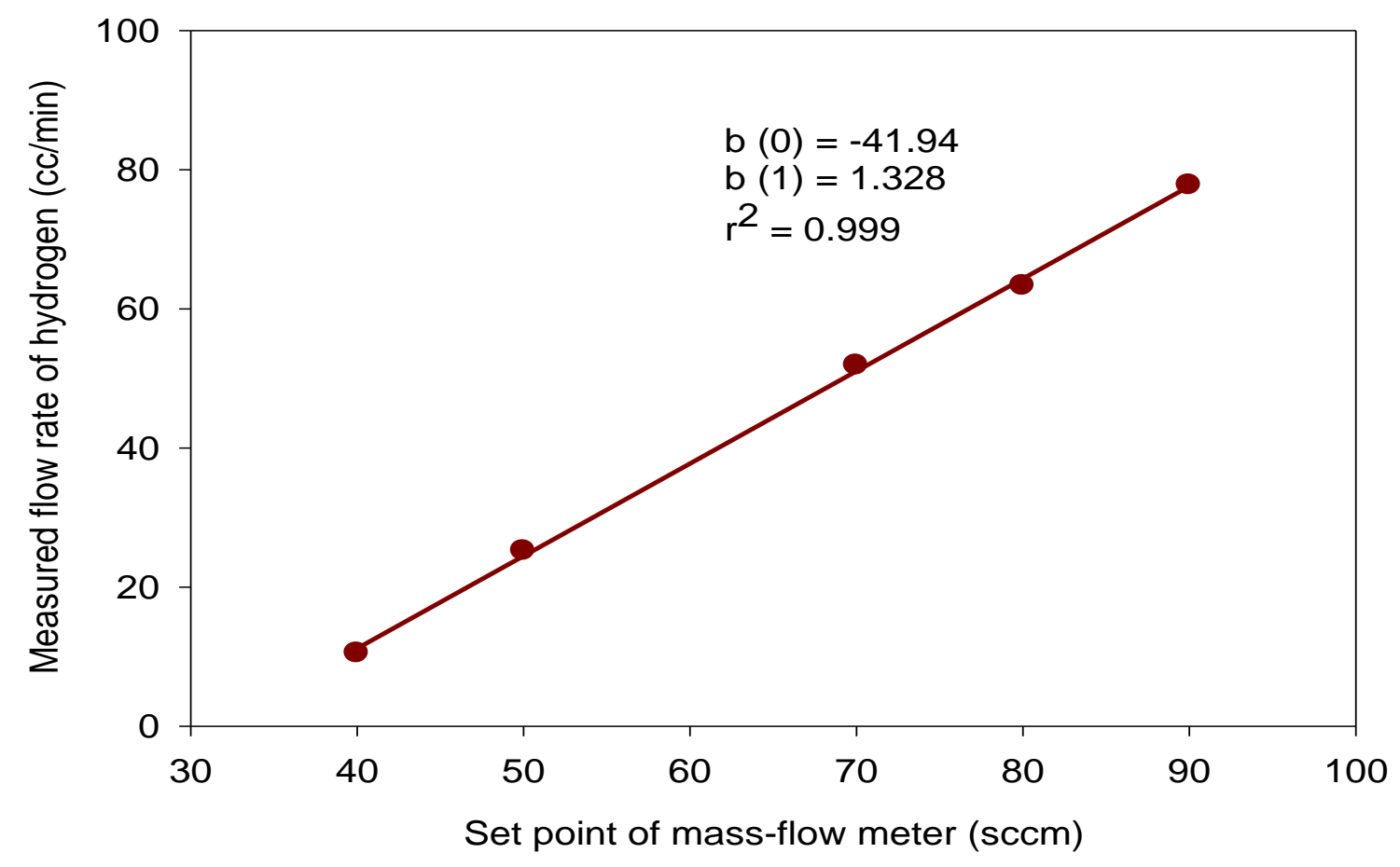

Figure 49. MFC calibration curve for hydrogen

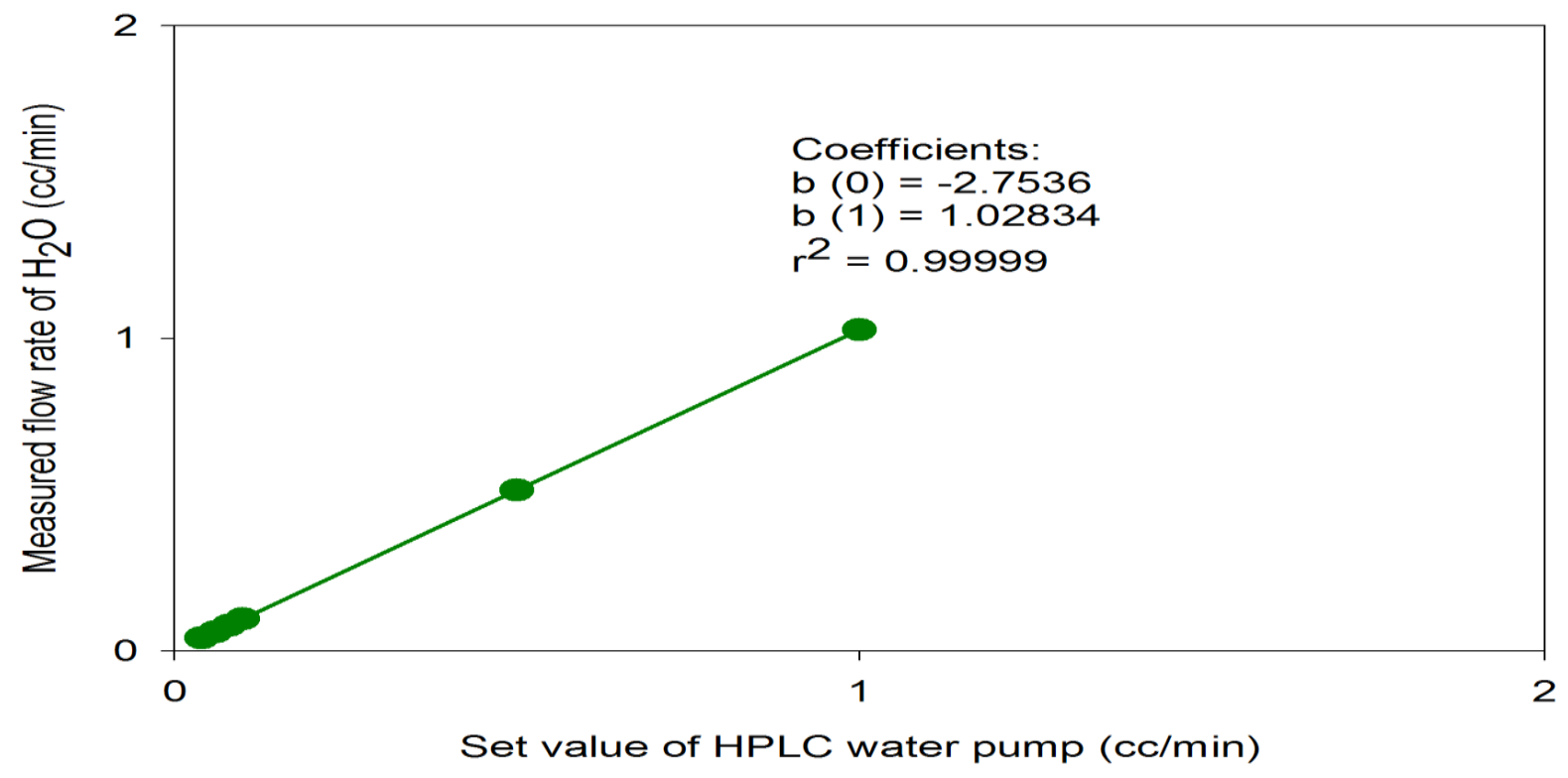

Figure 50. Calibration curve for HPLC pump 


\section{APPENDIX B: Gas Chromatograph operating conditions}

Gas chromatograph type: Hewlett-Packard 5890 II

Detector used: Thermal- conductivity detector (TCD)

Detector temperature: $255^{\circ} \mathrm{C}$

Carrier gas: Argon

Carrier gas inlet pressure: 70 Psig

Total carrier gas flow rate: $50.6 \mathrm{ml} / \mathrm{min}$

Reference flow rate: $35.1 \mathrm{ml} / \mathrm{min}$

Column flow rate: $15.5 \mathrm{ml} / \mathrm{min}$

Column used: HayeSep-D packed column

Oven temperature: $150^{\circ} \mathrm{C}$

Injector $\mathrm{A}$ temperature: $150{ }^{\circ} \mathrm{C}$

Period of analysis: 30 minutes, 60 minutes, 8 minutes

Chromatographs showing separation of different gases during WGS and SEWGS reaction at $500{ }^{\circ} \mathrm{C}$ are given in Figures 50 and 51 respectively. 


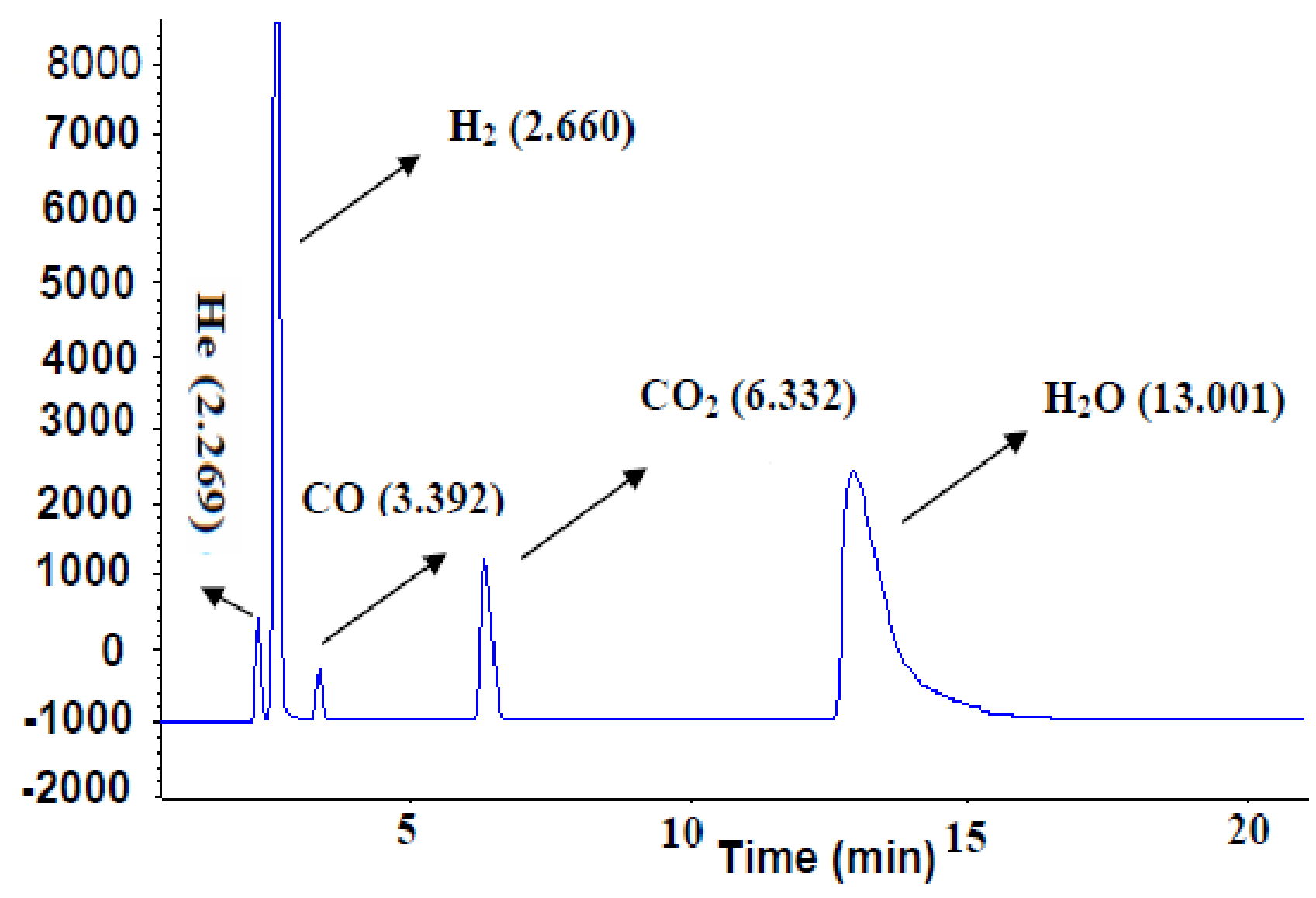

Figure 51. A schematic chromatogram showing separation of different gases during the WGS reaction at $500{ }^{\circ} \mathrm{C}$ Conditions: $\mathrm{T}: 500{ }^{\circ} \mathrm{C}$, Catalyst: $\mathrm{Fe}_{2} \mathrm{O}_{3} / \mathrm{Cr}_{2} \mathrm{O}_{3} / \mathrm{CuO}, \mathrm{H}_{2} \mathrm{O} / \mathrm{CO}: 2$, P: $1 \mathrm{~atm}$ 


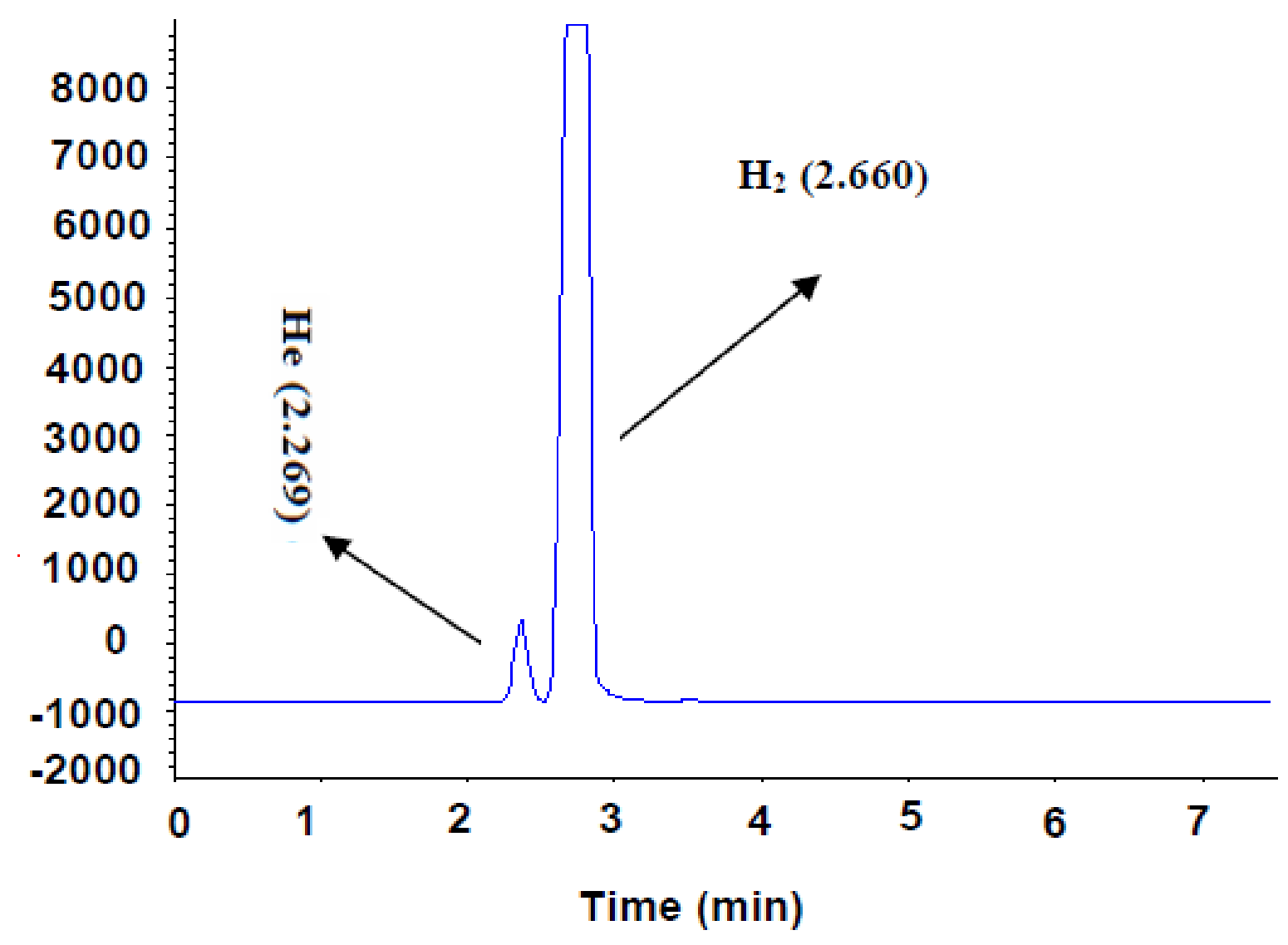

Figure 52. A schematic chromatogram showing separation of different gases during the SEWGS reaction at $500{ }^{\circ} \mathrm{C}$ Conditions: $\mathrm{T}: 500^{\circ} \mathrm{C}$, Catalyst: $\mathrm{Fe}_{2} \mathrm{O}_{3} / \mathrm{Cr}_{2} \mathrm{O}_{3} / \mathrm{CuO}$, sorbent: $\mathrm{CaO}, \mathrm{H}_{2} \mathrm{O} / \mathrm{CO}: 2$, P: $1 \mathrm{~atm}$ 


\section{APPENDIX C: GC Calibration curves}

For TCD calibration, 3 sets of standard gases are used and given below.

Set 1: $\mathrm{CH}_{4}$ mixture $+\mathrm{H}_{2}+\mathrm{Ar}$

Set 2: $\mathrm{CH}_{4}$ mixture + Steam $\left(\mathrm{H}_{2} \mathrm{O}\right)+\mathrm{Ar}$

Set 3: $\mathrm{CO} / \mathrm{He}+\mathrm{H}_{2}+\mathrm{Ar}$

The $\mathrm{CH}_{4}$ mixture will contain $\mathrm{He}, \mathrm{CH}_{4}, \mathrm{CO}_{2}$, and $\mathrm{Ar}$ with a ratio of 4:30:30:36 and the ratio of $\mathrm{CO}$ to $\mathrm{He}$ in $\mathrm{CO} / \mathrm{He}$ mixture is $5.25: 94.75$. A total flow of $150 \mathrm{sccm}$ is used for each set. The Gas Chromatograph and operating conditions for calibration are given in the Appendix $B$.

For example, a stream of $\mathrm{CO} / \mathrm{He}$, is mixed with $\mathrm{Ar}$ and $\mathrm{H}_{2}$. The amount of each gas in the mixture is determined before injection. The mixture is injected automatically into the GC injection port from the sampling loop using auto-injector. The temperature and pressure in the loop are noted. The GC output in the form of peak areas from the TCD is noted. The calculations are given below.

Volume of the GC sampling loop: $0.5 \mathrm{cc}$

Fraction of the gas species " $X$ " in the injected sample, $f=$ Volume of $X /$ (Volume of the gas mixture).

Where "X" corresponds to $\mathrm{CH}_{4}, \mathrm{He}, \mathrm{CO}_{2}, \mathrm{H}_{2}$, and $\mathrm{CO}$

Volume of the species " $X$ " in the loop, $V_{2}=\left(f^{\star} 0.5\right) \mathrm{cc}$.

Temperature of the loop $=T_{2} K$

Absolute pressure in the loop $=\mathrm{P}_{2}$ atm

Assuming ideal gas law holds good for all the gas species, $\mathrm{V} 1=\left(\mathrm{P}_{2} / \mathrm{P}_{1}\right)^{*}\left(\mathrm{~T}_{1} / \mathrm{T}_{2}\right)^{*} \mathrm{~V}_{2}$ 
Where $\mathrm{V}_{1}=$ volume of the species " $\mathrm{X}$ " in the loop at STP conditions, cc

$\mathrm{P}_{1}=$ atmospheric pressure, $1 \mathrm{~atm}$

$\mathrm{T}_{1}=$ temperature at STP conditions, $273 \mathrm{~K}$

The moles of species ' $X$ ' in the loop, $n_{1}=V_{1} / 22400$

For example, a peak of Area A1 is obtained for particular fraction of the gas in the mixture. Similarly, for different fractions of $f$, the area counts $A$ are observed and corresponding moles are calculated. A plot of areas and corresponding moles is obtained as calibration curve. The slopes thus obtained from these plots are used for product analysis. The slope has a unit of area count.mole. The average slopes obtained for all the gases used are given in Table 16. 
Table 16. Average slopes of calibration curves of TCD gases

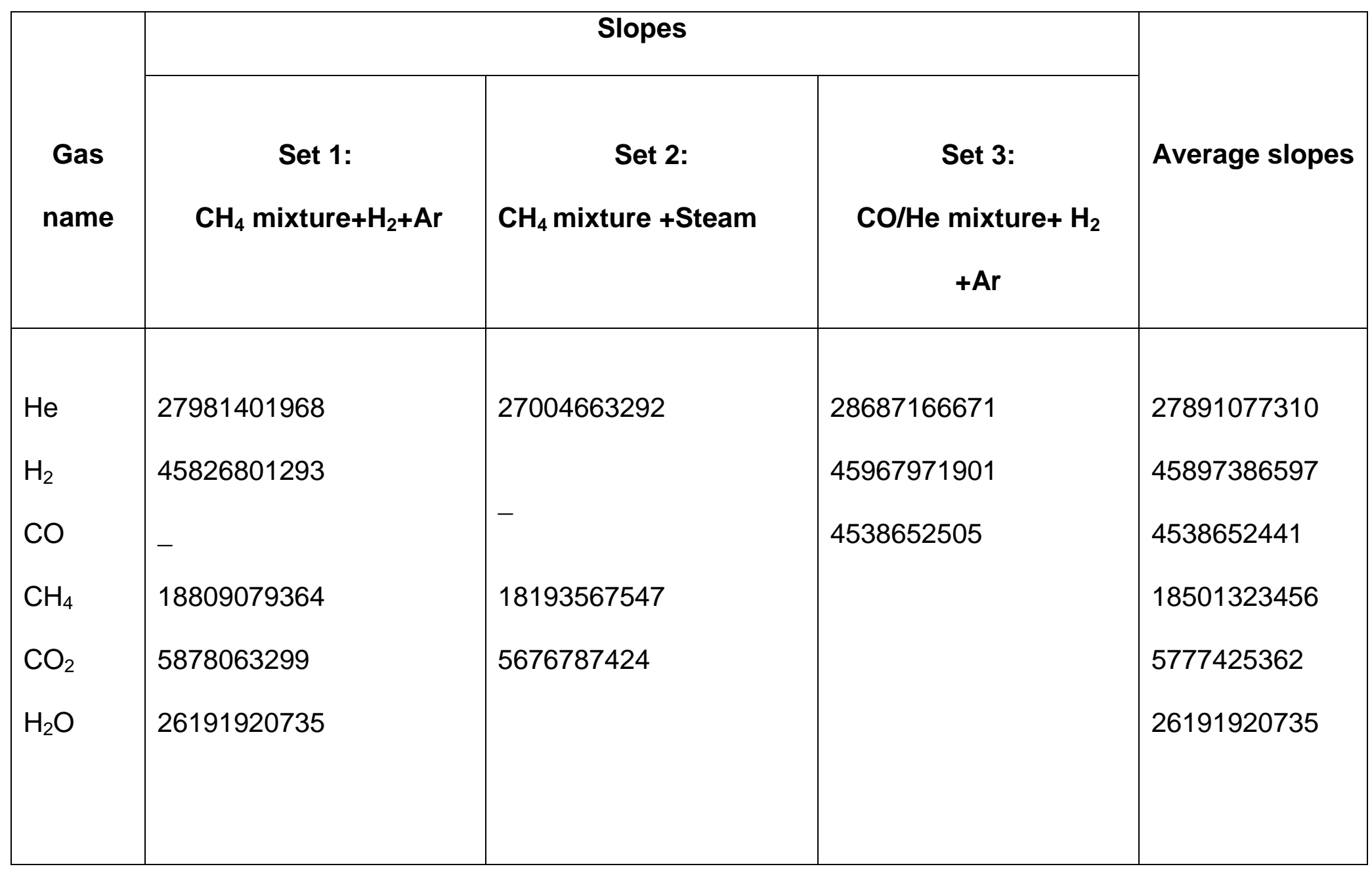




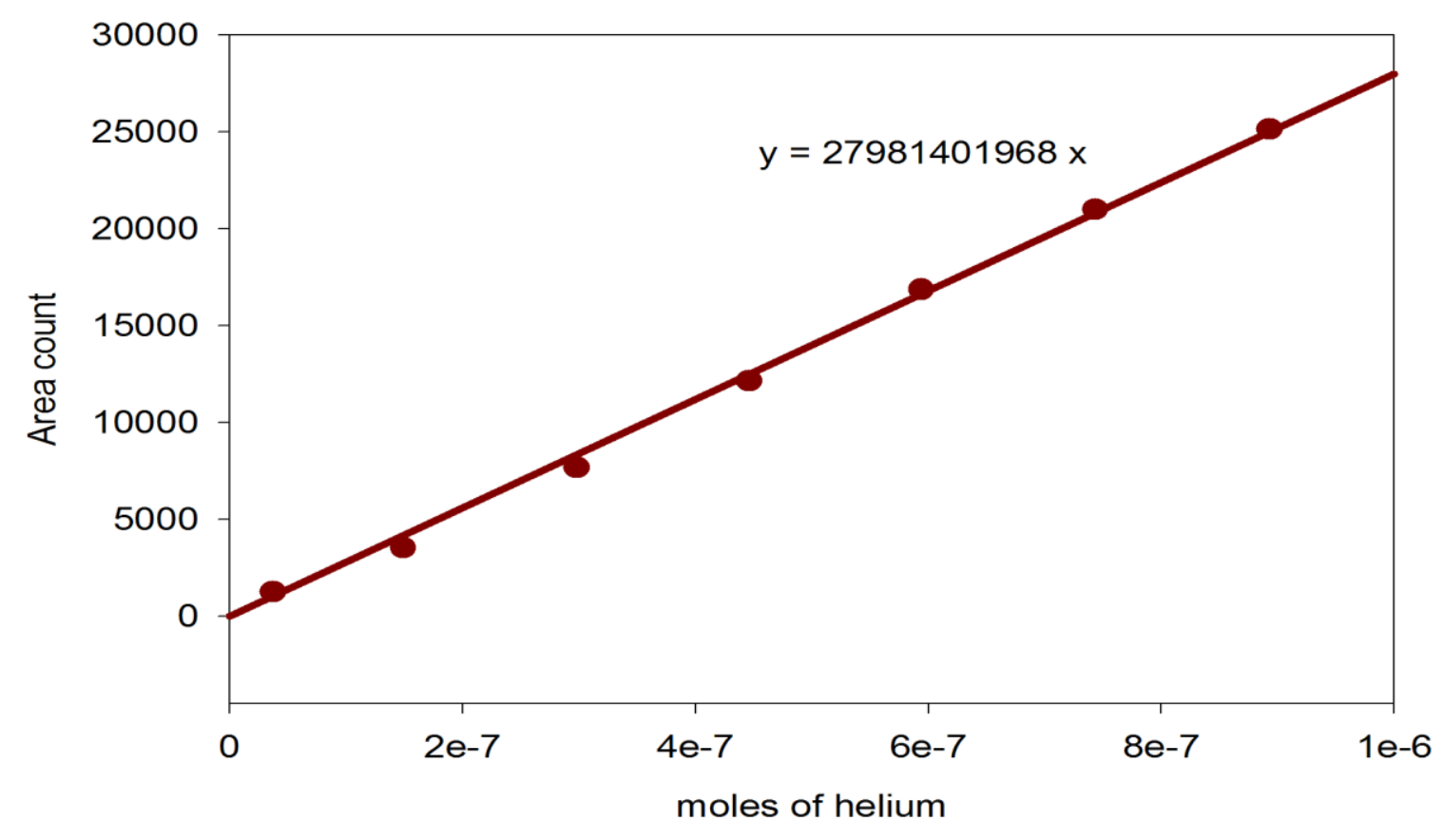

Figure 53. Calibration curve for helium using $\mathrm{CH}_{4}$ mixture diluted with steam.

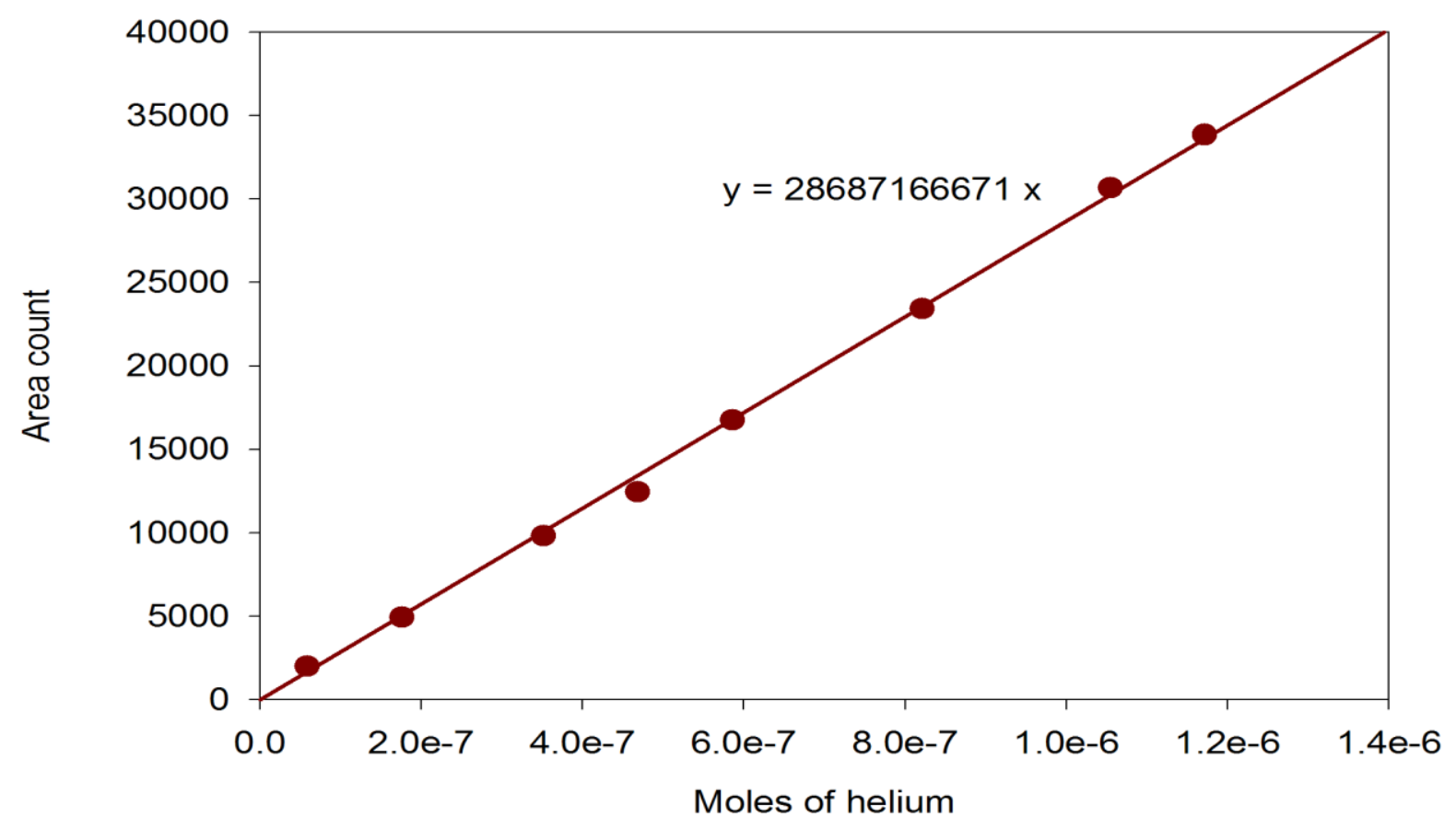

Figure 54. Calibration curve for helium using $\mathrm{CO} / \mathrm{He}$ mixture diluted with hydrogen, and argon. 


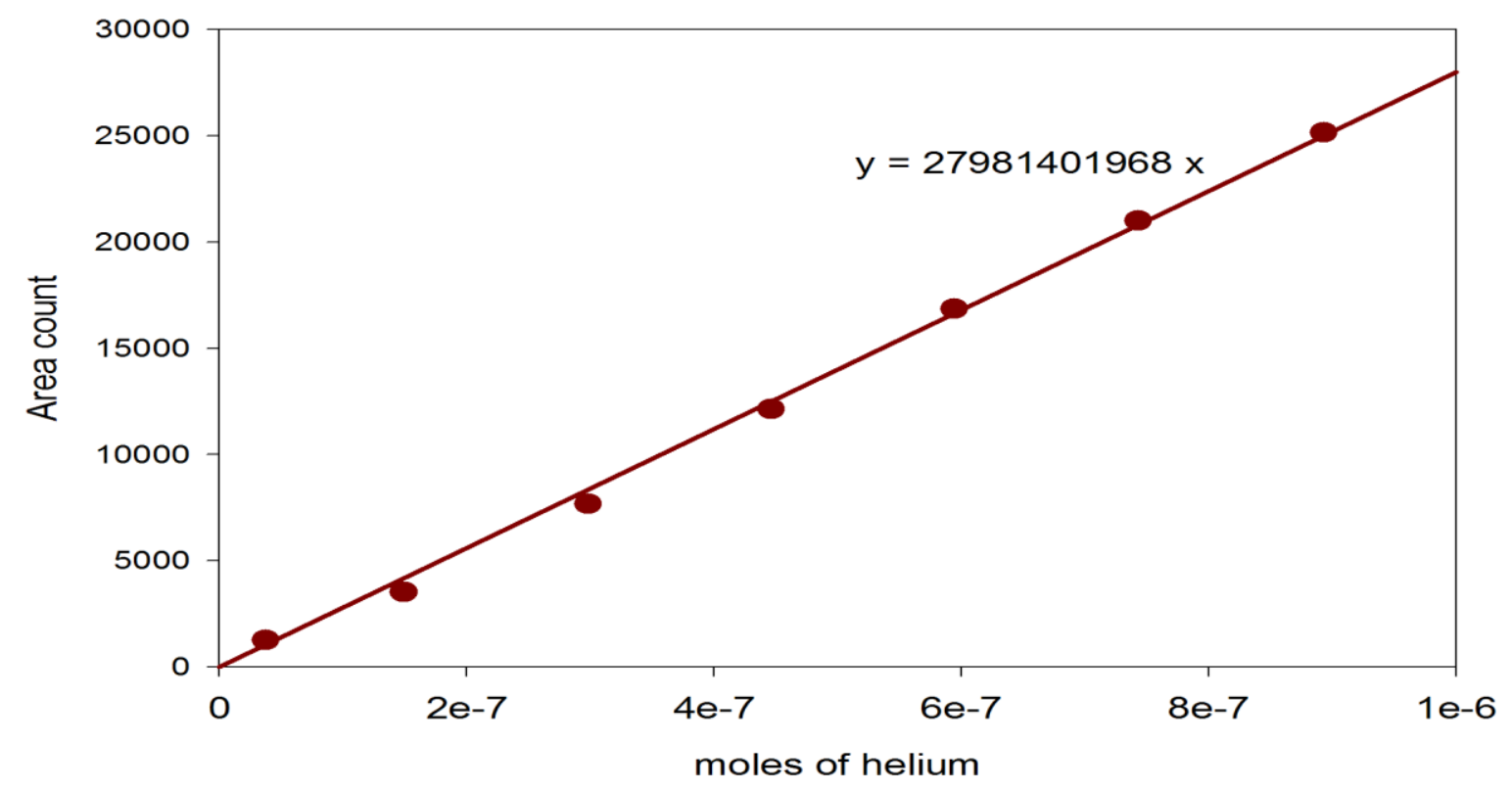

Figure 55. Calibration curve for $\mathrm{He}$ using $\mathrm{CH}_{4}$ mixture diluted with hydrogen and argon.

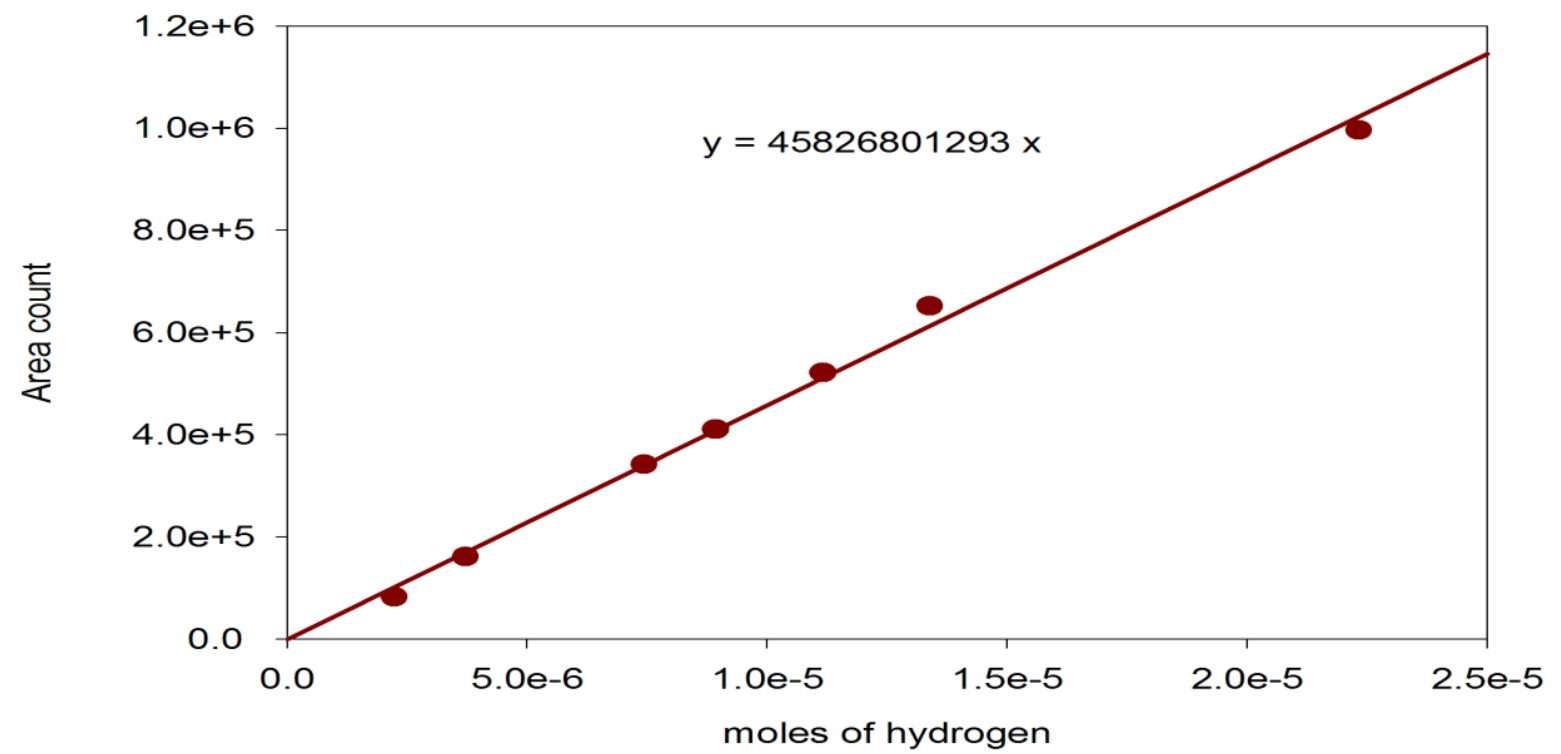

Figure 56. Calibration curve for $\mathrm{H}_{2}$ using $\mathrm{CH}_{4}$ mixture diluted with argon and hydrogen. 


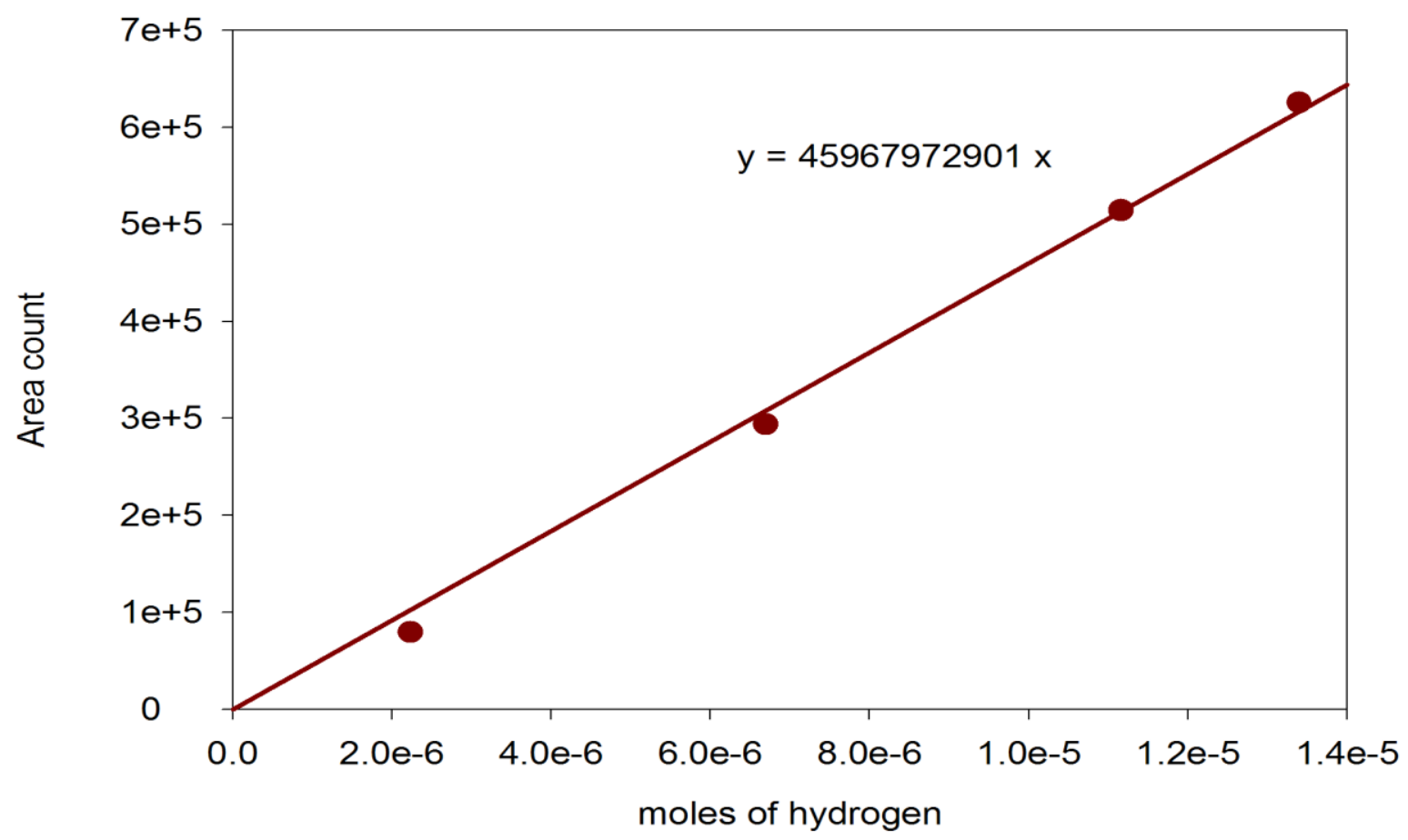

Figure 57. Calibration curve for hydrogen using $\mathrm{CH}_{4}$ mixture and argon.

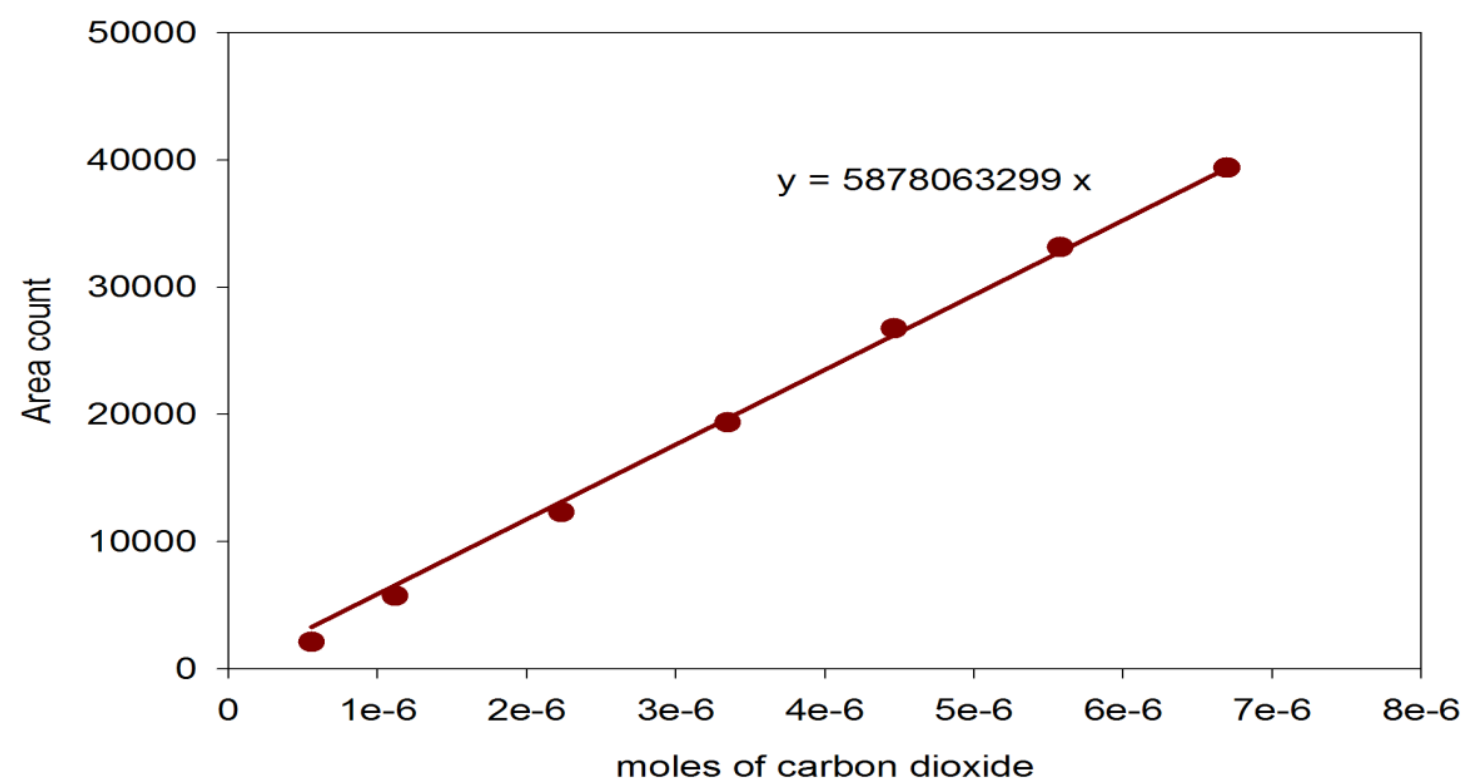

Figure 58. Calibration curve for $\mathrm{CO}_{2}$ using $\mathrm{CH}_{4}$ mixture diluted with hydrogen and argon. 


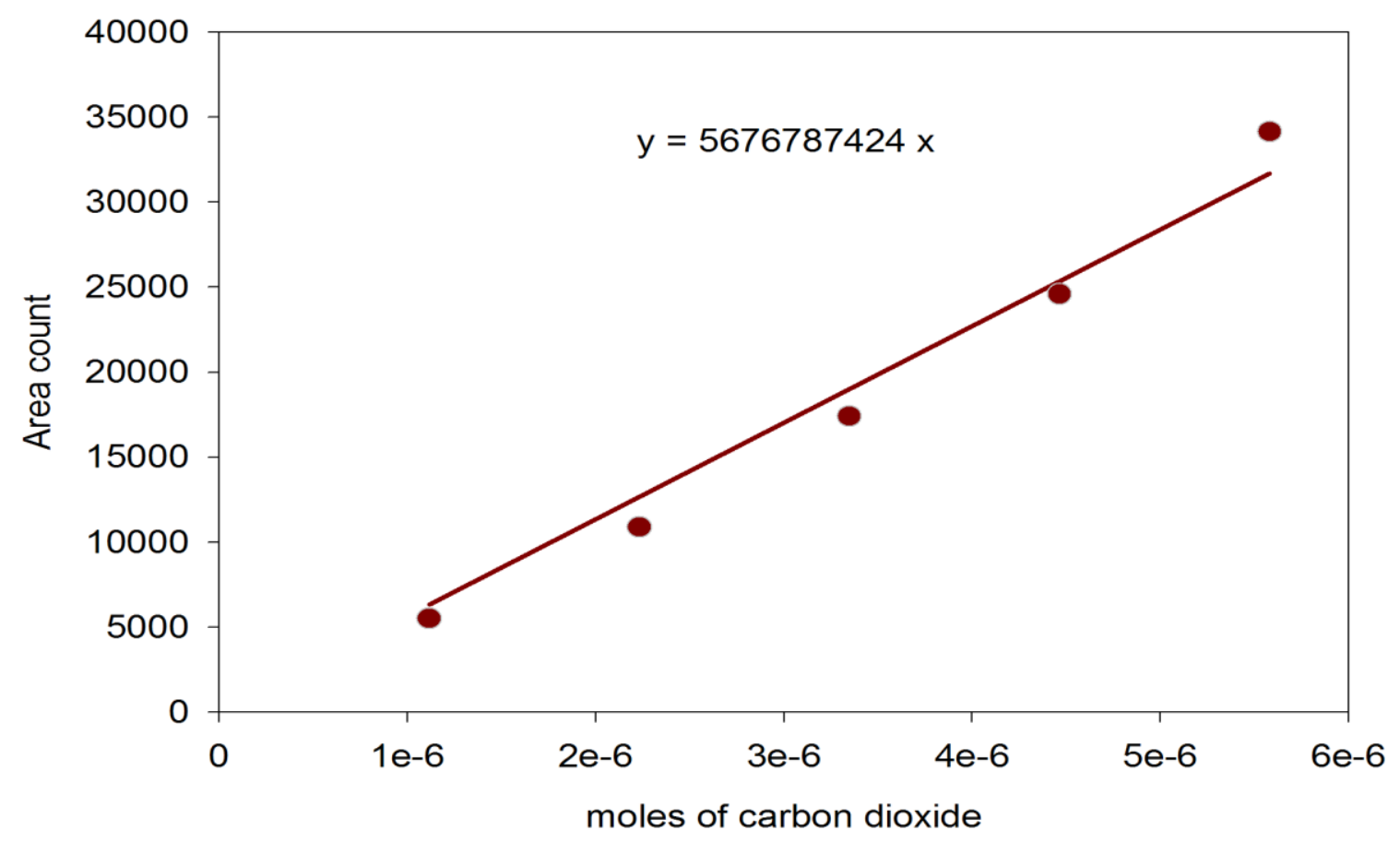

Figure 59. Calibration curve for $\mathrm{CO}_{2}$ using $\mathrm{CH}_{4}$ mixture diluted with steam.

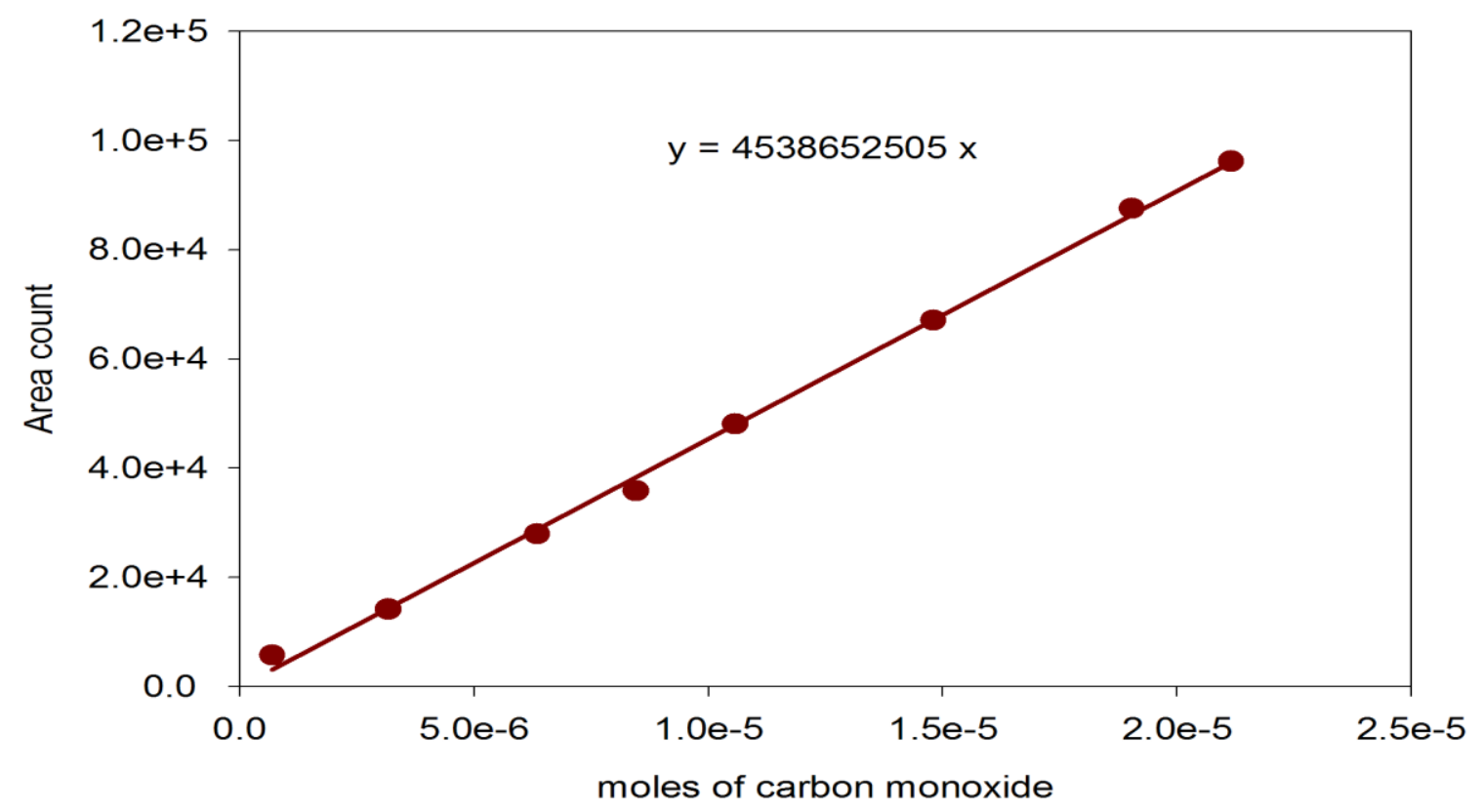

Figure 60. Calibration curve for $\mathrm{CO}$ using $\mathrm{CO} / \mathrm{He}$ mixture diluted with hydrogen and argon. 


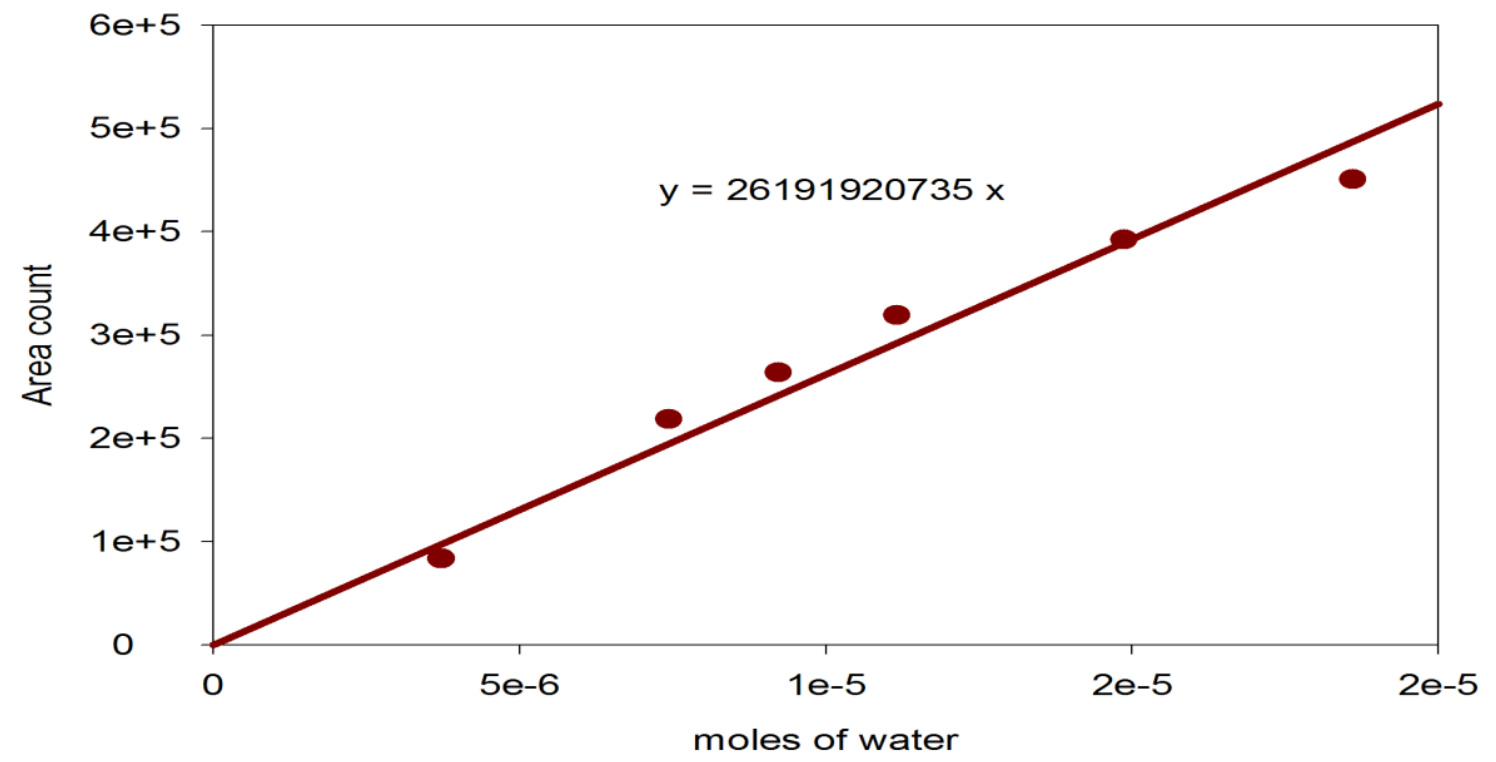

Figure 61. Calibration curve for $\mathrm{H}_{2} \mathrm{O}$ using $\mathrm{CH}_{4}$ mixture diluted with hydrogen and argon. 


\section{APPENDIX D: Calculation procedure for Relative Response Factors}

The relative-responsive factor, $\mathrm{rRF}$, is a measure of the relative response of the instrument detector to an analyte compared to an internal standard. Helium gas was used as internal standard and based on Helium; relative response factors of gases were calculated. Since the gases have different thermal conductivities, they have various retention times on Thermal Conductivity Detector (TCD). In order to get accurate quantification of each gas, rRF was used. Known quantities of each gas are sent into the GC along with known quantities of internal standard. The rRF can be calculated using the formula:

$$
(r R F)_{X}=\frac{A_{X}}{C_{X}} / \frac{A_{H e}}{C_{H e}}=\text { Slope of } x / \text { Slope of He }
$$

where $A_{x}$ is the area of $x\left(x=C_{2}, C O, H_{2} O\right.$, and $\left.H_{2}\right), A_{H e}$ is the area of helium (internal standard). $\mathrm{C}_{\mathrm{x}}$ is the known concentration of $\mathrm{x}\left(\mathrm{x}=\mathrm{CO}_{2}, \mathrm{CO}, \mathrm{H}_{2} \mathrm{O}\right.$, and $\left.\mathrm{H}_{2}\right)$ and $\mathrm{C}_{\mathrm{He}}$ is the known concentration of helium. The relative responsive factor (rRF) of all the gases are calculates using average slopes from Table16 .The rRF and retention time of each gas is given in Table 17. 
Table 17. Relative response factors of gases used for WGS reaction

\begin{tabular}{|c|c|c|}
\hline Gas & Retention time (min) & Relative Responsive Factor \\
\hline $\mathrm{He}$ & 2.319 & 1 \\
\hline $\mathrm{H}_{2}$ & 2.708 & 1.645593 \\
\hline $\mathrm{CO}$ & 3.461 & 0.16272 \\
\hline $\mathrm{CO}_{2}$ & 6.470 & 0.2071406 \\
\hline $\mathrm{CH}_{4}$ & - & 0.663341 \\
\hline $\mathrm{H}_{2} \mathrm{O}$ & 13.038 & 0.939 \\
\hline
\end{tabular}




\section{APPENDIX E: Calculation procedure for equilibrium conversions $\left(X_{e}\right)$ of WGS reaction}

The equilibrium constant $\left(\mathrm{K}_{\mathrm{e}}\right)$ of the equi-molar water-gas shift reaction can be expressed as:

$$
K_{e q}=\left[\frac{C_{A_{0}} X_{e} \times C_{A_{0}} X_{e}}{C_{A_{0}}\left(1-X_{e}\right) \times C_{A_{0}}\left(M-X_{e}\right)}\right]
$$

Where,

$\mathrm{C}_{\mathrm{A}_{0}}=$ initial concentration of carbon monoxide (CO)

$\mathrm{M}=$ ratio of steam to carbon monoxide $\left(\mathrm{H}_{2} \mathrm{O} / \mathrm{CO}\right)$

$X_{e}=$ equilibrium conversion of WGS reaction

The equilibrium constant $(\mathrm{Ke})$ can written as

$$
K_{e q}=\frac{X_{e}^{2}}{\left[\left(1-X_{e}\right) \times\left(M-X_{e}\right)\right]}
$$

The equilibrium conversions $X_{e}$ of WGS reaction are calculated within the range of 350-750 ${ }^{\circ} \mathrm{C}$ using corresponding $\mathrm{K}_{\mathrm{e}}$ values.

\section{Example calculation:}

The value of equilibrium constant $\left(\mathrm{K}_{\mathrm{e}}\right)$ at $500{ }^{\circ} \mathrm{C}=4.878, \mathrm{H}_{2} \mathrm{O} / \mathrm{CO}: 2: 1$

The equilibrium conversion of WGS reaction at $500^{\circ} \mathrm{C}$ is calculated by

substituting the values of $\mathrm{H}_{2} \mathrm{O} / \mathrm{CO}$ ratio and $\mathrm{K}_{\mathrm{e}}$ at $500{ }^{\circ} \mathrm{C}$ in the equation 2

$$
\begin{aligned}
& 4.878=\frac{X_{e}^{2}}{\left[\left(1-X_{e}\right) \times\left(2-X_{e}\right)\right]} \\
& 0.79499 X_{e}^{2}-3 X_{e}+2=0
\end{aligned}
$$


By solving the quadratic equation, equilibrium $\left(X_{e}\right)$ conversion is calculated to be:

0.8654

\section{APPENDIX F: Calculation procedure for effect of sorbent presence on equilibrium $\mathrm{CO}$ conversion $\left(\mathrm{X}_{\mathrm{e}}\right)$}

The equilibrium constant $\left(\mathrm{K}_{\mathrm{e}}\right)$ of the equi-molar water-gas shift reaction can be expressed as below:

$$
K_{e q}=\left[\frac{C_{A_{0}} X_{e} \times C_{A_{0}} X_{e}}{C_{A_{0}}\left(1-X_{e}\right) \times C_{A_{0}}\left(M-X_{e}\right)}\right]
$$

Where,

$\mathrm{C}_{\mathrm{A}_{0}}=$ initial concentration of carbon monoxide (CO)

$M=$ ratio of steam to carbon monoxide $\left(\mathrm{H}_{2} \mathrm{O} / \mathrm{CO}\right)$

$\mathrm{X}_{\mathrm{e}}=$ equilibrium conversion of WGS reaction .

For example, if the sorbent adsorbs $75 \%$ of the carbon dioxide produced in the reaction, then the equation 1 can be written as

$$
\begin{aligned}
& \mathrm{K}_{\text {eq }}=\frac{\mathrm{C}_{\mathrm{A}_{0}} \mathrm{X}_{\mathrm{e}} \times(1-0.75) \times \mathrm{C}_{\mathrm{A}_{0}} \mathrm{X}_{\mathrm{e}}}{\mathrm{C}_{\mathrm{A}_{0}}{ }^{2}\left[\left(1-\mathrm{X}_{\mathrm{e}}\right) \times\left(\mathrm{M}-\mathrm{X}_{\mathrm{e}}\right)\right]} \\
& \mathrm{K}_{\mathrm{eq}}=\frac{0.25 \mathrm{C}_{\mathrm{A}_{0}}{ }^{2} \mathrm{X}_{\mathrm{e}}{ }^{2}}{\mathrm{C}_{\mathrm{A}_{0}}{ }^{2}\left[\left(1-\mathrm{X}_{\mathrm{e}}\right) \times\left(\mathrm{M}-\mathrm{X}_{\mathrm{e}}\right)\right]}
\end{aligned}
$$

The equilibrium conversion $X_{e}$ of WGS reaction in the presence of sorbent that can capture $75 \%$ of the $\mathrm{CO}_{2}$ produced in the reaction is calculated at $500{ }^{\circ} \mathrm{C}$ for various $\mathrm{H}_{2} \mathrm{O} / \mathrm{CO}$ ratios.

\section{Example calculation:}


The value of equilibrium constant $\left(\mathrm{K}_{\mathrm{e}}\right)$ at $500{ }^{\circ} \mathrm{C}=4.878$

The ratio of $\mathrm{H}_{2} \mathrm{O} / \mathrm{CO}$ used: $2: 1$

The equilibrium conversion of WGS reaction at $500{ }^{\circ} \mathrm{C}$ is calculated by substituting the values of $\mathrm{H}_{2} \mathrm{O} / \mathrm{CO}$ ratio and $\mathrm{K}_{\mathrm{e}}$ at $500{ }^{\circ} \mathrm{C}$ in the equation 2

$$
\begin{aligned}
4.878= & \frac{0.25 X_{e}^{2}}{\left[\left(1-X_{e}\right) \times\left(2-X_{e}\right)\right]} \\
& 0.948749 X_{e}^{2}-3 X_{e}+2=0
\end{aligned}
$$

By solving the quadratic equation, equilibrium $\left(X_{e}\right)$ conversion is calculated to be:

0.9552 


\section{APPENDIX G: Calculation procedure for preparation of $\mathrm{CaO} / \mathrm{Ca}_{12} \mathrm{Al}_{14} \mathrm{O}_{33}$ sorbent in various ratios}

Amount of precursors used for preparation of $\mathrm{CaO} / \mathrm{Ca}_{12} \mathrm{Al}_{14} \mathrm{O}_{33}$ sorbent:

For $\mathrm{CaO} / \mathrm{Ca}_{12} \mathrm{Al}_{14} \mathrm{O}_{33}(75 / 25$ wt \%)

Weight of $\mathrm{CaO}: 34.85 \mathrm{~g}$

Weight of $\left(\mathrm{AlNO}_{3}\right)_{3} \cdot 9 \mathrm{H}_{2} \mathrm{O}: 37.89 \mathrm{~g}$

Distilled water: $760 \mathrm{ml}$

2-propanol: $150 \mathrm{ml}$

For $\mathrm{CaO} / \mathrm{Ca}_{12} \mathrm{Al}_{14} \mathrm{O}_{33}(50 / 50$ wt \%)

Weight of $\mathrm{CaO}: 34.85 \mathrm{~g}$

Weight of $\left(\mathrm{AlNO}_{3}\right)_{3} \cdot 9 \mathrm{H}_{2} \mathrm{O}: 37.89 \mathrm{~g}$

Molecular weights of precursors and products

Molecular weight of $\mathrm{CaO}: 56 \mathrm{~g}$

Molecular weight of $\mathrm{Ca}_{12} \mathrm{Al}_{14} \mathrm{O}_{33}: 1385.72 \mathrm{~g}$

Molecular weight of $\left(\mathrm{AlNO}_{3}\right)_{3} \cdot 9 \mathrm{H}_{2} \mathrm{O}: 374.98 \mathrm{~g}$

The decomposition of aluminum nitrate is expressed as:

$4 \mathrm{~A}\left(\mathrm{NO}_{3}\right)_{3} \Leftrightarrow 2 \mathrm{Al}_{2} \mathrm{O}_{3}+12 \mathrm{NO}_{2}+3 \mathrm{O}_{2}$

From the above equation 1, 4 moles of aluminum nitrate produces 2 moles of aluminum oxide or $749.96(2 \times 374.18) \mathrm{g}$ of aluminum nitrate produces $101.96 \mathrm{~g}$ of $\mathrm{Al}_{2} \mathrm{O}_{3}$

Therefore $37.89 \mathrm{~g}$ of aluminum nitrate produces $5.153 \mathrm{~g}$ of $\mathrm{Al}_{2} \mathrm{O}_{3}$

Formation of mayenite $\left(\mathrm{Ca}_{12} \mathrm{Al}_{14} \mathrm{O}_{33}\right)$ expressed as: 
$7 \mathrm{Al}_{2} \mathrm{O}_{3}+12 \mathrm{CaO} \Leftrightarrow \mathrm{Ca}_{12} \mathrm{Al}_{14} \mathrm{O}_{33}$

From the equation 2, $713.72 \mathrm{~g}$ of $\mathrm{Al}_{2} \mathrm{O}_{3}$ requires $672 \mathrm{~g}$ of $\mathrm{CaO}$ to produce $1385.72 \mathrm{~g}$ of $\mathrm{Ca}_{12} \mathrm{Al}_{14} \mathrm{O}_{33}$.

Also, $713.72 \mathrm{~g}$ of $\mathrm{Al}_{2} \mathrm{O}_{3}$ or $672 \mathrm{~g}$ of $\mathrm{CaO}$ will produce $1385.72 \mathrm{~g}$ of $\mathrm{Ca}_{12} \mathrm{Al}_{14} \mathrm{O}_{33}$ Therefore, $5.15 \mathrm{~g}$ of $\mathrm{Al}_{2} \mathrm{O}_{3}$ requires $4.85 \mathrm{~g}$ of $\mathrm{CaO}$ to produce $10 \mathrm{~g}$ of $\mathrm{Ca}_{12} \mathrm{Al}_{14} \mathrm{O}_{33}$ Amount of unreacted $\mathrm{CaO}=34.85092-4.85092=30 \mathrm{~g}$ Amount of $\mathrm{Ca}_{12} \mathrm{Al}_{14} \mathrm{O}_{33}$ formed $=10 \mathrm{~g}$ Percentage of $\mathrm{Ca}_{12} \mathrm{Al}_{14} \mathrm{O}_{33}$ in the total amount $=(10 / 40) \times 100=25 \%$ Percentage of $\mathrm{CaO}$ in the total amount $=(30 / 40)^{*} 100=75 \%$ The sorbent $\mathrm{CaO} / \mathrm{Ca}_{12} \mathrm{Al}_{14} \mathrm{O}_{33}(50 / 50 \mathrm{wt} \%)$ is prepared using the same procedure described above. 


\section{APPENDIX H: Calculation procedure for determination of kinetic parameters of WGS reaction}

\section{Kinetics of WGS reaction}

Assuming both sides of the WGS reaction to be of first order in each component, the forward and reverse kinetic parameters, $k_{f}$ and $k_{r}$ were calculated. The activation energy $\left(E_{a}\right)$ and pre-exponential factor $\left(k_{0}\right)$ of the WGS reaction are calculated using Arrhenius equation. The rate equation for the reverse WGS reaction given is:

$-r=k_{f}\left[\mathrm{PCO}_{\mathrm{CO}}\right]\left[\mathrm{P}_{2} \mathrm{O}\right]-\mathrm{k}_{\mathrm{r}}\left[\mathrm{P}_{2}\right]\left[\mathrm{PCO}_{2}\right]$

where,

$-r=$ rate of reaction of $\mathrm{CO}, \mathrm{H}_{2} \mathrm{O}$

$\mathrm{PCO}_{\mathrm{C}} \mathrm{P}_{2} \mathrm{O}, \mathrm{P}_{\mathrm{H}_{2}}, \mathrm{PCO}_{2}$ are the partial pressures of $\mathrm{CO}, \mathrm{H}_{2} \mathrm{O}, \mathrm{H}_{2}$, and $\mathrm{CO}_{2}$

The equilibrium constant of the WGS reaction interms of forward and backward reaction constants is given below:

$K_{e}=\frac{k_{f}}{k_{r}}$

Therefore, by substituting $\mathrm{k}_{\mathrm{r}}$ in equation 1 with $k_{r}=K_{e} \times k_{f}$, and rearranging, the expression obtained is:

$-r=k_{f}[\mathrm{PCO}]\left[\mathrm{P}_{2} \mathrm{O}\right]-\left(\mathrm{k}_{\mathrm{f}} / \mathrm{K}_{\mathrm{e}}\right)\left[\mathrm{P}_{2}\right]\left[\mathrm{PCO}_{2}\right]$

The rate constant, $\mathrm{k}_{\mathrm{f}}$ is related to the absolute temperature $(\mathrm{T})$ by:

$\mathrm{k}=\mathrm{k}_{\mathrm{o}} \exp \left\{-\mathrm{E}_{\mathrm{a}} / \mathrm{RT}\right\}$

$\mathrm{K}_{0}=$ pre-exponential factor $\left(\mathrm{mol} / \mathrm{min} / \mathrm{g}\right.$ catalyst $/(\mathrm{atm})^{2}$

$E_{a}=$ activation energy $(\mathrm{kJ} / / \mathrm{mol})$ 
$R=$ universal gas constant $(\mathrm{J} / \mathrm{mol} . \mathrm{K})$

$\mathrm{T}=$ reaction temperature $(\mathrm{K})$

\section{Example calculation:}

Total pressure of the reactor: $1 \mathrm{~atm}$

Inlet flow rate of CO: 0.002075893 (moles $/ \mathrm{min})$

Inlet flow rate of $\mathrm{H}_{2} \mathrm{O}: 0.0039444$ (moles/min)

Outlet flow rate $F_{X}(\mathrm{~mol} / \mathrm{min})$ of products at steady state during the WGS reaction at $450^{\circ} \mathrm{C}$ :

$\mathrm{F}_{\mathrm{CO}}(\mathrm{mol} / \mathrm{min}): 0.00628645$

$\mathrm{F}_{\mathrm{CO}_{2}}(\mathrm{~mol} / \mathrm{min}): 0.001447248$

$\mathrm{F}_{\mathrm{H}_{2}}(\mathrm{~mol} / \mathrm{min}): 0.001422158$

$\mathrm{F}_{\mathrm{H}_{2} \mathrm{O}}(\mathrm{mol} / \mathrm{min}): 0.0024971$

Partial pressures of products obtained during the WGS reaction at $450^{\circ} \mathrm{C}$ are calculated using the equation 4 :

$$
P X=\left(\frac{F_{X}}{\sum_{X}\left(F_{X}\right) \text { OUT }+\left(F_{H e}\right) I N+\left(F_{A r}\right) I N}\right) \times P_{T}
$$

where,

$\mathrm{P}_{\mathrm{X}}=$ partial pressure of $\mathrm{CO}, \mathrm{CO}_{2}, \mathrm{H}_{2}$, and $\mathrm{H}_{2} \mathrm{O}$

$\mathrm{F}_{\mathrm{X}}=$ outlet flow rate of $\mathrm{CO}, \mathrm{CO}_{2}, \mathrm{H}_{2}$, and $\mathrm{H}_{2} \mathrm{O}$

$\mathrm{F}_{\mathrm{He}}=$ inlet flow rate of the helium $(\mathrm{mol} / \mathrm{min})$

$\mathrm{F}_{\mathrm{Ar}}=$ inlet flow rate of the argon $(\mathrm{mol} / \mathrm{min})$ 
By substituting $F_{X}$ values in the equation 4, the corresponding partial pressures of product gases obtained are:

$\mathrm{P}_{\mathrm{CO}}=0.0700826(\mathrm{~atm}), \mathrm{P}_{\mathrm{Ar}}=0.31934(\mathrm{~atm}), \mathrm{P}_{\mathrm{He}}=0.01230(\mathrm{~atm})$

$\mathrm{P}_{\mathrm{CO}_{2}}=0.01447(\mathrm{~atm}), \mathrm{P}_{\mathrm{H}_{2}}=0.15854(\mathrm{~atm}), \mathrm{P}_{\mathrm{H}_{2} \mathrm{O}}=0.27838(\mathrm{~atm})$

Equilibrium constant $\left(\mathrm{K}_{\mathrm{e}}\right)$ of the WGS reaction at $450{ }^{\circ} \mathrm{C}: 7.31$

Rate of consumption of $\mathrm{CO}(\mathrm{mol} / \mathrm{min} \cdot \mathrm{g}$ catalyst $): \frac{\mathrm{CO}_{\text {in }}-\mathrm{CO}_{\text {out }}(\mathrm{mol} / \mathrm{min})}{\text { catalyst weight }(\mathrm{g})}$

$$
=\frac{0.002075893-0.00628645}{0.2}
$$

$=0.00723624(\mathrm{~mol} / \mathrm{min} \cdot \mathrm{g}$ catalyst $)$

By substituting partial pressures of all the gases in the product, equilibrium constant $\left(\mathrm{K}_{\mathrm{e}}\right)$ at $450^{\circ} \mathrm{C}$, and rate of consumption of $\mathrm{CO}$ in the equation 1 , the corresponding forward reaction constant $\left(\mathrm{k}_{\mathrm{f}}\right)$ calculated is:

$0.007524684(\mathrm{~mol} / \mathrm{sec} / \mathrm{g} \text { catalyst/ atm })^{2}$

The backward reaction constant $\mathrm{k}_{\mathrm{r}}$ is calculated as:

$$
\begin{aligned}
\mathrm{k}_{\mathrm{r}} & =\left(\mathrm{k}_{\mathrm{f}} / \mathrm{K}_{\mathrm{e}}\right) \\
& =(0.007524684 / 7.34644) \\
& =0.001024263 \mathrm{~mol} / \mathrm{sec} / \mathrm{g} \text { catalyst } /(\mathrm{atm})^{2}
\end{aligned}
$$




\section{APPENDIX I: Calculation procedure for $\mathrm{CO}_{2}$ sorption for $\mathrm{CaO} / \mathrm{Ca}_{12} \mathrm{Al}_{14} \mathrm{O}_{33}(75 / 25 \mathrm{wt} \%)$ and catalyst separated with chips}

Step 1:

Moles of $\mathrm{CO}_{2}$ adsorbed are calculated based on $\mathrm{H}_{2}$ moles produced and $\mathrm{CO}$ reacted. Since WGS reaction is equi-molar, 1 mole of $\mathrm{CO}$ reacts with 1 mole of $\mathrm{H}_{2} \mathrm{O}$ and gives 1 mole of $\mathrm{CO}_{2}$ and 1 mole of $\mathrm{H}_{2}$.

$$
\mathrm{CO}(\mathrm{g})+\mathrm{H}_{2} \mathrm{O}(\mathrm{g}) \Leftrightarrow \mathrm{H}_{2}(\mathrm{~g})+\mathrm{CO}_{2}(\mathrm{~g})
$$

Therefore, moles of $\mathrm{CO}_{2}$ adsorbed $(\mathrm{mol} / \mathrm{min})=$ moles of $\mathrm{H}_{2}$ formed $(\mathrm{mol} / \mathrm{min})-$ moles of $\mathrm{CO}_{2}$ from the reactor outlet $(\mathrm{mol} / \mathrm{min})$. Moles of $\mathrm{CO}_{2}$ adsorbed with respect to time are calculated and given in Table18.

\section{Step 2:}

The curve representing the moles of $\mathrm{CO}_{2}$ adsorbed with respect to time is shown in Figure 62.

\section{Step 3:}

From this curve, the total amount of $\mathrm{CO}_{2}$ adsorbed between consecutive time points is determined by calculating the area under the curve using Origin 6 software or trapezoidal rule. 
Table 18. Moles of $\mathrm{CO}_{2}$ adsorbed and corresponding time

\begin{tabular}{|c|c|}
\hline Time (min) & Moles of $\mathrm{CO}_{2}$ adsorbed $(\mathrm{mol} / \mathrm{min})$ \\
\hline 3 & 0.002452313 \\
\hline 4 & 0.002430254 \\
\hline 5 & 0.002446539 \\
\hline 6 & 0.002479130 \\
\hline 7 & 0.000671289 \\
\hline 12 & 0.000182099 \\
\hline 13 & 0.000063176 \\
\hline 14 & 0.000062747 \\
\hline 15 & 0.000060863 \\
\hline 20 & 0.000058983 \\
\hline 21 & 0.000057637 \\
\hline 22 & 0.000033996 \\
\hline 23 & 0.000033105 \\
\hline 28 & 0.000029559 \\
\hline 29 & 0.000023098 \\
\hline 30 & 0.000026855 \\
\hline 31 & 0.000022228 \\
\hline 36 & 0.000014671 \\
\hline
\end{tabular}




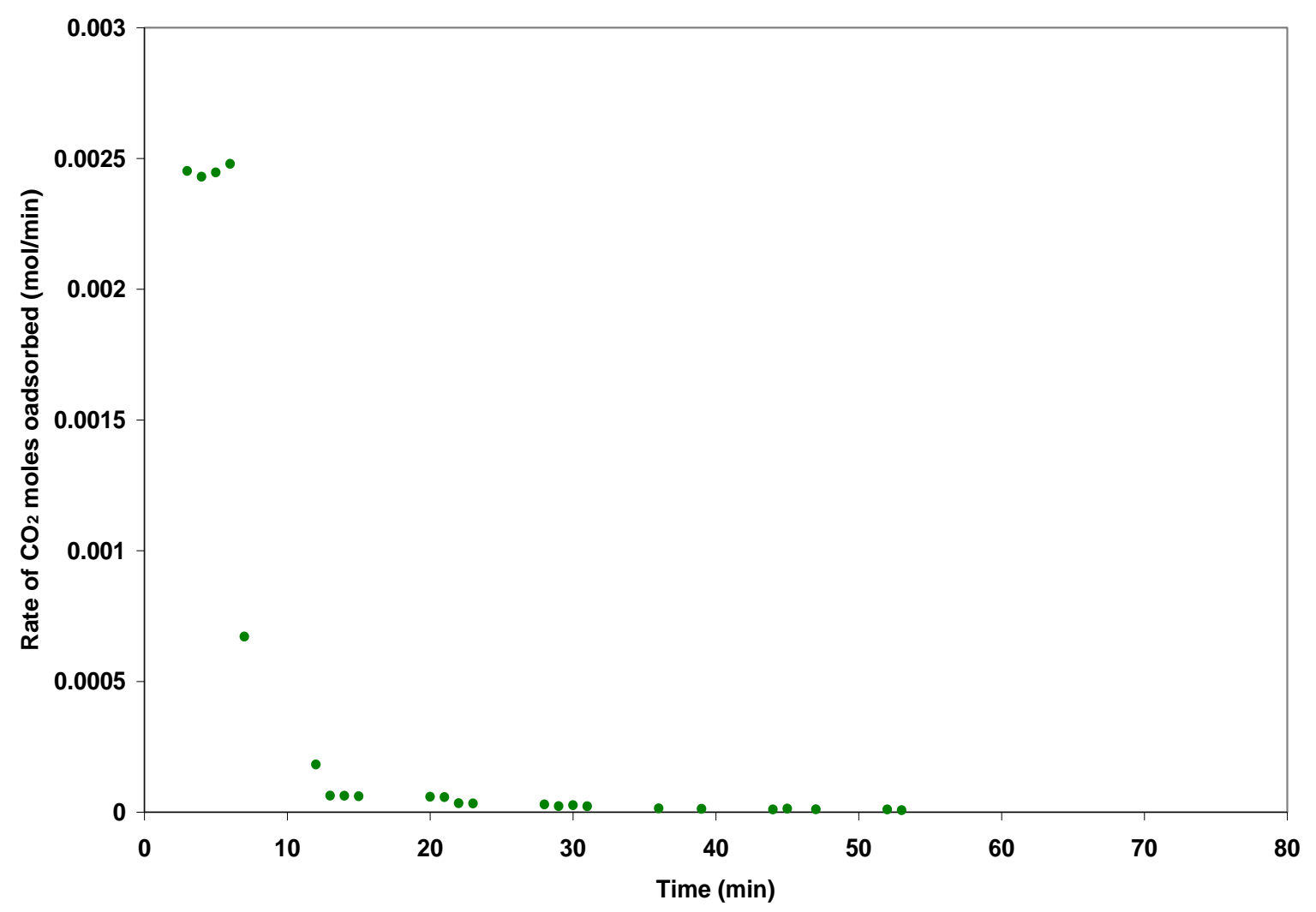

Figure 62. Moles of $\mathrm{CO}_{2}$ adsorbed with respect to time

\section{Example calculation for Moles of $\mathrm{CO}_{2}$ adsorbed $(\mathrm{mol} / \mathrm{kg})$}

\section{1). Calculation of moles of $\mathrm{CO}_{2}$ adsorbed for first 3 minutes:}

The number of moles of $\mathrm{CO}_{2}$ adsorbed at $0^{\text {th }}$ minute will be " 0 " moles. Then, we assume that the $\mathrm{CO}$ conversion will vary linearly from 0 to 3 minutes. Therefore, the region below the straight line represents the $\mathrm{CO}_{2}$ moles adsorbed up to 3 minutes.

Area of the rectangle $A B C D$ is: height $\times$ width

$$
\begin{aligned}
& : 0.002452313 \times 3 \\
& : 7.577742 \times 10^{-03} \text { moles }
\end{aligned}
$$


Therefore the area of the triangle $A B C$, which is equal to half of the area of the rectangle $A B C D$, gives the number of moles of $\mathrm{CO}_{2}$ adsorbed.

So number of moles of $\mathrm{CO}_{2}$ adsorbed up to $3 \mathrm{~min}$ will be:

$:\left(7.577742 \times 10^{-03}\right) / 2=3.788871 \times 10^{-03}$

Moles of $\mathrm{CO}_{2}$ adsorbed (per/2.5 $\mathrm{g}$ of sorbent) up to $3 \mathrm{~min}$ will be equal to $4.851828 \times 10^{-03}$. So, the moles of $\mathrm{CO}_{2}$ adsorbed per $1000 \mathrm{~g}$ will be equal to:

$=\left(3.788871 \times 10^{-03} \times 1000\right) /(2.5)$

$=1.51554 \mathrm{~mol} / \mathrm{Kg}$

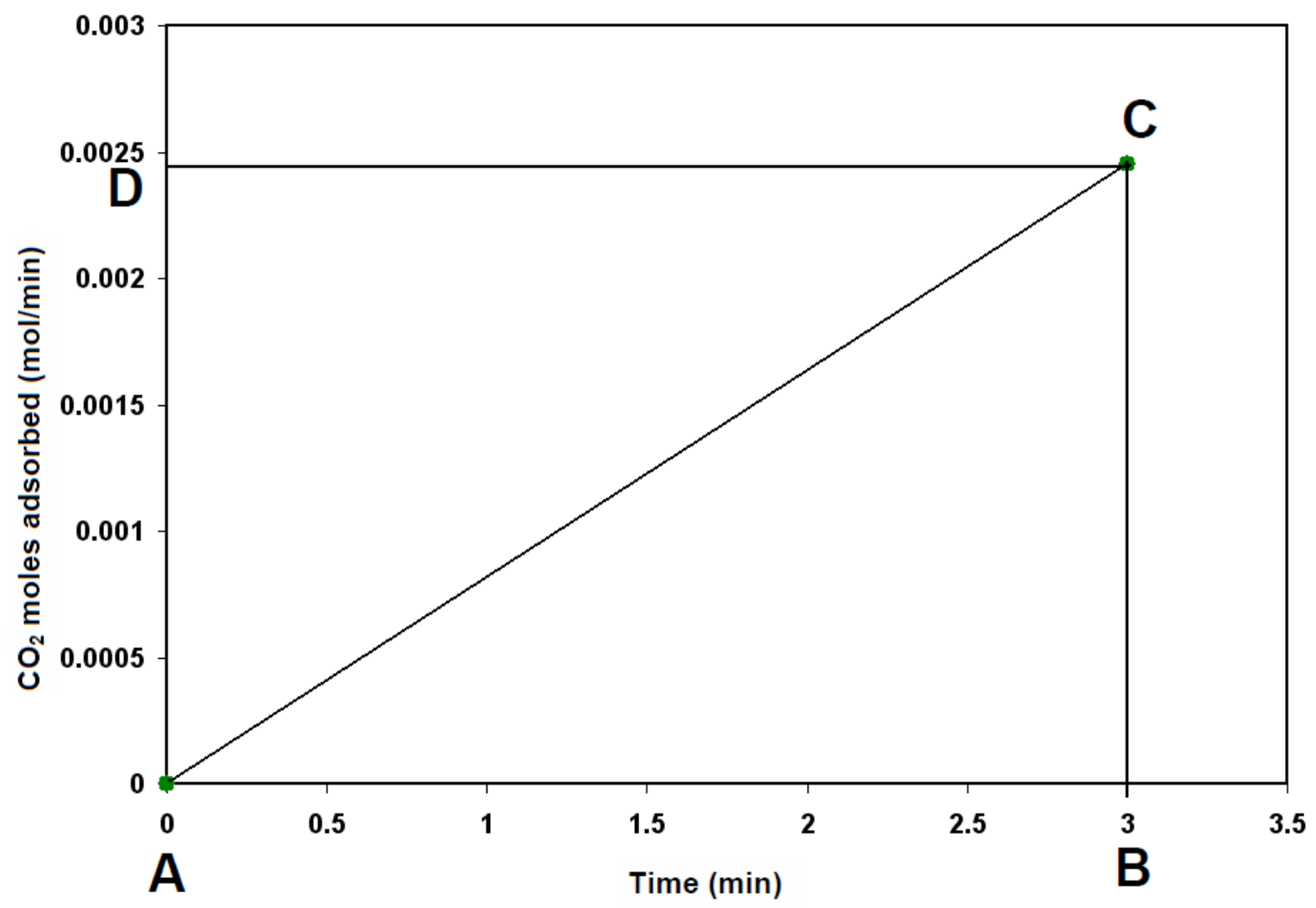

Figure 63. Moles of $\mathrm{CO}_{2}$ adsorbed with respect time

\section{At $4^{\text {th }}$ min}


Calculation for moles of $\mathrm{CO}_{2}$ adsorbed (mol/2.5 g of sorbent) for the $4^{\text {th }}$ minute:

To calculate moles of $\mathrm{CO}_{2}$ adsorbed at the $4^{\text {th }}$ minute, we need rate of moles of $\mathrm{CO}_{2}$ adsorbed at the $3^{\text {rd }}$ and the $4^{\text {th }}$ minutes

Rate of moles of $\mathrm{CO}_{2}$ adsorbed at the $3^{\text {rd }} \mathrm{min}: 0.002452313(\mathrm{~mol} / \mathrm{min})$

Rate of moles adsorbed at the $4^{\text {th }}$ minute: $0.002430254(\mathrm{~mol} / \mathrm{min})$

Using trapezoid rule or origin 6 software

Area under the curve:

$=\left(\left(\text { Height of the curve at } 3^{\text {rd }} \min +\text { Height of the curve at } 4^{\text {th }} \min \right)^{*}\left(t_{4}-t_{3}\right) / 2\right.$

$=((0.002452313+0.002430254) \times(4-3)) / 2$

$=0.002478084$ moles adsorbed per $2.5 \mathrm{gm}$ of sorbent

The calculated amount of $\mathrm{CO}_{2}$ adsorbed corresponds to $2.5 \mathrm{~g}$ of sorbent used. Hence, the amount of $\mathrm{CO}_{2}$ adsorbed for $1000 \mathrm{~g}$ of sorbent is calculated.

Moles of $\mathrm{CO}_{2}$ adsorbed per $1000 \mathrm{~g}$ of sorbent:

$$
\begin{aligned}
& =(1000 \times 0.002434042) / 2.5 \\
& =0.9912336 \mathrm{~mol} / \mathrm{kg}
\end{aligned}
$$

Similarly, the moles of $\mathrm{CO}_{2}$ adsorbed per $1000 \mathrm{~g}$ of the sorbent are calculated at each minute until the sorbent reaches its breakthrough curve. Then, the corresponding cumulative moles of $\mathrm{CO}_{2}$ adsorbed at each minute is calculated and given in Table 19. 
Table 19. Cumulative moles of $\mathrm{CO}_{2}$ adsorbed per $\mathrm{Kg}$

\begin{tabular}{|c|c|c|c|}
\hline $\begin{array}{c}\text { Time } \\
\text { (minute) }\end{array}$ & $\begin{array}{c}\mathrm{CO}_{2} \text { sorption capacity } \\
(\mathrm{mol} / \mathrm{kg})\end{array}$ & Time (min) & $\begin{array}{c}\mathrm{CO}_{2} \text { sorption capacity } \\
(\mathrm{mol} / \mathrm{kg})\end{array}$ \\
\hline 3 & 1.5155 & 20 & 6.145134176 \\
\hline 4 & 2.492013547 & 21 & 6.168458167 \\
\hline 5 & 3.467372308 & 22 & 6.186784685 \\
\hline 6 & 4.447680202 & 23 & 6.200204866 \\
\hline 7 & 5.072938064 & 28 & 6.262869162 \\
\hline 12 & 5.926326614 & 29 & 6.273400682 \\
\hline 13 & 5.9753816 & 30 & 6.283391267 \\
\hline 14 & 6.000566076 & 31 & 6.293207911 \\
\hline 15 & 6.025287976 & 36 & 6.330107858 \\
\hline
\end{tabular}




\section{References}

1. Chen, W. H., Hsieh, T. C. and Jiang, T. L. An experimental study on carbon monoxide conversion and hydrogen generation from water-gas shift reaction, Energy Conversion Management. 49 (2008) 2801-2808.

2. Balat, M. Potential importance of hydrogen as a future solution to environmental and transportation problems, International Journal of Hydrogen Energy. 33 (2008) 4013-4029.

3. Jeffrey, R. B., Michel, B. P. and Norman, K. O. An economic survey of hydrogen production from conventional and alternative energy sources, International Journal of Hydrogen Energy. 32 (2007) 3797-3810.

4. Mulur, L. F., Tzimas. E., Kaltschmit, M. and Peteves, S. Techno-economic assessment of hydrogen production processes for the hydrogen economy for the short and medium term, International Journal of Hydrogen Production. 32 (2007) 3797-3810.

5. Kothari, R., Buddhi, D. and Sawhney, R. L. Comparison of environmental and economic aspects of various hydrogen production methods, Renewable and Sustainable Energy Reviews. 12 (2008) 553-563.

6. Haryanto, A., Fernando, S., Murali, A. and Adhikari, S. Current status of hydrogen production techniques by steam reforming of ethanol: A Review, Energy Fuels. 19 (2005) 2098-2106.

7. Han, C. and Harrison, D. P. Simultaneous water-gas shift reaction and carbon dioxide separation for the direct production of hydrogen, Chemical Engineering Science. 49 (1997) 5875-5883.

8. Callaghan, C., Ilie, F., Ravindra, D., Michael, C., Matthew, C. and Anibal, L. An improved micro-kinetic model for the water-gas shift reaction on copper, Surface Science. 541(2003) 21-30.

9. Twigg, M. V. Catalysis Handbook, second edition, Manson Publishing.Ltd, London, 1996, ISBN: 1874545359.

10. Iyer, M. V., Gupta, H., Sakadjian, B. S. and Fan, L. S. High temperature $\mathrm{CO}_{2}$ capture and hydrogen production using calcium oxide: Process development 
and economics for combustion and gasification systems. Proc. Int. Tech. Conf. Coal Utilization \& Fuel Systems. 30 (2005) 419-426.

11. Quadro, E. B., Dias, M. L. R. and Amorim, A. M. M. Chromium and copper dopped magnetite catalyst for the high-temperature shift reaction, Journal of Brazilian Chemical Society. 10 (1999) 51-59.

12. Araujo, G. C. and Rangel, M. C. An environment friendly dopant for the hightemperature-shift catalysts, Catalysis Today. 62 (2000) 201-207.

13. Newsome, D. S. Catalysis Reviews, Science and Engineering. 21 (1980) 275-281.

14. Andreev, V., Idakiev, V., Mihajlova, D. and Shopov, D. Iron-based catalysts for the water-gas shift reaction promoted by first row transition metal oxides, Applied Catalysis. 22 (1986) 385-387.

15. Rhodes, C., Williams, B. P., King, F. and Hutchings, G. H. Promotion of $\mathrm{Fe}_{3} \mathrm{O}_{4} / \mathrm{Cr}_{2} \mathrm{O}_{3}$ high-temperature WGS catalyst, Catalysis Communications. 3 (2002) 381-384.

16. Liu, Q., Ma, W., He, R. and Mu, Z. Reaction and characterization studies of an industrial $\mathrm{Cr}$-free iron-based catalyst for high-temperature water-gas shift reaction, Catalysis Today. 106 (2005) 52-56.

17. Shirokov, Y. G. Khim. Khim. Tekhnol. 21 (1978) 1339-1345.

18. Rethwisch, D. G. and Dumesic, Journal of Applied Catalysis. 21 (1986) 97109.

19. Kochloefl, K. Handbook of Heterogeneous Catalysis, part B, Wiley-VCH, Weinheium, 2008, ISBN: 9783527619474.

20. Natesakhawat, S., Wang, X., Zhang, L. and Ozkan, S. U. Development of chromium-free iron-based catalysts for high-temperature water-gas shift reaction, Journal of Molecular Catalysis A: Chemical. 260 (2006) 82-94.

21. Xue, E., Keeffe, M. O. and Ross, J. R. Water-gas shift conversion using a feed with low steam-to-carbon monoxide ratio and contains sulfur, Catalysis Today. 30(1996) 107-118.

22. Ladebeck, J. R. and Wagner, J. P. Catalyst development for water-gas shift reaction, Handbook of Fuel Cells - Fundamentals, Technology and 
Applications, vol-3, John Wiley \& Sons.Ltd, Chichester, 2003, ISBN: 0-47149926-9.

23. Lee. S. Encyclopedia of Chemical Processing, third edition, Taylor \& Francis. Ltd, New York, 2005, ISBN: 978-0-8247-5563-8.

24. Jose, D. F., Timothy, F., Sean, P., Howard, M. and Rameshwar, D. S. Advances in $\mathrm{CO}_{2}$-capture technology-The U.S. Department of Energy's Carbon Sequestration Program, International Journal of Greenhouse Gas Control. 2 (2008) 9-20.

25. Bello, A. and Idem, R. O. Pathways for the formation of products of the oxidative degradation of $\mathrm{CO}_{2}$-loaded concentrated aqueous monoethanolamine solutions during $\mathrm{CO}_{2}$ absorption from flue gases, Industrial and Engineering Chemistry Research. 44 (2005) 945-969.

26. Thitakamol, B., Veawab, A. and Aroonwilas, A. Environmental impacts of absorption-based $\mathrm{CO}_{2}$ unit for post-combustion treatment of flue gas from coal-fired power plant, International Journal of Greenhouse Gases. 1(2007) 318-342.

27. Readman, J. E. and Blom, J. The use of in-situ powder X-ray diffraction in the investigation of dolomite as a potential reversible high-temperature $\mathrm{CO}_{2}$ sorbent, Physical Chemistry Chemical Physics. 7 (2005)1214-1219.

28. Siriwardane, R. V., Shen, M. S. and Fisher, E. P. Adsorption of $\mathrm{CO}_{2}$ on zeolites at moderate temperature, Energy \& Fuels.19 (2005) 1153-1159.

29. Coal generation technology \& carbon capture and storage, National Association of Regulatory Utility Commissioners (NARUC), May 2009. http://www.naruc.org/Publications/NARUC\%20CCTCCS\%20Primer\%20FINA L\%206\%2009.pdf.

30. Li, K. Ceramic membranes for separation and reaction, second edition, John Wiley \& Son. Ltd, Chichester, 2007, ISBN: 978-0-470-01440-0.

31. Gupta, H. and Fan, L. S. Carbonation-calcination cycle using high-reactivity calcium oxide for carbon dioxide separation from flue gas, Industrial and Engineering Chemistry Research. 41 (2002) 4035-4042. 
32. Silaban, A., Narcida, M. and Harrison, D. P. Characteristics of the reversible reaction between $\mathrm{CO}_{2}(\mathrm{~g})$ and calcined dolomite, Chemical Engineering Communications.146 (1996) 149-162.

33. Bandi, A., Specht, M., Sichler, M. and Nicoloso, N. In-situ gas conditions in fuel reforming for hydrogen generation, $5^{\text {th }}$ International Symposium on Gas Cleaning at High temperature, NETL, Morgantown, WV, 2002, pp 17-20.

34. Li, Z., Cai, N. and Huang, Y. Effect of preparation temperature on cyclic $\mathrm{CO}_{2}$ capture and multiple carbonation-calcination cycles for a new based $\mathrm{CO}_{2}$ sorbents, Industrial and Engineering Chemistry Research, 45 (2006)19111917.

35. Li, Z., Cai, N., Huang, Y. and Han, H. Synthesis, experimental studies, and analysis of a new calcium-based carbon dioxide absorbent, Energy \& Fuels. 19(2005) 1447-1452.

36. Nakagawa, K. and Ohashi, T. A. novel method for $\mathrm{CO}_{2}$ capture from high temperature gases, Electrochemical Society.145 (1998) 1344-1346.

37. Kato, M. $\mathrm{CO}_{2}$ separation techniques using lithium containing oxide, $6^{\text {th }}$ International Conference on Green Gas Control Technologies, Kyoto, Japan, 2003, page 1579-1582.

38. Kato, M., Kakagawa, K., Essaki, K., Maezawa, Y., Takeda, S., Kogo, R. and Hagiwara, Y. Novel $\mathrm{CO}_{2}$ Absorbents Lithium-Containing Oxide, International Journal of Applied Ceramic Technology. 2 (2005) 467-475.

39. Gauer, C. and Heschel, W. Doped lithium orthosilicate for absorption of carbon dioxide, Journal of Materials Science. 41 (2006) 2405.

40. Daniel, J. F., Elizabeth, A. F., James, S. H., Randall, P. R. and Henry, W. P, Eutectic salt promoted lithium zirconate: Novel high temperature sorbent for $\mathrm{CO}_{2}$ capture, Fuel Processing Technology. 86 (2005) 1503-1521.

41. Fernandez, E. O., Haugen, G., Zhao, T., Ronning, M., Aartun, I. and Boresen, B. Process design simulation of $\mathrm{H}_{2}$ production by sorption enhanced steam methane reforming: Evaluation of potential $\mathrm{CO}_{2}$ acceptors, Green Chemistry. 9 (2007) 654-662. 
42. Lee, S. C., Choi, B. Y., Lee, T. J., Ryu, C. K., Ahn, Y. S. and Kim, J. C. $\mathrm{CO}_{2}$ absorption and regeneration of alkali-metal-based solid sorbents, Catalysis Today. 111(2006) 385-390.

43. Lee, S. C., Chae, H. J., Park, Y. H., Ryu, C. K. and Kim, J. C. Novel regenerable potassium-based dry sorbents, Journal of Molecular Catalysis B: Enzymatic, (2007), doi:10.1016/j.molcatb.2008.07.007.

44. Yong, Z. and Rodrigues, A. E. Hydrotalcite-like compounds as adsorbent for carbon dioxide, Energy Conversion and Management. 43 (2002) 1865-1876.

45. Hufton, J. R., Mayogra, S. G. and Sircar, S. Sorption enhanced reaction process for the production of hydrogen, American Institute of Chemical Engineering. 45 (1999) 248-256.

46. Douglas, P. H. Sorption enhanced hydrogen production: Review, Industrial and Engineering Chemistry Research. 47 (2008) 6475-6481.

47. Reijers, H. T. J., Schiermeier, S. E. A. V., Odden, P. D. and Van, R. V. Hydrotalcites as $\mathrm{CO}_{2}$ sorbents for Sorption-Enhanced Reforming of Methane, Industrial and Engineering Chemistry Research. 45 (2006) 2522-2530.

48. Oliveira, E. L. J., Grande, C. A. and Rodrigues, A. E. $\mathrm{CO}_{2}$ sorption on hydrotalcites and alkali-modified hydrotalcites at high temperatures, Separation and Purification Technology. 62 (2008) 137-147.

49. Lee, K. B., Beaver, M. G., Caram, H. S. and Sircar, S. Reversible chemisorptions of carbon dioxide: Simultaneous production of fuel-cell grade $\mathrm{H}_{2}$ and compressed $\mathrm{CO}_{2}$ from synthesis gas, Adsorption. 13 (2007) 385-397.

50. Holladay, J. D., Hu, J and Wang, Y. An overview of hydrogen production technologies, Catalysis Today. 139 (2009)244-260.

51. Xuan. C., Zheng, S., Nancy, G., Haijiang, W. and Jun, S. A review of PEM hydrogen fuel cell contamination: impact, mechanism, and mitigation, Journal of Power Sources. 165 (2007) 739-756.

52. Kuo, K. K. Principles of combustion, second edition, John Wiley \& Sons. Inc, Hoboken, New Jersey, 2005, ISBN: 0-471-04689-2.

53. Mcllveen-Wright, D. R., Pinto, F., Armesto, L., Caballero, M. A., Aznar, M. P., Cabanillas, A., Huang, Y., Franco, C. and Gulyurtlu, I. A comparison of 
circulating fluidized-bed combustion and gasification power-plant technologies for processing mixtures of coal, biomass and plastic waste, Fuel Processing Technology. 87 (2006) 793-801.

54. Cayan, F. N., Zhi, M., Palaklapati, R. S., Celik, I. and Gemmen, N. R. Effect of coal syngas impurities on anodes of solid oxide fuel cells, Journal of Power Sources. 185 (2008) 595-602.

55. Bohlbro, H and Jorgensen, M. H., Chemical Engineering World. 5 (1970) 46 54.

56. Xue, E., O'Keeffe, M. and Ross, J. R. A study of $\mathrm{Pt} / \mathrm{ZrO}_{2}$ catalysts for Watergas-shift reaction in the presence of $\mathrm{H}_{2} \mathrm{~S}$, Studies in Surface Science and Catalysis. 130 (2000) 3813-3818.

57. Arenillas, A., Smith, K. M., Drage, T. C. and Snape, C. E. $\mathrm{CO}_{2}$ capture using some fly-ash-derived carbon materials, Fuel. 84 (2005) 2204-2210.

58. San Shwe Hla, D. P., Duffy, G. J., Edwins, J. H., Roberts, D. J., llyushechkin, A., Morpeth, L. D and Nguyen, T. Kinetics of high-temperature water-gas shift reaction over two iron-based commercial catalysts using simulated coalderived syngases, Chemical Engineering Journal. 146 (2009) 148-154.

59. Collin, R. and Graham, J. H. Studies of the role of the copper promoter in the iron oxide/chromia high-temperature water-gas shift catalyst, Physical Chemistry Chemical Physics. 5 (2003) 2719-2723.

60. Keiski, R. L., Tapio Salmi. and Veikko J. P. Development and verification of a simulation model for a nonisothermal water-gas shift reactor, Chemical Engineering Journal. 48 (1992) 17-29.

61. Myer, K. Environmentally conscious fossil energy production, third edition, John Wiley \& Sons, Inc, Hoboken, New Jersey, 2010, ISBN: 978-0-47023301-6.

62. Kato, Y., Harada, N. and Yoshizawa, Y. Kinetic feasibility of a chemical heat pump for heat utilization from high temperature process, Applied Thermal Engineering. 19 (1999) 239-254. 
63. Barker, R. The reactivity of calcium oxide towards carbon dioxide and its use for storage, Journal of Applied Chemistry and Biotechnology. 24 (1974) 221 227.

64. Barker, R. The reversibility of the reaction $\mathrm{CaO}(\mathrm{s})+\mathrm{CO}_{2}(\mathrm{~g}) \leftrightarrow \mathrm{CaCO}_{3}$ (s), Journal of Applied Chemistry and Biotechnology. 23 (1973) 733-742.

65. Zhen-shan, Li., Ning-sheng, C., Yu-yu, H. and Hai-Jin, H. Synthesis, experimental studies, and analysis of a new calcium-based carbon dioxide sorbent. Energy \& Fuels. 19 (2005) 1447-1452.

66. Christina, S. M. and Angeliki, A. L. Parametric study of the $\mathrm{CaO}-\mathrm{Ca}_{12} \mathrm{Al}_{14} \mathrm{O}_{33}$ synthesis with respect to high $\mathrm{CO}_{2}$ sorption capacity and stability on multiple operations. Industrial Engineering and Chemical Research. 47 (2008) 95379543.

67. Zhen-shan, Li., Ning-sheng, C. and Yu-yu, H. Effect of preparation Temperature on cyclic $\mathrm{CO}_{2}$ capture and multiple carbonation-calcination cycles for a new Ca-based $\mathrm{CO}_{2}$ Sorbent. Industrial Engineering and Chemical Research. 45 (2006) 1911-1917.

68. Christina, S. M. and Angeliki, A. L. Development of new $\mathrm{CaO}$ based sorbent materials for $\mathrm{CO}_{2}$ removal at high temperature. Microporous and Mesoporous Materials. 110 (2008) 119-127. 
Water Gas Shift Reaction Catalysis Promoted by Selective Sorption of Carbon Dioxide: Microreactor Experiments

\section{Ramanjaneyulu Katta}

Thesis submitted to the College of Engineering and Mineral Resources at West Virginia University In partial fulfillment of the requirements for the degree of

Master of Science in Chemical Engineering

Department of Chemical Engineering

APPROVAL OF THE EXAMINING COMMITTEE

Todd H. Gardner, Ph.D.

Charter D. Stinespring, Ph.D.

Edwin L. Kugler, Ph.D.

Date

Dady B. Dadyburjor, Ph.D., Chair

John $\mathrm{H}$. 